Citizenship and Democratization in Southeast Asia 


\section{Social, Economic and Political Studies of the Middle East and Asia}

(FOUNDING EDITOR: C. A. O. VAN NIEUWENHUIJZE)

Editor

Dale F. Eickelman

Advisory Board

Fariba Adelkhah (SciencesPo/cE RI, Paris)

Roger Owen (Harvard University)

Armando Salvatore (McGill University)

VOLUME 115

The titles published in this series are listed at brill.com/seps 


\title{
Citizenship and Democratization in Southeast Asia
}

\author{
Edited by \\ Ward Berenschot \\ Henk Schulte Nordholt \\ Laurens Bakker
}

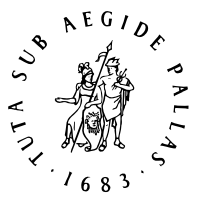

B R I L L

LEIDEN | BOSTON 
This is an open access title distributed under the terms of the CC-BY-NC-ND License, which permits any non-commercial use, and distribution, provided no alterations are OPEN made and the original author(s) and source are credited.

Publication in Open Access was made possible by KITLV (Royal Netherlands Institute of Southeast Asian and Caribbean Studies).

The realization of this publication was made possible by the support of the Royal Dutch Academy of Sciences (KNAW).

Cover illustration: photograph by Matthew Aho.

Library of Congress Cataloging-in-Publication Data

Names: Berenschot, Ward, editor. | Schulte Nordholt, Henk, 1953- editor. |

Bakker, Laurens Gerrit Hendrik, 1974- editor. | Container of (work):

Porio, Emma. Citizen participation and decentralization in the Philippines.

Title: Citizenship and democratization in Southeast Asia / edited by Ward

Berenschot, Henk Schulte Nordholt, Laurens Bakker.

Description: Leiden : Brill, [2017] | Series: Social, economic and political

studies of the Middle East and Asia ; volume 115 | Includes bibliographical references and index.

Identifiers: LCCN 2016040193 (print) | LCCN 2016040744 (ebook) | ISBN

9789004327771 (hardback: alk. paper) | ISBN 9789004329669 (e-book)

Subjects: LCSH: Citizenship--Southeast Asia. | Democratization--Southeast

Asia. | Politics, Practical--Southeast Asia. | Political

participation--Southeast Asia. | Southeast Asia--Politics and government--21st century.

Classification: LCC JQ750.A92 C57 2017 (print) | LCC JQ750.A92 (ebook) | DDC 323.60959--dc23

LC record available at https://lccn.loc.gov/2016040193

Typeface for the Latin, Greek, and Cyrillic scripts: “Brill”. See and download: brill.com/brill-typeface.

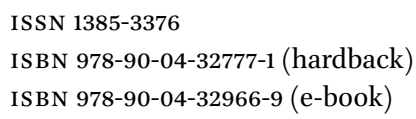

Copyright 2017 by the Editors and Authors.

This work is published by Koninklijke Brill NV. Koninklijke Brill NV incorporates the imprints Brill, Brill Hes \& De Graaf, Brill Nijhoff, Brill Rodopi and Hotei Publishing.

Koninklijke Brill NV reserves the right to protect the publication against unauthorized use and to authorize dissemination by means of offprints, legitimate photocopies, microform editions, reprints, translations, and secondary information sources, such as abstracting and indexing services including databases. Requests for commercial re-use, use of parts of the publication, and/or translations must be addressed to Koninklijke Brill NV.

This book is printed on acid-free paper and produced in a sustainable manner. 


\section{Contents}

About the Authors VII

List of Illustrations XI

1 Introduction: Citizenship and Democratization in

Postcolonial Southeast Asia 1

Ward Berenschot, Henk Schulte Nordholt and Laurens Bakker

\section{PART 1}

Clientelism and Citizenship

2 Citizen Participation and Decentralization in the Philippines 31 Emma Porio

3 Everyday Citizenship in Village Java $5^{1}$

Takeshi Ito

4 Elections and Emerging Citizenship in Cambodia 68 Astrid Norén-Nilsson

5 Sosialisasi, Street Vendors and Citizenship in Yogyakarta 96 Sheri Lynn Gibbings

\section{PART 2}

Identity and Citizenship

6 Militias, Security and Citizenship in Indonesia 125

Laurens Bakker

7 Custom and Citizenship in the Philippine Uplands 155

Oona Paredes

8 Citizenship and Islam in Malaysia and Indonesia $\quad 178$

David Kloos and Ward Berenschot 
PART 3

Middle Classes Engaging the State

9 Digital Media and Malaysia's Electoral Reform Movement 211 Merlyna Lim

10 Citizenship, Rights and Adversarial Legalism in Thailand 238 Wolfram Schaffar

11 Defending Indonesia's Migrant Domestic Workers 265 Mary Austin

12 Yellow vs. Red and the Rise of a New Middle Class in Thailand 289 Apichat Satitniramai

Index 313 


\title{
About the Authors
}

\author{
Mary Austin
}

is a $\mathrm{PhD}$ student at SOAs, researching the campaign for an Indonesian domestic workers' law. She first went to Indonesia in 1980 and relished the opportunity to visit many parts of the archipelago with her husband who was running the British volunteer programme (vso). After a long career as a teacher, school inspector and senior local government officer, Mary returned to study when she retired, completing an MA in gender studies at soAs before embarking on her PhD. When not studying she works as a trustee of Coram, Britain's longest established charity for children.

\section{Laurens Bakker}

is assistant professor at the Department of Anthropology at the University of Amsterdam. His research focuses on land law and land conflict in Southeast Asia as well as on the influence of informal militias in Southeast Asian local politics, society and economy. He received his $\mathrm{PhD}$ in 2009 from the Radboud University Nijmegen with the thesis 'Who Owns the Land? Looking for Law and Power in Reformasi East Kalimantan'. His publications include contributions to a variety of journals and edited volumes, including Critique of Anthropology, The Asia Pacific Journal of Anthropology, and Bijdragen tot de Taal-, Land- en Volkenkunde.

\section{Ward Berenschot}

is a post-doctoral researcher at the Royal Netherlands Institute for Southeast Asian and Caribbean studies (KITLV) where he is currently working on a comparative research project on political clientelism in Indonesia. He holds a PhD in political science from the University of Amsterdam. He is the author of Riot politics: Hindu-Muslim violence and the Indian state (Columbia University Press, 2011) and several articles on ethnic violence, public service delivery and access to justice.

\section{Sheri Lynn Gibbings}

is assistant professor in the Department of Global Studies at Wilfrid Laurier University. She received her PhD from the University of Toronto (2011) and her MA from York University (2004), both in social-cultural anthropology. Her research focuses mainly on urban issues in Indonesia, exploring a number of themes including urban informal economies; urban infrastructures; transformations in post-authoritarian cities; and sovereignty, citizenship, and political 
organization in the city. Her doctoral research examined a governmentorganized relocation of street vendors to a marketplace in Yogyakarta, exploring how a group of traders sought to negotiate their rights in the context of Indonesia's recent transition to democracy. Gibbings is associate editor of City $\&$ Society.

\section{Takeshi Ito}

is associate professor of political science at the Faculty of Liberal Arts and the Graduate School of Global Studies, Sophia University in Tokyo. His research concerns agrarian and environmental change, political economy of development, resource politics, Southeast Asia and theories of hegemony and resistance. He is currently working on a project that critically examines the ways in which neoliberal institutionalism manifested in development practices reshapes and transforms political and social relations of the poor in Indonesia.

\section{David Kloos}

is post-doctoral researcher at the Royal Netherlands Institute of Southeast Asian and Caribbean Studies (KITLV) in Leiden, the Netherlands. He received his $\mathrm{PhD}$ from vu University in Amsterdam for a dissertation on religious practice and authority in Aceh, Indonesia. His current project deals with female Islamic leadership in Malaysia and Indonesia. Recent publications include a volume co-edited with R. Michael Feener and Annemarie Samuels: Islam and the limits of the state: Reconfigurations of practice, community and authority in contemporary Aceh (Brill, 2015).

\section{Merlyna Lim}

is a Canada Research Chair in digital media and global network society with the School of Journalism and Communication, Carleton University. Lim's research interests revolve around societal implications of digital media globally, especially the production, consumption and exchange of information in cyberspace and physical space. Much of her work explores how power relations are embedded in the production of spaces and how people continue to contest, create and expand spaces of participation, engagement and social movements. Prior to joining Carleton University, Merlyna Lim has held positions at Princeton University, Arizona State University and the University of Southern California.

\section{Astrid Norén-Nilsson}

is the author of Cambodia's second kingdom:Nation, imagination and democracy (Cornell University SEAP, 2016). She has published articles in the Journal of 
Southeast Asian Studies, Peace Review: A Journal of Social Justice, and soJourn: Journal of Social Issues in Southeast Asia. She is a political and security analyst for various international concerns. She was a Gates Scholar at the University of Cambridge, where she earned a PhD in Politics and International Studies, and a research fellow at the Royal Netherlands Institute of Southeast Asian and Caribbean Studies (KITLV) in Leiden, the Netherlands. She currently serves as vice-president of the Cambodian Institute for Strategic Studies (CISs), Phnom Penh, Cambodia.

\section{Oona Paredes}

is assistant professor in the Department of Southeast Asian Studies at the National University of Singapore. Her current research focuses on traditions of authority and governmentality in the upland Philippines, with a focus on datuship among the Higaunon Lumads of northern Mindanao. She is the author of A Mountain of difference: The Lumad in early colonial Mindanao (Cornell SEAP, 2013).

\section{Emma Porio}

is professor of sociology and chairperson, Department of Sociology and Anthropology, School of Social Sciences, Ateneo de Manila University, and science research fellow at the Manila Observatory (www.observatory.ph).

\section{Apichat Satitniramai}

received his $\mathrm{PhD}$ in development studies from the University of Wales, Swansea, UK, for his thesis titled 'The Rise and Fall of the Technocrats: The Unholy Trinity of Technocrats, Ruling Elites and Private Bankers and the Genesis of the 1997 Economic Crises'. He currently works as associate professor at the Faculty of Economics, Thammasat University, Bangkok, Thailand. His most recent book, Thai state and economic reform: From the origin of banker's capitalism to the 1997 economic crisis (2013; in Thai), received the Toyota Thailand Foundation Book Award on Social Sciences. His research interests pertain to political economy and politics of development, particularly in Thailand.

\section{Wolfram Schaffar}

is professor for development studies and political science at the University of Vienna. His regional focus is on Southeast and East Asia. Among other places, he has been working at the University of Bonn, Chulalongkorn University in Bangkok, Yangon University in Myanmar and the Royal Netherlands Institute of Southeast Asian and Caribbean Studies (KITLV). His fields of interest are new constitutionalism and democratisation processes, rights and rights-based 
develpment, as well as state theory of the Global South. He is a member of the Association of Critical Social Studies (Assoziation kritische Gesellschaftsfoschung, AkG).

\section{Henk Schulte Nordholt}

is head of research at the Royal Netherlands Institute of Southeast Asian and Caribbean Studies (KITLV) in Leiden, the Netherlands, professor of modern Indonesian history at Leiden University and secretary of the European Association of Southeast Asian Studies (EuroSEAS). He is interested in aspects of modernity in the late colonial period and is finalizing a general history of Southeast Asia. 


\section{List of Illustrations}

Figures

2.1 Political genealogy of local chief executives in Metro Manila 36

2.2 Networks of partner NGOS/POs, business and government in the Urban Renewal Programme in Mandaluyong City 38

2.3 Allied networks of NGOs and community-based organizations (св оs) associated with the mayor's Urban Renewal Programme in Welfareville 39

2.4 Political genealogy of local chief executives in Metro Manila 42

2.5 Pasig Green City Programme and its social map of power sites 45

2.6 Networks of business partners in Pasig City's environmental governance 46

9.1 Number of tweets \#Bersih 1 Jan 2011-30 November 2012, monthly 224

9.2 Global map of Bersih tweets, 28 April 2012, 01:00-7:00 p.m. 225

9.3 Kuala Lumpur, Johor Baru and Penang map of Bersih tweets, 28 April 2012, 01:00-7:00 p.m. $\quad 226$

9.4 Central Kuala Lumpur map of Bersih tweets, 28 April 2012, 01:00-7:00 p.m. $\quad 226$

12.1 Gini coefficients of household income, selected Southeast Asian Countries 296

12.2 Expenditure quintiles 297

\section{Table}

6.1 Overview of ormas community activities and services as observed and reported in Jakarta, East Kalimantan and the Minahasa 129 
978-90-04-32966-9

Downloaded from Brill.com $\odot 4 / 26 / 2023$ 12:50:28PM via free access 


\title{
Introduction: Citizenship and Democratization in Postcolonial Southeast Asia
}

\author{
Ward Berenschot, Henk Schulte Nordholt and Laurens Bakker
}

Paradox. Bemused observers seem to prefer this word to describe the nature of democratization processes across Southeast Asia. From the Philippines (Dressel 2011) to Thailand (Kuhonta 2008) and Indonesia (Hadiz and Robison 2005) commentators are using the word 'paradox' to describe a remarkable similar puzzle. The widening of political and civil rights after the fall of authoritarian regimes in Thailand (1992), Philippines (1986) and Indonesia (1998) (and to some extent Malaysia after the resignation of Prime Minister Mahathir Mohamed in 2003) has on the one hand led to a much livelier public sphere, a freer and more active public debate and an intensified political participation. New protest movements - such as the anti-corruption movements in Indonesia and Malaysia or the Red versus Yellow protests in Thailand - have succeeded in organizing big protests and challenging ruling elites. Moreover, electoral democracy can be termed a success.

Yet on the other hand, the successful institution of free and fair elections seems to have done little to curtail the dominance of oligarchic elites and patronage politics. Throughout Southeast Asia, observers are discerning the development of 'patronage democracies' (Walker 2012; Crouch 2010; Van Klinken 2009; Schulte Nordholt and Van Klinken 2007; Simandjuntak 2010) as 'predatory elites' (Hadiz 2010) are succeeding in winning elections by using either their 'money power' to buy voters or, if that fails, the 'muscle power' of allied criminal elements to coerce them (Aspinall and Van Klinken 2010). In these contests the efforts to woo voters by presenting some sort of policy platform is kept to a minimum, as election speeches are filled with appeals to ethnic identities (Schulte Nordholt 2008, 2011) and promises of preferential access to state resources. Often weakly organized, the activities of political parties are mostly geared towards facilitating clientelistic exchanges between politicians and voters, rather than facilitating public debate or developing programmatic policy agendas (Tomsa and Ufen 2012). Popular representation often seems flawed and 'substantial democratization' remains elusive (Törnquist 2005; Törnquist et al. 2009).

Particularly striking is the relatively little impact that democratic reforms and widening press freedom seem to have on the practice of business elites 
to strike up deals with political elites in order to gain access to lucrative resources - such as government contracts, exclusive concessions to extract natural resources, exclusive import rights, et cetera. This collusion between business, bureaucrats and politicians not only severely weakens legal institutions (Aspinall and Van Klinken 2010) but also leads to a loss of income for Southeast Asian states, higher prices for consumers and increasing income inequalities. Yet citizens are failing to use their newly won democratic freedoms to end such practices. As Jeffrey Winters (2011:156) writes with puzzlement about Indonesia, 'It would not be easy to find another country where so much fabulous wealth could be held by oligarchs who are surrounded by so many millions of people living in so much poverty and frustration, and yet oligarchs face no imminent threats from below and somehow operate economically without the protections of property rights based on the rule of law'.

How can this paradox be explained? Why have democratic reforms in Southeast Asia so rarely enabled citizens to resist or end the predatory and clientelistic practices of their political elites? The persistence of these practices and the 'stalling' (Mietzner 2011) of Southeast Asian democratization processes cannot be attributed solely to institutional shortcomings or selfish behaviour of elites. Instead, there is an urgent need to study these practices 'from below' by studying the ways in which citizenship is being perceived and practiced by ordinary Southeast Asians. This book, therefore, aims to highlight the importance of studying changing forms of citizenship in Southeast Asia in order to understand the particularities of democratization processes in the region.

Citizenship has rarely been a topic in both public and academic debates in Southeast Asia. On the one hand contributions to public debate rarely - or, in our eyes: not often enough - conceptualize the challenges facing Southeast Asian democracies in terms of citizenship. While debates rage on about the nature of democracy, ideal political leadership or the need to raise political moral standards, there is relatively little discussion about what democratic citizenship in present-day Southeast Asia is or should entail. ${ }^{1}$ Conversely, the field of citizenship studies has also paid surprisingly little attention to the forms that

1 For instance, the animated discussions about 'money politics' and corruption generally focus on the lack of moral backbone of political and bureaucratic elites. Similarly, while public discourse in the region displays a lot of nationalistic fervour, there is relatively little discussion on how such patriotic sentiments coincide (and often clash) with attachment to one's ethnic or regional community. While democratic transformations have created more opportunities for the expression of (and mobilization around) various sub-national identities (see Davidson and Henley 2007), a normative debate on the possible tensions between national and ethnic conceptions of the common good occurs only rarely. 
democratic citizenship takes in postcolonial states. As citizenship is generally studied in the context of a liberal, high-capacity welfare state, there has been relatively little attention for the forms of democratic citizenship in the context of a more weakly institutionalized state and a predominantly clientelistic political system. ${ }^{2}$ In these states the rights-claiming, autonomous and individualistic citizen - as celebrated in the general literature on citizenship - might be found, but a focus on this particular type of citizen is hindering a much needed understanding of the very different kinds of state-citizen interactions prevailing in many postcolonial states (Robins 2008; Cornwall et al. 2011).

These interactions should not be studied in terms of their deviation from idealized Western patterns. Rather, we need an understanding of how particular conceptions and practice of rights, reciprocity and representation observable in postcolonial countries, are related to their political economy and particular history of state formation (Chatterjee 2004; Chabal and Daloz 1999; Kaviraj 2001; Mamdani 1996). For example, different interpretations of the 'proper' relation between the ruler and the ruled should not only be related to age-old cultural or religious traditions concerning the nature of political authority (see Anderson 1972; Day 2002), but also to historical processes of (post)colonial state formation and the way political accountability takes shape in the context of a particular political economy. Such an approach will not only increase our understanding of how postcolonial trajectories of state formation are shaping contemporary forms of citizenship, it also requires us to re-examine the normative connotations inherent in our conceptualization of the citizenship ideal.

The patterns of citizenship found in postcolonial states cannot be described merely as a 'cluster of absences' (Isin 2002:130) as they also hint at new, different reformulations of citizenship ideals. As Partha Chatterjee $(2011: 24,205)$ asked, 'Could the accumulation of exceptions justify a redefinition of the norm?' He argues that this accumulation of exceptions poses

...one of the principal tasks of political theory today: to provide a conceptual map of the merging practices of the new political societies of the East. The normative models of Western political theory have, more often than not, only served to show non-Western practices as backward

2 It is, for example, striking how important realities of political life in postcolonial states - such as clientelistic politics and a dependence on patronage channels - receive no mention in overview studies such as the Handbook of Citizenship Studies (Turner and Isin 2002; see also Kivisto and Faist 2007). 
or deviant.....What we need is a different conceptualization of the subject of political practice- neither as abstract and unencumbered individual selves nor as manipulable objects of governmental policy, but rather as concrete selves necessarily acting within multiple networks of collective obligations and solidarities to work out strategies of coping with (resisting, or using to their advantage the vast array of technologies of power deployed by) the modern state.

This reconceptualization of citizenship is, we might add, just as much a task of empirical social science as it is of political theory, as this task requires us to start from everyday state-citizen interactions rather than abstract idealized forms of citizenship. That is the aim of this book. By providing various fascinating first-hand accounts of how citizenship is being practiced and perceived, this book highlights the importance of studying citizenship to understand the unfolding of democratization processes in postcolonial states. Instead of departing from the normative ideal of citizenship, we tried to depart from the practices, values and attitudes that can be observed in everyday interactions between citizens and states. From these concrete interactions can be inferred how citizens interpret and realize, for example, the recognition of their property and identity, their security, or their welfare, we tried to work our way up to identify emerging forms of citizenship in Southeast Asia. By discussing these contemporary observations in the context of long-term historical processes, this book aims to make a contribution towards understanding how particular characteristics of Southeast Asian polities - for example its legal pluralism, relatively weakly institutionalized states, relatively large informal economies - impinge on these forms of citizenship. A second aim of this book is to interpret the ongoing evolution of the forms that citizenship takes in the region. In particular, we highlight three aspects of Southeast Asian democratization processes that, we feel, are generating new forms of citizenship, such as the evolution of clientelistic politics, the changing role of religious and ethnic identities and the particular expansion of the urban middle class.

\section{What is Citizenship?}

The recent popularity of the term citizenship might be partly attributed to its wide range of interpretations. Some interpret citizenship in terms of the realization of rights, such as Hannah Arendt's definition of 'the right to have rights' (Somers 1995). Citizenship then refers to a relationship between a person and a political community, characterized by mutual rights and obligations, and 
activated by the role this person plays in the political life of that community. This relationship is ideally enshrined in law, defining the basic rights of the citizen concerning property, identity, security and welfare and protecting individual citizens against the state as well as against fellow citizens. Others emphasize that citizenship is about the membership of an individual in a political community: '[c]itizenship is passive and active membership of individuals in a nation-state with certain universalistic rights and obligations at a specific level of equality' (Janoski 1998:9).

Charles Tilly (1995:8) provides a more sociological and empirical definition of citizenship as a description of a particular relationship between state institutions and citizens: 'a continuing series of transactions between persons and agents of a given state in which each has enforceable rights and obligations uniquely by virtue of (1) the person's membership in an exclusive category, the native-born plus the naturalized and (2) the agent's relation to the state rather than any other authority the agent may enjoy. Citizenship thus forms a special sort of contract.' According to this definition, it is not just one's formal legal status but rather the character of everyday state-citizen interaction that shapes or curtails one's citizenship. Tilly draws a fairly sharp dividing line between interactions that are and those that are not expressions of citizenship: only when these transactions involve claiming and granting of rights that are enforceable and realized in a manner devoid of personal considerations about, for example, one's wealth, having paid a bribe or being a member of a social class or ethnic group - does the transaction 'count' as an instantiation of citizenship.

These different definitions are indications of the different ways in which citizenship is being studied. While all revolving around the relationship between citizens and the state, three distinct traditions of inquiry can be discerned that all focus on very different aspects of this relationship (Kymlicka and Norman 1994; Pocock 1995; Oldfield 1998; Steward 1995). In a classical study focusing on England, T.S. Marshall (1950) sketched the development of citizenship in three stages as it gradually descended from the elite, to the middle and lower classes. In the eighteenth century individual freedom and property rights were defined for civil elite, in the nineteenth century middle classes obtained the right to participate in politics, while in the twentieth century lower classes were allowed to participate in social democracy and the welfare state. This is the liberal version of citizenship, which emphasizes how this relationship is shaped by the gradual acquisition of individual citizens of rights vis-à-vis state institutions. This focus on the legal status of citizens harks back to the Roman definition of a citizen, namely as someone protected under Roman law from arbitrary prosecution and arrest. Important topics in this tradition are when 
and why citizen rights are extended, as well as the inclusivity of these rights: to which groups of citizens are these rights granted and for what reason? Such questions point to the role of formal citizenship regimes to exclude weaker groups from legal protection and access to state resources, in, for example, highly stratified societies (such as nineteenth century Brazil, see Holston 2008) as well as in countries with large influxes of migrants (Ong, 2006a).

In the republican tradition, citizenship refers to a desirable activity rather than a legal status. In this tradition citizenship involves the willingness and capacity of citizens to take responsibility for the political affairs of their polity. Rather than being just subjects of a state, Aristotle saw human beings as 'political beings' and argued that a man (excluding women) is 'not fully human unless he ruled himself' (Pocock 1995:35). Consequently, this tradition emphasizes not just political rights but also various 'civic' virtues that embody this public spiritness, such as associational activity, public reasonableness, political participation as well as an commitment to the common good. The more survey-oriented literature that stands in this tradition focuses on understanding either the lack or the presence of such civic virtues (Pattie et al. 2004; Putnam 1994). This tradition has a positive emphasis on the role of civil society while too much state interference had to be avoided. In the 1980s, this debate took a new turn when the right to equal access to the Western welfare state was seriously undermined by neo-liberalism which questioned the role of the strong state and advocated instead more space for market forces. 'Less state, more market' became the new recipe for progress, while civil society became a synonym for 'help yourself'.

A third, communitarian tradition emerged in reaction to the first two, emphasizing that citizenship is also an identity, an expression of one's membership in a political community. This identity cannot be universal, as citizens are not just members of a nation but also members of diverse cultural groupings. The existence of different communities with different cultural practices calls for, the adherents of this tradition emphasized, more differentiated forms of citizenship. To accommodate the special needs of minority groups and immigrants, and to prevent the imposition of the lifestyles and preferences of the majority, special provisions would be needed - such as special representation rights, self-government rights or multicultural rights. This tradition thus focuses on citizenship through the lens of managing societal diversity (see Kymlicka and Norman 2000; Hefner 2001).

Citizenship is - in all three interpretations - considered a vital aspect of democratic consolidation. The liberal tradition inspires arguments about the importance of actually realizing civil and political rights, while a communitarian interpretation plays a role in policy-oriented discussions of how to prevent 
social conflict and respect the rights of minorities. The republican tradition has inspired De Tocqueville's famous study of the importance of a lively public sphere for the quality of America's democracy. Along these lines it is regularly emphasized how important the presence of an active and informed citizenry is to strengthen public decision-making and to hold power holders accountable (Holston 2008; Przeworski et al. 1995; Hadenius 2001; Cornwall et al. 2011; Kabeer 2005; Isin and Turner 2002). Scholars have advanced several dimensions of a 'civic culture' as being indispensable for 'making democracy work' such as trust, tolerance, political participation, associational activity and social capital, and a sense of affiliation with national or even global polities (Almond and Verba 1963; Putnam 1994; Pattie et al. 2004). This literature particularly celebrates rights-based collective action - public activities of groups of citizens that convey demands for the actualization or expansion of rights to the state agents - as an important means to achieve democratic accountability. Large cross-national surveys have shown how inhabitants of stable democracies are more likely to value political participation and personal autonomy. This research suggests that democratic institutions do not need to be in place for such 'self-expression values' to emerge (Inglehart and Wetzel 2009), triggering the question, what then does lead to the emergence of such values?

Given this emphasis on the importance of citizenship for democratic consolidation, it is surprising how little attention the field of citizenship studies has paid to the forms that democratic citizenship takes in postcolonial states which is, nowadays, where democratization processes are most prominently visible. Perhaps this was due to the emphasis one of the founders of citizenship studies, Max Weber, put on the uniqueness of Western patterns of statecitizen interaction. He argued that it was the development of northwestern European cities, with their relatively autonomous municipal councils and public militias, that has laid the groundwork for a more egalitarian and rulebased interaction between citizens and power-holders: 'In strong contrast to the medieval and ancient Occident, we never find the phenomenon in the Orient that the autonomy and the participation of the inhabitants in the affairs of local administration would be more strongly developed in the city...than in the countryside.' This relative autonomy of municipal councils in the West was, according to Weber, further strengthened by the superiority of mass-based, disciplined armies in battle. In order to develop such armies at relatively low cost, rulers had to engage in negotiations on a relatively even footing with civilian representatives: "The basis of democratization is everywhere purely military in character; it lies in the rise of disciplined infantry, the hoplites of antiquity, the guild army in the Middle Ages' (Weber 1981:235, 246; quoted in Isin 2002). This focus on the uniqueness of citizenship patterns in northwestern Europe 
subsequently forms the basis for favourable comparisons about the functioning of democracy in the West.

Southeast Asian policymakers have contributed to this tendency by emphasizing the difference of 'Asian values' and traditions. Some might detect such cultural exceptionalism in the ASEAN Human Rights Declaration, adopted in 2012. This human rights charter attracted considerable criticism for stating in Article 6 that 'The enjoyment of human rights and fundamental freedoms must be balanced with the performance of corresponding duties as every person has responsibilities to all other individuals, the community and the society where one lives.' In Article 7 the declaration states that '...the realisation of human rights must be considered in the regional and national context bearing in mind different political, economic, legal, social, cultural, historical and religious backgrounds', and allowing for restriction of all the rights provided on a variety of grounds including national security and public morality (Article 8). Such exceptions - effectively curtailing individual human rights - are more likely to be an indication of conservatism of the drafters rather than cultural difference. International as well as Southeast Asian organizations condemned these exceptions as going against existing international human rights commitments of Southeast Asian governments (Amnesty International 2012).

As a result of this emphasis on the uniqueness of Western experiences, the study of citizenship in postcolonial states needs to overcome a twofold ethnocentric bias. Firstly, there has been relatively little attention for developing the conceptualization of citizenship in ways that are not so intricately linked with Western experiences of state formation. As a result, the temptation is to study citizenship in postcolonial states in terms of a 'cluster of absences' (Isin 2002), that is to focus on the various observable 'deviations' or 'shallowness' of citizenship elsewhere. From this perspective one can observe how actual forms of state-citizen interaction witnessed in countries like Southeast Asia differ greatly from a Western-oriented interpretation of citizenship - think of the importance of local and ethnic affiliations, identity-based and particularistic claim-making, the importance of clientelistic networks in shaping statecitizen interaction and violence against (religious) minorities. Such a focus might lead to the conclusion that patterns of citizenship are so 'deviant' or shallow that the term 'citizenship' would be an unhelpful prism to understand state-citizen interaction in Southeast Asia.

But to follow this path would hinder our understanding of evolving forms of state-citizen interaction as it restricts our analysis to identifying deviations of (idealized) Western patterns of citizenship. Rather, everyday forms of statecitizen interactions should be taken as an opportunity to re-conceptualize our interpretation of citizenship and to develop modes of analysis that are less 
tightly interwoven with Western experiences of state formation. This involves shedding the expectation that citizenship in postcolonial states is 'on its way' to evolving into something more akin to Western patterns. Scholars working in both Africa and Asia have argued that the particular histories of state formation, cultural patterns and the social embeddedness of the market and the state in postcolonial countries conspire to make it unlikely that rights-claiming, autonomous and individualistic citizens - the type celebrated in the literature on citizenship - will emerge in large numbers (Chatterjee 2004; Chabal and Daloz 1999; Kaviraj 2001; Mamdani 1996). We cannot assume that prevalent norms and values underlying conceptions of 'civic behaviour' in postcolonial states will correspond to Western norms. Ideas about proper 'civic' behaviour of citizens and state agents might be shaped by different emphases on, for example, public vs. private concerns, common good vs. group interests, individual vs. collective rights, rights vs. duties, as well as different conceptions of political legitimacy. We need to capture these different attachments to be able to understand the different forms that citizenship may take in Southeast Asia.

Secondly, as the chapters in this book illustrate, in practice many everyday state-citizen interactions are shaped less by rules and laws, but rather by personal relations and norms of reciprocity that provide similar reassurances that state agents will award certain claims. Similarly, the access to important resources (land, education, healthcare, et cetera) is often not acquired by virtue of one's national citizenship, but also by virtue of one's age, gender, ethnicity, membership of a community and other forms of 'local citizenship' (Lund 2011). As Holston (2008:311) argued, 'the processes and practices that define citizenship are inherently disjunctive - not cumulative, linear, or evenly distributed among citizens, but always a mix of progressive and regressive elements'.

Citizenship is mostly studied in the context of high-capacity, liberal welfare states. If one takes, for example, some of the main general publications in the field - such as the Handbook of Citizenship studies (Turner and Isin 2002; see also Kivisto and Faist 2007) - it is striking how little attention is paid to political life in postcolonial states. Words like 'clientelism' or 'patronage' find (almost) no mention and, apart from a few outstanding studies (see for example Mandani 1996; Chabaland and Daloz 1999; Chatterjee 2004; Isin 2002) the field of 'citizenship studies' pays relatively little attention to how the particular historical trajectories and the present-day character of postcolonial states impinge on the norms, attitudes and practices that citizens are adopting vis-à-vis the power holders.

That observation motivated us to produce this book. This volume studies patterns of citizenship in postcolonial Southeast Asia in relation to the particular processes of state formation in Southeast Asia and the weakly institutionalized 
nature of the state. A broader study of citizenship should not only start with everyday patterns of state-citizen interaction (Cornwall 2011; Kabeer 2005), but should also serve to better understand the interaction between the character of postcolonial states and patterns of citizenship.

These considerations led to two workshops, held with the intention of bringing together empirical, well-researched papers on everyday forms of citizenship and its interaction with the nature of the state. One workshop was held at the University of Leiden in December 2012 and the other during the EuroSEAS conference in Lisbon in July 2013. While these papers reflect the complexities and idiosyncrasies across Southeast Asia, they also reflect three important commonalities, which subsequently became the organizing principle for this book. Taken together, these essays advance three key arguments about the forms of citizenship that are emerging across Southeast Asia:

a. Democratization processes are changing - but not eradicating clientelistic exchange relations. The increasingly intense engagement of citizens with their rulers and state is not so much geared towards realizing a universal implementation of rights, but rather towards realizing more inclusive forms of governance.

b. Changing interpretations and expressions of religious and ethnic identities are generating new interpretations of rights and entitlements.

c. Economic growth is generating an expanding urban middle class that is expressing more sensitivities about corruption and governance, while being relatively indifferent towards strengthening political institutions and the rule of law.

These three propositions are taken up in the corresponding three parts of this book. In the remainder of this introduction we will discuss each of these propositions in turn.

\section{State Formation, Clientelism and Citizenship}

Particular trajectories of Southeast Asian state formation are shaping contemporary forms of citizenship. Pre-colonial political dynamics were to a large extent shaped by patron-client relationships and intra-elite competition. Under colonialism clientelism was reproduced but the conditions of patron-client relationships changed. As their position became stronger, because they were now protected by the colonial state, indigenous elites distanced themselves from their clients. Throughout Southeast Asia local aristocracies were used as 
go-betweens in order to establish efficient colonial control with a traditional face. The secret of the success of this system was that the interests of the aristocracy were tied to the needs of the colonial state. Both the backing by and the incentives from a strong colonial centre strengthened the position of local aristocracies who in exchange maintained 'peace and order' and facilitated the mobilization of labour and surplus. Local elites thus became clients of the state, but enhanced their local position as powerful patrons. The way the Dutch in the Indonesian archipelago, the British in Malaysia and the French in Vietnam institutionalized indirect rule helped to create a bifurcated state (cf. Mamdani 1996) as a result of which large parts of the population were subjected to different, customary rule systems upheld by aristocratic or ethnic intermediaries.

Due to this co-option of local elites the colonial state faced little legal or political constraints in its pursuit of profit and order. As a result the state was, for most of its history, experienced not just as an imposed institution, but also as an instrument of oppression. Both regional elites and their subordinated village leaders strengthened their position, while ordinary villagers became more dependent as their bargaining position weakened. A combination of population growth, the ongoing clearance of uncultivated land and state penetration left the population with fewer places to escape oppressive rulers. Yet 'freedom' and equality were on the agenda. The Indonesian word for it, merdeka, referred in the first half of the twentieth century to freedom from traditional loyalties, and, in nationalist discourse, to freedom from taxation, corvée labour and other burdens of the intruding colonial state. Later it evolved into an awareness of equality and the right to have equal access to education, jobs and salaries (Reid 2011).

After independence, new forms of political mobilization characterized the newly emerging nation-states which carried the promise of citizenship and equal rights with them. However, political relationships were to a large extent still clientelistic. In a seminal article on patronage in Southeast Asian politics, James Scott (1972) indicated that patron-client relationships had survived due to the absence of firm impersonal institutions, while inequalities increased because both state institutions and political parties tended to bet on the strong in order to secure mass support. A new phenomenon was that chains of patron-client relations were stretched through political party lines from regional settings towards the national capital.

Since the 1970s, the rise of the strong centralized state characterized Indonesian politics while elsewhere in Southeast Asia state power increased as well. Despite the seemingly hegemonic and bureaucratic appearance of the Indonesian state, in practice a pyramid of patron-client relations ran down from the presidential palace to the villages. These networks were fuelled by 
large sums of money that was distributed in exchange for loyalty (Antlov 1995). This extended network of patronage relationships was hidden behind a façade of elaborate bureaucratic procedures and a carefully orchestrated display of order and unity. At the village level, local elites were incorporated in the patronage network of the state and enabled to enhance their role as local patrons.

The legacy of political interference in bureaucratic processes, the subsequent limited development of bureaucratic autonomy and the coexistence of different legal systems all conspired to curtail the institutionalization of the state; despite the recent wave of democratization in various countries in Southeast Asia, the rule of law and the regulatory capacity of state institutions remain weak. Recent processes of decentralization have further enhanced the capacity of local elites to bend implementation of state policies and laws to their needs (Van Klinken and Barker 2009; Van Klinken and Aspinall 2010). The collusion between politicians, bureaucrats and business has created 'untamed ruling oligarchies' (Winter 2011) and 'predatory elites' (Hadiz 2010), who have been able to manipulate the implementation of state policies to their benefit.

While this illicit cooperation with economic and political elites can be observed in a range of state institutions - from forestry department (McCarthy 2007) to public work departments (Van Klinken and Aspinall 2010) - it is particularly the weakness of the judiciary that is affecting everyday state-citizen interaction. As politicians asserted their control over the functioning of the judiciary, promotion and status within the judiciary is often a product of one's personal contacts and bureaucratic skills, rather than one's knowledge and mastery of the law. The law is often a random and unpredictable force, as personal influence, politics and money is shaping the outcome of legal proceedings just as much as the written law (Lev 2000:305-21; Lindsey and Santosa 2008). Lev (2000:188) has described the prevailing attitude among judges and prosecutors as follows: 'those who talk about rules as if they were absolute are likely to be considered obstructors, stubborn trouble-makers, antisocial fools, or worse'.

As a result, for ordinary, unconnected citizens the formal legal system is something to be avoided rather than an avenue to realize one's rights. For many among, particularly, the poor, legal certainty or the protection of one's rights, is more often attained through alternative authorities such as tribal leaders, local businessmen, regional bosses or strongmen. Clientelist relations with such individuals provide security and support as well as, usually, protection in the case of legal matters. This is particularly important for outsiders with a precarious legal status: for illegal workers and illegal immigrants connections to such patrons provide a measure of security that allows them to engage in economic 
and social activities where official law forbids them to do so. A major downside of such arrangements is that these clientelistic exchanges lead to considerable dependence.

A central theme in the essays in this book is therefore how forms of citizenship develop in interaction with this relatively weakly institutionalized nature of state institutions. The practices and attitudes that citizens adopt vis-à-vis power holders are shaped by pragmatic calculations of how to deal most successfully with state institutions. In the context of weakly institutionalized states, the interaction with state institutions and realization of citizen rights acquires a 'mediated' character (Berenschot 2010, see also McCargo 2011) in the sense that citizens often come to rely on mediation by political and social elites to facilitate their interaction with state institutions and gain access to state resources. As there is little reason to rely solely on formal procedures and rights, citizens face powerful incentives to engage in personal exchange relations that are clientelistic in nature and that stimulate the invocation of solidarity and norms of reciprocity - rather than laws and legal rights - to pressurize authorities to bend the implementation of rules and regulation to one's advantage.

That does not mean that citizen rights are irrelevant. As we will show in several of the contributions in this book, citizens do sometimes invoke a discourse of rights, and efforts of local NGOs activists do sometimes focus on increasing an awareness of rights - see for example Gibbings' chapter on street vendors in Indonesia. Yet what these chapters also illustrate is that the character and use of citizen rights gets transformed because of the weakly institutionalized nature of state institutions and a widespread dependence on (political) intermediaries. In this context the capacity to realize citizen rights is not just, as many civil society-building programmes of development agencies would have it, a matter of raising rights awareness or organizational skills. In the context of weakly institutionalized states, the attitudes associated with ideals of participatory citizenship - such as adopting a rights-claiming and policy-oriented attitude towards the state - often make little sense for citizens who experience that the realization of those rights depends on the cooperation of various political intermediaries. For those citizens expressions of 'civic engagement' are often motivated by the need to maintain or develop relationships with influential political patrons. For example, participation in a protest rally is for some citizens merely an avenue to express (dis-)agreement with government policies, while for others a demonstration is an opportunity to prove allegiance to the political leader who called for the rally. For these latter citizens who need to nurture relations with influential intermediaries in order to access state services, participation in a rally is a favour that can later be cashed in. Similarly, voting can for some citizens simply be the expression 
of a political preference, but for others a vote is an important form of leverage that can be traded in exchange for access to the valuable resources of the state. In terms of a typology found in the literature on civic action: in the context of a weakly institutionalized state, informal brokerage via influential patrons is a much more attractive avenue to advance their interests then more 'civic' forms of engagement like institutionalized petitioning or contentious collective action. ${ }^{3}$ These forms of civic action are simply less effective and thus less attractive than informal brokerage (see De Wit and Berner 2009).

In such a context the terminology that is often used to talk about participatory citizenship is unhelpful as it invokes Western political experiences. For example, the term 'political accountability' is generally associated with the capacity of voters to punish politicians for corruption and inept policymaking. Such an interpretation of accountability implicitly assumes that the electoral support for politicians is based on programmatic considerations: considerations related to the ideology and policy programmes that politicians offer. When the interaction between voters and politicians takes a more clientelistic form, ${ }^{4}$ voters are less inclined to evaluate politicians for their capacity to draft and implement policies. That does not mean that relations between ruler and ruled are not norm-based or undemocratic, but rather that a different form of accountability - clientelistic accountability - takes hold.

Evidence from Southeast Asia (Walker 2012; Crouch 2010; Aspinall 2013; Sidel 2004) as well as elsewhere (Wilkinson 2007; Gay 2006; Krishna 2007; Roniger 2004) is suggesting that democratization processes are making patronclient relations less asymmetrical but not less pervasive. Democratization is improving the bargaining position of clients and their brokers vis-à-vis their political patrons, but democratization does not seem to lead to a reduction of clientelistic practices. This unremitting preference of voters for clientelistic exchanges suggests that political clientelism is not always experienced as a lesser, but rather an alternative form of democratic accountability - a particular exchange relationship between politicians and voters that can be contrasted with programmatic accountability (Kitschelt 2000; Wilkinson and Kitschelt 2007). Politicians are evaluated on the basis of their capacity to solve daily problems and provide a personalized access to state resources. When voters need politicians to facilitate their dealings with state institutions, it matters more whether a candidate is accessible and helpful than whether he is law-abiding and impervious to corruption.

3 For this typology of different forms of 'citizenship practices', see Houtzager 2011.

4 For this distinction between programmatic and clientelistic linkages between politicians and voters, see Kitschelt 2000. 
The terms 'civil society' and 'social movements' evokes similar confusion. It has been common to use these terms to refer to almost all forms of associational activity - ranging from trade unions and business associations to neighbourhood organizations, self-help groups, et cetera - used to pressurize state institutions, voice societal interests and facilitate public debate. Across Southeast Asia there is a sizable civil society that does engage with the state in this manner (Stanley, Priyono and Törnquist 2004). But in the context of weakly institutionalized states the practices and forms of mobilization of particularly poorer citizens do not always take the form of a rights-claiming kind of petitioning of the state, because these forms of association are not open to people who stand in an uncertain and dependent relation to the institutions of the state. The actual civil society, as Chatterjee (2004:66) argues, is 'demographically limited' because 'the poor who mobilize to claim the benefits of various government programmes do not do so as members of civil society...they must succeed in applying the right pressure at the right places in the government machinery [through] the bending and stretching of rules'. As the chapters on, particularly, militias in Indonesia and citizen groups in the Philippines illustrate, many 'social movements' animating state-citizen interaction in Southeast Asia are not so much conduits of 'civic action' but rather operate as facilitators of clientelistic exchanges. Their success in helping their members deal with state institutions is not so much based on organizing formal political participation - demonstrations, petitioning etcetera. Rather, these organizations operate as 'vote-poolers' in the sense that they use the collective vote of their members as a bargaining chip to get politicians to help them.

In a series of publications Partha Chatterjee $(2004,2011)$ proposed to use the term 'political society' next to 'civil society' to capture the different forms of cooperation and association that take place in the realm between the state and the household. 'For the majority of people in postcolonial societies, the normative status of the virtuous citizen will remain infinitely deferred until such time as they can be provided with the basic material and cultural prerequisites of membership of civil society. Until the arrival of that liberal millennium, however, they can only deal with a governmental system with the recourses they can muster in political society' (Chatterjee 2011:206). Chabal and Daloz make a similar argument about the nature of civil society in Africa: 'the state is in fact so poorly institutionalized, so weakly emancipated from society, that there is very little scope for conceptualizing politics in Africa as a contest between a functionally strong state and a homogeneously coherent civil society....it is clear that the business of politics is more usually conducted along informal vertical channels of relations...linking the elites with the rest of the population'. In these contexts the interpretation of citizenship and political participation is 
inseparably linked to the expectation of direct personal benefits that elections can offer (Chabal and Daloz 1999:21; see also Fox 1994).

Clientelistic dependencies on political intermediaries are also shaping the nature of public authority. In the context of a remote and 'mediated' state, the capacity to 'get things done' - that is arranging access to state resources - is an important constitutive element of local leadership and authority. This is strengthened by the way state institutions regularly rely on such local leaders or strongmen to facilitate and mediate the implementation of state institutions, since these institutions often lack the capacity to do so without their intercession. As a result, local non-state authorities do not just represent their people vis-à-vis power holders, they also acquire public authority, in the sense that they acquire the capacity to mediate the implementation of state laws and policies. This reliance of state official intermediaries engenders a fragmentation of state sovereignty. The mediated nature of the state ensures that state officials have to compete with local 'strongmen' and 'bosses' or representatives of ethnic groups over who gets to decide how state regulations will be implemented. Christian Lund (2006) proposed the term 'twilight institutions' to capture this fragmented form of public authority, where non-state actors (such as local strongmen, but also vigilante groups, ethnic associations, et cetera) are acquiring state-like qualities in their capacity to regulate social life and maintain order.

Thus, in short, a weakly institutionalized state and a mediated access to state resources encourage a personal, clientelistic and often identity-based relationship with politicians and other power holders. In this relationship, conceptions of citizen rights are not irrelevant, but do lack a universal character. The realization of rights is contingent on the character of the relationships and everyday personal exchanges through which people live their lives. This is a recurring theme in the essays of this volume: while conceptions of rights and a Western-inspired discourse about citizen participation do inform the way Southeast Asians talk about their interaction with the state and power holders, the realization but also the conceptualization of rights is contingent on the nature of personal networks and attendant norms of reciprocity. Emma Porio, for example, shows how reforms in the Philippines to boost citizen participation and promote 'good governance' ended up being an avenue for local political leaders to co-opt civil society groups and thus strengthen their position. As these groups are made partners in the execution of state functions, they become indebted to these local politicians for bestowed favours. This subsequently makes these organizations convenient campaign tools for politicians. Similarly, Takeshi Ito explains how Indonesia's democratization process has brought a new discourse about citizen participation to Java's villages, but for 
both village elites as well as common villagers that does not mean that everybody needs to have an equal say. Astrid Norén-Nilsson takes security guards in a market in Cambodia as a starting point to argue that the increase of free and open political competition in the immediate aftermath of the 2013 elections created some space for critiquing power holders, but that this space largely depends on how secure people feel in the local, everyday networks through which - in this case - a market is run.

Marginalized groups like these security guards or, to take another example, street vendors still often depend on educated middle-class actors to stake their claims, as Sheri Gibbings discusses in her ethnographic study of a group of street vendors opposing a municipal plan to relocate them. These street vendors felt ignored by the municipal authorities until students and legal aid activists stepped in and succeeded generating pressure by highlighting their plight in the local media. Her article illustrates the reluctance to invoke rights and laws, something which Schaffar also highlights in his contribution: instead of claiming their rights in a direct and open manner, the street vendors' protests focus on the lack of 'sosialisasi' i.e. the lack of inclusiveness in the decision-making process of the municipality.

In that sense these four studies are not observing the kind of 'insurgent citizenship' that Holston witnessed among urban squatters in Brazil. As Holston's urban squatters gradually developed a sense of entitlement, they freed themselves from clientelistic connections, stopped seeing the granting of rights as the granting of a 'privilege' and instead acquired a detailed understanding of Brazil's laws to claim 'text-based rights' to their homes. It is notable that the studies in this book stop short of observing such a shift. Each study emphasizes in its own way that conceptualizations and realization of rights is more likely to take the form of interpersonal obligations and/or a focus on inclusivity and the wish to 'be heard'. What these studies in Part One of this book have in common is that the change they are describing is not necessary an increasing realization of impersonal rights, but rather changing interpretations of the obligations of political elites towards them. These changing interpretations of obligations do not so much entail duties to enforce rights, but rather more open and inclusive forms of ruling.

\section{Identity and Citizenship}

A second striking aspect of democratization processes across Southeast Asia is that the notion of a 'traditional community' has become a cornerstone of political rhetoric that uses modern emancipatory rhetoric of autonomy and 
equal rights (see also Chatterjee 2011:206). That is the central theme of the second part of this book. Claims to land, livelihoods or state services are being made in terms of one's membership of a particular community, whether or religious or ethnic. Ethnic associations and 'sons of the soil' movements have been very successful in using the (ethnic) identity of their members to pressurize government institutions to realize their rights (Davidson and Henley 2007). Through a combination of community organization, vigilantism and the use of (the threat of) violence, such ethnic organizations are gaining an active political presence.

As Laurens Bakker discusses in this volume, the political salience of communal identities should not be seen as a pre-modern attachment to one ethnic or religious community, as it seems a feature of the political landscape generated by a weakly institutionalized state. The emergence and popularity of various ethnic organizations - often referred to as ormas (short for organisasi kemasyarakatan) in Indonesia - can be interpreted as arising out of the need of, in particular, poorer citizens to deal with state institutions by developing reciprocal relations with politicians and influential bureaucrats. As experiences of citizens with the functioning of state institutions offer little reassurance that the invocation of their rights are enough to secure land title or gain access to state resources, particularly poorer citizens face strong incentives to join organizations that strengthen their collective bargaining power. Organizations like the ethnic organisasi kemasyaratan in Indonesia operate as useful lubricants of the clientelistic exchanges between citizens and politicians. While providing politicians with some reassurance that his efforts to deliver resources will translate into votes, these associations enable individual voters to pool their votes and thus to maximize their pressure on power holders. In the terms used above, these organizations do not just mobilize their followers to engage in 'civic action' in order to pressurize state institutions to grant their rights, they also operate in 'political society' as they mobilize their followers to prove their capacity to deliver a large number of votes.

An effect on the reliance on such ethnic associations and vigilante groups to deal with the state, is that membership of local (ethnic) communities gets emphasized as a constitutive element of citizenship, because the everyday mediating functioning of such associations create the impression that the protection of one's livelihood and access to state resources is not just a product of one's right as a citizen, but also a product of one's membership of a cultural community. The sense of belonging is thus layered (Lund 2011): an attachment to the nation-state thus gets mediated through a sense of membership of a cultural community. Note how such a 'layered' form of citizenship contrasts with Western interpretations that emphasize that '[c]itizenship identities 
and citizenship cultures are national identities and national cultures' (Turner 1997:9).

In this context the notion of cultural citizenship has been launched in order to identify politically marginalized groups whose emancipation should be reinforced by applying cultural strategies. Coined by Renato Rosaldo (2003), the term 'cultural citizenship' was initially used to improve the position of Latino immigrants and other marginalized groups in the United States. In Southeast Asia, the term was used to explore the possibilities of marginalized minorities to achieve emancipation through cultural empowerment. Notions of emancipation and distrust towards the state informed to a large extent the dynamics of cultural citizenship. This stands in contrast with earlier phases of nation-building when pluralism was actively discouraged for the sake of national unity. Today, more attention is paid to accommodating ethnic and religious differences within a framework of administrative decentralization, a tendency that is actively supported by an interesting alliance of international financial agencies such as the IMF and the World Bank and critical NGOs. As Oona Paredes discusses in her contribution to this book, in contrast to an earlier emphasis on secession and rebellion, tribal groups like the Higaunon Lumads in the Philippines now adopt an international advocacy discourse of cultural empowerment to resist forced assimilation and marginalization by the central state (see also Tania Murray Li 200o). Lacking much knowledge of the functioning of alien state institutions, the quest of Higaunon for fuller forms of citizenship is changing local forms of leadership as indigenous people come to depend on new intermediaries who understand - more or less - how to deal with these alien state institutions. In the process Higaunons face pressures to shed their cultural distinctiveness to confirm to established notions of 'Filipino-ness'. This leads Paredes to argue that the status and position of the Higaunon within Philippine society will depend on whether they succeed in challenging and changing the state's own cultural construct of citizenship.

This emphasis on community is not just changing interpretations of who has access to rights, but is also impacting the very interpretation of what citizenship entails. Particularly the intensification of religious fervour and the increased importance of religion in public debates across Southeast Asia is having profound impact on the nature and interpretation of citizenship. In studies of citizenship in Western Europe, citizenship is sometimes described as a form of 'civil religion' that binds citizens together in the absence of a widely shared religious value system. As Kloos and Berenschot discuss in their contribution, rather than replacing religion, in Southeast Asia the interpretation and practice of citizenship is closely tied to religious interpretations and practices. Religion is far from being in decline in Southeast Asia. Across Southeast 
Asia, public expressions of religious piety have become more pronounced be it Islamic piety in Malaysia or Indonesia (Hefner 2011), Christian piety in the Philippines or Buddhist piety in Thailand or Myanmar. In both the Philippines and Indonesia religious organizations played an important role in the opposition to authoritarian rule (Hedman 2001). Furthermore, religion forms a cornerstone of public debate, as references to religious injunctions are a common and accepted way to argue about policies and laws. The secular nature of the state - in the sense of establishing the non-religious character of the state - has become a hotly debated topic, not only in Malaysia. Kloos and Berenschot discuss how intense debates are being waged about whether the state should play a bigger role in enforcing religious morality - in ways that are often at odds with interpretations of citizenship that emphasize the need to protect the private sphere from public interference. In these various ways the nature of citizenship in Southeast Asia is closely tied up with the evolution of religious thought. The nature of citizenship in these countries - for example the relative emphasis on rights versus duties and the protection of a private sphere - will be profoundly affected by the ongoing shift in attitudes toward religious truths.

\section{Economic Growth and Emerging Middle Classes}

The third part of this book is devoted to the puzzling role of Southeast Asian middle classes as a reluctant engine of democratization. While economic growth is enlarging an urban, formally employed middle class, this emerging middle class has a mixed record when it comes to protecting democracy or expanding citizen rights. The growth of independent middle classes was important to generate pressures to establish democracy in countries like the Philippines, Thailand or Indonesia - and in that sense Barrington Moore's famous claim of 'no bourgeoisie, no democracy' arguably still holds (see Sidel 2008). Yet these middle classes have played a much more reluctant role when it comes to a subsequent deepening of democracy. They are focusing their political engagement more on problems of corruption and governance, and less on strengthening the rule of law or the advancement of citizen rights. True, this emerging middle class has become the driver of various anti-corruption movements across Asia. Anna Hazare's movement in India, the Cinta KPK movement in Indonesia as well as Malaysia's Bersih movement can all be seen as evidence of a growing impatience of the middle class with 'politics as usual' and the way corruption has infused much state-citizen interactions. These protests are often fuelled by the online activism of (young) voters. As Lim 
discusses in this volume, protests for electoral reform on Malaysia's streets as well as online activism are creating new pressures on Malaysian politicians to shed clientelistic practices and improve accountability. She discusses a key aspect of changing state-citizen relations across Southeast Asia: social media are enabling political activists to build mass support and put pressure on power holders, a development that is shifting the power balance between citizens and the state. At the same time Lim emphasizes that these technologies are no 'magic want' as successful digital activism depends on the presence of 'offline' civil society networks and organizations.

Yet the studies in this volume suggest that it remains to be seen whether these protests amount to more than a desire to punish corrupt officials and whether these protests signal a genuine commitment to strengthen the rule of law. In his contribution Wolfram Schaffar shows how citizen participation is often not about entrenching or broadening citizen rights. Focusing on AIDS activism in Thailand, he makes the important observation that this kind of citizen engagement with the state is marked by a reluctance to claim one's rights via the judicial system. Instead, Schaffar argues that much citizen activism focuses on inclusivity of legislative processes - a theme that also came up in the first part of the book. Similarly, support for the push of Jakarta-based NG Os that Mary Austin describes seems to stem as much from a sense of nationalism as from a commitment to defend the rights of domestic workers: this movement focuses on abuses abroad, sidestepping the thorny issue of the similarly common abuses that Indonesians themselves commits towards their domestic workers. Yet her contribution, as well as Schaffar's, illustrate the real impact that civil society organizations are having on policy making. Austin shows the considerable responsiveness of the Indonesian state to well-organised civil society campaigns on broadly supported topics like the plight of domestic workers abroad.

In many ways the middle class is often co-opted by the state. The very groups that make up these emerging middle classes - government officials, business men, traders, factory owners, shop owners, et cetera - do in various ways benefit from their privileged access to influential bureaucrats and politicians, in the sense that the strength of their social networks is generating various benefits - a business license, a government contract, a career opportunity that they might not have had if official regulations where implemented in a less personalized manner (see Hedman 2006; Van Klinken and Berenschot 2014). The wish for 'clean government' might, therefore, be mostly about punishing overly greedy officials rather than democratising a system from which many members of the middle class are benefiting. Middle class citizens benefit from their privileged and personalized access to power holders which enables 
them to, for example, bypass minimum wage regulation, minimize competition and curtail labour unrest - areas where poorer citizens or emerging lower middle classes could benefit from a stricter implementation of state regulation.

There is, thus, something hypocritical in the disdain of middle class citizens for the kind of clientelistic politics that lower classes need to defend their livelihoods. While the middle classes have been able to benefit from the opportunities that Asia's globalized economies have offered, the lower classes have had to contend with relentless pressures to reduce labour costs, resulting in deteriorated labour conditions, pressure on wages and less secure and less formalized livelihoods, while they often lack the contacts and organizational skills to address these problems. These insecurities and limited mobilizational capacities make poorer citizens more vulnerable and more dependent on the favours and personalized access to state resources that politicians provide precisely the type of politics that middle classes decry.

Aihwa Ong already pointed to the way in which neo-liberal economic policies are generating different citizenship regimes within one country. Ong (2006b:50o) focuses particularly to the way in which the policies of Asian states to attract cheap labour is creating different bundles of citizenship rights: 'the embrace of self-enterprising values has made citizenship rights and benefits contingent upon individual market performance.... Instead of all citizens enjoying a unified bundle of citizenship rights, we have a shifting political landscape in which heterogeneous populations claim diverse rights and benefits associated with citizenship' These arguments underline the need to develop an analysis of citizenship that is sensitive to class differences as well as possible rural-urban divides (cf. Mamdani 1996). An example can be found in Apichat Satitniramai's analysis of the Yellow versus Red struggle in Thailand in this volume. The complaints about corruption of Bangkok's middle class turn out to be more about defending their own privileged access to the state rather than a genuine desire to discipline state institutions. Apichat Satitniramai argues that the Yellow movement partly stems from the rise of a new, more rural middle class which is threatening the interests of Bangkok's middle class - a threat that stimulated large parts of Bangkok's educated urbanites to participate in rallies that called for the annulment of elections and the curtailment of democratic freedoms.

The recent clashes between the 'Red Shirts' and 'Yellow Shirts' in Thailand might just be a foreboding of the kind of conflicts that such differentiated forms of citizenship can generate. Opinion polls suggest that voting behaviour during Indonesia's recent presidential elections displayed a somewhat similar class-based pattern: support for the autocratic New Order general Prabowo Subianto was greatest among the urban middle class, while Joko Widodo - the 
first presidential candidate who did not belong to the old New Order elite - got more support among the rural poor (see Mietzner 2014:115).

Such observations suggest that a class-based differentiation of citizenship will take political centre stage in the coming years. As social inequalities are still widening, it is likely that the experience and practice of citizenship will remain highly differentiated. The three salient characteristics of emerging forms of citizenship in Southeast Asia highlighted in this book - the changing but not abating pervasiveness of clientelistic exchange relations, the importance of religious and ethnic identities in shaping new interpretations of rights and entitlements, and the relative indifference of the middle class towards strengthening political institutions and the rule of law - all suggest that pervasive social and political inequalities will continue to mark the nature of citizenship in Southeast Asia. Yet the essays in this book also offer some hope that democratization processes are generating more inclusive forms of citizenship. Maybe everyday citizenship struggles are not always framed in terms of realizing and broadening citizen rights - the weakly institutionalized nature of most Southeast Asian states is discouraging such an approach - but these struggles do indicate that interpretations of citizens of the obligations of power holders and political elites towards them are changing. These changing interpretations of obligations are not always formulated in the language of rights, but do entail more open and inclusive forms of ruling. The emphasis of the contestations discussed in this book on inclusivity, participation and openness suggests that Southeast Asian states and their rulers will have to adapt to new and evolving interpretations of what citizenship should entail.

\section{References}

Almond, G., \& Verba, S. (1963). The civic culture: political attitudes and democracy in five nations. Princeton: Princeton University Press.

Amnesty International (2012). Civil society rejects flawed ASEAN Human Rights Declaration. Available at http://www.amnesty.org/en/library/asset/IOR64/o05/2012/en/ cd2af858-753e-477a-9bad-9b9d863dd3bd/ior640052012en.html

Anderson, B. (1972). The Idea of Power in Javanese Culture. In Holt C. (Ed.), Culture and Politics in Indonesia. Ithaca: Cornell University Press.

Antlov, H. (1995). Exemplary centre, administrative periphery: rural leadership and the new order in Java. Richmond: Curzon Press.

Aspinall, E. \& van Klinken, G. (2010). The State and Illegality in Indonesia. Leiden: KITLV Press. 
Berenschot, W. (2010). Everyday mediation: The politics of public service delivery in Gujarat, India. Development and Change, 41(5), 883-905.

Chabal, P. (1999). Africa works : disorder as political instrument. Bloomington: Indiana University Press.

Chatterjee, P. (2004). The Politics of the Governed: Reflections on Popular Politics in Most of the World. New York: Columbia University Press.

Chatterjee, P. (2011). Lineages of political society: Studies in postcolonial democracy: Columbia University Press.

Cornwall, A., Robbins, S., \& Lieres, B.v. (2011). States of Citizenship: Context and Cultures of Public Engagement and Citizen Action. IDS Working Paper Series, 2011(363).

Crouch, H. (2010). Political Reform in Indonesia after Soeharto. Singapore: ISEAS.

Davidson, J., \& Henley, D. (2007). The revival of tradition in Indonesian politics: The deployment of adat from colonialism to indigenism (Vol. 5): Taylor \& Francis.

Day, T. (2002). Fluid iron : state formation in Southeast Asia. Honolulu: University of Hawai'i Press.

De Wit, J., \& Berner, E. (2009). Progressive patronage? Municipalities, NGOs, CBOs and the limits to slum dwellers' empowerment. Development and Change, 4o(5), 927-947.

Dressel, B. (2011). The Philippines: how much real democracy? International Political Science Review, 32(5), 529-545. doi: 10.1177/0192512111417912.

Fox, Jonathan. (1994). The Difficult Transition from Clientelism to Citizenship: Lessons from Mexico. World Politics, 46(2), 151-184.

Gay, R. (2006). The even more difficult transition from clientelism to citizenship: lessons from Brazil. In Fernández-Kelly P. \& J. Shefner (Eds.), Out of the shadows : political action and informal economy in Latin America. University Park: Pennsylvania State University Press.

Hadenius, A. (2001). Institutions and Democratic Citizenship. Oxford: Oxford University Press.

Hadiz, V. (2010). Localising Power in Post-Authoritarian Indonesia: A Southeast Asia Perspective. Stanford: Stanford University Press.

Hadiz, V., \& Robison, R. (2005). Neo-Liberal reforms and illiberal consolidations: The Indonesian paradox. The Journal of Development Studies, 41(2), 220-241.

Hedman, E. (2001). Contesting state and civil society: Southeast Asian trajectories. Modern Asian Studies, 35(4), 921-951.

Hedman, E. (2006). In the name of civil society: from free election movements to people power in the Philippines: University of Hawaii Press.

Hefner, R. (2001). The politics of multiculturalism: Pluralism and citizenship in Malaysia, Singapore, and Indonesia: University of Hawaii Press.

Hefner, R. (2011). Civil Islam: Muslims and Democratization in Indonesia: Princeton University Press. 
Holston, J. (2008). Insurgent Citizenship: Disjunctions of Democracy and Modernity in Brazil. Princeton: Princeton University Press.

Houtzager, P., \& Acharya, A. (2011). Associations, active citizenship, and the quality of democracy in Brazil and Mexico. Theory and Society, 4o(1), 1-36.

Isin, E., \& Nielsen, G. (Eds.). (2008). Acts of Citizenship. New York: Zed Books.

Isin, E., \& Turner, B. (2002). Handbook of Citizenship Studies. London: Sage.

Janoski, T. (1998). Citizenship and Civil Society: A Framework of Rights \& Obligations in Liberal, Traditional, and Social Democratic Regimes. Cambridge: Cambridge University Press.

Kabeer, N. (2005). Inclusive citizenship: Meanings and expressions (Vol. 1): Zed Books.

Kaviraj, S. (2001). In Search of Civil Society. In S. Kaviraj \& S. Khilnani (Eds.), Civil Society: History and Possibilities (pp. 287-324). Cambridge: Cambridge University Press.

Kitschelt, H. (2000). Linkages between Citizens and Politicians in Democratic Polities. Comparative Political Studies, 33(6-7), 845-879. doi: 10.1177/001041400003300607.

Kitschelt, H., \& Wilkinson, S. (2007). Citizen-politician linkages: an introduction. In H. Kitschelt \& S. Wilkinson (Eds.), Patrons, Clients and Policies: Patterns of Democratic Accountability and Political Competition (pp. 1-50). Cambridge: Cambridge University Press.

Kivisto, P., \& Faist, T. (2007). Citizenship: Discourse, Theory, and Transnational Prospects. Malden: Blackwell.

Klinken, G.v. (2007). Communal Violence and Democratization in Indonesia: Small Town Wars. New York: Routledge.

Klinken, G.v. (2009). Patronage Democracy in Provincial Indonesia. In Törnquist O., Webster N. \& Stokke K. (Eds.), Rethinking Popular Representation. New York: Palgrave Macmillan.

Klinken, G.v., \& Aspinall, E.. (2010). Building relations: Corruption, competition and cooperation in the construction industry. In E. Aspinall \& G.v. Klinken (Eds.), The State and Illegality in Indonesia. Leiden: KITLV Press.

Klinken, G.v., \& Barker, J. (Eds.). (2009). State of authority : the state in society in Indonesia. Ithaca: Cornell University Press.

Klinken, G.v., \& Berenschot, W. (Eds.). (2014). In Search of Middle Indonesia. Leiden: Brill.

Krishna, A. (2007). Politics in the middle: mediating relationships between the citizens and the state in rural North India. In H. Kitschelt \& S. Wilkinson (Eds.), Patrons, Clients and Policies: Patterns of Democratic Accountability and Political Competition (pp. 141-159). Cambridge: Cambridge University Press.

Kuhonta, E. (2008). The Paradox of Thailand's 1997 "People's Constitution": Be Careful What You Wish For. Asian Survey, 48(3), 373-392.

Kymlicka, W., \& Norman, W. (1994). Return of the Citizen: A Survey of Recent Work on Citizenship Theory. Ethics, 104(2), 352-381. 
Kymlicka, W., \& Norman, W. (200o). Citizenship in culturally diverse societies: issues, contexts, concepts. Citizenship in diverse societies, $1-41$.

Lev, D. (2000).LegalEvolution and PoliticalAuthority in Indonesia, SelectedEssays (Vol.4): Martinus Nijhoff Publishers.

Lindsey, T., \& Santosa, M.A. (2008). The trajectory of law reform in Indonesia: a short overview of legal systems and change in Indonesia. Indonesia: law and society, and edn. The Federation Press, Singapore.

Lund, C. (2006). Twilight institutions: public authority and local politics in Africa. Development and Change, 37(4), 685-705.

Lund, C. (2011). Land rights and citizenship in Africa. Nordiska Afrikainstitutet. Discussion Papers(65).

Mamdani, M. (1996). Citizen and Subject: Contemporary Africa and the Legacy of Late Colonialism. Princeton: Princeton University Press.

McCargo, D. (2011). Informal Citizens. Graduated citizenship in Southern Thailand. Ethnic and Racial Studies 34 (5), 1-17.

McCarthy, J. (2007). Sold down the river; renegotiating public power over nature in Central Kalimantan. In H.S. Nordholt \& G.v. Klinken (Eds.), Renegotiating Boundaries: Local Politics in Post-Suharto Indonesia. Leiden: KITLV Press.

Mietzner, M. (2011). Indonesia's democratic stagnation: anti-reformist elites and resilient civil society. Democratization, 1-21.

Mietzner, M. (2014). Indonesia's 2014 Elections: How Jokowi Won and Democracy Survived. Journal of Demcoracy, 25(4), 111-125.

Murray Li, T. (2000). Articulating indigenous identity in Indonesia: Resource politics and the tribal slot. Comparative studies in society and history, 42(01), 149-179.

Nordholt, H.S. (2008). Identity Politics, Citizenship and the Soft State in Indonesia: an Essay. Journal of Indonesian Social Sciences and Humanities 1(1), 1-21.

Nordholt, H.S. (2011). Decentralization and Democracy in Indonesia: Strengthening Citizenship or Regional Elites? In Robison D. (Ed.), Handbook of Southeast Asian Politics. Oxford: Routledge.

Nordholt, H.S. \& Klinken, G.v. (Eds.). (2007). Renegotiating Boundaries: Local Politics in post-Suharto Indonesia. Leiden: KITLV Press.

Oldfield, A. (1998). Citizenship and Community: Civic Republicanism and the Modern World. In Shafir G. (Ed.), The Citizenship Debates (pp. 75-93). Minneapolis: University of Minnesote Press.

Ong, A. (2006a). Mutations in citizenship. Theory, Culture \& Society, 23(2-3), 499-505.

Ong, A. (2006b). Neoliberalism as exception: Mutations in citizenship and sovereignty.

Pattie, C. (2004). Citizenship in Britain: Values, participation and democracy: Cambridge University Press.

Pocock, J. (1995). The ideal of citizenship since classical times. Theorizing citizenship, 31. 
Przeworkski, A. (1995). Sustainable Democracy. Cambridge: Cambridge University Press.

Putnam, R. (1994). Making democracy work : civic traditions in modern Italy. Princeton: Princeton University Press.

Reid, A., To Nation by Revolution. Singapore: NUS Press.

Robins, S., Cornwall, A., \& von Lieres, B. (2008). Rethinking 'Citizenship' in the Postcolony. Third World Quarterly, 29(6), 1069-1086.

Roniger, L. (2004). Political Clientelism, Democracy, and Market Economy. Comparative Politics, 36(3), 353-375.

Rosaldo, R. (2003). Cultural citizenship in island Southeast Asia nation and belonging in the hinterlands: University of California Pr.

Scott, J. (1972). Patron-client politics and political change in Southeast Asia. The American Political Science Review, 66(1), 91-113.

Sidel, J. (2004). Bossism and democracy in the Philippines, Thailand, and Indonesia: towards an alternative framework for the study of 'local strongmen'. In Harriss J., Stokke, Kristin and Tornquist, Olle (Ed.), Politicising democracy: the new local politics of democratisation (pp. 51-74). Basingstoke: Palgrave Macmillan.

Sidel, J. (2008). Social origins of dictatorship and democracy revisited: colonial state and Chinese immigrant in the making of modern Southeast Asia. Comparative Politics, 14(4), 127-147.

Simanjuntak, D. (2010). Who shall be raja? : patronage democracy in North Sumatra, Indonesia Unpublished PhD dissertation, University of Amsterdam.

Somers, Margaret R. (1995). Narrating and Naturalizing Civil Society and Citizenship Theory: The Place of Political Culture and the Public Sphere. Sociological Theory, 13(3), 229-274.

Stanley, P., Priyono, A.E. and Törnquist, O. (eds.) (2004) Indonesia's Post-Soeharto Democracy Movement. Jakarta: Demos.

Stevenson, N. (2001). Culture and citizenship. London: Sage.

Stewart, A. (1995). Two Conceptions of Citizenship. The British Journal of Sociology, $46(1), 63-78$.

Tilly, C. (1995). Citizenship, Identity and Social History. International Review of Social History, 4o(SupplementS3), 1-17. doi: doi:10.1017/Soo20859000113586.

Tomsa, D., \& Ufen, A. (2012). Party politics in Southeast Asia: clientelism and electoral competition in Indonesia, Thailand and the Philippines (Vol. 55): Routledge.

Törnquist, O. (2005) 'The Political Deficit of Substantial Democratisation', in Harriss J., Stoke K. \& Törnquist O. (Eds.) Politicising Democracy: the New Politics of Democratisation, pp. 201-225. Basingstoke: Palgrave Macmillan.

Törnquist, O., Stokke, K. and Webster, N. (2009) Rethinking popular representation: Palgrave Macmillan.

Turner, B. (1997). Citizenship studies: A general theory. Citizenship Studies, 1(1), 5-18. 
Walker, A. (2012). Thailand's political peasants: Power in the modern rural economy. Wisconsin: University of Wisconsin Press.

Wilkinson, S. (2007). Explaining changing patterns of party-voter linkages in India. In Kitschelt H. \& Wilkinson S.I. (Eds.), Patrons, Clients and Policies: Patterns of Democratic Accountability and Political Competition (pp. 110-141). Cambridge: Cambridge University Press.

Winters, J. (2011). Oligarchy: Cambridge University Press. 
PART 1

Clientelism and Citizenship 
978-90-04-32966-9

Downloaded from Brill.com $\odot 4 / 26 / 2023$ 12:50:28PM via free access 


\title{
Citizen Participation and Decentralization in the Philippines
}

\author{
Emma Porio
}

Since the early 1990s, democratization and decentralization have radically changed the functioning of both national and local governments in the Philippines. The Local Government Code of 1992, for instance, reassigned functions and powers that were previously under national agencies to local government units (LGUs). Furthermore, the 1992 Urban and Housing Development Act transferred housing, social services and land use functions to local governments, in attempts to curb the growth of informal settlements and poverty. In addition to this, constitutional and legal reforms have led to a national 'citizen charter' which has enabled citizens and citizen groups to complain to officials whenever the delivery of public services is inadequate. Therefore, the 1989 Constitution gave civil society a more prominent role in policy development.

As a result of these changes, some observers argue that citizens have become more actively engaged with the performance of (local) governments (see, for example, Guevarra 2004; Holmes 2011; Porio 2012, 2014). However, while most studies have hailed this increased citizen participation as a boost for the performance of local governments, some have argued that decentralization has also led to the further entrenchment of traditional elites and their local allies (Rocamora 2003). After twenty years of local governance reforms, and with increased citizen participation through NGOs, community-based organizations (Своs) and people's organizations (POs), many civil society leaders and reform advocates in the Philippines find themselves questioning the prevalence of such predatory and clientelistic practices of the political elites.

Previous studies have argued that the weak institutional apparatus of the Philippine state is responsible for this entrenchment of elite politics (e.g. Rocamora 2003) and further reinforced by the absence of strong political parties (Rivera 2011). These institutional arguments can partly account for the dominance of political-economic elites in local politics. Yet I expand this argument further and state that the mobilization and participation of civil society groups is actually helping local elites to strengthen their dominance. I stress that the new emphasis on citizen participation and accountability has not led to the redistribution of power; on the contrary, the emphasis on civil society participation has actually offered new avenues for 'dynastic' local families to 
develop and nurture local support, further cementing their powerful positions. Unlike earlier political elites, the current breed of politicians have engaged various segments of civil society and the private sector in their implementation of government programmes. In this process, mayors and government officials construct a seemingly accountable, participatory and empowered governance structure by forging collaborative partnerships with civil society organizations and the private sector, while in fact they are reinforcing their political dominance as, in actuality, these partnerships can weaken civil society.

This is done through what I call 'networked governance practices' - the practice of incorporating civil society organizations by giving them a role in city governance (and thus access to budgets of local government units (LGUS)) in exchange for political support during elections. Unlike the earlier centralized period, the above-mentioned governance reforms open up spaces for local chief executives to create legitimate networks and alliances with civil society organizations and the private sector, so that they engage in implementing their priority programmes. Through these mechanisms, the power of the local chief executive (including that of his family and allied social, political and economic networks) is socially produced and reinforced in governance structures and practices.

\section{Democratization and Decentralization}

The decentralization of state power from national to local governments was instituted to increase the efficiency and effectiveness of LGUs in responding to the needs of their constituents. In the Philippines, decentralization ensued alongside the push for democratization of state - civil society relationships, which was given a big boost in the 1986 People Power Revolution (Porio 2002). People Power presumably dismantled the twenty-year Marcos dictatorship, starting with a declaration of martial law in 1972. The push for the decentralization - democratization nexus in urban development became further institutionalized by the Social Reform Agenda (SRA) of the Ramos Administration (1992-1998). The SRA became the centrepiece for institutionalising democratic practices, such as the consultation and participation of marginalized groups and other sectors, in local - national governance processes.

The Citizens Charter, ${ }^{1}$ the main framework for citizen engagement, describes the service standards that citizens can expect from government officials. It provides step-by-step instructions to avail a particular service (for example,

1 Off-shoot of the RA 9485 or the 2007 Anti-Red Tape Law. 
how to obtain birth, death, business and work certificates, or business processing and licensing services) as well as a guarantee of the expected performance level. This aims to reduce resource leakages or corruption and increase inclusiveness in the delivery of social services to the LGUs constituencies, especially those from the marginal groups. Decentralization has resulted in the LGUS gaining more control over state resources, and the allocation/distribution of these public goods, such as the Internal Revenue Allotment (IRA) of LGUS or the income from property taxes, have often become patronage goods that politicians and parties can use to reward or attract supporters.

Researchers have given decentralization and democratization policies mixed reviews. Several authors have sought to highlight their innovations, accomplishments and successes, such as Holmes (2011) and Guevara (2004), whereas others have argued that decentralization has not successfully eliminated the problems of corruption, nor the dominance of political elites and their clientelistic strategies (see Langran 2011; Leviste 2004; Rivera 2011; Rood 1998). These authors have argued that decentralization has given much greater autonomy and control to local chief executives, which can sometimes compromise the delivery of basic services as well as reproduce local patronage structures. But others (such as Karaos 1997) have argued that these reforms have expanded the autonomy and participation of citizen groups or civil society in both national and local governance.

My argument is partly at odds with this assessment, and I stress that the current emphasis on democratic governance is actually strengthening their dominance of the local political. Their 'networked governance strategies' enable political elites to present themselves as implementing democratic reforms, whilst also building their electoral support. They selectively strengthen traditional political elites and allied power bases in civil society and the business sector by granting them a role in the provision and organization of public services. Ironically, these clientelistic practices are legitimized within a discourse emphasizing the importance of civil society and democracy in crafting development trajectories. In this process, these exchanges strengthen political elites in power and their allied partners in civil society and the private sector, while eroding the influence of competing political patrons in the city. This emerging pattern in decentralized governance also raises the contradictory tendencies of civil society participation in local governance - that of broadening citizenship bases while, at the same time, narrowing and strengthening certain lines of participation and reinforcing/consolidating the power bases of the ruling political elite.

I will illustrate these arguments by examining the implementation of environmental programmes in Pasig City and the urban renewal programme in Mandaluyong City, which are two of the richest areas of Manila (Virola 2010). 
As mentioned by Holmes (2011), these two cities have been awarded the Galing Pook Awards for excellence in local governance.

\section{A Case Study: Mandaluyong City's Urban Renewal Programme for Welfareville}

Metro Manila, or the national capital region (NCR), is the political, sociocultural and economic centre of the country and often referred as 'Imperial Manila' by political leaders outside of it. Accounting for over one-third (38\%) of the nation's gross domestic product (GDP) and being the seat of political power, this label is not entirely misplaced. ${ }^{2}$ However, economic growth and investments in basic services and infrastructure have not kept abreast with the expanding needs of the population. ${ }^{3}$ Decentralization of urban governance and management, then, becomes a critical factor in how local government units (LGUs) can provide basic services, stimulate the economy and generate employment for its constituencies (Porio 2009; NCSB 2010).

Metro Manila comprises seventeen administrative cities, each having relatively autonomous local government units (LGUs), but is loosely connected through the Metro Manila Development Authority (MMDA), which takes care of traffic, waste management and flood control functions. Pasig and Mandaluyong are two of them. Urban renewal, disaster management, population control, delivery of services, health, sanitation and environmental functions are the responsibility of the LGUs, but also constitute a major challenge for the metropolis. With the devolution of these functions, local chief executives (LCE) or mayors have executive, legislative and judicial control over local officials, government employees and their political constituencies.

Mandaluyong City has a total population of 328,700 , spread across twentyseven barangays ${ }^{4}$ (NSCB 2010) and is one of the top fastest growing cities in Metro Manila. Located at the geographical centre of the metropolis, Mandaluyong is bordered by the country's capital in the West, San Juan City (North),

2 With a population of 12.5 million in an area of 686 square kilometres, Metro Manila is highly congested at 18,650 residents per square kilometre With only 3.5 million in 1970, the city's population expanded almost four times over the past forty years and is projected to reach twenty-five million in 2020.

3 While Metro Manila's poverty incidence is lower (11\%) compared to the national figure $(33 \%)$, one in every ten residents live in slum and squatter settlements (Ballesteros 2010) and about $60 \%$ do not have adequate basic services.

4 Lowest political-administrative unit of the Philippine government. 
Quezon City and Pasig City (East) and by Makati City (South). It hosts the huge commercial complex of the Ortigas Center, the Asian Development Bank (АDB) and the Philippine office of the World Bank and other UN agencies. While it has only a $2.5 \%$ poverty incidence, it houses one of the most congested informal settlements in Manila - the Welfareville community. This sees 23,000 informal settler families (about 161,00o people with 55,000 registered voters) all crammed into a twenty hectare lot. Aside from being highly congested, a large segment of the population does not have adequate access to potable water, sanitation facilities and jobs/livelihoods. A sizeable portion of the community also gets flooded during rainy seasons as they do not have adequate drainage systems, especially those living near the creeks and danger zones.

Although enacted in 2007, the Citizen's Charters of Pasig City and Mandaluyong City were only approved in 2010 due to civil society pressure. The mayors of both cities are quite proud of the impacts of the charter to their services provided to their constituents. Some city officials, however, admitted that they do not fully comprehend their Citizen's Charter (Honasan 2012) - a pattern quite common among local officials (Saguin 2012). ${ }^{5}$ The Citizen's Charter, however, only serves as a basis for demanding services that are already operational as it does not include strategic policy decisions on public goods, such as housing, land and environmental resources. Nevertheless, the implementation of Citizen's Charters has led to community groups and private sector demanding better implementation of both policies and programmes.

Governance of Mandaluyong City for the past twenty-six years, has rested mainly on the two political clans of Mayor A and Congressman G (see Figure 2.1). This is affirmed by the voting patterns and list of winners obtained from the Commission on Elections. While incumbent officials in other places (such as India) have not maintained their stronghold in local politics, those in Metro Manila have been able to do so, in part because of their implementation of networked governance practices detailed here.

The mayors of Metro Manila tend to make themselves highly visible before their constituencies through their local programmes. Aside from the payment of taxes and fees, commercial and industrial establishments have to obtain or renew their business licenses and licenses to operate, among others, which need the approval or signatures of the mayor, other officials and/or civil servants. The business license plates - nailed to the wall of every business establishment as evidence of its legitimate operations - in most cities in Metro Manila have a picture of its mayor and the city. And no less than twenty

5 Personal communication with Marivel Sacedoncillo, director of the Local Government Academy affirmed this pattern. 
Case Box 1. The A and G Political Families in an LGU in Metro Manila

A. Sr. (Officer in Charge) ${ }^{*}: 1986-1987$

Mayor A Sr. (1988-1991; 1992-1995; 1995-1998)

Mayor A1 (son): 1998-2001; 2001-2004

Mayor NG (close party mate): 2004-2007 (was Congressman in 20072013) Mayor A1 (son): 2007-2010; 2010-2013

Mayor NG: became mayor in 2013 elections while mayor Aı became congressman

Since 1986, the A and G families have just exchanged their political positions when their allowed terms expire (3 year terms are allowable).

*Appointed by Pres. Corazon Aquino after People Power in 1986;

appointed by Pres. Arroyoto chair of Metro ManilaDevelopment Authority (2001-2002); appointed COMELEC Chair in 2002 until his resignation in 2007 due to allegations of corruption.

FIGURE 2.1 Political genealogy of local chief executives in Metro Manila: The A and $G$ political families in an LGU in Metro Manila.

SOURCE: COMPILED BY THE AUTHOR.

signatures are needed from the city hall and other regulatory agencies for, for example, the conversion of a residential lot to a commercial-industrial one.

And there are yet other ways for the mayor to make himself visible and influential. His picture is almost always appended to every service vehicle of the local government, every programme supported and every activity/event of which he is a major guest or supporter. ${ }^{6} \mathrm{~A}$ good example are the billboards announcing the time to pay taxes. A reminder to business establishments that their support is very crucial for the services provided by the city (police, social services, health, education, et cetera). Alongside this announcement are also the names of all the officials who constitute his 'dedicated service team' for his people. This is one way of 'aligning' other officials to support the mayor's political line of service, which can be viewed by all the citizens.

6 Because politicians and government officials alike have fully mobilized the potential of communication resources (tarpaulin banners, brochures, bulletin boards, texting, LGU website, et cetera) to 'plaster' their faces in public domain spaces, they have witnessed a recent backlash. Even President Aquino has criticized some public officials for using people's taxes to finance their political propaganda. Transparency International, an NGO, has initiated a campaign (Anti-EPAL) against this common practice among public officials, whether elected or not, to append their faces/names to public-funded services and programmes. 
Often, these 'business processes' become spaces for aligning establishments and groups to become partners of the mayor's priority programmes. During key events, organizers from the community and private sector would often request that the mayor or his representative be the guest of honour. This is, in part, to assure themselves to be 'on the good side' of the LCE and his allied officials/staff. These spaces, in turn, also become 'negotiating points' for special favours by businessmen and community leaders who might need 'support from city hall' with their operations.

This kind of clientelistic personalism seems to inform many transactions between the LCE and local leaders and citizen groups as will become apparent when we delve further into the everyday execution of the Urban Renewal Program of Welfareville. As mentioned earlier, Mandaluyong ranks sixth among Metro Manila's wealthiest cities, but it also houses the most congested urban poor settlement in the city - the Welfareville Community.

To improve the area, the local government created the Urban Poor Affairs Office (UPAO) and the Welfareville Commission, which was heavily supported by the city's health and social work and development units. Alongside this, the mayor created the Urban Renewal Programme (URP) in Welfareville to address the problems of poverty, lack of security of tenure and inadequate social services. The programme has mobilized all government, civil society and private sector resources to: (1) ensure security of land tenure for the urban poor families; (2) generate support for social housing from national government sources; (3) enhance the capabilities of NGOS/CBOs in conducting social preparation and continuous cooperation of the people's organizations and of the community; (4) establish mechanisms for сво empowerment towards participatory governance; and (5) work for a more meaningful principled partnering with NGOs, the private sector and other sectors. ${ }^{7}$

To meet the above objectives, the URP partnered with NGOs/POs and business groups in a variety of ways: (1) continuous updating of the listing of informal settler families (ISFs), (2) securing the safety of neighbourhood blocks by ensuring that no outsiders can build housing in the area; (3) mobilizing resources from government and business partners; (4) mobilizing savings amongst the neighbourhood blocks; (5) formulating a comprehensive land and housing development plan for Welfareville. Factors integral to these strategies include community preparation and organization, education and capacity-building (training, seminars and workshops provided by the programme), participation of all stakeholders in the projects, and networking and establishing linkages with other interested sectors. These integral

7 From the programme description. 
components of 'empowerment' are part and parcel of the programme, and include setting in place systems of monitoring and sustaining it. Likewise, control mechanisms, such as against squatting and squatting syndicates, are installed and institutionalized in collaboration with the Cвоs, the NGOs, the police, the private sector and church groups (see figure 2.2 below). This is continually reinforced by the programme's advocacy work and continuing development of its staff, and the mobilization of the beneficiary communities' savings, and is monitored regularly from the Welfareville Commission, the Urban Poor Affairs and the Office of the Mayor. One major victory for these governance networks, after years of demolition threats, saw the mayor bring the DSWD secretary (property custodian of the national government) to a Town Hall meeting before 4,00o Welfareville residents in October 2011, convincing the latter to agree that people shall never be moved under them. After this, they posted several signages (displaying their names and faces) in

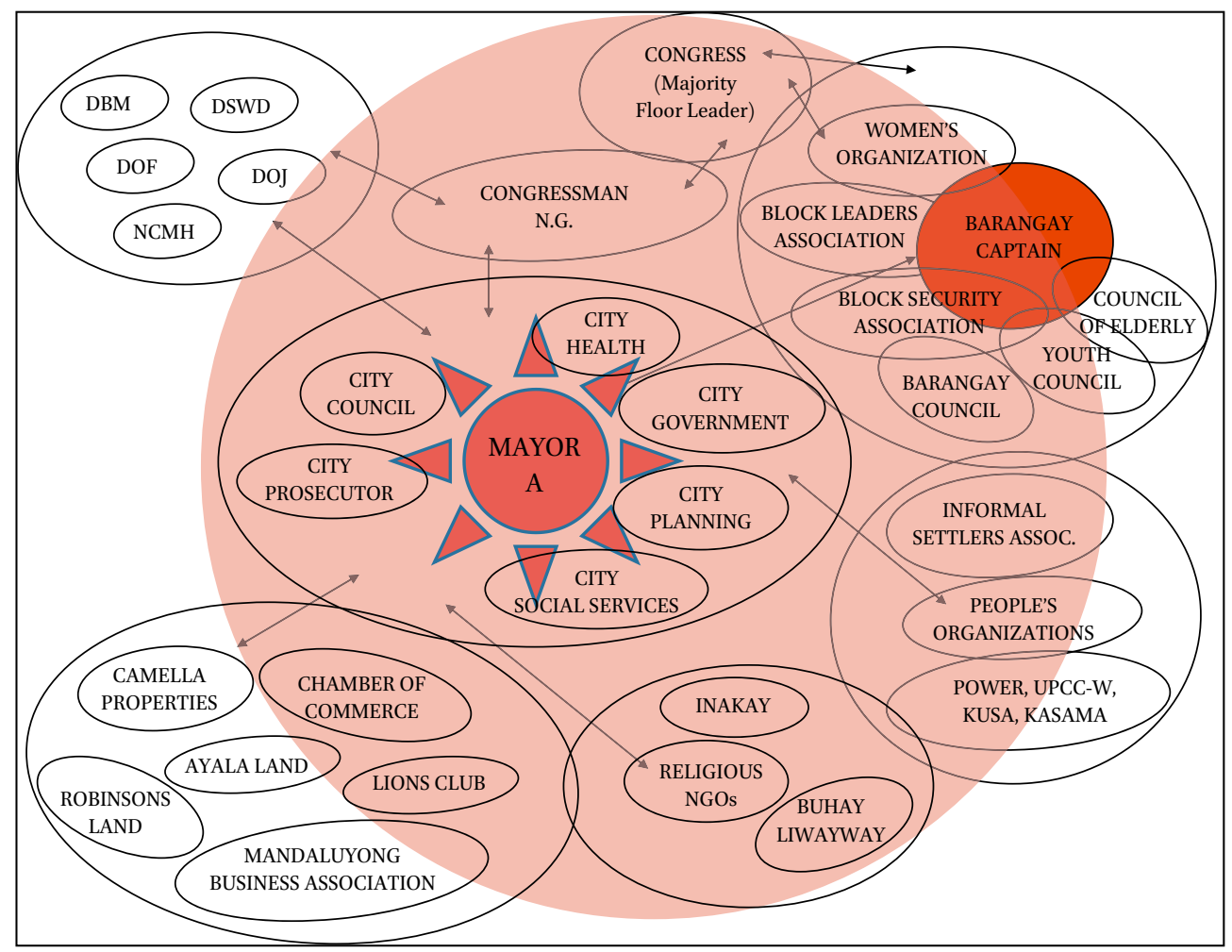

FIGURE 2.2 Networks of partner NGOS/POs, business and government in the Urban Renewal Programme in Mandaluyong City.

SOURCE: COMPILED BY THE AUTHOR. 
public places around the city, assuring their constituents in Welfareville that, while they are serving as leaders, the informal settlers will not face danger of being relocated, nor will their houses be demolished.

The key point here is that these different partnerships are not just strategies to improve governance, but that they also facilitate political mobilization during elections. Thus, the building and control of 'vote banks', like that of Welfareville during elections, is all part of the networked governance strategy that the mayor of Mandaluyong has employed to construct his political clientelism. The people in Welfareville represent a major 'vote bank' of mayor A2, who has belonged to one of the ruling political families for the past twentysix years in Mandaluyong City. In almost all local elections since 1987, both father and son have always captured about $90-95 \%$ of the community's vote. These votes have been maintained over the years because of positive transactions and exchanges between the community and the city hall officials. To fully understand how this is articulated in the urban renewal programme of Welfareville, let us examine below the governance networks of the city mayor in relation to the barangay governance of the community (see figure 2.3 below).

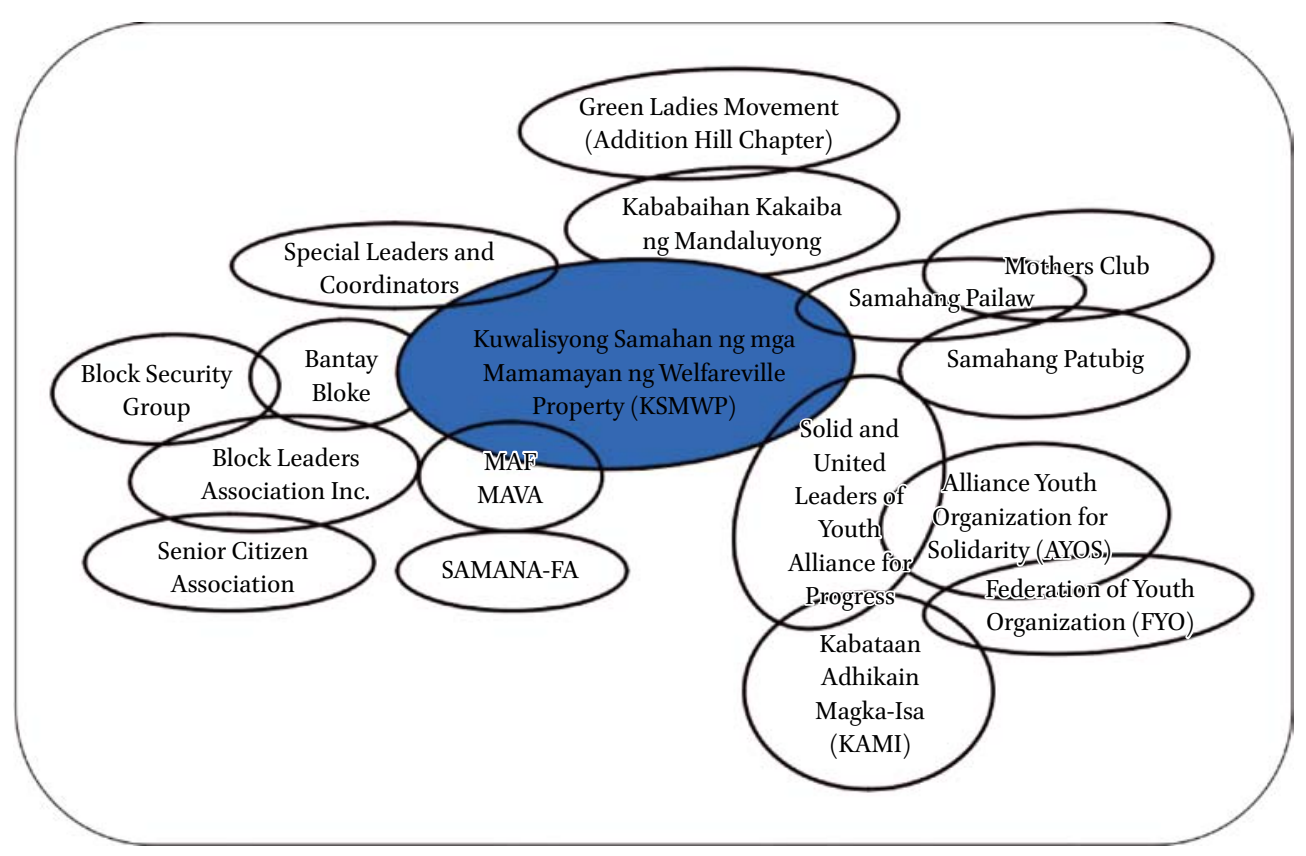

FIGURE 2.3 Allied networks of NGOs and community-based organizations (cBOs) associated with the mayor's Urban Renewal Programme in Welfareville. SOURCE: COMPILED BY THE AUTHOR. 


\section{Privileged Access to Services}

The appropriation of community associations and engagements by mayors, along with citizen groups and csos, has also been selectively instrumentalized by the constituent groups themselves in Welfareville. The residents are quite aware of their 'contribution' to the mayor's continuing hold of power in local governance and their votes during elections. Several community leaders asserted: 'We in Welfareville contribute the biggest chunk of the vote for the mayor. He needs us, so when we ask for something, he does not hesitate to give it to us'. From their point of view, it is a mutually beneficial relationship, with their leader providing 'security' from being evicted by the landowner (national government agency) and rallying behind them to obtain housing security and social services like water, health and basic education. 'Madali naming malapitan ang aming mayor tungkol sa mga pangangailangan namin. Sabi niya hindi niya kami pabayaan na maalis kami dito. Tulungan niya kami sa paglalaban naming para magkaroon kami dito ng sariling tirahan!' (We can easily approach the mayor for our needs. He told us he will never allow us to be evicted from here; he will help us in our struggle to own this land!). These were their assertions during the community mobilizations initiated by Welfareville residents before the City Hall, in protest of the national governments' move to sell the property and relocate residents outside the city. Clearly, citizen groups here treat their local leaders as protectors from external assault by, for example, the national government or realtors/developers.

Furthermore, these partnerships help the mayor construct the impression with his constituency that the provision of public services is due to his help, as local organizations can use their newly acquired political links to solve bureaucratic hurdles. These above partnerships, especially those with marginalized groups, are also accompanied with incentives/rewards, such as easier access to services, government resources and casual employment, and support of the mayor and other local officials. Correspondingly, there are also disincentives (such as non-recognition or non-approval of their participation or of their activities) for those who are not very cooperative (non-alignment with political objectives of the LCE or non-support for its flagship programmes, for instance).

In particular, the functioning of the barangay, the local government unit, can illustrate how access to public services is highly politicized and traded for electoral support. One example regards the way in which people acquire government-recognized ID. To obtain this, one must first apply for a barangay clearance, which firstly needs certification of being a resident and, secondly, requires proof of being a good citizen of the community from the barangay captain. Clearances from the barangay and the National Bureau of 
Investigation are also required for employment applications and any formal transactions with institutions. Barangay clearances released to residents are written on a letterhead and include the names of the mayor, barangay captain and his officials.

Barangay leaders mobilize their connections with the mayor to negotiate the implementation of urban renewal programmes to determine, for example, housing designs and beneficiary upgrades. These urban renewal negotiations in the community are very much interwoven with the provision of social services and security. Discussions and decisions about these issues are often taken up during weekly/bi-monthly meetings of the community-based organizations (e.g. block security brigade, block leaders brigade, youth/women's/ senior's council, et cetera) which are held alongside other community sociocultural events (such as monthly sports-fest, health or community fair) and political events (e.g. executive, legislative and judicial sessions of the barangay council) that provide a good excuse to invite the mayor or his representative to honour their event or programme.

A second example of the clientelistic exchange of services for support regards the organization of social and security services (water, health, police, et cetera). This is prepared through several community organizations such as the bantay bloke or neighbourhood watch group, water block group, women's/ youth group, mothers club, senior citizens group, anti-drug campaigns by youth groups and senior citizens, et cetera). These groups regularly receive 'gifts' of resources from the mayors' and barangay captain's social services fund (for example, ham for all senior citizens during Christmas, birthday cakes for all those born in Welfareville, gift packs and assistance for all the block leaders and sectoral leaders, et cetera. About these gifts, the barangay captain will say, 'This is how our leader really cares for us!' But these organizations are actually mobilized by community leaders and residents alike to ask for services and assistance, especially during emergencies, from the mayor and city hall officials. In exchange, these organizations form the backbone of election campaigns as they help to spread the word about the mayor's support for ordinary people like them. One resident told the author: 'I was so touched that our mayor helped me with the hospital expenses of my mother; considering how busy he was, it touched me even more that he took the time to help me'. Supporters provide such testimonies during campaign sorties and political meetings in the barangay hall or town plaza. They help organize house-to-house campaigns of the mayor and his party. More importantly, while performing their community duties, they serve as the mayor's 'eyes and ears' and report on developments that may affect the mayor's political fortunes in their locality. 
These exchange relations illustrate how good governance indicators (accountability, transparency, efficiency/effectiveness, community participation and empowerment, innovation, sustainability) have been taken up by local chief executives to enable the strengthening and elaboration of clientelistic networks through which they can mobilize particularly marginal communities. As the case study from Pasig will also illustrate, city mayors have strategically appropriated or instrumentalized the strategies and discourses of good governance - engagement of civil society actors in governance routines and collaboration with private sector - to fulfil their need of building up networks that can facilitate a clientelistic exchange of access to state resources for political support.

\section{A Second Case Study: Pasig City's Greening Programme}

Pasig City, one of the oldest cities of the Philippines, ranks fourth in terms of economic GDP and demographic growth in Metro Manila. Located approximately twelve kilometres east of Manila, its area is sprawled along the banks of the Marikina and Pasig rivers, with the Napindan Channel draining towards Laguna Lake. Given its environmental location, flooding in the city has caused much damage to property, as well as death/injuries among the residents, thereby greatly hampering the city's economic growth. The flagship programme of the mayor, the Pasig Green City Programme, is crucial for the city's development.

The city, as shown in figure 2.4 below, has been politically controlled by one family in particular since the early 1990s.

For most local chief executives, their vision for the city will factor in that of the mayor, including existing governance strategies. When mayor RE Jr. unveiled the Pasig Green City Programme before a large assembly and the

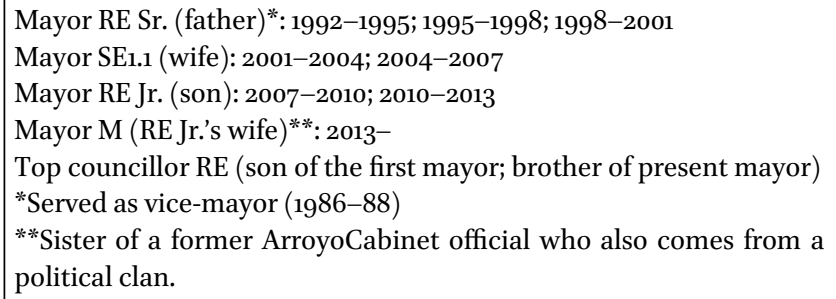


media, he envisioned the city to be 'a progressive city with clean air, a safe and healthy environment, where there are lush urban forests and green spaces', moving 'towards a more ecologically sound community of empowered Pasiquenos through a constituent-responsive leadership'. He, then, challenged the citizen's assembly before him 'to join, participate and support me in creating a paradigm shift in governing the city'. He called upon the citizens to adopt the motto, 'Beyond progress; A healthy environment', and used multisectoral and multidisciplinary approaches to implement it. In this comprehensive programme, climate change (e.g. GHG Inventory, management and accounting) and all other environmental programmes were integrated to the social, economic and development programming of the city. The mayor gave his 'visioning speech' in 2009, after Typhoon Ketsana submerged $70 \%$ of the city for several days/weeks, giving him an excellent rationale for his flagship programme, along with the City Environment and Natural Resources Office (cenro). He then deputized the cenro and the Pasig Command, Communications and Control Centre (Pasig $\mathrm{C}_{3}$ ) to be the key arm in implementing his environmental programmes. The latter office has been purposely organized by the mayor as the nerve centre for directing and coordinating traffic, emergency and disaster situations and the focal point for counter-emergency and/ or disaster plans.

Pasig $\mathrm{C}_{3}$ brings together all aspects of communication, information, warning and alerting of residents, situation assessment and monitoring and overall coordination of initiatives towards an environmentally-safe and -sound city. It also serves as a communication link to other service units provided by the city government, such as social services, public safety and order, traffic management, environmental services and public information with a 24/7 emergency monitoring operation. It has various system components in order to perform its functions: (1) computer telephony interface; (2) computer-aided dispatch with GIS capability; (3) centralized communication console Motorola command lite; (4) geo-mapping system; (5) GPS vehicle monitoring readiness; (6) research and manpower database; and (7) road management monitoring. Pasig $\mathrm{C}_{3}$ collaborates with CENRO and the Pasig Search and Rescue Unit, which has the following programme components: (1) earth and landslide search and rescue course to all communities; (2) barangay cluster emergency teams; (3) rescue training programmes with public/private schools and business establishments; and (4) a safety inspection and building emergency evacuation plan for Pasig for every building and establishment within the city.

Central to the mayor's community organization and mobilization approach is the engagement of community volunteerism. Thus, all the mayors' environment programmes, implemented through the City Environment and Natural Resources office (CENRO), employed the following governance strategies: 
1. The community-based volunteer groups like the Green Police and the Tanod Sapa (Creek Security). There are currently approximately six hundred volunteers from thirty barangays or communities.

2. They organized the Environmental Brigade, and the Bantay Ilog (river watch) from the thirty barangays of the city.

3. They enacted environmental ordinances and strict enforcement of laws, requiring all establishments to secure an Environmental Permit to Operate prior to the issuance of a Business Permit and to install anti-pollution devices.

4. They have effected a recycling and livelihood programme in partnership with schools and parents' associations and private establishments.

5. They implemented massive greening and anti-pollution programmes in partnership with своs, NGOS and the private sector.

This community volunteerism served to address the city's high unemployment, or underemployment rate, among the informal settlers living along the river banks and creeks. Volunteers, called Green Police and River/Creek security, receive meal and clothing allowances (or a cash equivalent of 2,500 Philippine peso, about 60 us dollar per month). As such, they have been deputized to apprehend violators of environmental laws and ordinances of the city government. When queried, the volunteers explained: 'Sinusuwelduhan kami at nagkaroon ng karapatan sa bayan name na magpuna sa kapwa' (We have now salaries and have the right to reprimand our neighbours when they are not observing environmental ordinances!'). These functions have allowed them to become powerful 'eyes and hands of the mayor.' In practicality, these community volunteer brigades have become a sort of semi-casual employee of the city hall through the courtesy of the executive office. Their 'appointment' as volunteers is co-terminus with the mayor's term, but these volunteer groups have also organized themselves into people's organizations in their respective communities with support from environmental NGOs, civic groups and national agencies like the Department of Natural Resources or the Pasig River Rehabilitation Commission, et cetera. These same volunteer groups, alongside NGO and private sector partners, are also mobilized during regular community assemblies, multisectoral consultations and forums organized by the LGU. Thus, the mayor's programmes have successfully engaged the cooperation of networks of actors from NGOS/CвOS/POs, business-related associations, and professional organizations. They have also forged partnerships/linkages with

8 Personal interview with Raquel Austria-Naciongayo, CEnRo officer of Pasig City. 
agencies from national government and quasi-government organizations to make their environmental governance more efficient and effective. But these 'volunteer' spaces have also become 'transactional or negotiating points' for the citizen groups active in these areas to ask for budget allocations for their community activities or for access to resources for their families (for example livelihood and health services). 'Kasi tumutulong kami sa kanya, Itong grupo naming tinutulungun din ng mahal na mayor naming kung may hinihiling kami sa kanyang tulong, halimbawa additional budget para sa aming daycare center, o, tulungan makapasok ang anak ko sa trabaho at iba pa' (Because we help him, our beloved mayor always helps us when we ask for help, say additional budgets for our day care centre, or my son's reference for his factory work, et cetera). In short, the collaborative partnerships crafted here become arenas for exchange of resources.

The linkages of the governance actors and networks active in the local governance of Pasig City can be seen in the graphs below (figures 2.5 and 2.6):

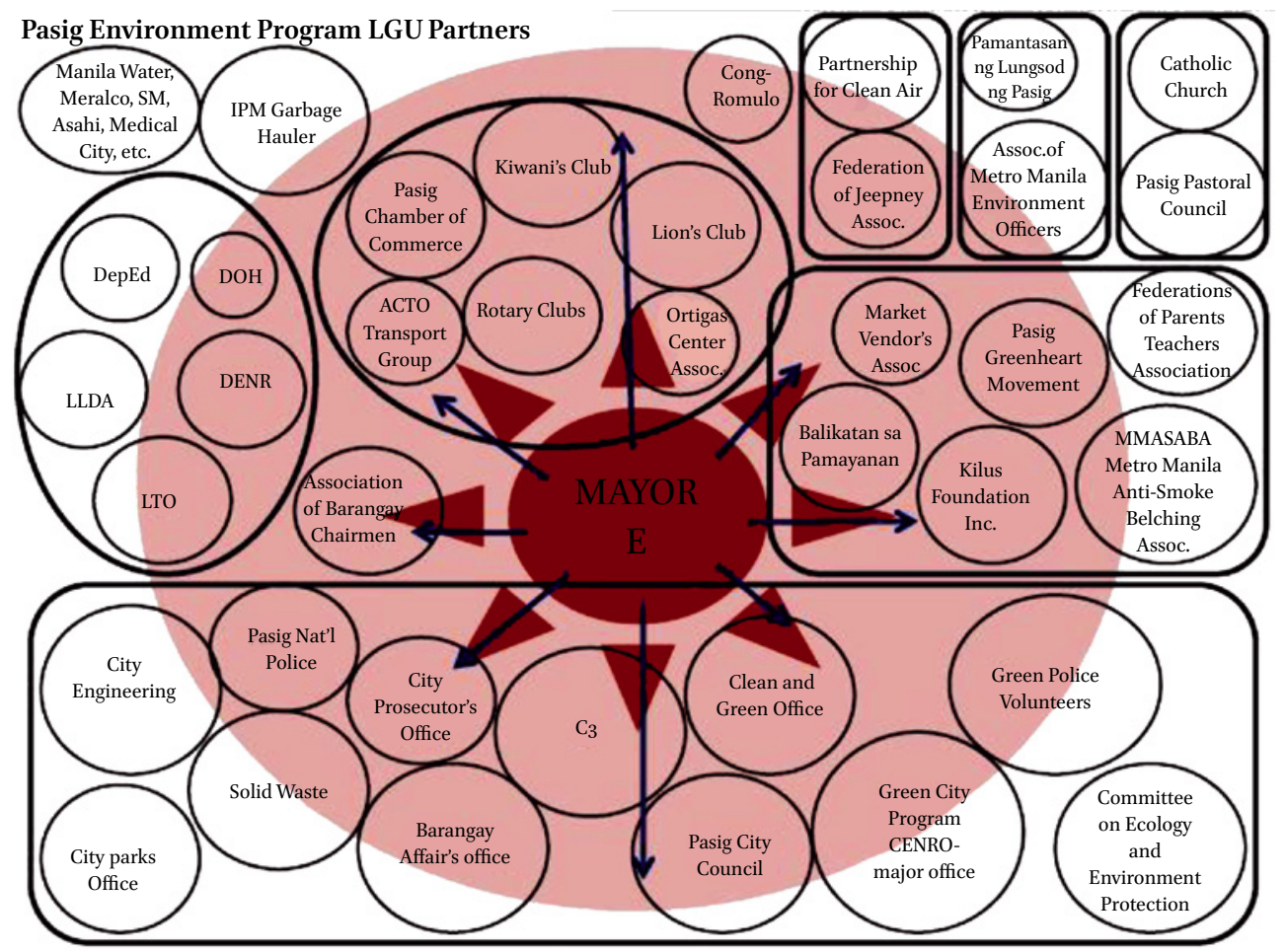

FIGURE 2.5 Pasig Green City Programme and its social map of power sites. SOURCE: COMPILED BY THE AUTHOR. 


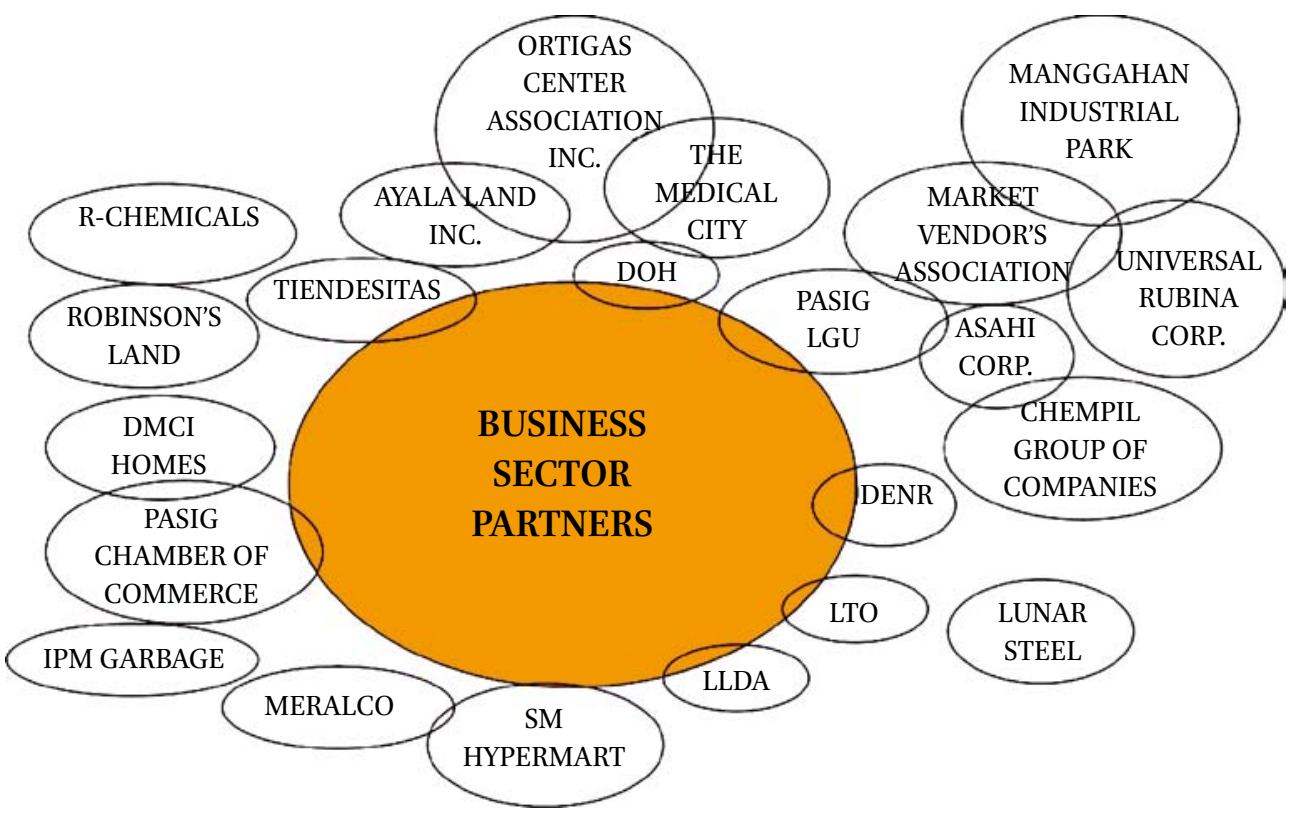

FIGURE 2.6 Networks of business partners in Pasig City's environmental governance. SOURCE: COMPILED BY THE AUTHOR.

Increased resource access by local chief executives under a decentralized regime has empowered them to engage organizational networks in formulating and implementing his priority programmes. Thus, the creation of networked governance structures by LCES have contributed greatly to the persistence of the same power holders in this city. These graphs show the intersections of actor networks mobilized by the mayor and his offices to achieve the goals of local autonomy and development. By doing so, they also perpetuate the control and power of their families in local politics.

\section{Summary and Conclusions}

How is it that, despite the democratization of local governance in the Philippines, predatory politics and clientelism still persist? This article has argued that one answer to this question lies in the way in which government interaction with civil society enables political elites to strengthen their dominance. Studies of decentralization and democratization in the Philippines have often highlighted how local governments and officials construct collaborative engagements with civil society (NGOs/POs/CBOs) and the private sector in policy-making and implementation of their key programmes. In large part 
these strategies have engaged citizen groups to participate in the governance of their cities and localities, but these citizenship engagements and practices have been recasted by political dynastic families to strengthen and further entrench their control and power over local governance. As seen in the above case studies, the relationships and patterns of engagement between both government and non-government actors have indeed become more decentralized, transparent, consultative and participatory. However, local political elites instrumentalize these interactions to create horizontal and vertical networks with NGOs and своs (especially from the marginal sectors) and the private sector in a way that generates a dependent and clientelistic relation. In this sense, LCEs have successfully re-constituted old formations (such as Своs) to make them align and support their programmes, whilst also providing support during elections. Their success in mobilizing these groups can be largely contributed to their continuing dominance in local politics. The employment of networked governance strategies by local chief executives from dominant political and economic elite families allows them to govern their constituents in a seemingly very participatory, transparent, accountable and effective manner, yet they continue to maintain a political stronghold over them.

These governance strategies do not seem to be perceived as predatory, clientelistic and appropriative by these partners because their own interests and goals are also achieved by these collaborative relationships. In the context of a state that is difficult to access, these governance networks serve citizens to obtain privileged access to certain state resources. Citizen groups outside of these networks often complain about the tendencies of these arrangements to exclude others, who are critical of the government, from being able to partake in the distribution of programme-related resources.

Traditional power elites, such as the mayor and the dominant political families of Mandaluyong City/Pasig City in Metro Manila, are able to use democratization and decentralization to their own advantage by employing what I termed 'networked governance strategies'. These strategies consist of the following four elements:

1. Community participation and empowerment effected through consultation, dialogue, and community assemblies with marginalized groups (e.g. the urban poor, street children, homeless people, et cetera) and the creation of opportunities for citizens to 'volunteer' as guardians of the environment (such as the green police) or of public safety (like the Block/ Neighbourhood Watch).

2. Crafting tripartite partnerships with NGOs/CвOs/POs and the private sector in policy formulation and/or project/programme implementation through participatory planning processes, starting from the community 
and linked to other communities through the municipal-wide consultation and planning assemblies. These partnerships gain the capacity to engage in the formulation of local regulatory frameworks, policy-making and implementation of their programmes.

3. Enabling members of these partnerships to gain privileged access to state resources (as citizens) or permits and licenses (for private sector partners).

4. In exchange, civil society leaders use their local prominence to support the election campaign of the mayor and mobilize people to attend rallies and ceremonies during these campaigns.

Decentralized and democratic governance practices like consultation, public hearings, participation and consensus-building are used to generate horizontal and vertical networks of allied NGOS/C BOs and private sector groups. While these groups are rewarded by increased access to state resources, they nevertheless become embedded into a subservient patron - client relationship.

Yet, the networked governance strategies of local governments in the Philippines have really transformed the hierarchical and bureaucratic relationships of local officials with citizen groups and other non-government actors. As seen in the cases above, the LGU officials' networking, negotiation, bargaining systems and coalitions have incorporated non-government actors into the formulation of local regulatory frameworks, policy-making and the implementation of their flagship programmes. Thus, these collaborative arrangements and negotiations have increased the capacity of some civil society groups to shape the implementation of government programmes. The emerging shifts, then, in the locus of power within and across local governance structures, demand that we pay attention to the social production of power of these interactions and networks, dominated by political families in alliance with groups in civil society and the private sector. These practices seem to remind us of the earlier forms of political clientelism, while the discourse of participation and democratization has made the continuation of clientelistic practices appear more legitimate. While these create potential spaces for repositioning or recalibrating the locus of power, they could actually become the engine for reproducing and further mobilizing power in networks already dominated by political families, which have become 'democratized' because of their collaborative partnerships with key leaders from civil society and the private sector. In this sense, the twin forces of decentralization and democratization have simply made it more possible for the local chief executive to systematize the construction of power sites with politically aligned networks of support and reinforce his dominance in local politics. 


\section{References}

Ballesteros, M.M. (2010). Linking poverty and the environment: evidence from the slums in Philippine cities (Discussion Paper Series No. 2010-33). Makati City: Philippine Institute for Development Studies.

Guevara, M. (2004). The Fiscal Decentralization Process in the Philippines: Lessons From Experience. Hitobashi Journal of Economics, 41(2), 97-109.

Holmes, R. (March, 2011). The curious cases of civil society and decentralization. Paper presented at the Philippine Social Science Forum on Decentralization and Governance, Philippine Social Science Center, Quezon City.

Honasan, S. (2012). Failon Ngayon: Citizen's Charter. Retrieved January 26, 2016, from http://news.abs-cbn.com/current-affairs-programs/og/10/12/failon-ngayon -citizens-charter.

Karaos. A.M (1997). Urban Governance and Poverty Alleviation in the Philippines. In E.Porio (ed.), Urban Governance and Poverty Alleviation in Southeast Asia: Trends and Prospects. Quezon City, Metro Manila: Center for Social Policy and Public Affairs, Ateneo de Manila University.

Langran, I.V. (2011). Decentralization, democratization, and health: the Philippine experiment. Journal of Asian and African Studies, 46(4), 361-374. doi: 10.1177/0021909611399730.

Leviste, E.N.P. (2004). Bounded pluralism: politics and participation in health policymaking. Philippine Sociological Review, 52(1-4), 37-54.

National Statistical Coordination Board (NSCB) (2010) Interactive Statistics. http:// www.nscb.gov.ph/activestats/psgc/municipality.asp? muncode $=137601000 \&$ regcod $\mathrm{e}=13$ \&provcode $=76$. Accessed September 8, 2012.

Porio, E. (2002). Urban Poor Communities in State-Civil Society Dynamics: Constraints and Possibilities for Security of Tenure in Metro Manila. Asian Social Science Journal, 3o(1), 73-96.

Porio, E. (2009). Shifting spaces of power in Metro Manila. City: analysis of urban trends, culture, theory, policy, action, 13(1), 110-119.

Porio, E. (2012). Decentralization, Power and Networked Governance Practices in Metro Manila, Space and Polity, 16(1), 7-27.

Porio, E. (2014). Climate Change Vulnerability and Adaptation in Metro Manila: Challenging Governance and Human Security Needs of Urban Poor Communities. Asian Journal of Social Science, 42(1-2), 75-102.

Rivera, T. (2011). Philippine elections and political parties and democratic accountability, 1986-2010. Paper presented at the Philippine Social Science Forum on Decentralization and Governance, Philippine Social Science Center, Quezon City.

Rocamora, J. (2003). The Constituent Assembly Is Dead: Elect Concon Delegates in 2004, Philippine Daily Inquirer, January 25. 
Rood, S. (1998). Decentralization, democracy, and development. In D.G. Timberman

(Ed.), The Philippines: New Directions in Domestic Policy and Foreign Relations. New York: Asia Society.

Saguin, K. (2012). Implementing the Citizen's Charter Initiative in the Philippines: Insights from Selected LGUs. Paper presented in the National Conference of the Philippine Society for Public Administration, Development Academy of the Philippnes.

Virola, R. (2010). Statistically Speaking. http://www.nscb.gov.ph/headlines/StatsSpeak/default.asp. 


\title{
Everyday Citizenship in Village Java
}

\author{
Takeshi Ito
}

Citizenship has gained currency as a key concept in the global strategy to promote and deepen democracy. For a strong and well-functioning democracy, the argument goes, ordinary people should be willing and able to participate in the decision making process that affects their lives as rights-bearing citizens. For donors and international aid agencies leading this democracy drive, 'traditional' and 'vertical' social relations - including patron - client relations - are deemed to be incompatible with democracy. Subjects need to be transformed into rights-bearing citizens. Citizenship, understood in this manner, is often uncritically linked to specific configurations of institutions and framed within the rhetoric of liberal democracy, with political and civil rights that realize citizen participation and deliberation. Perhaps, because of this normative bias, there is a relative dearth of research on the actual experience and practice of citizenship. A bulk of the literature on citizenship focuses on the normative attributes of citizenship such as the legal status and rights of citizens, but less on the form and nature that citizenship actually takes in postcolonial countries (Robins et al., 2008; Cornwall et al., 2011; see this volume's Introduction).

Citizenship can be understood as a relational process, shaped by everyday interactions between state and citizen (Chatterjee 2004; Holston 2008; Lund 2011). While the actual forms of citizenship in developing countries like Indonesia remain far from the normative ideal of liberal democracy, we cannot simply dismiss such 'deviations' as 'democratic deficits.' Instead, citizenship needs to be studied not only in terms of citizenship rights and duties, but also in terms of how these rights and duties actually shape and are shaped by everyday state - citizen interactions. In practice, citizenship rights and status are often weakly enforced, to the particular detriment of weaker groups such as women, minority communities, and the poor. Despite the emphasis on the institutional domain of citizenship, the weaker groups are tenuously linked to the state through it. In other words, as this article argues, the everyday forms of village citizenship is not so much bound by the institutional domain of citizenship but rather by personal relations with immediate power holders in their community.

In Indonesia, since the Reformasi era (1998 - present), new democratic institutions such as the direct elections of the president, regional and village 
heads, village council and participatory development planning were established as part of the democracy drive to fix the broken linkage between elected officials and citizens. ${ }^{1}$ At the same time, these new democratic institutions were accompanied by a host of new democratic concepts - emany of them are English-loaned words - asuch as demokrasi (democracy), desentralisasi (decentralization), otonomi daerah (regional autonomy), partisipasi (participation), transparansi (transparency), and akuntabilitas (accountability). Despite the foreign origins and technical nature, however, these words have been used, often without local translations or further explanations, in local government regulations, guidelines and political campaigns at the local level. With the introduction of the democratic institutions and language, villagers are expected to act like citizens by using their rights to participate in the decision-making process and to deliberate policies and issues that affect people's lives.

However, the new institutions and language are not automatically translated into the democratic practice of citizenship rights and duties framed by the language of liberal democracy. At the village level, these new institutions and language are also being adapted to the day-to-day process of local politics. Crucially, in this process, they do not replace old actors and institutions, but rather are integrated into the existing institutions of power (Bierschenk and Olivier de Sardan 2003). In other words, the integration of new institutions into the existing institutions of power creates layers of power where new institutions of power sediment on the old layers of power. Thus, the everyday form of citizenship is mediated at the village level where the institutional domain and logic of citizenship integrate with the local logics and processes of power relations. For instance, while the rural poor in village Java are expected to realize their citizenship by incorporating these new democratic institutions in their day-to-day activities, they might find little usefulness or benefit in doing so because the rural poor's ability to make use of the new institutional framework is mediated and shaped by the layers of power.

This article explores state - citizen interactions in democratizing Indonesia with a focus on the role of village officials in linking villagers to the state and its impact on the extent of citizenship for the rural poor. The focus on the role of village officials in democratization is important because they are the

1 The democratization process has been full of twists and turns. A major setback occurred in September 2014 when the House of Representatives (DPR) passed Law No. 23/2014 on Regional Government that annulled the direct elections of governors, regents, and mayors. A few days later, then President Yudhoyono issued two government regulations in lieu of law (Perppu) to save the direct elections of regional heads. In January 2015, the House approved the two government regulations, and reinstated the direct elections of regional heads. 
most immediate formal and informal institutions that directly shape the local forms and experiences of citizenship. To what extent does the institutionalization of citizenship as rights and legal status transform the existing forms of patronage politics and clientelistic relations in society? How is citizenship perceived, experienced, and practiced by elites as well as by the rural poor? How do different degrees of their understanding of citizenship give shape to the everyday practice of citizenship?

The everyday form of citizenship is tightly linked to political strategies of the poor. While the establishment of rights, legal status and citizenship regime depend primarily on state capacity, the everyday form of citizenship is contested and remade by interactions between various actors with varying degrees of access to power and resources through formal and informal institutions such as rights, voices, and clientelism. As will be examined, the everyday form of citizenship that the rural poor experience is not shaped by how well citizenship rights are defined, but by how the rural poor engage in politics to get by every day, including clientelistic relations with immediate power holders in their community. This article narrates and situates stories of everyday citizenship experienced by the rural poor in a Javanese village, and explores the complex relation between clientelism, citizenship and democracy by working back from these stories (Robins et al., 2008:1082). These stories suggest that the rural poor perceive, experience, and practice citizenship in a manner quite different from the ideal-type of an autonomous, engaged, rights-claiming citizen. By taking this disjuncture as a lead, this article traces the origins of layered citizenship in the tenuous linkage between state and citizen deeply embedded in a particular trajectory of state formation in Java.

To understand why the rural poor are tenuously linked to the state, the next section examines a particular trajectory of state formation that left intact formal and informal power structures side by side. In doing so, it attempts to shed light on the close relationship between state formation and postcolonial citizenship in the historical context of Java and to provide an analytical tool to make sense of what is going on in terms of the rural poor's relationship with village elites.

\section{State, Property and Citizenship}

Indonesia's citizenship regime is highly layered and differentiated. While the law stipulates that every Indonesian citizen has the same rights, citizenship is particularistic, shaped by power relations rooted in social category, identity, class and property. This means that citizenship is a relational process, shaped 
by everyday interactions between state and citizen. The character of these interactions is shaped by trajectories of state formation (Introduction to this volume; Mamdani 1996; Tilly 2004; Schulte Nordholt 2005; Van Klinken 2009; Cornwall et al., 2011). State formation in this context is not only a top-down process of extension of state domination, legalization of privileges and entitlements, and invention of social categories and traditions. State formation is also a bottom-up process of increasing citizen/subject participation in state affairs. This increased involvement evolves through local elites who broker interactions with state institutions, functioning as a lubricator between state and society (Hirsch 1989; Agrawal 2001; Ito 2011). Crucially, in this process, informal structures of power are not necessary absorbed and eliminated, but rather coexist next to formal state institutions. The manner in which state agents establish the legitimacy of state power and impose consent on local people through local elites gives rise to particularistic exchanges of benefits through personal relations marked by patronage and clientelistic practices. As a result, the rural poor in Java were always tenuously linked to the state. They have been incorporated into the state's domain through village elites as a source of labour and the target of rural development. In this process, the village office acting as the interface between state and village has played an important role as a basis of patronage for village elites, and in return they recognized the state's legitimacy of extracting a surplus from the peasants.

How and why did bureaucratic office become an important source of power and material benefits in Indonesia? In his landmark work Indonesia: The Rise of Capital, Richard Robison explored the origins of the weak indigenous capitalist class in Java. Among the three major factors he analysed, two are particularly useful for us: (1) the relative weak institutionalization of private property in pre-colonial society and (2) the persistence, under colonial rule, of political appropriation as the basis for accumulation (Robison 1986:11). The relatively weak institutionalization of private property has roots in the nature of power in pre-colonial Javanese kingdoms. Pre-modern states in Java were far more interested in concentrating their subjects at the core within relatively easy reach, rather than occupying land. 'Mataram Kingdom', writes Ong Hok Ham (1975:45), 'was largely an agrarian state with very little money economy. As a result, relations between king and bupati (regent) were in terms of patron client relationships. In the same way, the bupati's control within the region was based on martial alliances and personal ties with lower priyayi and important villagers'. In other words, the core of a kingdom's rule revolved around control over people through king's charisma, personalized rule and reciprocity based on patron - client relations.

Kingdoms' emphasis on labour rather than land continued under Dutch indirect rule. In colonial Java, state power extended to peripheries by 
formalizing the superior ability of the priyayi (members of the local nobility) to control local people as holders of bureaucratic office. In this process, establishing the village as the lowest administrative unit constituted the essential part of state formation (Breman 1980). 'From 1830 onwards,' writes Robison (1986:14), 'the priyayi were progressively integrated into the machinery of the colonial state and divested of their traditional rights of tribute from the peasantry'. For these intermediaries, land ownership was of little importance for the basis of their economic and political power. Rather, it was access to state power and material benefits associated with bureaucratic office that provided an important source of local economic and political power. Thus, when the colonial state offered the land grants of 1830 , the priyayi turned down the opportunity to legalize their access to land. Instead they chose to maintain power by becoming salaried agents in the colonial state. ${ }^{2}$ Given the weak institutionalization of private property, the priyayi preferred instead to nurture their relation with the colonial state as it provided a more secure source of income.

In sum, this trajectory of state formation through intermediary powers left intact formal and informal power structures side by side. Due to the weak institutionalization of private property, bureaucratic office rather than land provided the basis of patronage for the local nobility and village elites. ${ }^{3}$ For a large part, people's encounter with the state was through intermediaries including village officials whose duty was to collect dues and later to provide a host of other services including social welfare to villagers in the form of rural development. Village office was inheritable at that time, which made village officials immune to pressures from ordinary villagers. From their end, ordinary villagers depended on village elites to interact with the state and its myriad laws, rendering their relationships paternalistic.

This mediated model of the state - citizen relationship was solidified under Suharto's New Order regime (1966-1998). The developmentalist bureaucratic state rendered society disengaged from politics, and mobilized national resources to accelerate economic development. With the windfalls of oil revenue in the 1970s, the Indonesian state developed vast clientelistic networks that distributed benefits and largesse to rural intermediaries in return for political support (Hart 1989; Antlov 1995; Schiller 1996). At the top of this large

2 Robison (1986:11-2) ably put it, 'One of the most crucial developments in the colonial period was the failure of the Javanese priyayi to transform their traditional rights of appropriation over land, labour and produce into rights of private ownership on a large scale.'

3 Conventionally in Southeast Asia the patron depended more on the local organization of force than hereditary status or land ownership. In the nineteenth century, the penetration of colonial government and commercialization of the economy transformed the traditional basis of patron - client relations to land ownership (Scott 1972:101). 
clientelistic pyramid stood President Suharto, from where people, money, and goods moved downwards to support village elites (Antlov 1995). While the clientelistic networks and practices helped the state distribute material benefits, they also came to constitute the primary logic of state - village interactions.

Furthermore, the Indonesian state reduced various forms of village government structures that had remained illegible into the standardized unit of political control. Law No. 5/1979 on Village Government was issued with the stated objectives of 'standardization, demobilization, mono-loyalty, and depoliticization.' The rigid structure of village government helped the Indonesian state realize the virtuous circle of social demobilization, political stability, and economic development. Under the tutelage of the Indonesian state, the village head enjoyed numerous material benefits associated with the position as long as he managed to return the favour by supporting the central government in implementing national development projects and mobilizing villagers to vote for the government party Golkar during elections. In other words, the village head as the enforcer of the central government represented the interest of higher authorities rather than that of villagers. Thus, it was through the vast clientelistic networks and the standardization of village government structures that the Indonesian state was able to extend its reach and to strengthen its control over villages.

With the fall of Suharto's authoritarian regime in May 1998, the clientelistic networks and practices that had characterized the state - village relationship during the New Order era was brought under the critical eyes of experts. The Reformasi era (1998-present) saw the proliferation of foreign aid for democratic institutional reform. ${ }^{4}$ Particularly, the village government structure has been at the centre of the democratic institutional reform. To make a break, the past policies, laws No. 22/1999 and No. 32/2004 on regional government were enacted with the new key words 'diversity, participation, autonomy, democratic, and empowerment' with the aim of democratizing village government. The next section details the experiences of citizenship by the rural poor, relying on

4 Particularly notable here is the significant level of support from donors, international organizations and international charitable foundations to deepen and consolidate democracy. Between 2000-2005, for example, there are 217 governance reform projects in Indonesia, involving twenty-two foreign donor agencies (such as the World Bank, the United Nations Development Programme, the Asian Development Bank, the Netherlands, Denmark, Australia, et cetera) and fifty-eight foreign implementing agencies (e.g. the Asia Foundation, Oxfam-GB, et cetera) (Edi and Setianingtias 2007). These governance reforms focus on several primary areas of governance such as 'civil service reform' (18\%), 'anti-corruption' (17.5\%), 'decentralization' (11.5\%), 'law and legal reform' (9.5\%) and 'civil society empowerment' $(7 \cdot 5 \%)$. Figures in parentheses indicate the percentage of the total number of projects. 
my fieldwork in Bandung District, West Java, conducted between 2004-2005 which was followed up by subsequent multiple visits.

\section{Citizenship in the Rural Periphery of the Priangan Highlands}

Situated on a hillside of the Priangan highlands of West Java, a half-an-hour ride on a country road connecting the village to the central market and a cluster of textile factories in Majalaya, is a rural village that I call Namiwari. ${ }^{5}$ In 2008, 8,785 people lived in the village. Agriculture is a main source of livelihoods for the majority of villagers. On the north part of the village is mostly agricultural land. A stream flowing into the Citarum River provides an important source of water for most paddy fields. Landowning farmers, sharecroppers and agricultural labourers cultivate land for rice, cabbage, peppers, eggplants and carrots. In irrigated rice paddy fields, farmers rotate the cultivation of land with freshwater fish. Sharecropping is still practiced; the local sharecropping system called maro divides harvest in half between landowners and sharecroppers.

Rural villages in the Priangan highlands have been polarized by landownership. Unlike Central Java where communal land possession of paddy fields inhibited the process of land concentration, the Priangan highlands saw the development of heritable individual possession (Kano 1977:15), making the problem of land concentration and landlessness particularly acute. According to an early study of land ownership in Java, by the early twentieth century, one-third of the agrarian population was landless while $9 \%$ of owners $(5 \%$ of the total population) owned over 2 bahu (1.4 hectare) of farmland (Husken and White 1989:40). In order to ameliorate the impacts of landlessness, the Dutch colonial government promoted non-farm employment by creating a major textile production centre in Majalaya.

The problem of landlessness, however, continued to plague the livelihoods of the majority of farmers in Namiwari. Between 1948 and 1962, the Priangan highlands were affected by the Islamic State (Darul Islam) movement. To protect themselves from raids, villagers in Namiwari moved to central Majalaya and elsewhere. As people who had evacuated for safety began to return to the village in the 196os, population pressures on land were increasingly felt. In 1967, population density in Majalaya sub-district as a whole was 1,888 square kilometre and landless peasants accounted for $46.7 \%$ of the total households (Matsuo 1970:62-63). The trend of increasing landlessness in the village continued throughout the 1980 s and 1990s. By 2003, the number of landowning

5 I use a pseudonym to protect the anonymity of the villagers. 
households in Namiwari was 396 or one-fifth $(20.3 \%)$ of the village population. As a result the average cultivated area per household in Namiwari declined from 0.66 hectare in 1967 to 0.55 hectare in 1980 to 0.41 hectare in 2003 . To sustain a family, villagers modestly say, at least one hectare of farmland is required. The average farmland of 0.4 hectare means that the average farmer cannot sustain a family through farming alone. To supplement incomes, many villagers work at textile factories near central Majalaya. Villagers also attend family-run kiosks for snacks and street vendors.

Against this background, development has long been conceived of gifts rather than of rights by both village elites and ordinary villagers. During the New Order era, the government planned and implemented intensive rural development projects to build key infrastructures such as roads, irrigations, schools and health posts and to distribute agricultural credits for seeds, fertilizers and pesticides in the countryside. Because of the clientelistic ties with the state, village elites gained disproportionately large benefits from the implementation and management of these rural development projects. ${ }^{6}$ Village elites invested these gains in agribusiness, transportation business and their children's education to maintain their privileged status within the village.

This is also evident in Namiwari where two influential families have dominated the village office (desa), alternatively taking the position of the village head. ${ }^{7}$ They have managed to control the flows of material benefits from the national and local governments, and distributed them to villagers in a clientelistic manner. Cece, the first village head (in office 1983-1994) and a son of the village police, began his career like his father as the village policeman in 1968. When Namiwari separated from Wonosari in 1983 , he was appointed as the acting village head by the sub-district government and then elected by villagers as the village head in 1986. He appointed his family friends in key posts in the village office (desa) such as village divisions (dusun), community and neighbourhood associations, irrigation associations (mitra cai), family welfare groups ( $\mathrm{PKK})$ and youth groups (karang taruna). During his tenure, Cece was entitled to 2 hectare of village land, ${ }^{8}$ which he rented out to his family friends as sharecroppers, and enjoyed privileged access to rural development

6 Elsewhere in Java, Husken (1991) showed that a tightly knit network of elite kin ties in a Central Javanese village allowed few village elites to establish a basis for controlling both local political power and economic resources.

7 Desa in Indonesian literary means 'village'. In day-to-day conversations at Namiwari, both village elites and ordinary villagers use desa to refer to the village office in general, which includes the building, staff and functions of village government.

8 Village officials have also similar privileged access to village land of smaller size. 
funds via the district government. To ensure the smooth flows of rural development funds, however, he had to pass government-imposed electoral thresholds for his village at elections by mobilizing his villagers and collecting votes for the government party Golkar. Power and benefits associated with the village head enabled him to accumulate capital. While in office, he purchased a mini bus, and began the operation of passenger transport. ${ }^{9}$ He hired friends of the family, including his village officials, to operate his passenger transportation business. Cece could also send his son Kartiwa to high school in Majalaya. ${ }^{10}$

In the Reformasi era, two major institutional changes were introduced to fix the broken linkage between village officials and ordinary villagers. First, following the implementation of Law No. 22/1999 on regional government, the village representative council (Badan Perwakilan Desa) was established in 2000 in Namiwari. The village council was expected to heed the voices of ordinary people and check the power of the village head. The village council regulation No. 1 says, 'the village council has the responsibility, function and authority to abide by the rules, to monitor village government, and to respond to villagers' needs'. The second significant institutional change was that, in 2003, as part of the conditionality of the World Bank's local governance reform project, the Bandung District government introduced a new mechanism of development planning called the Consultation on Planning of Annual Development Activities (МРКт). This consultation mechanism enabled villagers to have a say in prioritizing village development projects to be approved and funded by the district government. In other words, the newly introduced participatory planning promotes in theory direct participation by all villagers of all social differences in village development meetings and incorporates villagers' voices in the design and implementation of development projects. In theory, this new mechanism of participatory planning could thus curtail the existing practice of redistributing benefits to a minority of village elites and their friends in a clientelistic manner. ${ }^{11}$

These newly established institutions received mixed responses from village elites and ordinary villagers. For village elites, the village council performs its responsibility, and contributes to democracy. Although he moved to Namiwari relatively recently, Engkos was elected to the inaugural chair of the village

9 Over the years, he successfully added more vehicles and now owns six mini buses.

10 In Namiwari, high school education is considered as a high achievement. Because of his education background and his father's influence, Kartiwa was later elected as village head in 2002 at the age of forty.

For the mechanism of participatory planning, see Ito (2006). 
council. ${ }^{12}$ When asked about his institution's performance, he replied, 'Yes, we have democracy in the village. Although villagers' participation is not maximum, that is not a problem because their interests are now represented by the village council.' He believes that in the context of village democracy, while direct participation by villagers is preferable, it is perfectly substitutable for representation because the village council can deliberate on their behalf. For him, whether or not villagers participate and deliberate is not important.

When asked about the performance of the village council, however, a fairly significant number of villagers complained about a lack of any significant change in village government. They did not feel that the village office was any closer to them now. Instead, most villagers agree on the absence of the state in the village in the Reformasi era. They complain that district, sub-district, and village officials rarely 'come down' (turun) to their neighbourhoods to make contacts with them. ${ }^{13}$ Some villagers jokingly said, 'I do not even know who our village councillors are.' Suryadi, a village division head (kadus), offered a pessimistic observation on the performance of the village council. 'The village council is just a name. When the members are elected into office, they do not go anywhere. They just sit there. [The council] represents the voices of few. Villagers know the council members only by their names, and do not turn to them even when they want to express their concerns about village affairs. ${ }^{14}$

Similarly, ordinary villagers do not see the new mechanism of participatory planning as pro-poor. The village office (desa) claimed that in 2004 village development meetings were held and attended by many villagers. Yet of those villagers I interviewed almost no one - except villagers close to desa - knew about this participatory planning. In fact, desa neither made participatory planning known to villagers nor invited ordinary villagers to village development meetings. As in the past, invitation letters were sent only to recognized, male individuals - religious leaders, village elders and holders of village office. Moreover, village officials hardly appear to care about holding meetings at

12 Although he is not from the influential families, he was elected because of his progressive social activities in a non-governmental organization working on governance reform in Majalaya, his religious activities as a respected Islamic teacher, and his relatively higher educational background.

13 When village officials visit communities ( $\mathrm{RW}$ ) and neighbourhoods ( $\mathrm{RT}$ ), it is symbolically described as 'come down' (turun) to indicate the invisible hierarchy or divide between village officials and ordinary villagers.

Interview with village district head (kepala dusun), August 2006. 
times when villagers who work during the day could attend. Thus most villagers never participated in the participatory planning process nor brought their requests to desa.

Otong is an agricultural labourer and has not participated in village meetings before and after the introduction of the participatory planning mechanism. Otong found it rather hard to participate in formal village meetings because of his less than adequate educational background. Village meetings are normally conducted in Bahasa Indonesia, but Otong is unable to speak the official language because he did not graduate from elementary. Yet, this lack of qualifications does not appear to be the main obstacle. Otong further explains his non-participation: 'Generally, I do not disagree on decisions made by desa. What matters to me is results. I am fine as long as desa brings about the results of development.' Otong is concerned not with the rights and power that the new institutions might provide to ordinary villagers like him. He cares about what desa can offer. His social and economic situation forces him to value immediate benefits rather than status and rights to participate and deliberate. In other words, the everyday form of citizenship is tightly linked to political strategies that prioritize tangible benefits over abstract ideals.

This lack of participation by the rural poor, however, does not mean that they are not interested in development. Normally, they have a long wish list of things that they need to have improved. Some of the things on their list include building and improving village roads necessary to connect hard-to-reach hamlets to the main road for agricultural and commercial activities, improving the performance of village government services such as the issuance of the healthcare cards, improving irrigation to cope with droughts, or building houses for widows and Islamic schools for children.

Eti, a mother of ten children, moved to Namiwari in the early 199os. She has neither participated in village meetings nor brought any requests to desa for consideration. She and her husband do not have permanent jobs, but work as agricultural labourers. The wages for a day of work in rice paddy fields are barely enough for the family - 10,00o rupiah (one us dollar) for the husband and 6,500 rupiah ( 0.65 us dollar) for her. Rice can be harvested three times a year; they receive thirty kilograms of unhusked rice for each harvest. She brings their unhusked rice to a mill owned by former village head Cece. She pays two litres of rice for the service of milling 30 kilograms of rice. When asked why she avoids political engagement with desa, Eti ably explained:

...I feel ashamed of asking for help, and am afraid of village officials. They rarely come down to our hamlet; nor do I go up to desa. I just remain 
quiet rather than vocal (diam saja dari pada bilang). What is more important is that the stomach is filled and I sleep well (perut diisi tidur enak).

It is ironic that ordinary villagers do not see the village council or participatory planning as a democratic institution that can fix the broken linkage between village officials and ordinary villagers. Like Eti, the rural poor are working hard just to get by every day. Their concern is not democratic decision-making and their inclusion as rights-bearing citizens. They want tangible improvements of the quality of their lives, including better state services and a raise of the salary that they receive from their employers. The arenas of participation and deliberation are interpreted and guarded by intermediary powers who have linked village to state. From Eti's account, it is clear that the rural poor find little use in realizing their demands through political engagement with desa because desa refuses to interact with the rural poor on an equal footing and to come to terms with their real situation. For the rural poor, good or pro-poor officials are those who recognize them and make life a little easier for them. When rights and legal status inscribed in law do not enable the rural poor to improve their situations, the rural poor have more to expect from clientelistic exchanges with well-to-do neighbours and village elites.

Yet, when the needs of Namiwari's poorer villagers are not met, they do act independently of village officials. On a sunny morning in the monsoon season, over forty villagers, young and old, but mostly women, gathered to build a narrow paved path connecting a hamlet to the village main road. ${ }^{15}$ It was a community project organized by two well-to-do villagers, and implemented by neighbours to make it easy to transport harvested agricultural products to the markets and commute to central Majalaya. One of the well-off organizers was Sofyan, a retired former employee of the National Telecommunication Company (Telkom) who manages a public phone store (wartel) and a kindergarten in the village. The other organizer was Koko, a retired local official of Bandung's agricultural department who owns 4 hectare of land in a nearby sub-district. ${ }^{16}$ They run a village Quran reading group in their hamlet. Both organizers lamented that villagers had long wished this paved-path to be built by the village office, but that the latter done virtually nothing to improve the condition of their hamlet. They took the matter to their own hands. They supplied construction materials worth five million rupiah (five hundred us

\footnotetext{
15 A villager explained that men were absent because they were in the fields attending their crops.

16 In the late 196os, he was sent to study at Leiden, the Netherlands as part of his training by the Indonesian government.
} 
dollar), while their neighbours provided the labour. On that day, Eti and her husband also helped making the paved path. The efforts of the volunteers' work was rewarded by a hot meal prepared by women at the house of a village official. The meal was a local (Sundanese) dish - rice with cooked vegetables donated by the two organizers.

On the one hand, this kind of volunteerism can be seen as a sign of strong communal bonds and social capital. On the other hand, the tradition of community voluntarism has reified clientelistic, hierarchical relations. Since the colonial times, the village office has always relied on a combination of forced labour or community volunteerism to perform the operation of day-to-day village responsibilities, some of which fall into the realm of the government such as building village infrastructure and Independence Day celebrations. Today, village officials create the village budget based on the assumption that community volunteering is an important asset. The village budget is composed of three kinds of revenue: transfer from the district government, the village's own revenue and community volunteering (swadaya masyarakat) which is monetized. ${ }^{17}$ Because a larger share of community volunteering makes a good impression - cooperative, proactive and thick social capital - on the higher administration, desa makes efforts to mobilize volunteers by emphasizing the duties of villagers. In the eyes of desa, villagers are expected to perform certain duties as the recipient of development benefits. In this sense, the experience of everyday citizenship suggests that ordinary villagers might be low on rights but high on duties.

This high expectation of duties for ordinary villagers, contrasted with negligible emphasize of rights, has had significant influence over the actual practice of citizenship at the village level. The formal process and rights stipulated in the local regulations and guidelines for participatory planning are in practice interpreted to fit the village elites' perception of citizenship for the rural poor. There is a clear sense of class-based division between them in terms of who can and who cannot participate and deliberate in the decision-making process. Institutional changes have not made significant dents in the paternalistic attitude of village elites that goes back to colonial times and which was fostered through their intermediary role in making village communities eligible to the state as the eyes and ears of the state. Representative and participatory procedures appear to build on these earlier forms of patron - client relations. During informal conversations with village secretary Deden who hails from one of the influential family lineages in the village, he shared a phrase his father (former village head during the New Order era) used to remind himself of

17 In the 2004 budget, community volunteering accounted for $21.6 \%$ of the village budget. 
the role of the village office: 'Who are we? Whom do we serve? Where are we heading to? At the end of the day, we return to our original goal of serving for villagers.' Beneath the surface of political correctness, this phrase illuminates the invisible and indelible social division between village officials and ordinary villagers, closely aligned with the earlier forms of patron - client relations rooted in the particular trajectory of state formation in the context of Java.

\section{Conclusion}

This article has shown the local complexity of everyday citizenship in village Java. As seen above, citizenship is far from universal, and institutional configurations, rights, and legal status have had little impact on how the rural poor in Namiwari perceive, experience and practice citizenship in their everyday life. Rather, this article began with a premise that the tenuous linkages between villagers and the domain of the state suggest that the everyday form of citizenship that villagers experience is not bound by rights and legal status, but more tightly by personal relations with immediate power holders in their community. Thus, the everyday form of citizenship is tightly linked to political strategies of the rural poor that prioritize tangible benefits over abstract ideals. The rural poor employ various strategies and tactics of rights, voices and clientelistic protection because they experience citizenship in relations of power. Agricultural labourers Otong and Eti's disengagement from desa might appear to reflect simply a wrong understanding of citizenship rights and duties and even a lack of interest in democratic citizenship on their part.

Institutional change is not easily changing this layered form of citizenship because such mediated relations are a product of state - society interactions over a long period of time. Viewed from a vantage point of the historical development of state formation, the everyday form of village citizenship is rooted in the manner in which the budding colonial state expanded its power over villages. In colonial Java, because of the weak institutionalization of private property, it was not through landownership but rather through access to desa that rural elites established the basis of their power. In other words, state formation proceeded by co-opting village elites into desa while at the same time making the position of village head hereditary to ensure village elites' access to state resources in return for recognizing the state's legitimacy. It was thus through desa that village elites have accumulated rural power by serving as the interface between state and villagers, while rural power was not replaced by rationalizing state power but rather sedimented during the process of state formation. 
In postcolonial Indonesia, this dialectic relationship was further reinforced by rendering desa as the unit of political control through the standardization of village government structures. The imposition of the standardized form of village government did not replace the existing institutions of power, but created layers of power where new institutions of power sediment on the old layers of power. In a similar way, institutional change aimed at nurturing citizenship under the democratic reform of the Reformasi era must navigate through the layers of power accumulated and sedimented over the historical course of institutional change imposed from above. Thus, far from being straightforward and of institutional rationale, local politics is characterized by power relations, which in turn make the everyday form of citizenship that ordinary villagers experience as a relational process.

Citizenship in village Java is fluid and elusive. Therefore, the institutional view of citizenship falls short of capturing the still image of everyday citizenship. Instead of pursuing a universal shape of citizenship, this article has narrated and situated the stories of everyday citizenship experienced by the rural poor in village Java. While this article by no means rejects the normative attributes of citizenship as an important part of understanding citizenship, such a focus has failed to recognize the various ways in which people perceive, experience, and practice citizenship beyond the institutional domain. Rather, it is through working back from stories of people's experiences, this article suggests, that we can capture the everyday form of citizenship from the vantage point of ordinary citizens.

\section{References}

Agrawal, A. (2001). State formation in community places? Decentralization of control over forests in the Kumaon Himalaya, India. The Journal of Asian Studies, 6o(1), 9-40.

Antlov, Hans. (1995). Exemplary Centre, Administrative Periphery: Rural Leadership and the New Order on Java. Surry: Curzon.

Bierschenk, T. and J.P. Olivier de Sardan. (2003). Powers in the Village: Rural Benin Between Democratisation and Decentralisation. Africa, 73(2), 145-173.

Breman, Jan. 1980. The Village on Java and the Early-Colonial State. Rotterdam: Erasmus University Rotterdam Comparative Asian Studies Programme.

Chatterjee, P. (2004). The Politics of the Governed: Reflections on Popular Politics in Most of the World. New York: Columbia University Press.

Cornwall, A., S. Robins and B. Von Lieres. (2011). States of Citizenship: Contexts and Cultures of Public Engagement and Citizen Action. IDS Working Paper 363 . 
Edi, J. and A. Setianingtias. (2007). Donor proliferation and donor coordination Indonesia: the case of governance reform. Paper prepared for Centre for the Future State, Institute of Development Studies, University of Sussex.

Hart, G. (1989). Agrarian change in the context of state patronage. In G. Hart, A. Turton and B. White, (Eds.), Agrarian transformations: local processes and the state in Southeast Asia (pp. 31-49). Berkeley, CA: University of California Press.

Hirsh, P. (1989). The state in the village: interpreting rural development in Thailand. Development and Change, 20(1), 35-56.

Holston, J. (2008). Insurgent citizenship: disjunctions of democracy and modernity in Brazil. Princeton: Princeton University Press.

Husken, F. (1991). Power, property and parentage in a Central Javanese Village. In F. Husken and J. Kemp (Eds.), Cognation and social organization in Southeast Asia. Leiden: KITLV Press.

Husken, F. and B. White. (1989). Java: Social Differentiation, Food Production, and Agrarian Control. In G. Hart, A. Turton, and B. White (Eds.), Agrarian transformations: local processes and the state in Southeast Asia (pp. 235-265). Berkeley, CA: University of California Press.

Ito, T. (2006). The Dynamics of Local Governance Reform in Decentralizing Indonesia: Participatory Planning and Village Empowerment in Bandung, West Java. Asian and African Area Studies, 5(2), 137-183.

Ito, T. (2011). Historicizing the power of civil society: a perspective from decentralization in Indonesia. Journal of Peasant Studies, 38(2), 413-433.

Kano, H. (1977). Land tenure system and the desa community in nineteenth century Java, Tokyo: Institute of Developing Economies.

van Klinken, G. (2009). Patronage democracy in provincial Indonesia. In O. Tornquist, N. Webster, and K. Stokke (Eds.), Rethinking popular representation (pp. 141-159). Hampshire: Palgrave Macmillan.

Lund, C. (2011). Property and citizenship: conceptually connecting land rights and belonging in Africa. Africa Spectrum, 46(3), 71-75.

Mamdani, M. (1996). Citizen and subject: contemporary Africa and the legacy of late colonialism. Princeton: Princeton University Press.

Matsuo, H. (1970). The development of Javanese cotton industry. Tokyo: Institute of Developing Economies.

Onghokham. (1975). The residency of Madiun: pryayi and peasant in the nineteenth century. Ph.D. Dissertation. Yale University.

Robins, S., A. Cornwall and B. von Lieres. (2008). Rethinking citizenship in the postcoloy. Third World Quarterly, 29(6), 1069-1086.

Schiller, J. (1996). Developing Jepara in New Order Indonesia. Clayton: Monash Asia Institute. 
Schulte Nordholt, H. 2005. Decentralisation in Indonesia: less state, more democracy? In J. Harriss, K. Stokke and O. Tornquist, eds. Politicising democracy: the new local politics of democratisation. Hampshire: Palgrave Macmillan.

Scott, J. (1972). Patron-client politics and political change in Southeast Asia. American Political Science Review, 66(1), 91-113.

Tilly, C. (2004). Contention and democracy in Europe, 1650-2000. New York: Cambridge University Press. 


\title{
Elections and Emerging Citizenship in Cambodia
}

\author{
Astrid Norén-Nilsson
}

At an informal lunch in the company of Cambodian friends in Phnom Penh, our host Sambath surprised us by showing a video of opposition leader Sam Rainsy's return to the Cambodian capital a few days earlier. After four years in self-imposed exile, Sam Rainsy had returned only nine days ahead of the July 2013 national elections, as president of the newly formed Cambodia National Rescue Party (CNRP). The video documented the fervour of the welcome offered by a sea of supporters, lining the streets from Pochentong Airport across the city to the so-called Freedom Park, the designated spot for demonstrations. What surprised our lunch company was not the (now familiar) images themselves, but rather that the video was being shown at the home of a security guard at Phnom Penh's O'Russey market. The guard, who was officially required to be a member of the incumbent Cambodian People's Party (CPP) and had the task of monitoring the political allegiance of market vendors, had decided to purchase the DVD from one of these vendors regardless, seemingly betraying his political masters. In this chapter, I will reflect on what the security guard's actions may imply about changing notions of citizenship in contemporary Cambodia.

The national elections held on 28 July 2013 were Cambodia's fifth since the reintroduction of a multiparty democratic system, prepared for by the 1991 Paris Peace Agreements (PPA). The Cambodian People's Party (CPP) and its precursor, the Kampuchean People's Revolutionary Party (KPRP), have dominated Cambodian politics ever since 1979, from a one-party socialist republic through to the transition to today's multiparty liberal democratic state of the Kingdom of Cambodia (KOC, 1993-). Though royalist party FUNCINPEC won the first multiparty elections in 1993, the CPP has seen successive electoral triumphs ever since, steadily increasing its vote from $38.2 \%$ in 1993 , to $41.4 \%$ in 1998 , to $47.3 \%$ in 2003 and to $58.1 \%$ in 2008 , while heading successive coalition governments with FUNCINPEC. Having consolidated its power to what seemed an unprecedented extent, the CPP under the leadership of Prime Minister Hun Sen appeared poised to enjoy a landslide victory in the 2013 national elections. The official election results, therefore, took most observers by surprise: the CPP suffered a sharp drop in support, winning only $48.83 \%$ of the vote, while the CNRP, a newly formed coalition between the two main opposition parties, came in a close second at $44.46 \%$. The CNRP has 
refused to acknowledge the official election results, and claims to be the real winner of the elections.

While it is clear that Cambodia is going through some major social and political changes at the moment, their nature and direction remain elusive. Strikingly, they appear to be intimately tied up with popular living conditions and access to resources. The Cambodian state is structured by interlocking pyramids of competing patron - client networks ( $k$ hsae), and political power stems from the ability to fulfil the material aspirations of clients (Heder 1995: 425-429). Since economic liberalization in the late 1980s, a hybrid neopatrimonial administration has emerged, whereby informal patron - client power dynamics have mixed with formal bureaucratic power. Power is highly centralized to political figures and central ministries exercising control over resources, but is maintained by political support from rural bases secured through the distribution of material gifts and physical infrastructure (Pak et al., 2007: 57-58). The CPP has relied on such gift-giving practices throughout the era of multiparty democracy as a defining characteristic of the party's political project. This is integral to shoring up popular allegiance and electoral support. The democratic opposition, on the other hand, has campaigned on an anti-corruption agenda, similar to that of many other Southeast Asian democratic parties. They consider gift-giving practices as vote-buying, and use rights-based language to challenge these.

The legitimacy of these competing models of provision in Cambodia remains poorly understood. Whilst a discourse of rights is firmly rooted, it is unclear whether voters are now challenging the current political economic order by claiming their right to resources, or are simply seeking new avenues to access resources - irrespective of the terms. This chapter attempts to approach the question of whether, and if so, how, the electoral surge of the opposition relates to the legitimacy of different models of provision. In doing so, it takes up this volume's invitation to examine how the institution of electoral democracy relates to the politics of patronage and clientelism. More specifically, it questions whether an 'unremitting preference of voters for clientelistic exchanges' such as that described in the introductory chapter, can be identified, and to what extent political clientelism can be understood as an alternative form of democratic accountability. I start by examining competing elite-defined conceptualizations of democratic citizenship relating to clientelistic practices and a competing rights agenda, and then reflect upon how such ideas played out in the 2013 national elections. Tracing their role in the political parties' campaign discourses, strategies and post-election analyses, I draw on ethnographic data to offer an account of corresponding popular values and practices. I then assess what this tentatively says about emerging forms of citizenship in Cambodia. 


\section{Emerging Forms of Citizenship in Cambodia}

In Cambodia, just as in many other Southeast Asian countries, the notion of citizenship (sânheat) carries little significance beyond that of designating one's legal status. A far more central notion in domestic political discourse is that of the nation (cheat), posited on the presumption of a shared identity to which competing political values are attached, which generally outshines and, often, stands in outright conflict with the legalistic notion of citizenship. ${ }^{1} \mathrm{~A}$ range of competing models of the 'ideal nation' - outlining particular relations between the political leadership and the general populace, all envisaged as 'democracy' that date back to before the 1953 achievement of national independence, are propagated by political parties. A defining characteristic of these different models is the terms of access to resources through which the populace is to obtain property, security and welfare. By studying the everyday practices, values and attitudes that characterize concrete interactions between citizens and the public authorities, we can establish a fresh perspective for conceptualizing the transforming legitimacy of different models of provision, the ideal political order and, by extension, emerging forms of Cambodian citizenship.

In Cambodian political discourse, election promises have been understood to centre on buzzwords such as 'democracy', 'human rights', and 'justice' often overlapping between parties and seemingly void of meaning (Hughes 2002: 169). This scenario has baffled observers, who expected electoral competitors to phrase their programmes in the language of ideology. ${ }^{2}$ Yet arguably, political competition is bound up with each party or party leader declaring to be the genuine representative of an idealized imagining of the Cambodian nation. In seeking to forge exclusive links between themselves and the nation, political actors have offered solutions centred on the provision of welfare and access to state resources - each bestowing a different meaning to notions like democracy. Interpretations of citizenship, as practiced and perceived, are tied to such wider ideas and are not solely confined to the individualistic rightsclaiming typically celebrated in citizenship literature.

1 The latter case is exemplified by the political party The Cambodian Citizenship Party (Konâbâk Sânheat Kampuchea) which competed in the 2013 national elections. Purporting to represent the interests of all those holding Cambodian citizenship - including those of Vietnamese ethnicity - it was therefore primarily considered to be pro-Vietnamese.

2 Joakim Öjendal and Mona Lilja (2009:303) note that 'the idea that the existence of competing party ideologies is one of the cornerstones of liberal democracy has not taken root in Cambodian society'. 
Partha Chatterjee has influentially argued that we need to reconceptualize how developmental states and their populations in the Global South interact. Citizens in the postcolonial world primarily aspire to access state resources little does it matter that these are typically granted as 'exceptional entitlements' instead of full citizenship rights (Chatterjee 2004, 2011). Employing Chatterjee's notion of 'political society' as the sphere where such interactions take place, Andrew Walker (2012) has attempted to redefine rural political behaviour in Thailand which, like its neighbour Cambodia, is set in a clientelist, gift-giving economy. Walker argues that Thai rural voters are informed by local values, which recast practices typically dismissed under the label of 'clientelism' as important characteristics of legitimate political power. Applied to Cambodia, the notion of 'political society' adequately recognizes the centrality of access to benefits, welfare and state resources for emerging concepts of citizenship and democracy. Yet, the Cambodian case also challenges the certainty that populations across the postcolonial world are content with exceptional access to resources - such as the presentation of gifts - rather than full citizenship rights.

A sharp dichotomy between a Western rights-based type of citizenship and a postcolonial one based on patronage does not only defy empirical evidence, but also runs the risk of 'othering' Cambodian forms of citizenship as necessarily clientelist. Schaffar (Chapter 10 in this volume) has identified similar trends in the case of Thailand. Crucially, popular access to benefits, welfare and resources, which patterns of citizenship revolve around, is often negotiated not between populations and states, but between the former and 'twilight institutions' (coined so by Christian Lund) - organizations that are not legally recognized as part of the state but nonetheless exercise public authority. These groups of institutions are said to operate in the 'twilight' between state and society and the public and private spheres. Public authority is here 'processually' formed in the sense that when 'an institution authorizes, sanctions, or validates certain rights, the respect or observance of these rights by people... constitutes recognition of the authority of that particular institution' (Lund 2006: 675). Recognition or rejection takes place in day-to-day social encounters between various forms of public authority and ordinary people. Lund, therefore, invites us to approach the phenomenon of public authority from the perspective of how particular issues (such as security, justice, development or taxation) are governed by a variety of actors, rather than to see these as stemming from the single source of the state (Lund 2006: 682). In Cambodia, twilight institutions are crucial for providing citizens with resources such as security, welfare and property. 
Studying changing everyday values and practices in encounters with public authorities, often of a twilight kind, can therefore instruct us in several ways. These changes can be read as a transforming set of popular political values. ${ }^{3}$ This sheds light not only on the legitimacy of Cambodia's current political economic order, but also of various elite political projects, Cambodian state - society relations in general, and the ideal model of relations with political leadership as envisaged by its populace. Interactions between ordinary people and public authorities also inform us about emerging notions of citizenship - giving us an understanding of whether the populace is primarily seeking to maximise what the state can provide, or if there is a desire to formalize this access to resources. As people in twilight institutions move in and out of state and society, and between public and private spheres, these interactions offer an insight into ongoing negotiations for different models of resource provision.

\section{The Politics of Gift-Giving and Democratic Citizenship in Cambodia}

The provision of benefits and resources to the populace has been central to historical conceptualizations of legitimate power in Cambodia. In the era of multiparty politics, contemporary political party projects have reinvented such historically inherited ideas inside the framework of a radically new political economy, mobilizing them to their own political ends. Though democratic legitimizations in Cambodia are typically understood incorrectly as external in nature, these ideas have been at the foundation of competing political projects phrased in the language of democracy - intended for and vocally propagated to the domestic population. Ideas of how resources are to be distributed to the population are central to competing domestic discourses of democracy in varying ways.

The incumbent Cambodian People's Party (CPP) has relied on gift-giving as the backbone of their domination of Cambodian politics throughout the era of multiparty democracy. In CPP discourse and practice, social and economic development is presented in the form of gift-giving rather than in terms of state accountability associated with taxation. These gift-giving practices

3 In the context of Thailand, Andrew Walker (2008:87) has referred to such local values that inform the everyday politics of elections as making up a 'rural constitution': an uncodified set of political values which 'regulates, constrains, and legitimates the exercise of political power'. 
have inserted patronage logics into post-reform Cambodia's democratic system in complex ways (Hughes 2006), with much service provision taking place through twilight institutions. CPP working groups (krom kar ngear) are in charge of distributing donations from the party to rural communities, what is known as the choh moulothan ('going down to the base') strategy. This strategy originated in the 1980s, when party cadres brought pro-socialist, anti-Khmer Rouge propaganda to the grassroots. However, when the multiparty democratic system was introduced, its meaning changed to the bringing of donations, which were understood to increase in the event of CPP electoral victory (Un 2005:221-222). Since the working groups are directly associated with voter mobilization at the local level, this has been a crucial strategy for ensuring the CPP's continued hold on power. ${ }^{4}$ The twilight character of the CPP working groups is clearly evident here: they present developmental assistance as coming from the party and sponsoring business partners rather than from the state, and yet have come to constitute an important channel of provision substituting for the state in rural areas. Their achievements are frequently broadcast in the media, but they hold no civic accountability and there is no publicly accessible documentation of their work.

Another important channel of provision is the Cambodian Red Cross (Kakâbat Krohom Kampuchea), headed by First Lady Bun Rany. The CRC has, since its beginning, enjoyed unique recognition from the government as its auxiliary and a mandate as a quasi-governmental organization, basing its work on the help of volunteers to distribute aid to victims of natural disasters, soldiers, orphans, et cetera (Men and Dickens 2005:31). ${ }^{5}$ Under the presidency of Bun Rany, the CRC has become increasingly publicly exalted, in ways that emphasize the distinctly royal overtones that her work for this (originally royal) organization carries. As head of the CRC, Bun Rany's association with caretaking and healing intersects with the conceptual and historical role of royals on a number of levels. ${ }^{6}$ Paralleling the consolidation of power by Hun Sen and

4 Each of Cambodia's districts has a working group. In this top-down structure, a deputy prime minister is responsible for the province level, a minister or secretary of state (ss) for the district level, an ss or ministry director general for the commune level, and a ministry director (or equivalent rank) for the village level. The working group typically visits their district on the weekend, together with sponsoring business partners, to offer developmental assistance.

5 Originally founded in February 1955 as the Khmer Red Cross Society (Samokom Cheat Kakâbat Krohom Khmer), the organization was renamed the Cambodian Red Cross (CRC) in 1979.

6 Bun Rany replaced Princess Norodom Marie, then spouse of FUNCIN PEC party leader Prince Norodom Ranariddh, as president of the Red Cross in 1998, following the July 1997 events which ousted Ranariddh from his post as first prime minister. On the historical association between kingship and healing, see Thompson (2004). 
his network, her presidency has firmly integrated practices of gift-giving into personalized claims to embody nation-building in line with historical conceptualizations of kingship.

These strategies of provision are an integral part of the political project, democratic vision, and legitimizing discourse propagated by the CPP to the domestic population. The CPP-led regime, under Prime Minister Hun Sen, is typically understood not to have put forth a self-identified political identity to fill the shoes of the previous Marxist-Leninist identity that was pushed aside with Hun Sen's rise within the party - when pragmatic technocrats came to replace Marxist-Leninist ideologues in government (see, for example, Slocomb 2006:395). Yet, next to appeals for liberal democracy, Prime Minister Hun Sen claims 'populism' to be the political identity of his regime, and has advanced the concept of 'people's democracy' (pracheathipatey pracheachon) as the base of CPP policies and his own political thinking. ${ }^{7}$ Hun Sen has provided the following definition of 'people's democracy':

What I try to do is to provide the best service for the people, the majority of the people who are poor. When we started the struggle to liberate the citizenry, we targeted the people to make the majority of the people rich after the genocidal regime. With bare hands we made sure that people would start living again and enjoy better living conditions. Our policy towards farmers is that we have never claimed tax from them. I have told my colleagues not only not to tax farmers, but also that we must intervene to help the people. We have to build infrastructure for the people, including irrigation, roads, canals, houses, schools, and clinics.... These are some of the points related to the basis of our policies, that is, people's democracy. HUN SEN, interview by the author, 29 August 2011

The notion of 'people's democracy' makes claims of popular representation through a truly national form of democracy, which deviates from the liberal democratic model. First elaborated by Prime Minister Hun Sen during the People's Republic of Kampuchea (1979-1989), it can be understood to provide a discursive and conceptual bridge in regime identity from the one-party socialist republic of the PRK to the KOC era (1993-) of capitalist transformation within a multiparty democratic framework. 'People's democracy' in the кос

7 This has been overlooked by existing scholarship, despite the recurrence of these notions in public discourse (see, for example, Hun 2005, 2007).

8 Hun Sen first developed the notion in his doctoral thesis 'Lokkhânah pises day laek nei domnaurkar padevott Kampuchea' (The Special Characteristics of the Progress of the Cambodian Revolution), which written during the PRK-era, discussed the evolution of Cambodian 
has been reoriented to frame the novel regime practices - centred around giftgiving - associated with the transformation into a new political and economic system within the post-1993 framework. ${ }^{9}$ Democracy is made out to form a continuity - linking past and present regime practices - even though its PRKera Marxist-Leninist contents have been wiped away. Portrayed as the very foundation of the CPP-led regime's political agenda, gift-giving practices have thereby become central to the regime's version of democracy as propagated to the general public.

The notion of legitimate leadership as residing in the ability to provide for the well-being of the population has also been constructed by a second main political camp in the KOC - the royalists. Entangled with historical conceptualizations of Khmer Buddhist kingship (see Thompson 2004), this notion was given its modern shape in Prince Sihanouk's 'People's Socialist Community' (Sangkum Reastr Niyum 1955-70); Cambodia's first post-independence regime which assumed a rosy glow in the post-1993 reunited kingdom. This was not solely a historical legacy easily appropriated by the C PP (cf. Frings 1995; Hughes 2006), but was also made a cornerstone of the post-1993 reinvention of royalist democracy. Under the label of 'the social opening', identified by long-term FUNCINPEC leader Prince Norodom Ranariddh as a doctrinal basis of 'Cambodian democracy' during the Sangkum, royal provision for and protection of the population remained central to Ranariddh's vision of what democracy must mean in the KOC (Norodom 1998:133). The social opening was displayed in how FUNCINPEC engaged in development activities, including practices of gift-giving, which were framed as directly modelled on Sihanouk's activities in the past. Yet, although the royalists propagated a pleasant vision of royalist democracy, they lacked the material base to put this into practice. Seen from this perspective, FUNCINPEC'S outmanoeuvring by the CPP as providers of benefits not only stripped them of the gratitude of beneficiaries, but also resulted in a 'democratic deficit' for the royalists. The long and steady decay of FUNCINPEC, since the party's 1993 electoral victory, appears to have reached its end-point with the 2013 elections when, for the first time, the party failed to win any seats.

The main challenge to the CPP model of provision has come from a third group of party political actors, the Democrats. This group considers provision

regimes and state - society relations since the French protectorate onwards. In this re-reading of Cambodian history using Marxist-Leninist concepts and categories, democracy was firmly integrated as part of revolutionary history as the unchanging goal of 13 decades of a Cambodian revolutionary quest. Parts of the thesis were published as 13 tusevott nei domnaur Kampuchea [13 Decades of Cambodia's Evolution], Hun (1991).

9 Hughes (2006:469) traces the practice of gift-giving to the beginning of Cambodia's political and economic reform process, around 1989. 
for popular needs primarily in terms of the satisfaction of the 'people's will', which the Cambodian democratic project has posited as its very raison d'être. Democrats have, therefore, engaged in a range of strategies to identify the socio-economic needs of the people by learning about their living conditions what can be understood as their fundamental imagining of how to democratically relate to the nation. To trigger change, democrat leaders would have to insert themselves into ordinary people's realities, allowing them to channel their demands and thus empower them. The purpose was to raise all members of society to equal status as rights-bearing citizens, considered to be a precondition for true democracy. These strategies have been all the more important since the Cambodian democratic project's claim to popular representation has been partly contradicted throughout its history by its elite-driven nature, entailing fundamental problems of connecting with the rural masses it has purported to represent (cf. Chandler, 1991:30; Corfield 1994:10-11; Hughes 2009:35). Alienated from the electorate by their elite and transnational backgrounds, it has been deeply problematic for KOC-era Democrats that the CPP's penetration to the local level has given the party the near-exclusive ability to identify and satisfy people's actual needs. This manifests the closeness, or even intersection, of the CPP and democratic discourses, resulting from their shared focus on provision.

The Democrats imagine democracy to transcend the implementation of an ideology or doctrine, and to be concerned with more basic questions of the relationship between the people and the political leadership. The terms by which the population accesses resources has been highlighted as paramount. CNRP President Sam Rainsy and his supporters have charged that the CPP-led government pursues a particular strategy to control the populace, summed up as the 'three k's': khlach (fear), khlean (hunger), and khlov (ignorance)..$^{10}$

Under the rubric of khlean (hunger), Sam Rainsy has accused the CPP of maintaining a 'link of subjection' with the people through their gift-giving practices:

10 The 'three k' has been identified by some as a Khmer Rouge strategy to ensure complete control of the populace. Sam Rainsy and other Democrats have repeatedly charged that the CPP regime purposely emulates this model. In his 2008 autobiography, Sam Rainsy thus identifies, in contemporary Cambodia, the presence of widespread fear, through CPP-led politically motivated intimidation, threats and constraint forming a weapon of political domination; hunger, charging that the CPP prefers to maintain a link of subjection' with the people by offering food donations rather than creating viable jobs; and ignorance, charging that the CPP does not invest sufficiently in education, purposely resulting in continued high levels of rural illiteracy and the absence of social and political conscience and critical thought Sam 2008: 228-9). 
Khlean - [under Khmer Rouge] they [the people] would die of starvation. But Hun Sen's people are making people poor. They lose their land, their fishing zone, [they have] poor salaries like factory workers, with commercial monopolies causing an increase in the price of commodities. This is the new system to control the people through the economy, through the basic needs of survival. Then they depend on donations, on handouts, and forget the national issues. This is why the fight against corruption, the fight to improve living conditions, to allow people to live with job creation, [so that] you depend on your salary, and not on handouts - all these are interrelated. Then the human spirit can thrive because you are not prisoner of your stomach.

SAM RAINSY, interview by the author, 24 April 2012

Effectuating social and political change requires a change from the prevailing 'beggar mentality' to a newly-established 'culture of citizenship', according to Sam Rainsy. He felt that the citizenry would free themselves of the blurred vision that the policies of khlach, khlean, khlov has imposed on them, and clearly perceive of their interests and rights as citizens, if only they would be allowed to develop critical thinking. Democrat leaders routinely express their belief in the necessity of profound changes in Cambodian popular mentality to achieve this culture of citizenship - often invoking Western models - as seen in the following quotes:

To change the system peacefully, you need to change the mentality of the people. In Cambodia, it is like the traditional, ancient states. We need to educate and say - you are the people, the masters of the country's destiny. Every day, I have to educate the people that I meet to make them change the mentality. If we speak about democracy, they understand nothing. That is my opinion - we need to change people's mentality and especially that of the youth. We need to educate them about anticorruption, how to fulfil their tasks as citizens. I have the technique, I am a pedagogue.

HO VANN, interview by the author, 26 March 2010

I think Cambodian people are learning what democracy is all about. We have the exposure to Western thinking and try to introduce it to our members. Then it is up to them to decide, not us.

SON CHHAY, interview by the author, 23 March 2010

Envisaging democratization in strongly didactic terms as a change of mentality is widespread in regional democratising contexts. Often, elites draw on 
Western democratic theory to insert new notions of citizenship in order to remould the relationship between populations and the state. In Thailand, such concepts came to underpin what Michael Connors (2003) has characterized as 'democrasubjection', referring to the employment of elite-defined liberal democracy as a disciplining practice to secure hegemony over the population. Although in Cambodia there was never one hegemonic, national ideology of democracy such as that which Connors identifies in Thailand, one can certainly see similarities with the project of Cambodian self-identified democrats. The elites are needed to steer this process of a change in mentality, and they continue to define what is meant by the 'common good', which all ideal citizens are envisaged to work towards. In this sense, democratic elites primarily represent a 'future nation' which they have actively tried to create and shape, rather than one that already exists. In Thailand, elites share an interpretation of popular (rural) political behaviour as dictated by money politics, and therefore refuse to recognize the democratic legitimacy of the electoral choices made by the general populace. ${ }^{11}$ Likewise, in Cambodia, democrats believe that the vision of the general populace is blurred by the 'three $\mathrm{k}$ ', which leads to profoundly illegitimate electoral outcomes. By contrast, however, Cambodian democrats have put their efforts into moulding rural political choices through delegitimizing clientelistic exchanges in the eyes of the electorate.

Though purporting to represent grassroots concerns, these competing democratic discourses were articulated from above. The nature of Cambodian democracy and its appropriate model of provision has largely remained an intra-elite debate - a major reason for this possibly being the sheer ignorance of the elite regarding the political preferences of the electorate. Caroline Hughes (2001:298) has drawn attention to the social and political opacity of Cambodia's post-war rural electoral heartland' and refers to Cambodian voters as the 'silenced majority'. She highlights that 'very little is known' about the demographics of Cambodian voter preferences, so that 'political parties continue to operate blindly in this key site of democratic politics'. Ever since the first democratic elections in 1993, voters have been encouraged to not speak openly about their political preferences (Hughes 2001:303-304). Studying popular perceptions and practices of accessing state resources, therefore, sheds muchneeded light on the levels of legitimacy that elite discourses of democracy hold

11 Walker (2012:91) summarizes this model of rural political behaviour as having three components: that rural voters have little interest in policy issues and vote for those who can deliver immediate benefits; that they are readily swayed by vote-buying; and that electoral mobilization takes place through hierarchical ties of patronage whereby local figures deliver votes to political masters. 
in society, and the competing understandings, reinterpretations and or renegotiations there. These debates are central to the contested nature of emerging forms of democratic citizenship in Cambodia.

\section{July 2013 Elections}

The manner of resource distribution has thus been the defining feature to distinguish competing political party projects throughout the multiparty democratic era, pitting the CPP and royalist championing of gift-giving practices against the condemnation of this by the democratic opposition parties. Although this issue has had a constant presence, it was called into question more aggressively than ever before during the campaign for the July 2013 national elections. During this time, the CNRP made a concerted effort to bring down the legitimacy of CPP gift-giving practices, which they perceived as votebuying. In their analysis, CNRP leaders later credited this conscious strategy with their subsequent strong gains (Mu Sochua, interview by the author, 20 November 2013).

Most plainly, the effort to discredit gift-giving practices was expressed in the ubiquitous CNRP campaign slogan: 'My gasoline, my motorbike, my money, my morale, save my nation. Change! Change! Change!' This slogan referenced how CNRP campaign rally participants would ride their own motorbikes, spending their own hard-earned money on gasoline, that way expressing their unselfish commitment towards the nation. Its obvious target was the CPP rally participants, who conversely received money for their participation, and typically toured on large pick-up trucks provided by the party, which were gaily embellished with coloured lights and equipped with TV screens and bombastic dance music. This slogan was printed on stickers and distributed to participants in the CNRP campaign rallies, many of whom plastered them onto their motorbikes. Its power lay in tying the rejection of gift-giving practices to a general call for change. Change was portrayed as inherently linked to, or directly constituted by, citizens taking pride in spending their own resources for acting on their political conscience, rather than offering political allegiance in return for financial and material support.

By contrast, the CPP's main campaign slogan was a direct appeal for personal loyalty to Prime Minister Hun Sen, and was phrased: 'If you love, if you pity, if you like, if you trust Samdech Hun Sen, vote for the Cambodian People's Party. Voting for the Cambodian People's Party means voting for yourself.' Equally ubiquitous, this slogan was put on campaign posters with a smiling prime minister spread across the country. Expressing the personalization of 
power to the prime minister at the expense of the CPP as a party, this slogan cast service provision as directly dependent on the personal intervention of the prime minister, who would see to it that all those who chose to place their trust in him were provided for.

The CNRP slogan discredited, in particular, the CPP practice of offering campaign rally participants financial compensation, amounting to five us dollar per day. CNRP campaign discourse also questioned CPP campaign funding in general, charging that it came from tax collection appropriated by the CPP. The typical CNRP narrative stated that rally participants collected the daily five US dollar for campaigning for the CPP, only to bring this money to the CNRP donation boxes. In their campaign discourse, the CNRP consistently encouraged the electorate to receive any gifts offered by the CPP, but to stop short of actually voting for the party. The CNRP's routine encouragement of voters to accept whatever they could receive from the CPP reflected a willingness to accept the electorate's dependence on gift-giving rather than to condemn it, but to transform the act of receiving gifts to a subversive one, loaded with the force of covert rejection.

The CNRP, on the other hand, collected donations from campaign rally participants through donation boxes in on-site tents at Freedom Park, the Phnom Penh campaign rally point. Campaign participants were encouraged to make donations in the form of money, food, or any other materials they deemed useful. According to CNRP lawmaker-elect Mu Sochua, the party typically collected 30,000 us dollar per rally day through these boxes $(\mathrm{Mu}$ Sochua, interview by the author, 20 November 2013). The CNRP also pleaded for financial contributions through radio broadcasts stating their account number. The names of donors were then publicly acknowledged on Facebook.

While the CNRP put great emphasis on discrediting the practice of financially compensating campaign rally participants, the party did offer forms of financial support to campaign participants. The CNRP covered transportation for participants travelling from provinces to Phnom Penh's Freedom Park, and provided them with lunch and dinner during their first day of participation. The CNRP also mobilized their funds - much of it donated by Cambodian overseas supporters - to support particular causes, such as supporting those locked in ongoing conflicts with the government. Examples include the victims of land evictions in Phnom Penh's Borey Keila and Boeung Kak communities as well as those injured at post-election demonstration incidents at Kbal Thnal and Steung Meanchey in the suburbs of Phnom Penh. The CNRP also supported communities hit by flooding throughout the country in August to September 2013, and made financial donations to villagers for the Buddhist gift-giving ceremony of Kathen during this period. According to the CNRP, 
these gift-giving practices differed from those of the CPP because target villages were not selected on the basis of whether the party headed the commune, and also that membership of the CNRP was not a criterion to receive gifts. Rather, donations were given to villages with a strong link between the party and the villagers through active MPs. Party representatives in villages would contact the party headquarters when help was required, and the communities most affected would be singled out for support. Whilst the terms of gift-giving were thus said to differ from those of the CPP, the ability to provide was arguably an important contributing cause for the CNRP's electoral gains. Just as CNRP leaders later claimed that the critique of CPP gift-giving practices was prompted by their strong surge in electoral support, they equally acknowledged their increased ability to assist voters through local networks as a crucial element (Mu Sochua, interview by the author, 20 November 2013).

A main factor believed to have contributed decisively to the popularity of the CNRP was the seven-point policy programme that they campaigned on, which focused on raising living standards. The CNRP pledged to fund this programme by using existing domestic revenue and cutting back on corruption to re-appropriate missing revenue from taxes, customs and land concessions. An important part of the programme centred on promising a personal income, with three out of seven points guaranteeing minimum salaries and pensions. Two more points concerned the provision of social benefits, in the form of free healthcare and education, whilst a further two established a minimum price for rice and pledged to lower the prices of oil, fertilizer, electricity and loan interest rates:

1. A monthly pension for individuals aged sixty-five years and older of 40,000 riels ( 10 us dollar).

2. A minimum monthly wage for workers of 600,000 riels (150 Us dollar).

3. A minimum monthly salary for civil servants of $1,000,000$ riels ( 250 US dollar).

4. Farmers guaranteed to receive at least 1,00o riels per kilogram of rice (o.25 Us dollar).

5. Free medical care for the poor.

6. Equal education opportunities and proper employment for youths.

7. A reduction of the prices of oil, fertilisers, electricity and interest rates on loans.

The seven points can be read as promises to secure voters' personal income and access to state resources as a matter of right, rather than as ad hoc gifts. In this sense, they promised to formalize the access to state resources. 
An equally plausible alternative reading is that the seven points guaranteed to increase voters' income, which arguably took precedence over the discussion of whether this was granted as a right rather than an entitlement. Read in this way, this policy platform primarily constituted a pledge to improve voters' personal economy.

From the perspective of the CNRP leadership, their dramatic electoral gains reflected a mixture of both motivations. While gift-giving practices were recognized as forming a part of domestic political culture, the CNRP maintained that the CPP's mistake was to have a complete reliance on such practices without realising that voters were angered by the vast income discrepancy that had developed. Voters would accept gifts if offered, but they were not sufficient to satisfy them. The CNRP aimed to mobilize this existing discontent and transform it into a larger political analysis to eventually make people renounce gift-giving practices and the current economic order, thus planting the seeds of a new political conscience. This was phrased in the language of rights. Rather than simply encouraging the electorate to vote for the CNRP, the party encouraged the electorate to 'vote for your right'. Their subsequent surge in popularity was therefore perceived to derive from a combination of the yearning to secure better living standards and a change of political consciousness. Initially, in this analysis, supporters were motivated by an attempt to secure more personal income, such as those promised by the seven points. Once involved in the CNRP campaign, however, this initial motivation would transform into a changed political consciousness, whereby political activity and participation would be prized over the passive receipt of benefits (Mu Sochua, interview by the author, 20 November 2013).

From the perspective of the CPP, however, their sharp decline in electoral support was interpreted very differently. They believed voters had developed an indifferent attitude towards the CPP's provision of public infrastructure such as roads, bridges and hospitals, which were now starting to be taken for granted. Provisions of this kind quickly became part of everyday life, and voters had forgotten where the initiative and funding for local infrastructure originally came from. A vote for the CNRP, meanwhile, was understood as a vote to obtain more money to put in one's own pockets. Seen from this perspective, the CNRP's seven points were chiefly made up of promises of money to be pocketed individually, and this was what had convinced an increasingly greedy electorate (senior CPP leaders, author's personal communication, November-December 2013).

These respective analyses formed the basis of the two parties' post-election strategies. The CNRP continued to place a strong focus on raising minimum 
salaries, framing this as a right. For example, at a demonstration on the International Human Rights Day in December 2013, Sam Rainsy (2013) claimed that four basic human rights were still lacking in Cambodia: the right to life; the right to decent and dignified living conditions; the right to freedom; and the right to elect political leaders. Salaries, he stated, were integral to both the second and third rights, as a fair salary would guarantee that workers could live in a decent manner and enjoy freedom rights.

The CPP, on the other hand, increased the scale of gift-giving, rather than changing the manner of provision. A comparison of the number of times gift-giving and other ceremonies were mentioned in the Hun Sen cabinet newsletter Cambodia New Vision and the CPP-friendly Deum Ampil News, Cambodia Express News and Kampuchea Thmey daily online newspapers between October and November 2013, and the same period in 2012, showed that this had increased rather than decreased in the post-election period (Steve Heder, author's personal communication, 10 December, 2013). The recipe for recovery was more and better of the same, rather than a changed strategy. This was clearly because the party reasoned that voters' main priority was to increase the amount of money they could pocket, with little regard for the terms. At the same time, the CPP also made some concessions to address the question of salaries pushed for by the CNRP. Little more than a week following the elections, the CPP announced an increase in basic salaries for civil servants with at least $40 \%$ - to eighty us dollar (though still a far shot from the CN RP's promised 250 us dollar) to take effect from the first of September (Vong and Worrell 2013). In November, an inter-ministerial committee was formed, tasked with overhauling the salary system of state employees, including civil servants, military, national police, retirees and professional disabled people (Hul 2013).

How are we to understand the current changes in the political landscape? Do they signal a changing political conscience, whereby voters demand better living conditions as a matter of right rather than privileges? Or does the electorate primarily seek to improve its economic status, no matter on what terms?

\section{Everyday Politics of Elections and Emerging Forms of Citizenship}

A useful vantage point from which to approach these questions is offered by everyday interactions between citizens and public authority. The study of everyday politics has typically omitted all that is related to elections, finding 
these far too exceptional. Maintaining that everyday politics cannot possibly be distinguished from the formal politics of electoral contests since discussions about elections, candidates, policies and campaigns are a regular feature of day-to-day life, Andrew Walker (2008) has suggested that we study the 'everyday politics of elections'. This draws attention to how electoral contests are embedded in local social relationships and values that relate to day-to-day politics and spill over into the electoral arena. Walker uses ethnographic fieldwork to trace the popular values that shape judgments about legitimate and illegitimate political power in electoral contexts, and determine why certain candidates are preferred above others. Framing these as a 'rural constitution', he reconceptualizes popular political behaviour that is otherwise dismissed as simply conforming to a patron - client model.

Transforming popular values and practices, which guide interactions with the public authorities, arguably provide a privileged prism with which to conceptualize the vast change in the Cambodian political landscape after the 2013 elections. Several factors which can plausibly be assumed to have contributed to the surge in electoral support for the opposition are bound up with, and feed directly into, a change in everyday relations. Civil servants, military personnel and policemen were attracted by the CNRP's promise of a salary rise - a pledge which promised to transform the very terms of engagement with the population by combatting low-level corruption. Promises of salary rises also attracted the traditional support base of the opposition, particularly garment workers who had migrated to the capital and the rising numbers of overseas workers. Many victims of land-grabbing and evictions, often occurring with unclear legal status and carried out by actors with murky relations to the government, are also believed to have joined the CNRP. ${ }^{12}$ Meanwhile, an increase in social media, Facebook in particular, has created an alternative information outlet, bypassing official channels dominated by the CPP, where public authority can easily be scrutinized and criticized. ${ }^{13} \mathrm{~A}$ larger desire for political change

12 In 2012, the Cambodian League for the Defence and Promotion of Human Rights (LICADHO) estimated around 400,00o Cambodians, out of a total population of 14,3 million to have been affected by land grabs and land disputes since 2003. An ongoing land titling scheme initiated by Prime Minister Hun Sen in 2012 has done little to ease tensions. This scheme can be aptly described as having a twilight character, as it is carried out by youth volunteers funded by the Hun Sen family and the CPP.

13 In March 2013, Cambodia's Ministry of Post and Telecommunications reported 2.7 million internet users, amounting to an internet penetration rate of $18 \%$. The estimated number of Cambodian Facebook accounts in July 2013 was 740,00o, a rapidly growing number. See Suy (2013) and Meyn (2013). 
surfaced, which appeared to be directly centred around relations between the population and political leadership. International influences may have also played their role, with examples ranging from the Arab Spring (routinely used as an example by the CNRP) and the sharp drop in electoral support for the dominant parties in nearby Malaysia and Singapore - two countries which have both served as models for state - society relations for CPP-led governments. ${ }^{14}$

How these changing interactions relate to the legitimacy of competing political party models of provision is a vexed question. At the 2013 meeting of a political discussion group, I chaired a debate on whether the politics of gift-giving has lost its hold as a model of popular political behaviour in Cambodia (Politikoffee meeting, Phnom Penh, 30 November, 2013). The participants were a group of young Cambodians in their twenties, all university students or university graduates employed by NGOS, universities or government bodies. Drawing on their personal experiences from their home provinces, they represented starkly different views that can be broken into three main lines.

The first view held that gift-giving practices are no longer sufficient to gain political allegiance. In view of a blatant discrepancy in living conditions, giftgiving angered, rather than appeased, the electorate. In support of this argument, participants pointed to how the CPP provided gifts to a majority of the population ahead of the elections, yet the vote was almost equal between the CPP and the CNRP. Thus, the election results demonstrated that gift-giving practices have ceased to be effective.

A second line held that gift-giving practices do remain effective for shoring up political support. In the case of the CPP, it was argued, the loss of electoral support reflected that local-level CPP authorities had failed to provide the gifts adequately, and therefore their promises had not been delivered upon. Villagers who had not received any gifts, unlike their peers, chose to punish the CPP at the polls.

A third line similarly held that gift-giving practices remain effective for mobilizing political support in rural Cambodia, and emphasized how this was coupled with security considerations, as not voting for the CPP was perceived as potentially destabilizing. Moreover, a vote for the CNRP could result in the withholding of access to state services. In one participant's words, voters could choose between receiving gifts and threats, or just threats.

14 Hun Sen (interview by the author, 29 August 2011) has cited the policies of Dr Mahathir (prime minister of Malaysia 1981-2003) as an important influence for his rural development and poverty reduction policies. On the rule of law in Singapore as a model for Cambodia under the CPP, see McCarthy and Un (2013). 
Ethnographic evidence demonstrates that these three dynamics are at play at the same time, often interlacing in surprising ways. ${ }^{15}$ Some villagers who joined the CNRP were angered by the CPP-gifts (which typically amounted to a few thousand riels and a sarong), given how their needs were much more dire (pro-CNRP demonstrators, interviews by author and research assistants, Phnom Penh, 15-31 December 2013). Meanwhile, there was also disappointment with the CPP on the part of long-time party supporters, who had lost access to resources they previously enjoyed, and felt unfairly treated by the party. ${ }^{16}$ Such disgruntled voters included victims of land-grabbing in the Phnom Penh communities of Borey Keila and Boeung Kak. When protesting their ordeal, these community members typically carried photos of the top troika of the CPP - Hun Sen, Heng Samrin, and Chea Sim - in a plea for their personal intervention. ${ }^{17}$ Having little to do with the CNRP agenda, this rather reflected the discontent of former CPP supporters who had failed to maintain their access to resources.

Though lacking the rural network of the CPP, the CNRP nevertheless made use of their support base of garment and other workers in Phnom Penh to influence rural constituencies. Workers put financial pressure on relatives in their home provinces, threatening to withhold the remittances that they sent, to ensure that their family members would vote for the CNRP (pro-CNRP demonstrators, interviews by author and research assistants, Phnom Penh, 15-31 December 2013). Their accounts demonstrated a real conflation of motivations. While the workers were primarily motivated by concerns about their livelihoods, these concerns had been put into a coherent political framework of rights-claiming by the political opposition over a longer period of time. Relatives in the home provinces were given a financial incentive to vote for the CNRP, but probably not without political discussion. In these accounts, weariness with gift-giving as a political practice could not be easily separated from displeasure with what was perceived as the inadequate scale of resource provision.

The police and the military are two main support bases where the CPP appears to have lost support. For example, according to the CPP's own estimates, in one district almost half of the soldiers who were expected to vote for

15 This information was collected by the author and eight research assistants in Phnom Penh between November 2013-January 2014, and is made up by discursive interviews with sixty-four CNRP supporters.

16 CPP leaders estimated a narrow majority of CNRP voters to be CPP members. Author's personal communication with senior CPP leaders, November 2013.

17 A practice extolled by Hun Sen; see Kong (2012). 
the party instead voted for the CNRP (CPP working group member, interview by the author, 1 August 2013). Two Radio Free Asia interviews broadcast in the aftermath of elections typify the sources of this discontent. ${ }^{18}$ A policeman, asked why he had come to support the CNRP, declared his dissatisfaction with not making enough to make ends meet, although he had been a policeman and CPP member for decades. The cutting of a portion of his salary for the benefit of the Cambodian Red Cross provided the last straw. In a second interview, a soldier stationed at the Preah Vihear temple on the Thai-Cambodian border similarly pointed to inadequate income. Though he risked his life at the border, his salary remained small, whilst his superiors enjoyed flamboyant lifestyles in the safety of Phnom Penh. In this context, the superiors' occasional visits to the border to hand out small donations of approximately 10,000 riel (2.5 Us dollar) at a time angered, rather than appeased, the soldier. Moreover, whilst this soldier had worked for the armed forces for more than two decades, he had not been able to rise beyond the rank of captain. Famous comedians, however, were enlisted from outside and immediately promoted to high ranks (cf. Wallace 2011). These two accounts show how the quest to secure the right to better income and access to resources, and the rejection of gift-giving practices as inadequate, were entangled. Meanwhile, the CPP's strategy of enlisting popular entertainers to the armed forces in order to boost their popularity had the adverse effect of enraging those left behind.

This development gave the opposition the impression that the CPP's hold on power, backed up by their hitherto unwavering grip over the national security apparatus, could be seriously challenged. The conflation between the CPP and the state means that security institutions have largely functioned as an extension of the party. ${ }^{19}$ In the aftermath of the elections, the CNRP repeatedly urged police and military to take the side of demonstrators and demand a change of government (see, for example, Neou and Peter 2013). The CNRP also encouraged such expectations in order to assure supporters and demonstrators of their safety. For example, images of CNRP security staff unprecedentedly sitting down together with police at Freedom Park were widely circulated in social media. However, starting from early January 2014, such hopes were dashed as garment worker demonstrations, supported by the CNRP, were countered by deadly police violence, which was then followed by a general crackdown on oppositional activities and a ban on assembly.

\footnotetext{
18 Radio Free Asia news broadcasts, August 2013.

19 For example, in the run-up to the 2013 elections, the armed forces and police openly campaigned for the CPP. See Human Rights Watch (2013).
} 
This crackdown, still ongoing at the time of writing in February 2014, has thrown the twilight character of security into sharp relief, as well as the political ends that it serves. In the repression of dissent that unfolded over January 2014, municipal and district security guards were called in alongside regular security forces to enforce the ban on assembly by violently clamping down on demonstrations. This practice came under fierce criticism by the media and representatives of civil society, who maintained that the security guards were not legally mandated to assume this task. Critics believed that the rationale of the practice was to allow the government to maintain deniability, keeping itself at arm's length from the violence in order to escape direct blame for unpopular acts (see, for example, Meyn and Aun 2014). In response, government spokesman Phay Siphan ambiguously clarified that such individuals were hired by Phnom Penh City Hall from private security firms, and that the authorities referred to them as 'police agents' (Pye and Khouth 2014).

Known as sândap thnoap, these security guards in fact form a branch of the municipal and district police, and are responsible for the maintenance of public order. They have the authority to carry weapons if they are authorised by the judicial police, and are legally bestowed coercive power when public order is disturbed. While newspapers and NGOs deplored how these forces pretended to have legal authority to use force when in fact they lacked it in reality, the dynamic was the very opposite - these forces' use of violence was legally sanctioned, yet portrayed as legally ambiguous. Rather than using their official uniforms, the security guards showed up to demonstrations wearing red scarves and motorbike helmets - a practice arguably intended to make them appear anonymous and unaccountable.

In a converse manner, this very likely served the very same purpose as that singled out by the critics: by refraining from clarifying the legal mandate of these officers, the government could keep its distance from ongoing violence. At the height of political tension in December 2013, shortly before violence erupted, Prime Minister Hun Sen warned people to 'beware of the third hand', provoking rife speculation over who this might refer to. Some observers considered it a threat to employ agent provocateurs to stir up violence, which would then justify a harsh government response. As the crackdown started, the scores of young male security guards lacking official designation were quickly equated with such a third hand. ${ }^{20}$ The very discourse of the 'third hand'

20 Given the purposely secretive nature of these forces, it cannot be excluded that outside individuals lacking legal authority are also enlisted. Yet, the core of these forces appears to be formed by the sândap thnoap. The main point of the third hand policy is precisely this: that the public may not know who the forces are made up of. 
underscores the political expediency of maintaining confusion as to the legal mandate of public authority, and offers an interesting example of the purposeful 'twilighting' of security by the government.

A range of institutions with fuzzy mandates, in fact, exercise public authority when providing security. For example, our lunch host (introduced at the opening of this chapter), who provides security at Phnom Penh's O'Russey market, also holds the title of sândap thnoap. More commonly, however, he simply refers to himself as a security guard (sântesokh or yeam). Sambath is employed by O'Russey market, which is in turn charged by Phnom Penh City Hall with the hiring of security personnel. A majority of security staff at O'Russey market are employed under this form of contract, which demonstrates the twilight character of the provision of market security. The market is semi-autonomous, yet exercises public authority in assuming state qualities of governance. Though a few of Sambath's colleagues are police cadres directly employed by the municipality, this form of contract typically requires one to have worked at the market for more than a decade, and excludes those who like Sambath - have family or other ties to opposition parties.

O'Russey market vividly illustrates the politicization of twilight institutions in Cambodia, as well as the possibilities these offer for everyday values and practices to be renegotiated between citizens and public authorities. Among the largest markets in Phnom Penh, O'Russey houses several floors and is frequented by residents from across the city. Market security is organized in a pyramidal structure - it is headed by a market committee with five to six members, presided over by a director and a deputy director. The market committee sits on top of four divisions (mondol) with 20-22 staff members each, each of which is in turn divided into three teams (krum). During the time that a power-sharing formula was in place in government between CPP and FUNCINPEC (from 1993 to 2008), a quota system also operated for this structure - though not strictly state - with a certain number of the staff belonging to the CPP and FUNCINPEC respectively. Upon the disintegration of FUNCINPEC, following the 2006 ouster of Ranariddh as party president, all security staff were required to submit a request to join the CPP in order to retain their employment. The president of the market, Kieng Leak, is an in-law of Chea Sophara, former CPP mayor of Phnom Penh.

The twilight character of market security has helped the CPP to integrate sections of it as an important, covert part of the party security apparatus. Forming a special unit of sorts, around forty security guards (sândap thnoap) from O'Russey are regularly employed for counter-demonstrations in and around Phnom Penh - invariably appearing in civilian clothes. Such events include garment worker demonstrations, protests over land evictions, and, 
allegedly, the force's involvement in protests against CNRP leader Kem Sokha ahead of the July 2013 elections, as well as a September 2013 attack against antieviction activists, with close ties to the CNRP, at Phnom Penh's Wat Phnom (O'Russey market security guards, interviews by the author, Phnom Penh, December 2013). This force was also employed to enforce the ban on assembly at Phnom Penh's Freedom Park in January 2014, when demonstrators were forcefully prohibited from entering the area (O'Russey market security guards, interviews by the author, Phnom Penh, January 2014). Though these security guards normally work side by side with other market security guards, their tasks go far beyond those of their peers.

The economic arrangement at the market has sown discontent among many of the other security guards. Guards have dual sources of income - firstly, they raise a monthly salary of 90,00o riel (22.50 us dollar) and, in addition, vendors pay a monthly fee of 20,000 riel (five us dollar) per stand (luy yeam), of which the security guard keeps about $70 \%$, passing on the remaining $30 \%$ to the market committee. Whilst the exact sum is negotiable, a lower-level security staff typically keeps about $300,000-350,000$ riel $\left(75^{-87.50}\right.$ us dollar) per month. Senior guards earn more, averaging a total income of 200 us dollar per month. Out of the luy yeam that is passed to the market committee, donations are given to support, in particular, pro-CPP newspapers. The market leaders also detract 3000 riel ( 0.75 us dollar) per month from the salary of each security guard as a donation to the Cambodian Red Cross. Amounting to but a small amount of money, the main purpose of this practice is arguably to increase the membership number of the CRC, as a donation automatically bestows membership. Security guards are also requested to donate 3000 riels each to the CPP annual 7 January celebration, which they are brought to celebrate at Phnom Penh's Olympic Stadium. Security guards interviewed expressed their annoyance at these practices, citing them as reasons for covertly supporting the CNRP.

The twilight character of market security also facilitates the renegotiation of relations between security and vendors, providing a potential challenge to the status quo. The government has long controlled the market place, keeping a close eye upon known opposition supporters among vendors. At O'Russey, security guards are tasked with monitoring and managing vendors' political inclinations and are required to keep statistics of the vendors' political allegiance. They are expected to circulate and listen to the vendors' conversations and take note of what radio channels they listen to. This information is then used to identify supporters of the CPP and of the CNRP - lists of which are passed on to the market committee, which are said to be kept for internal use 
at the market. ${ }^{21}$ In the run-up to and aftermath of the July 2013 elections, these practices began to crack. Though all security guards at O'Russey outwardly support the CPP, this says little about what proportion of support is truly heartfelt, and the guards' easy switch to private roles makes it easier for them to engage in earnest discussion with vendors. The security guards estimated around only $20-30 \%$ of the guards to be loyal to the CPP (O'Russey market security guards, interviews by the author, Phnom Penh, January 2014). By contrast, market vendors appreciated approximately 90\% of vendors to support the CNRP (O'Russey market vendors, interviews by the author, Phnom Penh, December 2013).

The security guards and vendors interviewed described their relations before the elections as generally mutually suspicious, with little open discussion. Politics was a taboo subject and thus rarely ventured upon. After the elections, however, interactions between vendors and security guards changed dramatically. The surge in electoral support for the opposition opened up public discourse and emboldened voices of dissent. According to several security guards, vendors now dared to express their political views in discussions, and even openly listened to the often government-critical Radio Free Asia at their market stands. In the plain words of one security guard, 'vendors now dare to state their opinions freely'. Though security guards generally remain more cautious than vendors, both groups reported that it had become more frequent for lower echelon guards and vendors to communicate openly with each other, converging on their criticism of the economic arrangements at the market. Such interactions necessarily took place beyond the hearing reach of higherlevel market authorities, and one guard confided, 'Whereas before I never spoke to vendors about politics, we now frequently discuss current events, but we have to speak in secret' (O'Russey security guard, interviews by the author, Phnom Penh, December 2013).

Changing interactions like these are by no means unidirectional, nor are they universal and, in light of the uncertainty surrounding future political developments, could just as easily and swiftly be reversed. At Phnom Penh's Central Market, vendors reported being prohibited by security guards from exiting the market to witness Sam Rainsy's return, and video cameras were placed around the market to identify those who left to welcome him nonetheless (Phak and McMorran 2013).

21 Such practices have been reported from across the capital's markets. For example, vendors at Phnom Penh's Central Market stated that those among them known to be opposition supporters faced constant harassment. See Phak and McMorran 2013. 
Changing interactions between citizens and public authority can be studied in terms of these ongoing negotiations at the market that produce divergent outcomes. These range from security guards preventing vendors from attending the opposition leader's return rally, to guards furtively making friendship with vendors and then obtaining the video of said rally from them, to the covert employment of yet another group of guards to break up post-election demonstrations.

\section{Conclusion}

The securing of benefits, welfare and access to state resources is central for emerging conceptions of citizenship and democracy in Cambodia. Previous scholarly works, recognizing the centrality of provision for relations between populations and public authority in many national contexts in the Global South, has typically treated citizenship and clientship as necessary opposites either seeking to positively re-evaluate the pursuit of exceptional entitlements in a gift-giving economy (Chatterjee 2004, 2011; Walker 2008, 2012), or finding clientship to be rejected outright by populations aspiring for full citizenship rights (for example, Hughes (2006) charges that contemporary gift-giving practices lack any kind of cultural legitimacy in Cambodia). However, ongoing change in Cambodia challenges such a clear-cut distinction. Treating citizenship and clientship as mutually exclusive opposites fails to address the vast landscape of movements between these two conditions - where crucial things can happen. The popular perceptions and practices of accessing resources and welfare by right, and having this access mediated by personal relationships, can overlap substantially at times so that citizenship and clientship are best understood as blurred and potentially overlaying notions (cf. Robins et al., 2008). These different perceptions can also collapse and transform into each other. An initial push for improved living conditions has, for some, turned into a rejection of clientship and the yearning to secure rights.

Twilight institutions run like a red thread through these negotiations, exercising de facto public authority in key areas, ranging from the provision of developmental assistance to emergency relief and security. Two characteristics stand out in the Cambodian context: Firstly, it is through these institutions that the very quality and meaning of Cambodian democratic citizenship is being negotiated. Secondly, instances of what appears to be the purposeful attempt to keep the legal mandate of public authority ambiguous alert us to the political expediency inherent to twilight ambiguity.

A focus on these institutions allows us to discern changing dynamics in the relations between Cambodian citizens and public authorities that typically 
remain out of the spotlight. Interactions between ordinary people and institutions such as the Cambodian Red Cross, or everyday negotiations between market vendors and security staff who straddle the public and private divide, betray changing political perceptions and practices that are at the very centre of current goings-on. Facing economic hardships, some voters were infuriated by having to contribute to the funding of the $\mathrm{CRC}$ - one important channel of provision. Likewise, market vendors complained about how the money they had provided for market security was passed on to pro-CPP causes. In the words of Lund (2006:682), 'While the twilight has an opaque character, ... this is when and where politics 'happens'. If they do not amount to the proverbial double-edged sword, these twilight aspects certainly have the potential for generating divergent outcomes. Most sinisterly, the twilight nature of security was employed to facilitate the crackdown on post-election dissent. At the same time, the twilight character of these institutions also allowed ordinary people to transform their relations to public authority. Moving in and out of the public and private spheres, market security guards were more easily approached and interacted on more sincere terms with ordinary people. This change was potentially subversive as it compromised the guards' role of monitoring vendors' political allegiance. Emboldened by the closeness this afforded, one vendor would even give a DVD of Sam Rainsy's return to Phnom Penh to our host for our surprised lunch company to watch.

\section{References}

Chandler, D. (1991). The tragedy of Cambodian history: Politics, war and revolution since 1945. New Haven, CT; London: Yale University Press.

Chatterjee, P. (2004). The politics of the governed: Reflections on popular politics in most of the world. New York: Columbia University Press.

Chatterjee, P. (2011). Lineages of political society: Studies in postcolonial democracy. New York: Columbia University Press.

Connors, M. (2003). Democracy and national identity in Thailand. London: Routledge Curzon.

Corfield, J. (1994). Khmers stand up!: A history of the Cambodian government 1970-1975. Clayton, VIC: Centre of Southeast Asia, Monash University.

Frings, V. (1995). The Cambodian People's Party and Sihanouk.Journal of Contemporary Asia, 25(3), 356-365.

Heder, S. (1995). Cambodia's democratic transition to neoauthoritarianism. Current History, 94(596), 425-429.

Hughes, C. (2001). Transforming oppositions in Cambodia. Global Society, 15(3), $295^{-318 .}$ 
Hughes, C. (2002). Parties, protest and pluralism in Cambodia. Democratization, 9(3), $165^{-186 .}$

Hughes, C. (2006). The politics of gifts: Generosity and menace in contemporary Cambodia. Journal of Southeast Asian Studies, 3r(3), 469-489.

Hughes, C. (2009). Reconstructing legitimate political authority through elections? In J. Öjendal \& M. Lilja (Eds.), Beyond democracy in Cambodia: Political reconstruction in a post-conflict society (pp. 31-69). Copenhagen: NIAS Press.

Hul, R. (2013, November 28). Government prepares civil service pay overhaul. The Cambodia Daily. Retrieved from http://www.cambodiadaily.com.

Human Rights Watch. (2013, July 22). Cambodia: Army, police campaign for ruling party. Retrieved from http://www.hrw.org.

Hun, S. (1991). 13 tosâvot nei domnaoer Kampuchea [13 decades of Cambodia's evolution]. Phnom Penh: Pracheachon.

Hun, S. (2005). Selected comments at the graduation and presentation of diploma to the graduates from the Asia-Europe Institute. Cambodia New Vision, go.

Hun, S. (2007). Keynote address at the opening ceremony of the Samdech Hun Sen's tree nursery station at Takeo's Phnom Tamao. Cambodia New Vision, 117.

Kong, S. (2012, March 16). Hun Sen extols use of his photograph by protestors. VOA Khmer. Retrieved from http://www.voacambodia.com.

Lund, C. (2006). Twilight institutions: Public authority and local politics in Africa. Development and Change, 37(4), 685-705.

McCarthy, S., \& Un, K. (2013). Rule of law without democratization: Cambodia and Singapore in comparative perspective. Unpublished draft.

Men, N.S., \& Dickens, T. (2005). United for humanity. Phnom Penh: Cambodian Red Cross, International Committee of the Red Cross and the Federation.

Meyn, C. (2013, November 11). Virtual democracy. Southeast Asia Globe. Retrieved from http://www.sea-globe.com.

Meyn, C., \& Aun, P. (2014, January 7). Government finds deniability in district security force. The Cambodia Daily. Retrieved from http://www.cambodiadaily.com.

Neou, V., \& Peter, Z. (2013, August 13). Sam Rainsy rejects accusations of inciting military coup. The Cambodia Daily. Retrieved from http://www.cambodiadaily.com.

Norodom, R. (1998). Droit public cambodgien. [Perpignan]: CERJEMAF/Presses Universitaires de Perpignan.

Öjendal, J., \& Lilja, M. (2009). The never-ending hunt for political legitimacy in a post-conflict context. In J. Öjendal \& M. Lilja (Eds.), Beyond democracy in Cambodia: Political reconstruction in a post-conflict society (pp. 297-312). Copenhagen: NIAS Press.

Pak, K., Horng, V., Eng, N., Ann, S., Kim, S., Knowles, J., \& Craig, D. (2007). Accountability and Neo-Patrimonialism in Cambodia: A Critical Literature Review. Phnom Penh: Cambodia Development Resource Institute. 
Phak, S., \& McMorran, M. (2013, July 22). Vendors made to toe party line. Phnom Penh Post. Retrieved from http://www.phnompenhpost.com.

Pye, D., \& Khouth, S. (2014, January 22). Ban foes undeterred. Phnom Penh Post. Retrieved from http://www.phnompenhpost.com.

Robins, S., Cornwall, A., \& von Lieres, B. (2008). Rethinking 'citizenship' in the postcolony. Third World Quarterly, 29(6), 1069-1086.

Sam, R. (2008). Des racines dans la pierre: Mon combat pour la renaissance du Cambodge. Paris: Calmann-Lévy.

Sam, R. (2013, December 10). International Human Rights day speech, presented in Phnom Penh.

Slocomb, M. (2006). The nature and role of ideology in the modern Cambodian state. Journal of Southeast Asian Studies, 37(3), 375-395.

Suy, H. (2013, March 25). Cheap data, better tech putting more Cambodians online. Voice of America. Retrieved from http://www.voanews.com.

Thompson, A. (2004). The suffering of kings: Substitute bodies, healing, and justice in Cambodia. In J. Marston \& E. Guthrie (Eds.), History, Buddhism, and new religious movements in Cambodia (pp. 91-112). Honolulu, HI: University of Hawaii Press.

Un, K. (2005). Patronage politics and hybrid democracy: Political change in Cambodia, 1993-2003. Asian Perspective, 29(2), 203-230.

Vong, S., \& Worrell, S. (2013, August 8). Civil servants to see raise. Phnom Penh Post. Retrieved from http://www.phnompenhpost.com.

Walker, Andrew. (2008). The rural constitution and the everyday politics of elections in northern Thailand. Journal of Contemporary Asia, 38(1), 84-105.

Walker, Andrew. (2012). Thailand's political peasants: Power in the modern rural economy. Madison, Wisconsin: University of Wisconsin Press.

Wallace, J. (2011, June 15). In Cambodia, comedians double as government propagandists. The Atlantic. Retrieved from http://www.theatlantic.com. 


\title{
Sosialisasi, Street Vendors and Citizenship in Yogyakarta
}

\author{
Sheri Lynn Gibbings
}

In 2006 and 2007, Pethikbumi (Pedagang Klithikan Mangkubumi), a group of street traders ${ }^{1}$ slated to be relocated to a newly renovated marketplace in Yogyakarta City, Indonesia, argued in government meetings and in the newspaper that the relocation plan was not clear (kurang jelas). The Kedaulatan Rakyat newspaper reported that 'the leader of Pethikbumi, Akbar, said the concept developed by the municipal government regarding the relocation was not transparent (tidak transparan), especially with money.... "I also have asked for a detailed relocation concept but I haven't been given it,' said Akbar." In the months leading up to the relocation deadline of November 2007, Pethikbumi publically critiqued the municipal government's lack of proper sosialisasi (socialization) regarding its plans to relocate hundreds of traders to a marketplace through letters to the government, newspaper articles and public and private meetings.

Proposed by then-mayor of Yogyakarta City, Herry Zudianto, the klithikan (second-hand trader) relocation would move street vendors from three locations in the city to a renovated former animal marketplace, Kuncen. The traders would gain clear legal status and be empowered to develop their businesses. $^{3}$ The new marketplace was also pegged to become a tourist attraction because it would bring together in one location a variety of traders selling second-hand and antique merchandise (Pethikbumi meeting, personal communication, January 16,2006 ). With this plan, the municipal government of Yogyakarta intended to follow the example of the mayor of Solo (now governor of Jakarta), Joko Widodo, who had 'successfully' relocated klithikan traders in

1 Street traders are referred to as pedagang kaki lima ( $\mathrm{PKL})$ in Bahasa Indonesia. In the paper I use the terms street traders and street vendors interchangeably.

2 'Konsep Pasar Klithikan Dinilai Kurang Jelas: Tolak Relokasi, Pethikbumi Datangi Dewan' Kedaulatan Rakyat, March 16, 2007.

3 These statements are still used by the municipal government in the production of information about Kuncen marketplace. A book profiling the different marketplaces in Yogyakarta says that the relocation was a successful attempt by the government to better the lives of the people (traders), despite the conflict between the pro and contra traders (Dinas Pasar Yogyakarta 2013:31). 
2006 without violence (Sinombor 208). ${ }^{4}$ As in Solo, the klithikan relocation in Yogyakarta was considered a generous gesture by the municipal government because the traders were offered an indoor location for free, financial support as well as training during the transition period.

The municipal government of Yogyakarta publicly promoted the idea that they were 'dialoging' (consulting) with Pethikbumi traders in 2007. However, the details of the project and plan had already been under discussion for years, mostly without the traders' involvement. ${ }^{5}$ In 2004 and 2005, the government conducted a series of confidential and undisclosed surveys, analysing the impact on the surrounding community, traders and land. The Impact Control Office (Kantor Pengendalian Dampak) produced the Kuncen Market Development Plan (Pemerintah Kota Yogyakarta) in 2004 and consultants employed by the government produced two of the other reports written in 2005 (see CV. AKA and PT. CIPT Nindita Buana). These reports provided support for the relocation and outlined the potential effects this would have on various communities such as the surrounding neighbourhoods, traders and parking agents.

Almost all of these reports recognized that there might be resistance to the relocation. The solution to this problem was 'socialization' (sosialisasi), which meant talking to the different groups about the programme, including the street vendors and surrounding communities ('Rencana Pembangunan Pasar Kuncen' 2004). In 2005, the government started discussions with several of the Pethikbumi traders, and took them on a comparative study trip to Bandung, a city in West Java ('Polemik Klithikan' 2006). Yet the majority of the traders remained in the dark about the relocation plans and in October 2006 a number of traders accused Pethikbumi's leaders of taking bribes to accept the relocation ('Polemik Klithikan,' 2006). At this point, a new group of traders took control of Pethikbumi and demanded that they see a written relocation plan (konsep relokasi).

This chapter discusses the changing nature of citizenship in Indonesia since the political transition in Indonesia (Reformasi), through the case study of the government relocation of street vendors to Kuncen Marketplace. I focus on the term sosialisasi because surprisingly little attention has been given to this term and its practices in academic literature on Indonesia, yet it is commonly used to describe practices of consultation and communication across the

4 The newspaper article stated, 'For six months Jokowi and Hadi Rudyatmo invited the sellers to dialogue. If we want quick and easy, we could. With our authority, we could just turn up with a bulldozer, clear, and be finished'. (Sinombor 2008).

5 A leader from the Aseme Gede group did receive information about a possible relocation in 2004, but this information was not widely circulated ('Gugatan TUN' 2007). 
Indonesian archipelago. The fact that sosialisasi was used so frequently during the New Order as part of Suharto's Festival of Democracy (Pemberton 1994) also raises questions as to what extent the meanings and practices of sosialisasi are changing in the current era.

In the New Order intepretation sosialisasi is a process in which the government (or another top-down institution) teaches/persuades another group (generally a less powerful or more 'ignorant' group) to follow a prescribed viewpoint/set of behaviours. The current municipal government continues to view it this way. In the case of the relocation, civil servants perceived sosialisasi as a process through which the vendors are persuaded that the relocation is in their best interests. However, when Pethikbumi claimed the government did not sufficiently 'socialize' the vendors about the relocation, they were not using the term in the same sense. The vendors understand socialization to mean something different: the provision of transparent and detailed plans about the relocation, an open and meaningful consultation in order to reach a mutual agreement about a relocation plan that addresses the vendors' concerns.

I argue that in order to understand changes in citizenship in Indonesia we must chart and understand the words and practices through which claims are made. I show how the New Order term sosialisasi is taken up by street vendors, a largely illegal and marginal group, as a means to claim their rights. Especially since Reformasi, traders have gained support from civil society groups (NGOS, legal aid organizations, and student groups) that are helping them make claims for their rights. In order to understand citizenship we must situate its practices in local discourses, networks and politics (cf. Humphrey 2004:433). I illustrate how there are certain habits and discourses of sociality, namely sosialisasi, that are being carried forward and challenged in post-Suharto Indonesia.

\section{Citizenship and Street Vendors: A Changing Landscape}

Anthropologists working on citizenship have noted that while by law people might have equal rights, in practice many inhabitants of a state cannot realize these rights (Chatterjee 2004; Holston 2008; Ong 1999). James Holston (2008:7), for instance, illustrates that Brazil is characterized by a form of 'differentiated citizenship' which is 'universally inclusive in membership and massively inegalitarian in distribution'. In India, Partha Chatterjee (2004:40) describes how many illegal and marginalized groups have pressured the government to provide them with assistance and entitlements through patron - client networks and their strategic use of the vote. He argues that these marginal citizens are excluded from civil society, the domain of 'proper' citizens, and are instead 
part of what he calls 'political society'. Akil Gupta (2012:99) similarly argues that citizenship has a different meaning in the postcolonial context because it is not always 'imbricated with the emergence of civil society'.

In the Indonesian case, the concept of rights almost always appears with the term responsibility or duty (hak dan kewajiban). During the New Order, the rights of individual citizens were seen as subservient to the interests of the collective. Under Suharto, the government often claimed that freedom of expression should be curtailed for the sake of maintaining national unity, political stability and economic development. In the post-Suharto period, discussion of rights as relating to collective responsibilities has continued. In the Jakarta Post an opinion piece states, 'Citizenship implies not only individual rights but responsibilities toward the group. The concept of the civil society means learning to consider the needs of the group and of fellow citizens. For every right there is a corresponding responsibility' ('Education' 1999). I often heard ideas like this during my fieldwork. The traders would argue that they had certain rights but that they also had many responsibilities to fulfil such as keeping the street clean, safe and orderly.

In addition to citizenship meaning different things to different people in Indonesia, numerous groups compete over the authority to oversee citizenship claims. In Indonesia, power is comprised of a patchwork of competing authorities involving a mixture of state and non-state actors (Barker and Van Klinken 2009). ${ }^{6}$ Gangs, vigilantes and private security commonly lay claim to the kinds of authority traditionally monopolized by the state (cf. Barker 1998, 2006, 2009; Hansen and Stepputat 2001). Christian Lund (2011:888) argues that different institutions compete to define and enforce rules, and in effect secure recognition as the actors who have the right to provide 'rights' to others. He concludes that we must not only examine the rights people have, but also the various institutions that guarantee and protect these.

In Indonesia there have been a number of different actorsinterested in controlling where and how street vendors operate. During the colonial period, street sellers (pedagang) often travelled door-to-door selling fruits, vegetables, and other goods and services. The colonial government was concerned with containing these traders, and as a result urban planners such as Thomas Karsten built marketplaces in cities across Java to do just that (Jessup 1985; Kusno 2005). Immediately after independence, street trading increased as vendors provided the native population with access to cheap merchandise and food (Jellinek 1991). Like its predecessors, however, this new Indonesian

6 I do not see the state as a singular entity; similar to Akil Gupta (2012:55) I view it as 'historically contingent, incomplete, and perhaps even tenuous.' 
government was concerned with creating cities that were 'modern'. As street vendors were considered part of what made the city and street appear 'unmodern', traders needed to be relocated and contained in a marketplace (Kusno 2005).

During the Suharto years (1965-1998), a patchwork of competing authorities sought to control the rights of street traders. After Suharto came to power, street vendors started to occupy sidewalks in more permanent ways; by the 1970 and 8os, many set up kiosks and began to 'own' a certain square meter of the sidewalk. Some traders managed to negotiate their rights to the street temporarily at least in exchange for supporting Suharto's political party, Golkar (Dody, personal communication, June 2007). ${ }^{7}$ Others managed to obtain rights to the street by informally paying fees to the military, gangsters, or Golkar's security group Pemuda Pancasila for protection. The traders did not have the formal right to sell on the street, but were able to do so because of the cultivation of informal relations that allowed them to circumvent state policies. In particular instances, the municipal authorities extended rights to traders on an exceptional basis, without jeopardizing the overall idea that vending did not belong on the street but in marketplaces (cf. Chatterjee 2004). The 1970s and 8 os were thus marked by an 'entire substructure of paralegal arrangements' created or at least recognized by governmental authorities. These paralegal arrangements were not necessarily viewed as legitimate by society, but were also not frowned upon as much as other activities such as corruption (cf. Aspinall and Van Klinken 2011).

In the 1970 s and 8os, the growing number of 'permanent' street traders and their increasing power to control the street made them an important topic of study for academics and policymakers in Indonesia (Hammado 1979; Ichsan 1982; Waworoentoe 1975). The majority of these reports concluded that government policy was inconsistent toward traders, and that traders were engaged in different types of illegal exchanges in order to secure their right to the street. There was also a growing fear that street vendors needed to be controlled, monitored and generally looked after because otherwise they could turn violent (Masalah Pedagang 1980). The mayors in cities across Indonesia, typically appointed military personnel, continued the practice of trying to relocate

7 In 1981, some street vendors in Yogyakarta formed an organization called PPJ-Y (Persatuan Pedagang Pinggir Jalan Yogyakarta, or Yogyakarta Roadside Traders Union). The main goals at the time were to promote devotion (pengabdian), solidarity (solidaritas) and nationalism (kerakyatan), all aligned with Pancasila, the state philosophy (Bangun 1994). Kosgoro, with strong Golkar affiliations, helped form Tri Dharma (Dody, personal communication, June 2007). 
traders to marketplaces in order to achieve Suharto's central goals of cleanliness (keberishan) and order (ketertiban).

After the fall of the New Order in 1998, the constellation of rights and responsibilities began to shift because of two simultaneous processes: decentralization and democratization (Aspinall 2013; Telle 2009). Democratization has enabled civil society to grow stronger (Ford 2009; Hadiwinata 2004). Yet criminal elements have succeeded in creating spaces for themselves (Ryter 2009; Aspinall and Weiss 2012). ${ }^{8}$ As a result, there are now even more actors competing for control over territories and resources. In addition, decentralization has caused local urban politics to have become more important, as power has shifted from the capital to local governments (Reerink 2009; Schulte Nordholt 2003).

Under growing pressure to increase revenues, collecting taxes from street vendors or new market traders has become an important income-generating strategy (Gibbings 2013; Reerink 2009). As municipalities try to capture the incomes of street traders by relocating them to marketplaces or through issuing temporary permits, NGOS and street vendor organizations are trying to convince authorities to treat traders and their organizations as legitimate members of civil society. As such, municipal governments are under increasing pressure from the public, civil society groups and international actors to use sosialisasi rather than forcibly evicting traders ('Satpol PP' 2012). Growing numbers of trader organizations have sought support from legal aid organizations, NGOs, and community organizations to help protect their interests, and to pressure municipal governments to listen to their concerns. When traders were being evicted in South Jakarta, several organizations (including the Indonesian Environmental Forum (Walhi), the Jakarta Legal Aid Institute and several university student bodies) supported the vendors by coming to the area to document any violence used against them ('Traders Brace' 2008).

Along with this pressure to 'dialogue' with traders through socialization, municipal governments have had more power to develop their own city-specific regulations on street vending (Reerink 2009). Almost every municipality has developed its own street vendor regulations (Dipa 2012). Many of these new regulations outline the rights of traders to the street, but also their responsibilities to maintain its cleanliness and security. In 2002, the mayor of Yogyakarta created a new regulation on street vending (Regulation No. 26 2002), which required every street vendor to obtain a permit from the government, pay a

8 Edward Aspinall and Meredith L. Weiss (2012:214) argue that in the 1990s, donor governments focused their attention toward supporting civil society groups. See their chapter for a history of civil society in Indonesia and Malaysia. 
tax, and hold an identity card (BPH K, personal communication, 12 December 2007)..$^{9}$ Despite this regulation, the majority of traders in Yogyakarta City did not acquire such a permit. Out of the 5,525 street vendors in fourteen districts of the city, only 837 had permits in 2005 (РT. СIPT Nindita Buana 2005). Most municipal government officials in Yogyakarta remain concerned that giving too many rights to traders will give street trading legitimacy. For example, officials would often complain that traders along Malioboro Street, a main street of the city, were too powerful and relocating them would be a nearly impossible task, particularly as there were concerns that other groups could reproduce these same power structures, resulting in the need to continuously evict vendors.

However, high-ranking individuals have also started to support the idea of empowering traders rather than evicting them. President Susilo Bambang Yudhoyono passed a Presidential Regulation (Perpres) about the organization and 'empowerment' of street vendors (Number 125 212) (Massa 2013). In March 2012, he argued that street vendors were beneficial to regions because 'poverty is reduced, also criminality in cities is reduced' (Liu 2012). Likewise, the coordinating minister for Economic Affairs, Hatta Rajasa, has become a member of the Honorary Board of the Indonesian Street Vendor Association (APKLI) and has declared his commitment to help protect (melindungi) street traders (Rajasa 2013). Joko Widodo, the president of Indonesia, has also become renowned for his 'humane' treatment of street vendors which is widely discussed in newspapers, and on Twitter and Facebook (Afifah 2012). However, like other leaders, Joko still believed that street vendors should be relocated to the marketplace, albeit in a compassionate and participatory manner (Dwi 2013). Generally traders see these changes as part of competitive electoral mobilization of the poor. Democratic political competition has enabled street vendors to look for alternative support in case a leader or party is not willing to support them. Authors such as Deasy Simandjuntak (2012) have described this as 'patronage democracy' and have noted that in this configuration clients do have gained more power vis-ntak (2012) have desc.

All these developments are changing the attitudes of street vendors. Since 1998, there has been a surge in the activities and visibility of civil society and their support of street traders especially during moments of eviction or

9 This legislation signified an attempt to shift authority from the street vendor organizations and the community back into the hands of the government. As a result, more than fifteen trader organizations across the city voiced their concern that they were being excluded as key actors, and that the trader organizations should provide recommendations regarding the permits (personal communication, 12 December 2007). 
relocation. The government is likewise ramping up its strategies to transfer and capture the incomes of traders to increase their revenues. Organized street vendor groups, with the help of legal aid organizations, NGOS and university student groups, demand that the concerns of the traders must be heard and addressed as citizens. Although traders are still in the business of striking deals with the police, criminal gangs, and political parties, I will illustrate that they are also simultaneously being incorporated into the realm of middle-class activism. I will first, however, describe the history of the term sosialisasi and how it is being used today.

\section{Sosialisasi: A Legacy of the New Order?}

During the New Order period, the state tightly controlled what information was available to its citizens. Tough restrictions and legislation to control the press were instituted (Hill 2006). During this era, instructions or orders were given primarily through community meetings with minimal recordkeeping, and this process was called sosialisasi. The term referred to the process of sharing information and gaining acceptance for new plans or regulations. After the fall of the New Order, the term continued to be used to suggest the sharing of information through face-to-face communication (Lazuardi, personal communication, 21 November 2013) $\cdot{ }^{10}$ One standard textbook used in middle schools claims, 'sosialisasi is a process of transferring values and norms through agents, actions, and patterns' (Maryati and Suryawati 2006:105). The agents of socialization in this context are described as the students' parents, peer group, school, and the media. Socialization can be 'repressive' (represif) or 'participatory' (partisipatoris). Repressive sosialisasi is when the law is used to penalize errors, and is described as one-way communication such as obedience to one's parents. Participatory sosialisasi is described as a pattern when children are symbolically rewarded or penalized for their behaviour. This participatory socialization process gives children more freedom, and emphasis is placed on verbal interaction and communication (Maryati and Suryawati 2006:109). ${ }^{11}$

The origins of sociology are closely connected to concerns over 'social control' and the idea that a society should regulate itself (Janowitz 1975:82). It is thus not surprising that the Indonesian government borrowed this sociological

\footnotetext{
10 I want to thank Elan Lazuardi for holding a discussion with colleagues at University of Gadjah Mada (UGM) in order to further clarify the meaning of the term sosialisasi for this paper (Lazuardi, personal communication, 21 November 2013).

The textbook is written in Bahasa Indonesia; the translations into English are my own.
} 
term for the realm of governance. The term sosialisasi was commonly used in the 199os to refer to training the poor and transforming their behaviour. ${ }^{12}$ Dozens of reports were produced regarding the 'sosialisasi of poor neighbourhoods' in South Sulawesi (Hamid et al., 1987), Yogyakarta (Salamun 1993) and Padang (Sumarsono 1987). Reports on the socialization of politics in schools and villages also appeared (Sumarno 1992; Yusrizal and Nurharmi 1997). In addition to reports, municipal governments carried out projects and programmes to 'control' and change the behaviours of groups such as street traders. The mayor of Yogyakarta from 1986 to 1991 described how the government used to socialize the street vendors. He said:

One time we socialized them. I let them know that there is a place for dirty water and a filter, and that the leftover food should enter the filter and the water would fall back into the bucket. Then the water could be disposed of later and would not carry garbage with it such as plastic.... I was very upset if I saw people throw away plastic. They were not aware so we clarified (jelaskan) it to them.

personal communication, 2007

During the New Order era, government practices of sosialisasi thus focused particularly on changing the behaviours of marginal groups and the poor, who were perceived to be ignorant or uneducated. For traders, this could include providing information about topics such as how to cook food hygienically or how to throw away garbage.

Despite this paternalistic connotation, the term sosialisasi surprisingly continues to be widely used since the transition to democracy and considered part of democratic practice. NGOs, university students who do kuliah kerja nyata (voluntary placements in rural areas), government officials and community members all regularly use the term (Lazuardi, personal communication, 21 November 2013). As a Human Rights Watch report (2002:32) notes, sosialisasi refers to a 'practice of disseminating information from the top through community leaders or mass communication'. A company called IndoAdvisors understands sosialisasi as necessary for any business project to be successful. Their website reads:

Developing good working relationships with local groups and agencies can be critical to the success of foreign companies' operations in Indonesia. This service, which is known here as 'Sosialisasi' (Socialization),

12 The term sosialisasi was commonly used alongside other terms such as penyuluhan (counselling). 
is in greater demand as more foreign companies become involved in industries related to natural resources. [...] A comprehensive 'sosialisasi' programme should make communities aware of the project's goals and ensure that stakeholders understand their respective roles and responsibilities. This is particularly essential to the success of any rural-based project, whether land or marine based.

SOSIALISASI, n.d.

In the business environment it thus refers to informing stakeholders about a project rather than necessarily obtaining their input.

Sosialisasi also appears in newspapers to refer to how government, legislation, or other institutions are communicating with communities about new programmes or issues such as healthcare, the effects of drugs, or electoral processes (Kementerian Perhubungan Republik Indonesia, n.d.). The term sosialisasi is changing its meaning, however. In 2008 the Freedom of Information Act was enacted which stipulates that public offices such as the police have a responsibility to regularly provide information to the public (Basorie 2011). ${ }^{13}$ Sosialisasi is now commonly used to suggest that the government or institutions have not communicated sufficiently about a new project or topic. A legislative member of commission B in Jakarta praised the government's plan to develop an electronic road pricing system but criticized them for not socializing the community (kurang disosialisasikan) (Kuwado 2013). Evident in all these discussions is that socialization is still sometimes about transforming behaviours but is also now about transparent communication being good in and of itself.

\section{A Street Vendor Relocation: Working with 'Civil Society'}

In the mid-199os, few traders could be found selling on Mangkubumi Street, a main street of Yogyakarta City lined with shops. But after the economic crisis of 1997, the number increased exponentially. With few formal sector jobs available, Mangkubumi Street had transformed by 2006 into a bustling night market with over three hundred vendors selling from seven to ten in the evening. ${ }^{14}$ Female vendors were a rarity on Mangkubumi Street, and the majority of

\footnotetext{
13 In 2010, a network of information advocacy groups found that nearly half of their requests were denied when they asked for information regarding local budgets, laws and bylaws, or legal cases (Basorie 2011).

14 It was estimated that the amount of money circulating on Mangkubumi Street was 47,995,00o rupiah (5,523 Canadian dollar) per day, with cell phone sellers contributing half at 22,80o,0oo rupiah.
} 
customers were men buying a wide array of goods such as shoes, shirts, jeans, and used cell phones. The large number of used cell phones and other secondhand goods sold there contributed to the night market's nickname, pasar maling, or the thieves' market. The shop owners on Mangkubumi Street, many of whom were of Chinese descent, found the night market troublesome. Although the majority of their shops were closed by the time the traders set up their wares in the evenings, many shop owners lived above their businesses and found it difficult to enter or leave their homes at night by motorbike or car. The shops that remained open in the evening found that their customers were hesitant to visit and instead went elsewhere. Despite their discontent with the traders, however, the shop owners were not particularly vocal in public forums because they were afraid of causing a conflict or being attacked..$^{15}$

In October 2006, after the relocation plan was announced more widely, the traders were divided. One group, Pethikbumi, decided to oppose the relocation because they believed that the government had not included them in the decision-making and planning process. In their opinion, the municipal government was discriminating against them by moving them, but not other traders in the city. They were also deeply sceptical about relocations of street vendors to marketplaces in general, because they often caused traders to go bankrupt despite government promises that they would benefit or 'progress'. The majority of Pethikbumi traders were making relatively comfortable incomes on the street because their customer bases were strong. Starting over again at a new marketplace in another part of the city was not an attractive proposition.

Other groups with names like Independent, Aseme Gede and the Southern Square, supported the relocation and were optimistic about the plan. They felt that through this relocation they would obtain a 'free' location (or asset) in a marketplace and that their social and legal status would improve. Many of the Independent traders had lower incomes than the traders of Pethikbumi, and therefore had less at stake. Most of the Independent traders were also less optimistic that movements to oppose the government would succeed.

Once the Pethikbumi traders decided to refuse the relocation, they looked to other groups to provide them with support. They approached the Human Rights Protection Agency (Badan Pelindung Hak Kemanusiaan, BPнк), which was a well-known legal aid organization in Yogyakarta City, and the Indonesian Youth Movement for Change (Pergerakan Pemuda Indonesia untuk Perubahan, P PIP),

15 Even six years after the relocation, some shop owners remained hesitant about voicing their opinions openly. This response must be understood in relation to the history of Chinese in Indonesia and recent events during the fall of Suharto (see Purdey 2006; Strassler 2004). 
a community organization that had a strong base of university students. BP HK connected the Pethikbumi traders with a network of NGOs, which also provided them with advocacy advice. The NGO Network is a pro-democracy alliance composed of different organizations from across Yogyakarta City. ${ }^{16}$

B P H K was formed in 1999 to provide legal counsel to the poor and marginalized. They support various groups such as factory workers, women survivors of violence and street vendors. Most street vendor leaders in the city knew Marini, the director of в Рнк, because she has been the public face of advocacy for groups of street vendors across the city. She was known for her ability to effectively communicate traders' concerns to the government in writing and through legal channels.

Reflecting on how the rights of street traders had changed in recent years, Marini explained, 'Before Reformasi, street vendors generally accepted [government projects]. I mean that whatever the government did, they considered themselves powerless. But since Reformasi, they believe they have the right to receive information.' Marini had taken up an important role in the postauthoritarian era, because she could help street vendors draft various requests to the municipal government and formulate arguments based on the law (вРнк, personal communication, 16 July 2013).

PPIP is a student-based organization that formed in 2001 in order to advocate for the democratic rights of the rakyat kecil (small people), a morally loaded term referring to people with little money or power. In March 2000, activists gathered in Yogyakarta to write a political manifesto for the organization and to discuss how theories of revolution could be put into practice. The PPIP manifesto states that it considers the position of its movement, organization and ideological struggle as a cultural strategy to respond to people's suffering and to deal with exploitation and oppression. (Manifesto Politik 2001). PPIP had a strong network of university students who were willing to show up for protests and were interested in writing press releases that challenged capitalism and the growing inequalities between the rich and the poor. Iskander, a university student studying international politics, had joined PPIP in 2004 and called himself a supporter (pendamping) of Pethikbumi. He explained why PPIP decided to help support Pethikbumi:

We at PPIP supported our friends of Pethikbumi at the time of the relocation because we wanted to develop a movement against the forces from

16 This chapter focuses primarily on вPнК and PPIP because the NGO Network played a secondary role. They helped to run meetings. 
the government our friends were facing.... They were invited to talk about moving, not to talk about whether or not moving was best. They invited them to talk, but told them to move. In my opinion, we helped Pethikbumi to refuse because they were only given one choice, that is to move.

ISKANDER, personal communication, 1 August 2013

Adang, the secretary of Pethikbumi, had been selling second-hand shoes on Mangkubumi Street since 2004. From his perspective, the traders themselves had the power to withstand relocation without the help of these outside groups. To be effective in the post-authoritarian era, they knew they had to use demonstrations and legal channels. Political channels were important, but as the traders and their supporters described in several meetings, they could not trust political parties even though they tried to build alliances with them. For instance, Toni from the NGO network said at a meeting, 'don't believe political parties because they are also bought. The difference between them giving information and them giving the right information is very significant' (ВРн К, personal communication, 25 October 2007). In another meeting, the traders and their supporters noted that despite what the leader of the legislature had said to them, they would have to cross-check the information because there was no guarantee that he would act as promised (NGO network, personal communication, September 2008).

Despite the belief that they could organize on their own, Adang explained that the traders wanted to make sure their advocacy was in done in a systematic fashion. As a result, they approached BPHK and PPIP for help. Adang said:

Our leaders were able, we knew the process. But for the technical side of things [we needed help]. If we wanted to subpoena, or report to a different organization within the region or things like that, we did not understand [the process] at the time.

ADANG, personal communication, 15 July 2013

Despite Adang's initial perception that they did not need outside support, the lawyers from в Рнк felt that groups like traders needed their support because otherwise the government would not answer their written requests. Pethikbumi had sent multiple letters to the municipal government without a response. In Marini's opinion the government was more likely to respond to BPH K's letters because they were an institution. Marini's husband, who also worked for вPнк, continued the conversation by suggesting that not answering the street vendor letters was perhaps a 'conflict strategy' of the government in order to force them to look for outside support. He said that perhaps the government 
wanted the traders to convert their grievances into a legal case because that was much safer than demonstrations and anarchy. Marini also noted that, it is not only street vendors but also factory organizations and community organizations. None of their letters have been answered.' She thought that perhaps the government was not familiar with these groups, but it was more likely that once these groups had the support of a legal aid organization, the government would know they were serious and respond (BРнК, personal communication, 16 July 2013).

In the post-authoritarian era, the avenues and means for negotiating evictions and relocations are changing. More groups of traders are partnering with NGOs, community organizations and legal aid organizations in order to fight relocations, and to advocate for their rights through these legal and formal channels. Although some of these traders groups have the capacity to advocate on their own, it is often through working with outside organizations that the street vendors gain recognition as members of civil society and obtain responses from the government (cf. Chatterjee 2004).

\section{Sosialisasi during a Relocation Project}

In the post-Suharto era, municipal governments have become more concerned with the socialization process because the possibility of encountering resistance is greater. This concern over possible resistance was recognized in early government reports (Pemerintah Kota Yogyakarta 2004:IV-2). During my fieldwork the strategy of socialization by government officials was often described as a process of 'getting close' to the various stakeholders. This meant spending time with traders and community members who would be affected by the process. In an interview, Mayor Herry Zudianto described his sosialisasi strategy as involving 'speaking in their language', meaning that he did not speak in the language of bureaucracy. He also approached the traders in places where they felt comfortable, like at a food stall rather than a stuffy office. He proudly told the story about how he had invited them to his private home in order to make them feel welcome, following the Javanese philosophy witing tresno jalaran soko kulino - the idea that love/respect grows through familiar or frequent communication (H. Zudianto, personal communication, June 2008).

The mayor did not meet with the traders often enough, however, and this was part of Pethikbumi's frustration with the socialization process. They argued that it was difficult to access him, and held a protest demanding that they meet with the mayor directly. Lower level government officials were largely responsible for socializing the project, but these officials were perceived 
as having little power to actually change the project (the traders had hoped that instead of being relocated they could be allowed to stay and instead be re-organized on Mangkubumi Street). ${ }^{17}$ A government official whom I interviewed described how important the socialization process was because there was often resistance. He said:

Actually by the year 2006 the project could have been implemented, but [it was delayed] because there were lots of interests at play from political leaders and people, and because the sellers did not agree. Finally, we needed to convince them that if they sell there [in Pasar Kuncen] they will sell more than in the old place. So we had to get close to them, to learn to speak their language so that they can understand us. And that is a long process.

Government Office of the Environment, personal communication,

6 February 2008

This process of 'getting close' to the traders involved the lower level government officials setting up regular meetings with the traders. Two main municipal government officials were in communication with the Pethikbumi leaders on a regular basis. Ari, the head of the Office for Cooperation and Industry (Dinas Perindustrian Perdagangan dan Koperasi), had previously worked at the Regional Planning Board (Badan Perencanaan Pembangunan Daerah). He was known for his ability to calmly speak and reason with people. Galang was the head of the Marketplace Service (Dinas Pasar) in the city, and was described by the traders as 'well connected' since he ran his own religious school (pesantren) outside of the city. Ari and Galang had both been involved in previous relocations, and had successfully managed to relocate traders even when there was resistance.

On a number of different occasions the Relocation Team of government officials came to the street at 10:30 p.m. to meet with the traders. They sat on straw mats on the sidewalk alongside the traders and chatted for hours. An important aspect of these meetings was making the traders feel like they had access to the officials, and that at some point in the future they might be able to contact them for help. One trader from the Independent group invited the

17 Pethikbumi held demonstrations demanding to meet directly with the mayor because they hoped that by meeting with him face-to-face he might be willing to reconsider the project. Largely inaccessible for months during the project, the mayor in the end did meet with the traders, but by then they felt that they had little choice but to accept the relocation. 
various government officials, including the mayor, to his daughter's wedding (the mayor did not attend), perhaps to illustrate to his family and community that he had connections with the government.

Besides 'getting close' to the traders, socialization was also seen as an attempt to show the traders how sincere the government was. In the meeting mediated by the Regional Ombudsman Office, Ari said, 'We really truly believe in economically empowering the people. If we are talking about Cokroaminoto Street [where Kuncen Marketplace was located], I think in two or three years' time it will be an area of rapid growth and development and will become a premium area.' Galang, following Ari, also explained that the government wanted to empower the traders, which was why the traders would not have to pay retribution for the first six months in the new marketplace, and after that, they would only have to pay a small amount. 'The government is giving a big subsidy to the community for the economic empowerment of the people. That is what the government is really like,' Galang explained (Regional Ombudsman Office, personal communication, 11 September 2007). In the marketplace the traders would pay a retribution fee daily only after six months. Prior to the relocation the traders did not have to pay any 'rent' or 'retribution' fee to the government; they merely paid membership fees to the trader organization and for their use of electricity. The Pethikbumi leaders declared that they were ready and willing to pay a fee to the government for selling on Mangkubumi Street.

For Galang and Ari, sosialisasi was also a selling job. Galang described what he thought the process of sosialisasi involved during a meeting with an Ombudsman organization:

It is like I am a salesperson and I am going to tell you about a product that is good. If you drink this you will be strong. Whether a prospective buyer wantsit or not is anotherissue. If we used a method that was not acceptable, then that would be a problem. Otherwise, let the process continue. We are consulting [with the traders] either informally or formally, and will do this more intensively in the coming months as we approach the end of October.... Weneed to continue because lots [of traders] still do not understand.

GALANG, personal communication, 11 September 2007

Government officials most often explained the resistance to the relocation as a lack of understanding. With more socialization the traders would change their minds, they believed, and therefore the government's job was to sell this project to them. This idea of sosialisasi as selling appears in the Post-Suharto era in reports such as the Socialization of Halal Products with Provincial Sumbar Civil Servants (Yenrina, n.d.). The mayor also described to me during an interview 
how sosialisasi was like selling a product. He described what he said to the traders, 'Please go ahead and compare the promise I have made you with the promise made by the NGOs. Which one is more logical? If [the promise] is not realized, is it easier to prosecute the NGOs or me?' 'So I influenced them by asking, which is more rational? It was like selling a product' (H. Zudianto, personal communication, June 2008).

Whereas to the officials, sosialisasi was a sales pitch, to the Pethikbumi traders it was a process that should involve the exchange of documents, and a meaningful, two-way communication before the plans were made. The new Pethikbumi leaders who took power in November 2006 argued that they had not received enough socialization, more particularly that the government had not provided them with a clear concept of the relocation plan in writing. Like the government had feared, Pethikbumi publically announced that they were 'refusing the relocation' in January 2007, and they organized a handful of demonstrations, high-level meetings, and press events. They critiqued the fact that the government had not met with them often enough, and had yet to provide any concrete plan in writing. One of the new leaders of Pethikbumi explained, 'We had a principle: We thought that if the government wants to promise us this, it must be written down.... It must be written in black and white...' (Adang, personal communication, 14 August 2013).

Besides taking the municipal government to task for not giving them the plan in writing, they also criticized a regulation affecting the relocation that did appear in writing without their knowledge or input. In July 2007, Pethikbumi learned that a new regulation that would officially make selling on Mangkubumi Street illegal had been drafted without their knowledge (Perda No. 45, 2007). Prior to this time, they did not have official permits, but there was no written regulation banning them from selling either. This new regulation would give the government the legal authority it needed to relocate the traders in the upcoming months. Pethikbumi and its supporters argued that it was illegal for the government to produce this document without prior sosialisasi since new legislation required the government to consult with groups it impacted. As a result, five members of Pethikbumi took the mayor to court for breaking the law. After holding a protest outside of the courts, it was written in the newspaper, 'the traders feel that the regulation breaks the law because it was done without a process of rationalization and socialization. The reason for the programme is to make the area green (taman), but from their [the traders] perspective it is only to evict traders' ('Sidang Gugat' 2007).

To the discomfort of the government officials, the traders and their supporters requested the involvement of a third party in the sosialisasi process. After filing the court case, Pethikbumi supporters' recommended that they write to 
the Provincial Ombudsman (Lembaga Ombudsman Daerah or LOD) about their case and request that the ombudsman both investigates and acts as a mediator for their case. In September 2007, the ombudsman brought Pethikbumi and the government Relocation Team together to facilitate the sosialisasi process. In these meetings, Pethikbumi criticized the government for not giving them written copies of the relocation concept in a timely fashion, for not listening to their plan that proposed regulating the trade on Mangkubumi Street instead of relocating the traders, and for producing this regulation without consulting them. Asked to respond, the two main government officials, Ari and Galang, both argued that they were currently in the process of socializing and that they were planning to intensify their communication with Pethikbumi. Ari argued, however, that the government developed the regulation without consultation because it was a technical matter, an area that required specific expertise.

This new mediator thus forced the government to justify and explain its approach to socialization ('Pemkot Sebar' 2007). ${ }^{18}$ The officials responded to these criticisms by arguing that they were in the middle of the sosialiasi process. The idea that they were holding the meetings, or socializing, with the traders was often more important than what actually happened or was discussed in the meetings. In many of the meetings I attended, the municipal government promised the traders that there would be more meetings and opportunity of socialization, deferring the process of agreement or understanding to some future date.

Although Pethikbumi was pushing the boundaries of sosialisasi, the organization had their own problems of sosialisasi with its members. Pethikbumi leaders too were expected to inform and consult with their members about their activities. But it did happen that sometimes the leaders told them versions of the truth that were convenient to themselves. This practice, strikingly, was not discouraged by one of their NGO partners, who said in a meeting, 'I hope that our friends that are here will really promise to socialize (mensosialisasikan), ${ }^{19}$ and give the members information about what we have

18 Following the facilitation of two meetings, the ombudsman generated a series of recommendations, including the idea that the municipal government should reconsider its plans in order to recognize Pethikbumi, and that the municipal government should carry out intensive communication in order to create a win-win solution. They also recommended that the new regulation (Perwal No. 45 2007) should be postponed until Pethikbumi and the government could see eye to eye on the matter.

This is the transitive verb for socializing in Bahasa Indonesia. 
spoken about this evening. But you do not need to share things that might scare them' (NGO Network, personal communication, September 2007). ${ }^{20}$

During internal Pethikbumi meetings, the leaders increasingly placed pressure on their members. Often in these meetings a discourse of 'traitor' (pengkhianat) and 'enemy' (musuh) was used to describe those who had decided to switch sides and support the relocation. In one late night meeting a leader said: 'I am here asking for you to stay strong and not to become a traitor and to defend Mangkubumi Street with everything (mati-matian)' (Pethikbumi, personal communication, 6 November 2007). The Pethikbumi leaders also threatened their members, warning that if they joined the relocation they would not be given a selling location on Mangkubumi. As Aspinall and Weiss (2012:14) suggest, civil society can be a place for the 'reproduction of social inequality as it is a site from which that inequality is challenged'.

Despite recommendations from the ombudsman and the court case against the mayor, the relocation project went ahead as planned with only a short delay of ten days. The traders refusing the relocation increasingly feared that they might be left with nothing if they did not quickly join the relocation. The government also banned them from selling on Mangkubumi and placed two kinds of police on the street to keep traders from returning to Mangkubumi. ${ }^{21}$ With little hope left and no income, the Pethikbumi leaders finally decided to accept the relocation. In exchange for being allowed to join the relocation they were forced to drop the court case. ${ }^{22}$ In the days before Pethikbumi's members entered the marketplace, the mayor announced that the traders had not wanted to move because they had not understood. As a result, they should not be viewed as enemies. When they finally agreed to the relocation, the project was taken as a success; the conflict had been resolved because now they 'understood' as the result of the government's successful socialization process. (Pemerintah Kota Yogyakarta 2007).

In March 2014, a couple ex-Pethikbumi traders were asked to reflect on the term sosialisasi and its use during the relocation. They compared the process of sosialisasi during the relocation to the approach used during elections

20 The NGOs, legal aid organization and university student supporters were concerned that Pethikbumi's leaders were not socializing enough with the members, and that they were resembling their predecessors by acting on their own will, based on imagined support they actually might not have.

21 They were police from Potables (Kepolisian Kota Besar, the Central Police Department, Yogyakarta) and Satpol pP (Satpol Pamong Praja, Public Order police), the latter of which is responsible for overseeing the laws related to the city.

22 The group submitted an official document to the courts withdrawing the case (10/ PENTUN/2007/PTUNYK). 
(sosialisasi pemilu). ${ }^{23}$ According to them, sosialisasipemilu (and other kinds of sosialisasi especially those used in agricultural projects) is a technical necessity to make sure the 'people' (rakyat) know what to do during the election. However, for issues that involve their livelihoods like on Mangkubumi Street, the meaning of sosialisasi should not stop at informing (pemberitahuan). To pass a new regulation, the government needs to undertake sosialisasi with various stakeholders. The process of sosialisasi in this case meant a process of discussion and dialogue between all the parties involved. Joko said that sosialisasi is not important to him if the policy (kebijakan) has already been passed. This was different from what happened in 2012, when the municipal government attempted to pass a regulation on marketplaces in the city (Draft Regulation on Marketplaces or Rancangan Peraturan Daerah tentang Pasar). In the formulation of the regulation, they did a 'uji materi' (judicial review) and invited representatives from each market. Joko was sent as representative from Kuncen Marketplace. However, in 2014 he still had not heard what was happening with the regulation.

Reflecting on the emergence of the municipal regulation (Perwal No. 45) back in 2007, Joko said that the state acted as if it had more knowledge about the best solution for the city, while the traders were not fully involved. He again called it 'demokrasi semu' (fake democracy), and explained that democracy should mean partisipasi rakyat (the participation of the people), but what had happened was a mere false/pseudo-participation (partisipasi semu). With farmers, for example, Suharto's regime used the term penyuluhan or counselling often. It is still used now, but usually only in agriculture, whereas in the city sosialisasi is used more widely. According to Joko, the term sosialisasi is still being used in a manner more or less similar to the way it was used during the New Order era. ${ }^{24}$

\section{Conclusion}

Pethikbumi had many reasons for refusing the relocation. They believed that they should not have been asked to relocate, as traders from other areas had not been asked, that relocations often fail to improve the livelihoods of traders,

23 I want to thank Elan Lauzardi for collecting this data on 5 March 2014, in Kuncen Marketplace.

24 Joko said that the main difference with the New Order was that people who resisted or rejected the government's plan during the New Order were likely to be kidnapped, jailed or even killed, or simply disappeared, while since the Reformasi, they could be evicted or threatened by thugs. In his opinion, this was more or less the same. 
and that the government had waited too long before banning them from selling. These concerns were not about the law. The argument that the government had failed to properly socialize the traders about this project positioned the traders alongside other citizens in Indonesia who now had the right to be informed and consulted. The term sosialisasi, a concept and practice from the New Order, was now being considered a right rather than a benefit the government might provide to the population. Moreover, the term took on new meanings through its usage by citizens and government officials, who were deploying the term to their own, different, ends. However, as examples above have shown, the discourse on sosialisasi, or perhaps more accurately, the results of the usage of this term, might not be as novel as those involved in the relocation imagined.

In the introduction to this book, Berenschot, Schulte Nordholt and Bakker (2017) argue that citizenship studies have often paid far too little attention to the form that democratic citizenship takes in non-Western states. They argue that the concept of individualistic and independent citizens has not had much currency in Southeast Asia, and that there is a need to study what democratic citizenship looks like on an everyday basis in places like Indonesia. This chapter has sought to show the impact that democratic reforms are having on Suharto-era, established forms of state - citizen interactions. The case that I have presented here illustrates that groups such as street vendors are working with legal aid and community organizations to widen the public sphere, and are using sosialisasi, a term from the New Order period, as a central means to engage in a more active defence of citizen rights.

The Pethikbumi traders who joined the relocation perceived the government's process of sosialisasi to be similar to the New Order period. It involved face-to-face communication with the traders listening to the government's plans. Although they met with government officials numerous times, in the end they were essentially forced to follow the government's proposal. Unlike during the New Order period, however, the traders had access to a number of new resources, which made the government's job much more difficult. First, the traders had access to a series of civil society organizations that helped them formulate and make demands in relation to the law. Although the traders might have been illegal, they still had rights as citizens to be properly consulted. Second, their supporters helped them to access institutions such as the court and an ombudsman organization. Channelling their resistance through these institutions gave the traders' claims greater legitimacy. Rather than trying to claim their rights through back-door deals, the traders thus sought to use new laws passed since Reformasi to formally challenge the project.

From the perspective of the government officials, their socialization process was a success: they eventually relocated the traders as planned. The discourse 
of sosialisasi can, on one level, be read as a legitimizing strategy used by the government to justify how they carried out the relocation by saying that they consulted with the traders. It can be further viewed as creating an image of participation documented in so many development projects around the world (Mosse 2005; Sivaramakrishnan 2008). However, it appears to be a continuation of the New Order practice in which the government and interested parties carried forward projects, claiming to have consulted with the stakeholders, when in reality they simply used socialization to persuade those stakeholders to agree with their own viewpoint. From my observation of these sosialisasi meetings the government was often more concerned with holding them, and saying they had met with the traders, rather than really dealing with any of the traders' concerns substantially. It was different in the sense that the government officials were under greater pressure from the public, NGOs and the traders to meet with the latter and socialize this project, than they would have been during the New Order period.

Unlike in the past, there is a new group of middle-class activists willing to help marginalized groups, and a new set of institutions through which their grievances can be voiced. In a certain way, the traders became clients of the activists, and mobilized these relations to effectively communicate their rights. These relationships are informal but legal, and suggest that street vendors are considered as members of civil society in certain contexts (see Chatterjee 2004). In the Reformasi era, street vendors are attaching new democratic expectations to the term sosialisasi. They are using this term to make claims for more transparency and information as well as a more meaningful consultation process when it comes to government plans that impact their livelihoods. Yet, despite their expectations for the municipal government's practices of sosialisasi to change, at various moments they also imitated some of the very practices when dealing with internal dissent. Finally, sosialisasi can be considered a 'halus' or soft way of protesting; by saying that the plan had not been socialized the traders avoided saying in a direct manner that they opposed the relocation plan. Such a use of the term thus avoids an adversial approach.

\section{References}

Afifah, R. (2012, April 1). Ngobrol dengan PKL, Jokowi Janji Tak Ada Pengguran. Kompas. Retrieved from http://www.kompas.com.

Aspinall, E. (2013). A nation in fragments: Patronage and neoliberalism in contemporary Indonesia. Critical Asian Studies, 45(1), 27-54.

Aspinall, E., \& van Klinken, G. (2011). The state and illegality in Indonesia. Leiden: KITLV Press. 
Aspinall, E., \& Weiss, M. (2012). The limits of civil society: Social movements and political parties in Southeast Asia. In R. Robinson (Ed.), Routledge handbookfor Southeast Asian politics (pp. 213-228). New York: Routledge.

Bangun, A. (1994). Sejarah Berdirinya Koperasi Tri Dharma, Persatuan Pedagang Pinggir Jalan Yogyakarta [History of the establishment of Tri Dharma Cooperative in Yogyakarta, Roadside Traders Association]. Yogyakarta.

Barker, J. (1998). State of fear: Controlling the criminal contagion in Suharto's New Order. Indonesia, 66, 7-43.

Barker, J. (2006). Vigilantes and the state. Social Analysis, 5o(1), 203-207.

Barker, J. (2009). Negara beling: Street-level authority in an Indonesian slum. In G. van Klinken \& J. Barker (Eds.), State of authority: The state in society in Indonesia (pp. 47-72). Ithaca, NY: Cornell Southeast Asia Program Publications.

Barker, J., \& van Klinken, G. (2009). Reflections on the state in Indonesia. In G. van Klinken \& J. Barker (Eds.), State of authority: The state in society in Indonesia (pp. 17-45). Ithaca, NY: Cornell Southeast Asia Program Publications.

Basorie, W.D. (2011, April 28). Indonesia Freedom of Information law's [sic], one year on. The Jakarta Post. Retrieved from http://www.thejakartapost.com.

Berenschot, W., Schulte Nordholt, H. \& Bakker, L. (2017) Citizenship and Democratization in Postcolonial Southeast Asia. In: W. Berenschot, H. Schulte Nordholt, \& L. Bakker (Eds.) Citizenship and Democratization in Southeast Asia (pp. 1-32). Leiden: Brill Publishers.

Chatterjee, P. (2004). The politics of the governed: Reflections on popular politics in most of the world. New York: Columbia University Press.

CV. AKA (Konsultan Perencana dan Pengawas Bangunan). (2005). Laporan akhir: Kegiatan rancang bangun asset daerah, pekerjaan penyusunan (FS) eks Pasar Kuncen [Final report: Regional assets building design activities, compiling work for exKuncen Market]. Yogyakarta.

Dinas Pasar Yogyakarta. (2013). Pasar Klithikan Pakuncen: Pusatnya klithikan Yogyakarta. Profile pasar tradisional kelas 2 dan kelas 3 Kota Yogyakarta [Kuncen Second-hand Marketplace: Yogyakarta's Centre for Second-hand Merchandise. Profiles of class 2 and class 3 traditional marketplaces in Yogyakarta City]. Yogyakarta, Indonesia.

Dipa, A. (2012, January 18). Bandung to regulate street vendors. The Jakarta Post. Retrieved from http://www.thejakartapost.com.

Dwi, S. (2013, November 14). Over 800 street vendors relocated. The Jakarta Post. Retrieved from http://www.thejakartapost.com.

Education for a civil society. (1999, October 9). The Jakarta Post. Retrieved from http:// www.thejakartapost.com.

Ford, M. (2009). Workers and intellectuals: NGOs, trade unions and the Indonesian labour movement. Singapore: NUS Press.

Gibbings, S. (2013). Unseen powers and democratic detectives: Street vendors in an Indonesian city. City \& Society, 25(2), 235-259. doi: 10.1111/ciso.12018. 
Gugatan TUN Perawal No. 45 Tahun 2007. (2007, October 10). Badan Pelindung Hak Kemanusiaan.

Gupta, A. (2012). Red tape: Bureaucracy, structural violence, and poverty in India. Durham: Duke University Press.

Hadiwinata, B. (2004). The politics of NGOs in Indonesia: Development democracy and managing a movement. London: Routledge.

Hamid, A., Suprapti, M., \& Bale, D. (1987). Sosialisasi pada perkampungan miskin daerah Sulawesi Selatan [Socialization in poor neighbourhoods of South Sulawesi]. Sulawasi, Indonesia: Departemen Pendidikan dan Kebudayaan, Proyek Inventarisasi dan Dokumentasi Kebudayaan Daerah.

Hammado, T. (1979). Sektor informal diJakarta [The informal sector in Jakarta]. Jakarta, Indonesia: Universitas Indonesia, Pusat Latihan Penelitian Ilmu Ilmu Sosial Jakarta.

Hansen, T.B., \& Stepputat, F. (2001). States of imagination: Ethnographic explorations of the postcolonial state. Durham, NC: Duke University Press.

Hill, D. (2006). The press in New Order Indonesia. Jakarta: Equinox Publishing.

Holston, J. (2008). Insurgent citizenship: Disjunctions of democracy and modernity in Brazil. Princeton, NJ: Princeton University Press.

Human Rights Watch. (2002, December). Breakdown: Four years of communal violence in Central Sulawesi. Indonesia, 14(9)(C). Retrieved from https://www.hrw.org/ reports/2002/indonesia/indonesian102.pdf.

Humphrey, C. (2004). Sovereignty. In D. Nugent \& J. Vincent (Eds.), A companion to the anthropology of politics (pp. 418-436). Malden, MA: Blackwell Publications.

Ichsan, M. (1982). Sebab-sebab timbulnya pedagang kakilima dan usaha-usaha penanggulangannya [The causes of the emergence of street vendors and the efforts to address it]. Malang: Malang Universitas Brawijaya, Direktorat Jendral Pendidikan Tinggal Departemen Pendidikan dan Kebudayaan.

Janowitz, M. (1975). Sociological theory and social control. American Journal of Sociology, 81(1), 82-108. doi: 10.1086/226035.

Jellinek, L. (1991). The wheel of fortune: The history of a poor community in Jakarta. Sydney: Asian Studies Association of Australia in Association with Allen and Unwin.

Jessup, H. (1985). Dutch architectural visions of the Indonesian tradition. Mugarnas, $3,138-161$.

Kementerian Perhubungan Republik Indonesia. (n.d.). Sosialisasi program retrukturisasi angkutan umum massal. Retrieved from http://m.dephub.go.id/read/kolom -redaksi/sosialisasi-program-retrukturisasi-angkutan-umum-massal-15112.

Konsep Pasar Klithikan Dinilai Kurang Jelas: Tolak Relokasi, Pethikbumi Datangi Dewan. (2007, March 17). Kedaulatan Rakyat, p. 2.

Kusno, A. (2005). The significance of appearance in the Zaman Normal, 1927-1942. In F. Colombijn, M. Barwegen, P. Basundoro, \& J.A. Khusyairi (Eds.), Kota lama, kota baru: Sejarah kota-kota di Indonesia sebelum dan setelah kemerdekaan 
[Old city, new city: The history of the Indonesian city before and after independence] (pp. 493-521). Yogyakarta, Indonesia: Ombak Press.

Kuwado, F. (2013, November 20). Dukung ERP, Anggota DPRD DKI Inginkan Adanya Sosialisasi. Kompas. Retrieved from http://www.kompas.com.

Liu, H. (2012, March 8). Presiden tak senang kaki lima digusur. Kompas. Retrieved from http://www.kompas.com.

Lund, C. (2011). Fragmented sovereignty: Land reform and dispossession in Laos. The Journal of Peasant Studies, 38(4), 885-905. doi: 10.1080/03066150.2011.607709.

Manifesto Politik. (2001). Pergerakan Pemuda Indonesia untuk Perubahan. Yogyakarta, Indonesia.

Maryati, K., \& Suryawati, J. (2006). Sosiologi untuk SMA and MA kelas X. Jakarta, Indonesia. PT. Gelora Aksara Pratama.

Masalah pedagang kaki lima di kodya Bandung dan penertibannya melalui operasi Tibum [The problem of street vendors in Bandung muncipality and their ordering through the opertion of Tibum] (1980). Bandung, Indonesia: Universitas Katolik Parahyangan.

Massa, M. (2013, March 23). Hatta Radjasa: Negara Melindungi PKL. Kompas. Retrieved from http://www.kompas.com.

Mosse, D. (2005). Cultivating development: An ethnography of aid policy and practice. London: Pluto Press.

Nordholt, S. (2003). Renegotiating boundaries: Access, agency and identity in postSoeharto Indonesia. Bijdragen tot de Taal-, Land- en Volkenkunde, 159(4), 550-589.

Ong, A. (1999). Flexible citizenship: The cultural logics of transnationality. Durham, NC: Duke University Press.

Pemberton, J. (1994). On the subject of "Java." Ithaca, NY: Cornell University Press.

Pemerintah Kota Yogyakarta. (2007, November 13). Walikota Berharap Pasar Klithikan Membawa Berkah. Retrieved from http://www.jogjakota.go.id/index/extra.detail/ 1694/walikota-berharap-pasarklithikan- membawa-berkah.html.

Pemerintah Kota Yogyakarta, Kantor Pengendalian Dampak Lingkungan. (2004). Rencana pembangunan Pasar Kuncen [Kuncen Market development plan]. Yogyakarta, Indonesia.

Pemkot Sebar Surat Pemberitahuan Relokasi: Pethikbumi Lakukan Aksi, 10 Ribu Tanda Tangan. (2007, October 28). Kedaulatan Rakyat. Retrieved from http://www .ombudsman-asahan.org.

PT. CIPT Nindita Buana (2005). Laporan akhir: Rancang bangun eks Pasar Hewan Kuncen [Final report: Engineering/building design and construction of ex-Kuncen Livestock Market]. Yogyakarta.

Purdey, J. (2006). Anti-Chinese violence in Indonesia, 1996-1999. Honolulu: University of Hawai'i Press. 
Rajasa, H. (2013). Hatta Siap Lindungi PKL. Retrieved from http://hatta-rajasa.info/ $\mathrm{read} / 1504 /$ hatta-siap-lindungi-pkl.

Reerink, G. (2009). When money rules over voice: Regional autonomy and spatial planning in Bandung benefits the elite. Inside Indonesia, 98, October-December. Retrieved from http://www.insideindonesia.org.

Ryter, L. (2009). Their moment in the sun: The new Indonesian parliamentarians from the old OKP. In G. van Klinken \& J. Barker(Eds.), State of authority: The state in society in Indonesia (pp. 181-218). Ithaca, NY: Cornell Southeast Asia Program Publications.

Salamun, T. (1993). Sosialisasi pada perkampunganyang miskin di kota Yogyakarta [The socialization in poor neighbourhoods in the city of Yogyakarta]. Yogyakarta, Indonesia: Departemen Pendidikan dan Kebudayaan, Direktorat Jenderal Kebudayaan, Direktorat Sejarah dan Nilai Tradisional, Proyek Penelitian, Pengkajian dan Pembinaan Nilai-Nilai Budaya.

Satpol PP Tak Pakai Cara Kekerasan. (2012, October 31). Kompas. Retrieved from http:// www.kompas.com.

Sidang Gugat Wali Kota Ditunda, PKL Kecewa Dinilai Cacat Hukum. (2007, November 8). Suara Merdeka. Retrieved from http://www.suaramerdeka.com.

Simandjuntak, D. (2012). Gifts and promises: Patronage democracy in a decentralized Indonesia. European Journal of East Asian Studies, 11(1), 99-126.

Sinombor, S. (2008, March 1). Joko Widodo dan Misi Mengorangkan Wong Cilik. Kompas. Retrieved from http://www.kompas.com.

Sivaramakrishnan, K. (2008). Crafting the public sphere in the forests of West Bengal: Democracy, development and political action. American Ethnologist, 27(2), 431-461. doi: 10.1525/ae.2000.27.2.431.

Sosialisasi. (n.d.). In IndoAdvisors. Retrieved from http://www.indoadvisors.com/sosia lisasi.html.

Strassler, K. (2004). Gendered visibilities and the dream of transparency: The Chinese Indonesian rape debate in post-Suharto Indonesia. Gender and History, 16(4), 689-725. doi: 10.1111/j.0953-5233.2004.00361.x.

Sumarno. (1992). Peranan sekolah dalam proses sosialisasi politik: Studi pembinaan sikap dan kesadaran berbangsa bernegara siswa tingkat sekolan menengan sertã faktor-faktor yang mempengaruninya di wilayah Jawa Tengah dan Daerah Istimewa Yogyakarta: Laporan Penelitian [The role of schools in the process of political socialization: The study of attitudes and awareness toward the nation among middle school students and what affects them in Central Java and the Special Region of Yogyakarta: Research Report]. Yogyakarta, Indonesia: Fakultas Ilmu Pendidikan, Institut Keguruan dan Ilmu Pendidikan Yogyakarta.

Sumarsono, M. (1987). Sosialisasi pada perkampungan miskin (struktur keluarga dan sosialisasi) di Kotamadya Padang [Socialization in poor neighbourhoods (family 
structures and socialization) in the city of Padang]. Padang, Indonesia: Departemen Pendidikan dan Kebudayaan.

Telle, K. (2009). Dharma power: Searching for security in post-New Order Indonesia. Social Analysis, 53(1), 141-156. doi: 10.3167/sa.2009.530109.

Traders brace for eviction. (2008, January 17). The Jakarta Post. Retrieved from http:// www.thejakartapost.com.

Waworoentoe, W.J. (1975). Markets and communities in Jakarta and Bandung. Bandung: Institut Teknologi Bandung.

Yenrina, R. (n.d.). Sosialisasi Produk Halal Bersama Pegawai Pem-Prov Sumbar [Web $\log$ post]. Retrieved from http://www.halalmui.org/newMUI/index.php/main/ detil_page/8/1333.

Yusrizal \& Nurharmi. (1997). Sosialisasi politik masyarakat desa: Studi kasus di Desa Sunur Timur, Kecamatan Nansabaris: Laporan penelitian [Political socialization in rural communities: A case study in the village of East Sunur, Nansabaris District: Research report]. Fakultas Keguruan dan Ilmu Pendidikan, Lembaga Penelitian dan Pengabdian Masyarakat, Universitas Bung Hatta. 
PART 2

Identity and Citizenship 
978-90-04-32966-9

Downloaded from Brill.com $\odot 4 / 26 / 2023$ 12:50:28PM via free access 


\title{
Militias, Security and Citizenship in Indonesia
}

\author{
Laurens Bakker
}

The first of June is Indonesia's annual Pancasila Day. It is celebrated in commemoration of Soekarno's presentation on 1 June 1954 of Pancasila, the philosophical foundation of the unity of the Indonesian state, embodying ideals of its society and citizenry. ${ }^{1}$ The day, generally, has dignitaries delivering speeches on the state of Indonesia and the nature of Pancasila. Speaking at a meeting at the People's Constitutive Assembly (MPR) on Pancasila Day 2012, VicePresident Boediono reminded his audience that, for the continued existence of Indonesia as a nation, creating unity in diversity and finding ways to live together harmoniously were crucial. Ethnic and religious differences should not stand in the way of Indonesian unity as exemplified, Boediono suggested, by the friendship of Soekarno - a Muslim - with Catholic priests during his exile in Flores in 1938. Religious fanaticism, Boediono warned, is a threat to the nation and to the peace of religious minorities (Aritonang, 1 and 2 June 2012).

Pancasila's emphasis on unity is Indonesia's ultimate ideological source of authority and, as such, is supposed to guide and pervade all legislation. In the preamble of the constitution, the elements of Pancasila are given as (1) belief in the one and only God, (2) a just and civilized humanity, (3) the unity of Indonesia, (4) democratic rule that is guided by the power of wisdom resulting from deliberation and representation and (5) social justice for all the people of Indonesia. ${ }^{2}$ These elements, clearly, have strong links to more well-known aspects of citizenship (such as protection by the state, a say in government and the sustaining relationship of community), but Pancasila is nevertheless hit by

1 This chapter is based on research conducted as part of the research project State of Anxiety: A Comparative Ethnography of Security Groups in Indonesia which was supported by the Netherlands Organisation for Scientific Research (grant number 463-08-003). Fieldwork and interviews were carried out between 2007 and 2013. Groups involved were Brigade Manguni, Komando Pertahanan Adat Dayak Kalimantan (KPADK, Dayak Customary Defence Command), Gerakan Pemuda Asli Kalimantan (GEPAK), Movement of Indigenous Youth of Kalimantan), Pemuda Pancasila, (Pancasila Youth) Garda Pemuda Nasional Demokrat (GP NasDem, National Democrats Youth Guard) and, to a lesser extent, Front Pembela Islam (Islamic Defenders Front) and Front Betawi Rempug (Betawi Brotherhood Front).

2 Based on a certified English translation available at the website of the Asian Human Rights Commission at http://www.humanrights.asia/countries/indonesia/countries/indonesia/ laws/uud1945_en. 
the persistent critique that its formulation is open to multiple interpretations and explanations along different political lines (see, for example, Wahyudi 2006). When Soekarno's successor, Suharto, imposed Pancasila as the nation's sole ideological basis, it was found that others were prevented from using the philosophy as an umbrella under which to maintain diverging ideologies (Ward 2010:30-31). This usage of Pancasila, therefore, served as a strong means to curb opposition, substantiate the regime's view on national and societal stability and legitimate control over the economy. These were then enforced by political, administrative and, where necessary, violent means.

The sudden end of Suharto's New Order regime in 1998, and the ensuing reformation politics, sparked a critical debate on the sources, applications and legitimations of public power. These debates centred on the (il)legitimate usage of government authority by state officials, and the state's weakness in upholding the rule of law in prosecuting abuses of government authority (Sakai 2002; Aspinalland Fealy 2003; Kingsbury and Aveling 2003; Schulte Nordholt and Van Klinken 2007; Aspinall and Mietzer 2010). A shared finding was the notion that there was little reason to assume that the weakening of the authoritarian central state would naturally result in democratic rule or increased civil awareness. In fact, factions of the regime, headed by powerful and wealthy individuals, managed to reorganize in the face of reform and continued their hold on economic and political influence (Robison and Hadiz 2004:18-252). Schulte Nordholt and Van Klinken (2007:24-25) referred to such regime patrons controlling the law and government agencies as a 'shadow state' of authority that exists beyond the institutions of government proper. The confrontation between these established power structures and the decentralization, democratization and advancement of civil society gave rise to a 'renegotiation of boundaries of authority' (Schulte Nordholt and Van Klinken 2007) between these established power holders and the new ones emerging as a result of democratic elections. This struggle, between patronage and clientelism on the one side and democratic reforms on the other, predates 1998. Almost from independence onwards, attempts to establish parliamentary democracy as Indonesia's system of government were seriously hampered by corruption, patrimonialism and client-patronage networks. Schulte Nordholt (2014) analyses this development using a longue durée perspective, which leads him to identify the current situation in Indonesia as a patronage democracy. Chandra (2004:6) defines this as a system 'in which the state has a relative monopoly on jobs and services, and in which elected officials enjoy significant discretion in the implementation of laws allocating the jobs and services at the disposal of the state'. Van Klinken (2009) and Aspinall (2013) note the manifestation of patronage democracy in different capacities - from the leaders who derive their power from the state 
while distributing clientelistic favours along economic, cultural and social lines, to the followers who identify themselves in local, ethnic or communal terms. Thus, a leader's authority is established by the democratic process and affirmed by their proven capacity to deliver.

An eye-catching element in the current phase of renegotiation is the increased social prominence of civil, militant organizations. These are organized, disciplined and uniformed bodies that generally represent specific religious or ethnic groups or are affiliated to political parties as dedicated security forces. They fall under the broad category of organisasi kemasyarakatan (societal organizations; abbreviated to ormas). ${ }^{3}$ Most of these organizations state their goals as specifically protecting the interests of the groups they represent, while simultaneously striving for a peaceful and united Indonesia. They generally proclaim Pancasila and the unity of the Indonesian state to govern their activities, thus nominally placing themselves within the ideological order of the state. ${ }^{4}$ Offering protection to the needy, ensuring peace and order, respecting the wishes of the local population and ousting bad influences are ormas activities that can be linked directly to the national philosophy. 'We work with all for the good of Indonesia and Pancasila, and strive to eradicate threats to the nation and the people,' Fary Malunda, a senior leader of the ormas Brigade Manguni told me, adding that Indonesia's famous diversity needs to be protected. While such statements could be seen as mere lip service to the national state and as 'cover-ups' of what amounts to the appropriation of state authority, it is very hard for such organizations to get anywhere without the support of the population, whose good Malunda proclaimed to have at heart.

In this chapter, I seek to come to terms with the role of ormas, particularly as forces that balance reactionary and pro-democracy interests as well as (often) furthering their own agendas. What is the role of ormas in the development of citizenship in Indonesia today? As will be made clear below, New Order-era

3 As a legal category ormas refers to all sorts of societal organizations: from aid foundations and health providers to Greenpeace and the World Wildlife Fund. Clearly, these are not intended here. The exact number of ormas is hard to establish. Nugroho (2013:16) found a staggering 83,727 civil society organizations registered with various ministries, but suspects that there is an overlap among those. Moreover, many of these groups will not be focused on security provision, nor will all security-providing groups have registered. Based on my own interviews with academics and government officials, estimates of 'security-providing ormas' in Indonesia range between 400 and 2,000 groups. These are spread throughout Indonesia but mostly active in urban areas.

4 A notable exception is Front Pembela Islam, whose drive to turn Indonesia into an Islamic state puts it at loggerheads with Pancasila's principles. FPI spokespersons have frequently expressed their discontent with the 'un-Islamic' Pancasila. 
history sees ormas as strongly associated with crime, lawlessness and patrimonialism, which would make them a disturbing and outright undesirable element in a democratic society governed by the rule of law. Increasingly, however, post-Suharto ormas - such as Brigade Manguni - maintain a strong focus on improving local welfare and aiding the community, which gains them popularity and credibility as socially engaged organizations willing to help the needy. On the other hand, as we shall see below, the criminal element has certainly not disappeared. One particular issue that will be scrutinized further is the crucial question: can crime actually serve the community?

The issue that I explore is the position of ormas in the relationship between the individual and the political community. This relationship, as argued in the introduction (Berenschot et al. 2017), is the central pillar of citizenship. It is shaped by 'particular conceptions and practices of rights, reciprocity and representation...' that '... are related to [postcolonial countries'] political economy and a particular history of state formation' (see also this volume's Introduction). As such, the daily practices of citizens' rights and duties in Indonesia have a history of personal relations at odds with the anonymity and accountability essential to Western ideals of state - citizen relations. In the following paragraphs, I discuss several examples of ormas' activities and strategies in order to come to an understanding of their functioning. I will explore their position in society - as serving patrons, or championing the masses - their effect in furthering or hampering the rights and duties of citizenship, and their recourse to violence and crime in doing so.

\section{Security versus Violence}

Most ormas manifest their power and obtain their support by providing security and protection in specific territories. On the street, they maintain a public presence through guard posts and patrols in 'their' neighbourhoods, for which the locals generally contribute a small monthly fee. They beat up and chase out thieves and burglars or, if they turn out to be locals, incorporate them into the organization - thus providing them with a job while enlisting their knowledge and muscle. Outside of the neighbourhoods ormas manifest themselves through rallies, parades or protests, the latter generally against 'bad' influences in public life. These can include media that published 'wrong' stories, politicians who are corrupt or take 'wrong' decisions, entrepreneurs competing with the ormas' supporters, or protesters, land occupiers or other critical voices that go against the interests or principles defended by the organizations. Some ormas, specifically Front Pembela Islam, also target artists whose music, 
performance or writings are 'disapproved of' by the organization. At times, this puts one ormas against another, both for ideological reasons (notwithstanding Pancasila) and in turf wars. ${ }^{5}$ Yet, within their areas, ormas usually undertake a wide range of security-providing activities and neighbourhood assistance, of which Table 6.1 gives an overview.

It is striking that, in most theories of state-building, the provision of security (as well as several of the other tasks listed above) are considered to be functions of the state. In carrying out these tasks, ormas thus display state-like qualities through their appropriation of the mutually constitutive processes of territorial control, authority and citizenship (Lund and Boone 2013:2). Ormas claim territory by providing security, and other services as listed in Table 6.1, to

TABLE 6.1 Overview of ormas community activities and services as observed and reported in Jakarta, East Kalimantan and the Minahasa

\begin{tabular}{|c|c|c|c|c|c|}
\hline & $\begin{array}{l}\text { Front } \\
\text { Betawi } \\
\text { Rempug }\end{array}$ & $\begin{array}{l}\text { Brigade } \\
\text { Manguni }\end{array}$ & $\begin{array}{l}\text { Front } \\
\text { Pembela } \\
\text { Islam }\end{array}$ & $\begin{array}{l}\text { Pemuda } \\
\text { Pancasila }\end{array}$ & GEPAK \\
\hline Guard posts and patrols & $\mathrm{X}$ & $\mathrm{X}$ & $\mathrm{X}$ & $\mathrm{X}$ & $\mathrm{X}$ \\
\hline Security firm for companies & $\mathrm{X}$ & $\mathrm{X}$ & & $\mathrm{X}$ & $\mathrm{X}$ \\
\hline Orphanages and schools & $\mathrm{X}$ & & $\mathrm{X}$ & & \\
\hline Financial aid to the poor & $\mathrm{X}$ & $\mathrm{X}$ & $\mathrm{X}$ & $\mathrm{X}$ & $\mathrm{X}$ \\
\hline Sport events & & $\mathrm{X}$ & & & \\
\hline Prayer meetings & $\mathrm{X}$ & $\mathrm{X}$ & $\mathrm{X}$ & & $\mathrm{X}$ \\
\hline Funeral assistance & & $\mathrm{X}$ & $\mathrm{X}$ & & $\mathrm{X}$ \\
\hline $\begin{array}{l}\text { Emergency relief (fires, } \\
\text { floods, mud slides, etc.) }\end{array}$ & $\mathrm{X}$ & $\mathrm{X}$ & $\mathrm{X}$ & $\mathrm{X}$ & $\mathrm{X}$ \\
\hline
\end{tabular}

5 Front Pembela Islam aims to defend Islam and Muslims against anti-Islamic dangers. The organization is known for smashing up bars and stores selling alcohol, destroying churches and for a drive to oust Ahmadiyahs from Indonesia, all of which it considers social vices. Ansor (in parts of Java) and Brigade Manguni (East Kalimantan and the Minahasa) actively work at keeping Front Pembela Islam out of their areas, as they regard the organization to be a vice in Indonesian society (personal communication by East Kalimantan's Brigade Manguni leader). An example of a turf war are the fights between Front Betawi Rempug and Pemuda Pancasila in Jakarta, which appeared to have gained impetus by the arrests of John Kei (in 2012) and Hercules (in 2013), both established Jakartan crime bosses, and the ensuing weakening of their respective gangs. 
its inhabitants and entrepreneurs. In exchange, they require monthly contributions from the households and businesses in the area. These contributions are generally fairly low, but monthly payments by several blocks of households provide substantial revenue for the ormas. ${ }^{6}$ Their regulatory activities provide ormas with influence in property transactions and in managing (new) entrepreneurs' access to the area. They can also arrange employment and practical training for those in need of it (motor mechanics, motor taxi drivers, shop staff, night watchmen, et cetera) and provide mass manpower when government, the neighbourhood, local entrepreneurs or others require it.

Usually, an area's inhabitants are reasonably positive about such local ormas activities. The presence of ormas guarantees less crime and assistance to the local poor in obtaining work and securing incomes. But this relation with members of ormas can turn sour quickly if the sales staff recommended by the local ormas head is not performing well and is fired. Likewise, a friend living in an upscale part of town in Samarinda (East Kalimantan) told me how the local ormas contacted him when he was extending his house and asked for an extra contribution of $10 \%$ of the building materials' costs. This was, as the ormas declared, because of the extra work the guarding of the building site would require. They settled on $5 \%$. When I asked him whether he felt cheated as he already paid monthly contributions, he replied that this was all part of democracy as the poor were just asking for a share of the wealth. Two days later, he asked passing ormas members to help shift a few stacks of roof tiles, to which they complied without fuss.

Ormas need local supporters in order to gain leverage with local power holders. Their position between the population and the established patrons means that they maintain their influence by engaging with and balancing the needs of both groups. For the common people in the cities and villages, ormas represent local and accessible providers of order and security, who, moreover, can communicate the peoples' needs to those in power, and, if necessary, put pressure on the local administration. For patrons, they are a source of votes, popular support and informal muscle. As such, ormas straddle the balance between democracy and patrimonialism by being accountable to their supporters on both sides for their activities and results. Failure to protect the needs of society

6 Protection fees in the upper middle-class Jakartan area of North Cikini, protected by the ethnic Betawi Forkabi ormas, stood at 50,00o rupiah per month per household in January 2014. Upon payment, which is generally made by the house staff as part of the monthly returning payments for electricity, laundry services and suchlike, Forkabi personnel provide a receipt stating that the contribution to neighbourhood security was paid for that month, as well as the name and signature of the collecting Forkabi member. 
will result in a loss of popular backing and greater dependency on patrons, thus severely limiting an ormas' credibility as a societal movement championing reform and democracy.

These two themes - reform and democracy - are essential elements in ormas' legitimization discourses. In a series of interviews I conducted, various ormas leaders and ormas lawyers explained to me that the provision of security, the monopoly on violence and the authority of the state should not be considered as exclusive domains of the government but rather as tasks with which the government is entrusted by society. If the government fails to do its job, it is up to society to step in and correct the faulty officials and that, these leaders maintained, is what ormas do. Lawyers connected to ormas emphasized that the Indonesian constitution allows Indonesia's citizens to do this (see Bakker 2015:88). It is in the latter framework that ormas spokespersons have presented themselves as the embodiment of the relationship between the political community and the individual. This relationship, defined by mutual rights and obligations - as argued in the Introduction - constitutes the central element of citizenship.

This position is perhaps best appreciated when considered through Abrams' (1988) distinction between the state as a system (the state's tangible institutions) and the state as an idea (that what is expected to make up the state). Ormas are not part of the official state system, which consists of the government apparatus and institutions. Yet, their capacity to act independent from government while legitimizing their actions through appeals to social circumstances, customs and religion, as well as the state, implies that the exercising of public authority in Indonesia is subject to a constant process of contestation and repositioning of institutions, in which new ones come to the fore as others lose influence and disappear (Olivier de Sardan 2005:16). Whereas Soekarno introduced Pancasila as a broad philosophy aimed at promoting national unity, Suharto's imposition of Pancasila as a national philosophy was used as a means to justify state control. Today, the national philosophy is therefore seen as a symbol of unity by some and detested as a means of repression by others. Balancing both democracy and patronage, ormas make use of such ambiguities in Indonesia's unity and reform to legitimize their own authority in guarding the interests of the population.

Herein lies their greatest challenge. Whereas the capacity for violence can be a means to provide security, it is also what security protects citizens from. Weber's observation - that the rise of European cities was closely connected to the combination of a marketplace and the presence of a self-equipped, armed citizenry capable of withstanding the overlord knights (Barbalet 2010:205-206) resonates in ormas' discourse of resisting the power of established elites in the 
name of the population. Yet how do the interests of the population and those of patrons balance out in ormas' provision of security to Indonesia's citizens at large? To answer this question, I will first address the ormas - patron relations from a socio-historical perspective in order to gain a better understanding of the established position of civil violence within the state. This is followed by a paragraph that considers ormas' functioning from the perspective of civil responsibility, public support and embedding in local society. I then continue to look specifically at the evolution of ormas in terms of societal and economic relevance for local society, before offering some concluding thoughts on how ormas' activities relate to citizenship in Indonesia.

\section{Return to Pancasila Day}

On the third of June 2012, a few blocks removed from the M PR Building, another Pancasila Day celebration took place at the National Monument (Monumen Nasional, or Monas). At the event, a two-hour mass rally was held by members and sympathizers of the National Democrat Party (Partai Nasional Demokrat). In his speech, party leader Surya Paloh, a business tycoon and national media owner, emphasized the need for change. He felt that any current social wrong was largely due to the fact that Pancasila was still not the basis of national life (Koran Bali Tribune, 4 June 2012). ${ }^{7}$ Watching the rally on television in a hotel room, I was struck by the large number of uniformed personnel that were present. Row upon row of people clad in black and dark blue uniforms stood to attention in disciplined ranks, their blue berets forming a colourful contrast against the dark background of the uniforms. In the wide-open space around Monas, they presented an image of massed ranks at the ready - to be deployed for a common goal. According to newspaper reports, 25,000 out of the 50,000 people attending belonged to the Garda Pemuda Nasional Demokrat (National Democrat Youth Guard, popularly known as GP NasDem), which was affiliated to the National Democrat Party. Members of the GP NasDem are young, as only the young have - according to the organization's website, that is - the drive and passion to change society. Therefore, the website reads, the young should be courageous and militant in striving for their goal, which is the restoration of the good elements from the past and the rekindling of the reform that started

7 Paloh emphasized the usage of Pancasila for the unity of the nation, as a moral code, as the main source of statehood and as a vision inspiring governance (see Aditya 2012:70-81 for a written-out speech of Paloh that addresses his thoughts on Pancasila along largely similar lines). 
upon the end of dictatorship, but that currently lacks direction and goals. ${ }^{8}$ The Garda's manifesto states that the organization is to be a vanguard for citizenbased democracy, and that its members should exert themselves to the utmost to seize the bright future of a welfare state - bringing liberty, solidarity and equality. ${ }^{9}$

A specific group within the GP NasDem is formed by its rapid reaction force (barisan reaksi cepat) known as BARET: a semi-military unit that can be deployed for the defence of the country and that has been trained by former military (Metrotvnews.com, 15 August 2013). In his Pancasila Day speech, Paloh described BARET's role as pioneers who lead the Indonesian people in guarding Pancasila and in putting a stop to the distortion and demoralization that engulfs the nation (Surya Paloh, cited in Media Indonesia, 4 June 2012). These goals appear fairly abstract, but are in line with the general ormas task of the provision of security. However, BARET members have also been trained in communicating the National Democrat Party's plans and visions. They carried out an ongoing grassroots campaign to mobilize support for the party in anticipation of the 2014 general elections. Furthermore, during the election period, BARET personnel were present at polling stations in order to observe the voting procedures (Metrotvnews.com 2013).

The notion of BARET carrying out a grassroots vote-mobilizing campaign and surveying at polling stations can be understood in two ways. First, one can see BARET as an instrument for intimidating voters on behalf of BARET's patron. Or as a civil organization that initially engages in vote mobilizing, but later moves on to survey procedures at polling stations. The latter task is a task carried out by numerous civil society organizations worldwide.

The image of the mass of ranked and uniformed people present at the National Democrat's Pancasila Day celebration, together with the speech that was delivered at that occasion, reminded me of Pemuda Pancasila (Pancasila Youth), possibly the best known ormas in Indonesia. Clad in distinctive brownorange camouflage uniforms, its members formed a highly visible element of many official occasions during the New Order. Officially, Pemuda Pancasila aims to defend Pancasila and to improve of the moral and economic welfare of marginalized youths, who otherwise eke out a living in the informal economy or in crime. Bringing these youngsters into the fold of the organization, Pemuda Pancasila argues, gives them a chance to better themselves morally

8 http://www.gardapemudanasdem.or.id/suara-muda/207-karakter-pemuda-pelopor-yang -progresif. Last accessed 7 July 2015.

9 See http://www.gardapemudanasdem.org/tentang-kami/manifesto. Last accessed 7 July 2015. 
and to improve their ties with nationalism (Ryter 1998:47). The organization thus combines a rank-and-file of urban poor and petty criminals with visible and moral adherence to the highest ideals of the nation (Ryter 1998:47). The result is a disciplined group of hardened muscle that is willing to act, violently if necessary, for the goals as expressed by the leaders of this ormas.

During the New Order, Pemuda Pancasila developed a working relation with Golkar, the then-dominant political party and Suharto's vehicle. The organization became the embodiment of Suharto's usage of Pancasila as a legitimization of state control. Opponents of the regime were threatened or attacked by Pemuda Pancasila members who were objecting to their 'anti-Pancasila attitude', or repeatedly harassed. Pemuda Pancasila members carried out their patrons' dirty handwork by beating up competitors or clearing inhabitants from new project sites through intimidation, violence and arson. The organization also provided security to businesses, upon the latter's request or forced, as a way of extortion. Members were engaged in theft, prostitution, drug trade and the protection of illegal bars and casinos, yet were largely above the law through their alliances the ruling elite. This relationship normalized Pemuda Pancasila's practices as violence and crime were associated with the regime (see Ryter 1998:48-53; Wilson 2006:266). As protesters marched the streets, calling for Suharto's resignation in 1998, Pemuda Pancasila organized counterdemonstrations and actively contributed to the chaotic violence in Jakarta that was intended to destabilize the capital and the opposition's support.

Pemuda Pancasila is, in the words of Ian Wilson (2010:199), the 'granddaddy' of organized preman groups. 'Preman' derived from the Dutch for 'free man', denotes gangsters or thugs, usually of the street-level variety, whose main modes of income generation are extortion, debt collecting, the vehicle-parking business and the provision of security to local shops and vendors. Indonesia has a history of organized territorial criminal groups (jawara) which are controlled by local strongmen (jago) who act as 'go-betweens' with non-criminal members of society (see Schulte Nordholt 1991). The New Order cracked down heavily on premanism through Pemuda Pancasila as well as through intimidation and the slaughter of thousands of preman by mysterious killers who turned out to be affiliated with the police and the military (see Van der Kroef 1985 and Barker 1998). The one way for preman gangs to operate safely was to ensure beking (backing) from among the higher circles of the regime particularly the police or the army. Patrons would protect 'their' preman in exchange for a percentage of its profits and physical assistance when needed. Such established groups, with Pemuda Pancasila as the best-known example, were both feared and respected in society. Virtually invulnerable to the legal system through their beking, occasional show trails would see preman leaders 
convicted to serving jail terms whenever the regime needed a sterner law and order image, but their sentences were usually drastically shortened as time progressed.

The nationwide mushrooming of security-providing ormas from 1998 onwards is shaped by this recent history. Political parties, with the regime's usage of preman for violent actions in mind, set up task forces (satuan tugas or satgas) such as the NasDem's BARET discussed above, that were charged with the provision of security and order at party events and for party members. Almost all militant ethnic and religious organizations that came into being throughout the nation declared that they were organizations aimed at protecting their supporters: from the greedy elites that had been plundering the country during the New Order, criminals, ethnic violence as well as religious fanatics. These groups were active under a wide variety of names which frequently contained martial terms such as laskar (army), brigade, front or komando, followed by a reference to a religion, an ethnic group, Pancasila or the Indonesian nation.

These ormas argue that they exist to provide the much-needed security to ward off the threat of other groups, which makes them reminiscent of the volunteer neighbourhood watches (ronda) and civilian security groups (such as linmas, hansip and satgas) that have existed in association with the government or the military for most of Indonesia's history as an independent state (see Barker 1999; Kristiansen and Trijono 2005:238-241). This argument also brings Indonesia's long war for independence to mind, which was waged against the Dutch colonial forces by numerous regional militias rather than by a nationwide Indonesian army. In fact, the idea that Indonesia's security is the domain of (local) society as much as of the state is an integral part of the nation's history. It has been made official through the national concepts of sishankamrata (total people's defence and security) and, more recently, sishanrata (universal people's defence), which propagates that the population should join the army, police and government with all possible means to defend the nation. The principle of local civilians who know each other and organize themselves in order to maintain security is thus an established practice ingrained in society as well as in the national defence strategy. The ready availability of trained civilians and the reform-driven withdrawal of military and police influence from civilian affairs makes security very much an issue of local concern. Siegel (1986), writing on the Javanese city of Solo, found that security rather than shared economic interests or kinship ties, was the most active expression of community in the cities' neighbourhoods. Moreover, as regional autonomy turned the region into the locus of political and economic identity, locals were presented with a scale of operation they could take up without government, state, patron, or regime assistance. 
In a 2005 interview, Barnabas Sebilang, then head of the Dayak Customary Council of Kalimantan (Dewan Adat Dayak seKalimantan) to which the Dayak Customary Defence Command (Komando Pertahanan Adat Dayak Kalimantan) serves as a security force, told me how local bands of fighters had fought against the Dutch colonial forces to liberate Indonesia, only to lose control over the development and governance of their areas once the nation was independent and its president established. That control needed to be taken back. Sebilang phrased it thus: 'We have been liberated from the Dutch, now we need to liberate ourselves from the control of Jakarta, from the Javanese.' Surprised, I asked him whether he intended for Kalimantan to become an independent state. He laughed, and told me that such a measure was not necessary at that moment, but that Javanese businessmen supported by the national bureaucracy were plundering the island's natural resources without regard for the national law. His organization was established to ensure that the new political climate would make it possible that Kalimantan's indigenous Dayak population would benefit from the island's resources. The actions of the Komando, he suggested, were nothing less than a fight for the liberation and emancipation of repressed citizens who needed protection of their rights as well as political guidance. This would be achieved by the proper implementation of Pancasila and the Indonesian constitution. Both of those legal sources, he felt, legally entitled the Komando to protect and enforce the rights of the province's Dayak population. I have discussed some of these actions by the Komando in other articles (see Bakker 2009, 2015). They involved issuing threats, applying violence, reclaiming land appropriated from local farmers by plantation companies, and the provision of security to the latter, many of which are, in fact, owned by Javanese businessmen.

Groups like the Komando Pertahanan Adat Dayak Kalimantan exist throughout Indonesia and combine a practical mix of relations to officialdom, a discursive emphasis on ethnic identity, the protection of local society and a dedication to the Indonesian nation with what their opponents claim is 'criminal activism' (such as illegal land re-appropriations). For such groups, societal support rather than patrons is the main source of beking. Massed members and supporters, whose opinions will translate into votes at the next elections, draw governmental attention and therefore affirm such organizations' relevance. The practice of violence, the level of criminality, the professed goals and the ideological underpinnings differ per group, but many groups appear to limit crime and violence as their following grows and become increasingly nonpreman and diverse. As Wilson (2010:201) points out: 'These organizations can simultaneously be violent defenders of reactionary and hegemonic interests and proactive vehicles for the social and cultural advancement of politically 
and socially marginalized communities' (italics in the original). The protection and provision of security to some, sustained by discourses of nationalism, civil rights and democracy, is combined with the threat of violence to others (see Bakker 2016). Popular opinion plays an important role in balancing protection and threat and, as we shall see below, is strongly influenced by the way in which ormas propose to put their muscle to the service of the public interest.

\section{Civil Responsibility, Violence and the Public Gaze}

As I was speaking to a group of Indonesian academics about the National Democrats' Pancasila Day rally a few days after it took place, several of them pointed out that my comparison to Pemuda Pancasila was not fair to the National Democrats' intentions. Surya Paloh, they felt, was one of the 'good guys' of contemporary Indonesian politics. As a long-term member of Golkar, Paloh ran for the position of party presidential candidate for the 2004 presidential elections but lost to New Order strongman army general Wiranto. Although part of the New Order establishment, Paloh was liked by the reformists: he had not been a member of the regime's in-crowd and was not associated with corruption, violence or similar vices. The social involvement of his National Democrat movement - not yet a party in 2004 - further indicated the difference between him and Golkar. In 2011, the National Democrat movement decided to form a political party in order to bring their aspirations into national politics, and Golkar asked Paloh to choose between them and the Democrats. Paloh left Golkar as he felt that the party's decreasing percentage of national votes indicated its failure to effectively engage with the desires of society (see Margianto 2011). In the running-up to the 2014 presidential elections, Paloh repeated his disappointment with Golkar, stating that the party lacked idealism, political rationality and common sense, whereas each cadre of the National Democrat Party was driven by his heart, morality and human compassion (Rosarians 2013). Many of the people with whom I spoke about Paloh positively emphasized his genuine concern, his clean past and his potential for bringing about change.

During interviews people also pointed out that although the BARET rapid reaction force was indeed useful to protect party rallies from attacks by thugs sent by Paloh's enemies, as a trained organization it left much to be desired. BARET could hardly be considered an ormas of Pemuda Pancasila standards, they felt. They had witnessed how the parade by members of BARET on the third of June had lacked in uniformity of movement and speed. This only showed, they argued, how difficult it is to discipline and train civilians. This 
did not, though, lead them to doubt Paloh's capacity for organizing defence and security. In the eighties, Paloh had been among the founders of FKPPI (Forum Komunikasi Putra-Putri Purnawirawan Indonesia, Communication Forum for Sons and Daughters of Retired Army Personnel), a preman organization closely connected to the military and committing extra-legal violence on its orders. From 1984 to 1987 , Paloh was chair of the advisory council, with Pemuda Pancasila leader Yapto Soerjosoemarno as its secretary. ${ }^{10}$ Paloh's past involvement with preman was seen as mostly irrelevant by his 2013 supporters since, as one person put it: 'that was in the past, when he was young. Others saw it as an asset, for the experience would surely have taught Paloh how to run a security force while at the same time being aware of the dangers an ormas could come to pose to ordinary citizens. Moreover, this aspect of his past was considered as proof that he was a 'tough guy' who would not hesitate to take action should the National Democrats' ideals or the security of Indonesia become in jeopardy.

Globe Asia (Zainuddin 2012:46) ranked Paloh as the one hundred and second richest Indonesian in 2012, with a net worth of 220 million Us dollars. As owner of the Media Indonesia Group and Metro TV, he has a substantial vehicle to spread the party's ideas and ambitions. Paloh's assets are his relatively new arrival on the political stage, his past involvement with a violent preman organization, his limited role in the New Order, his public distancing from Golkar and his passionate and socially driven speeches. He combines several of the characteristics that made New Order patrons liked and feared at the same time; Paloh is strong, powerful, not afraid to use violence and he passionately pleas for a more social and just Indonesian society. Also, his control over television channels assists him in getting his message across, although other parties - notably Golkar - have begun enlisting other media tycoons for the same purpose. ${ }^{11}$ The formation of BARET as a security force to the National

10 See FKPPI's website at http://www.fkppi.or.id/index.php/pengurus/fkppi/periode-ke-2. Last accessed 7 July 2015.

11 Golkar chairman Aburizal Bakrie owns station tv One through his Bakrie Group, while Chairul Tanjung, the owner of Trans TV and Trans7, is a close friend of incumbent president Susilo Bambang Yudhoyono, Hary Tanoesoedibjo, the owner of PT Rajawali Citra Televisi Indonesia, Indonesia's most popular television network, and PT MNC Skyvision, the country's largest pay-tv network, accepted a position as chairman of the board of experts of Paloh's National Democrat Party in 2012, but left again after a few months due to 'internal conflicts' (Sufa 2013) and moved to Golkar. With objective representation a rising concern (see Nazeer 2012), a parliamentary commission has started work on a draft amendment to the Broadcasting Law in order to severe political-media links ahead of the 2014 presidential elections (Jakarta Post 2013). 
Democrat Party appears to have been more of a side project - an element required to complete the full spectrum of forces a powerful leader should have at his disposal - than the creation of an organization aimed at violence and intimidation.

A rather different example of the effects of violence combined with a reputation for toughness is found in the development of Pemuda Pancasila's political aspirations. Following the fall of Suharto in 1998, this organization decided to end its collaboration with Golkar on the grounds that its support for the party did not result in appropriate returns. Pemuda Pancasila declared its own party, Partai Patriot Pancasila, on Pancasila Day 2001 and was registered in August 2003. The chair, Yapto Soerjosoemarno, explained that the cadre wanted to form an independent party to be able to benefit from its own supporters and their votes (see Dewanto 2003). They expected to gain many votes from young people who would be charmed by Pemuda Pancasila's toughness, while the inclusion of well-known singers and other artists on the candidate list would attract the workers and fishermen whom the party intended to target. The party secretary ventured the estimate that, with the votes of Pemuda Pancasila's large membership included, they would obtain $5 \%$ of the national vote (Liputan6.com 2004).

In the 2004 national elections, however, Partai Patriot Pancasila obtained 1,073,139 votes, or slightly below one percent, which meant that the party failed to gain any seats in parliament (Ananta et al., 2005:22). Partai Patriot Pancasila did not manage to convince its intended electorate, possibly because of decades of doing the 'dirty work' for the freshly removed New Order regime, and the strong competition presented by parties headed by known critics of Suharto and Golkar. Due to this election result, the party had to officially dissolve before registering again and, for the 2009 national elections, it registered as Partai Patriot, losing Pancasila, perhaps because public opinion had decidedly turned against the New Order usage of the concept. Nevertheless, these results were even worse: 547,351 votes or 0.53\% (Komisi Pemilihan Umum 2009:41).

Wilson (2010:209) wondered whether the low number of votes indicated that the party had made the same mistake that Pemuda Pancasila gave as its reason for leaving Golkar: failing to accommodate and articulate the aspirations of its supporters. Pemuda Pancasila members in East Kalimantan, who had not voted for Partai Patriot, suggested two further explanations to me. A first reason lay in the distinctive 'Jakartan' or 'Javanese' character of the candidates on the list, and a second in their desire to vote strategically rather than to support a small party that would almost certainly fail to obtain sufficient mass to become of national importance. Former or still serving Pemuda Pancasila members can be found throughout Indonesia's large parties and continue to 
take the organization's interest at heart. In a 2013 interview, former Pemuda Pancasila chair and current Golkar parliamentarian Yorrys Raweyai pointed out that, of the 560 Members of Parliament, about thirty were former Pemuda Pancasila members (Munawwaroh 2013a). Interestingly, Raweyai also stressed that he considered himself stigmatized by people calling him a preman, as he felt that he had never violated the law during his years in the organization (Munawwaroh 2013b).

Raweyai's notion of Pemuda Pancasila members as law-abiding, stigmatized citizens contrasts with the findings of a September 2013 report of a Pemuda Pancasila attack on a court of law dealing with a land dispute:

Hundreds of members of an organization notorious for its thuggery attacked the Depok District Court in West Java on Tuesday morning, threatening the chairman of the court over a disputed land case. Members of Pemuda Pancasila, dressed in the organization's military-style uniforms, rammed motorbikes into the court's glass entry door, smashing their way into the building as they headed to chairman Prim Haryadi's office. 'At about 8:30a.m., I was receiving some guests [in my office], when all of a sudden hundreds of PP members came breaking into the building with motorbikes,' Prim said later on Tuesday.

Upon noticing the chaos on CСTV, the judge immediately dismissed his guests just as dozens of angry PP members broke the door and windows in his office. The group reportedly launched a chair in Prim's direction in addition to threatening to kill him over a court decision to delay the execution of a previous verdict. 'They just came in, more than 10 people were in my room wearing PP uniforms, including the leader, Rudi Samin, who refused to accept the court's decision to postpone a land eviction order. They threatened to kill me,' he said'.

JAKARTA GLOBE 2013

According to the article, the group came to the court house on behalf of Rudi Samin, the local Pemuda Pancasila leader, who had recently won a dispute over thirty-three hectares of land and had been informed by the court that the verdict would be executed on 17 September. Yet as the opposing party had filed an appeal, the court was held to stall the execution until after the appeal would be heard. In the attack on the seventeenth, the chairman of the court was forced to immediately sign the verdict, thereby allowing the eviction to commence. Rudi Samin confirmed the attack and took responsibility for the damage done to the building. Samin stated: 
'If the court would like to report us to the police, then go ahead. Pemuda Pancasila will take responsibility, he said. Explaining their motive behind the violence, Rudi said the attacks had been conducted to express their disappointment and distrust of the court. The PP would like to teach the district court a lesson. 'This is how you implement the law,' Rudi said.

JAKARTA GLOBE 2013

Samin, and two of his helpers, were arrested for vandalizing state property and transferred to regional police headquarters in Jakarta. As the case was examined further, various inconsistencies started to come to the fore. The first was that Samin was continuing legal procedures on behalf of other claimants who had never given him permission to act as their representative or put the claim in his name. The other claimants maintained that Samin owned about one and a half hectares of the contested land (which he inherited from his parents), and that the rest belonged to a group of some one and a half thousand other people (Virdhani 2013). The one reason they dared to speak up, a spokesperson stated, was because of Samin's removal by the police. Samin's urgency in getting the verdict executed, as a legal scholar following the case explained to me, was that the continuation of procedures would make both the appeal and the objections of the other claimants much harder for the judiciary to address.

Samin's detention was short-lived and does not appear to have resulted in further charges. In Depok's Pemuda Pancasila 2014 meeting, he emphasized that members should not fear arrest or, if they did, should not become Pemuda Pancasila members. Arrests are part of the process of Pemuda Pancasila activities, he felt, and he pointed out that he himself had been detained twice since he started his term as Depok's Pemuda Pancasila leader (Maulana 2014). At the time of writing, Samin was running in the 2014 general elections as a parliamentary candidate for the Indonesian Justice and Unity Party (PKPI), a split-off from Golkar which so far has failed to make the electoral threshold for national parliament.

Yet, in other contexts, Pemuda Pancasila is appreciated and liked by the population at large. A striking example is the discussion instigated by the 2012 movie The Act of Killing, directed by Joshua Oppenheimer, which sees aged Pemuda Pancasila members in Medan re-enact the killings of communists that were carried out in 1965 . Indonesian history depicts this killing of hundreds of thousands to millions of people nationwide as an act that saved the country from a communist coup, and declares those who carried them out as nationalists or even heroes. The film provides a much more critical picture and asks how the killings benefitted those in power, whether those killed were indeed guilty and who, in the end, actually profited from the killings. While the film 
provided intellectuals and activists with a platform to debate the killings as genocide and a human rights crime, others argue that the film is a foreignproduced narrative intended to tar Indonesia's reputation (e.g. Arham 2014) and presents a caricatured and one-sided view of events (Maullana 2014). The movie seems unlikely to bring about a new perspective on Pemuda Pancasila among the Indonesian population at large, and may even inadvertedly become a vehicle rallying support for the group's past acts.

Less bloody is the present day position of the organization in the East Kalimantese business town of Balikpapan. Here Pemuda Pancasila is headed by Syahrir Taher, a man in his sixties, who has been a Pemuda Pancasila member for decades. Locally, he is known as Pak Ketua ('Mr chairman') as he is the chairman of the local Pemuda Pancasila chapter, the chairman of the Partai Patriot faction in Balikpapan's parliament, and the chairman of Persiba, Balikpapan's football club. In a series of interviews in 2013, he told me how, in the fifties, his parents had migrated to Balikpapan from Makassar and brought him along as a little boy. He had little opportunity to go to school, but worked in the market and the harbour: first as a porter and wage labourer, and later as a provider of security. In that position, he had to fight and sometimes stab people, for which he went to jail a few times. He had no choice, he felt. He had agreed to guard his clients' properties, and had he run off, his reputation as a trustworthy guard would be gone. His violence and consequent prison sentences established his credentials as a tough guy who would not back down from his given word and was not afraid to draw blood or spill his own. There were other positives, too: he worked his way up from sleeping under market stalls to being able to buy his first house.

Contrary to Raweyai, Taher readily agreed that he is a preman and is happy to be known as such. As a member, and later a leader in Pemuda Pancasila, he put a lot of emphasis on helping his fellow members whenever needed. He was able to start a construction business, which flourished because of his ability to obtain government projects through his connections, and he became an affluent citizen. Taher used his funds to send his children to study overseas (religion in Bagdad before the invasion of Iraq and business studies in New Zealand afterwards), as well as for sponsoring Persiba, which, thanks to his support, sports at least three foreign players in the team each season. Taher is famous throughout East Kalimantan for his lavish handouts of food, favours and funds during the breaking of the fast each evening of Ramadan, at which time hundreds flock to his house, barring the traffic in the street (see Alamijaya 2013 for an on-site report). He takes great pride in helping anyone who requests his help and has a reputation for being generous. Yet, he is also known for asking people who request his assistance for a second time, what they have 
done to improve their position themselves. And this is, according to several market labourers with whom I discussed Taher's generosity, quite embarrassing. It makes people think twice before they knock again on Taher's door and ask for help.

Pemuda Pancasila and Taher are well established in the city. Taher maintains that the organization saved his life because he used to lack discipline when he joined. If Pemuda Pancasila had not taught him to think first and control his temper, he believes that he would have been long dead, stabbed or cut up by a rival in the protection business. Through his position in city parliament, Taher is involved in much of the city government's contracting, through which Pemuda Pancasila obtained numerous security contracts, including building projects, mining operations, employee housing areas, shopping centres and parts of the port. Pemuda Pancasila maintains a cordial relationship with East Kalimantan's police and army commanders, which ensures that major security deals are divided among these three groups.

As the chairman of soccer club Persiba, Taher is popular among Balikpapan's soccer enthusiasts. He arranges that the team gets good equipment, substantial sponsor deals and a steady stream of international players. In this position, he also holds an important role in the local election campaigns, as candidates vie for fifteen minutes of speaking time to address the audience ahead of a Persiba home match. Taher's control over this opportunity makes him highly influential in local politics.

Finally, Taher is a respected member of Balikpapan's Bugis community, after the Javanese the largest ethnic group of the city and one that is well-organized through the Kerukunan Keluarga Sulawesi Selatan (Harmonious Family of South Sulawesi, KKSS) - an organization that unites, connects and organizes the Bugis and Makassarese groups in the city. As Bugis are a major group of Pemuda Pancasila's members, there is a certain amount of overlap between the two organizations. In Balikpapan, Pemuda Pancasila have steadily retracted from the street work of security provision, rent-seeking and the parking business. Part of the more criminal elements of this business - gambling, prostitution, alcohol and drug smuggling - are now controlled by young preman who pay fees to Pemuda Pancasila through the Kkss (if they are Bugis) or other street groups. This way, Pemuda Pancasila is able to disassociate itself from criminal activities to a certain degree. But it is generally known that the organization does have considerable influence in the city and control over events, not in the least because of their links with preman.

An illustration of this control is the 2011 conflict over the Bugis ormas La Galigo. A group of Bugis, from within KKss and led by city parliamentarian Dahrimama, intended to set up their own ormas, which would go by the name 
of La Galigo, after the famous Buginese epic poem of that name. As preparations for the official procedure were under way, indigenous Dayak, Banjar, Kutai and other Kalimantese organizations called upon the city government to prohibit the establishment of the organization as it was foreign to Kalimantan soil and would no doubt lead to ethnic tensions. As both sides hardened their stances and pro and contra demonstrations were taking place, the police command decided to set up road blocks around city parliament and bring in extra squads of armed mobile police (brimob), which gave the usually peaceful city the look of a place awaiting invasion. After several days, in which leaders of both sides engaged in discussions with the police and city government, Pemuda Pancasila announced that they would not tolerate La Galigo, as they considered the organization disruptive to the peace of the city. The indigenous protesters were surprised and relieved, as they had expected Taher to side with his fellow Sulawesians. The La Galigo faction was disappointed, but took their loss as the Bugis in Pemuda Pancasila convinced the Kkss to end their support to the initiative. Very few media reported on the La Galigo issue and the ensuing tensions, and none mentioned Pemuda Pancasila or Taher, but as the police cleared away the road blocks, Pemuda Pancasila flags were flying from poles in the middle of the road in front of the city hall.

The actions by the groups discussed in this paragraph and the manner in which they present themselves indicate the importance attached to public opinion, albeit in a variety of ways. The docile attitude of the National Democrats' BARET is interpreted as proof of Surya Paloh's serious intentions. It is felt that he has a strong control over the organization. BARET is seen more as an aid organization which provides assistance in case of emergencies than as a band of thugs instrumental in building a shady protection-racket empire at the cost of the population. Many Indonesians I spoke to saw BARET as a 'good' ormas geared towards defending the peace and order within the nation. Moreover, they considered Paloh's ability to control BARET as proof of his suitability for the position of national leader.

The various examples drawn from Pemuda Pancasila's recent history show similar attention for the role of powerful individuals in society. Although the organization may have been unable to establish itself as a political party on the national level, its influence on the local level is not to be ignored. The aspects of the case of Rudi Samin in Bogor are striking. First, the fact that the media reports displayed shock over the attack on the district court, and that they offered considerable space to the villagers opposing Rudy's claim. Second, the proud and unrepentant attitude of Samin: the 'true mark of a real preman', a Balikpapan Pemuda Pancasila member assured me. 'He stands for what he believes is right. If he sees that justice is not being served by a court of law, that 
court needs to be taught a lesson.' This Pemuda Pancasila member felt that the outcome of the case was not necessarily bad for Samin: he might have had to spend some time in prison, but he had shown his dedication and toughness, thereby stressing his reputation as a powerful leader who is not afraid to act for cases he considers as good, regardless of the consequences.

Syahrir Taher in Balikpapan is an example of the type of 'self-made man' Rudi Samin likely aspires to become. Taher's own violent activities lie in the past and served him to steadily move into more respectable businesses. Making his fortune there, he has since added friendliness, helpfulness, piety and generosity to his reputation for toughness. As a result, he is widely liked and appreciated among the city's population. A Balikpapan lawyer who was a mutual acquaintance of Taher and me and present at my first meeting with Taher, told me afterwards:

He always explains his nickname of 'Pak Ketua' as referring to his various chairmanships, but that is not precisely what it means. What it means is that he is the chairman of Balikpapan. He runs everything; nothing big happens here if he does not support it. No business deals.... Candidates for the mayoralty are not accepted as candidates if he does not approve of them.

\section{A Need for Ormas? Brigade Manguni as a Case for Success}

Suharto's unexpected resignation in 1998 was accompanied by a number of local wars in various parts of Indonesia (see Van Klinken 2007). In 1999, fighting broke out between Christians and Muslims in the Moluccas. As the Muslim side began receiving support from the mainly Javanese Laskar Jihad militia, Christian refugees started to arrive in the Minahasa, the northernmost tip of Sulawesi and a predominantly Christian area. They brought with them news that Laskar Jihad fighters intended to follow the refugees into the Minahasa. A number of local militias were then set up to prepare for the defence of the area (see Jacobsen 2004; Henley, Schouten and Ulaen 2007). Among these was a group called Brigade Manguni; the name was taken from one of the fighter groups that held out the longest against the Indonesian army during the Permesta Rebellion of $1958-1961 .^{12}$ Like their illustrious predecessors they

12 Permesta was an uprising in parts of Sulawesi and Sumatra in the 1950s against Javanese domination of the governance of the Republic and Jakartan control over the development of these non-Javanese areas. 
prepared themselves through physical training and were taught indigenous magic by the tonaas, the leaders of the movement. These leaders also managed to obtain arms though contacts in government, the army and the police. Brigade Manguni's main leader was (and still is at the time of writing) Dicky Maengkom, a Manadonese who had returned a few years earlier from Jakarta where he had made a career as preman and entrepreneur. With the reputation, experience and contacts to form a militia, Maengkom set up a collaboration with the regional government, the church and local preman which resulted in a large, well-connected organization with a clear command structure and chapters throughout the area. Specific groups within Brigade Manguni received training from the military so that they could act as irregular auxiliaries to the army and police.

Laskar Jihad chose to travel to Poso in Central Sulawesi rather than to the Minahasa, probably because the Minahasan Muslims refused to side with Laskar Jihad and because a Muslim-Christian conflict was already brewing in Poso. In turn, Brigade Manguni also sent groups of fighters south, where they operated under the name of Kelalawar Hitam (black bats) because they were dressed fully in black and allegedly could fly noiselessly though the night using Minahasa magic. As national forces began to step in to bring the conflict to a close, Laskar Jihad and the Kelalawar Hitam left the area. Laskar Jihad was dissolved, while Kelalawar Hitam members retook their places as Brigade Manguni members and added considerably to the organization's prestige. With peace setting in in Sulawesi, Brigade Manguni began to place more emphasis on securing Minahasan society against more a variety of threats and providing a wider range of services. 'We are like Linmas (Lingkungan Masyarakat, a government service set up to respond to emergencies), only bigger and ready to deal with all kinds of danger. We can respond better', a Brigade Manguni tonaas explained. In practice, this means that Brigade members guard strategic public locations in the area during important occasions - such as elections, festive days, crisis meetings and so on. Also, they assist the government in case of natural disasters, such as volcanic eruptions or floods, by looking after their own members and their families. As with Pemuda Pancasila, Brigade Manguni recruited local heavies into the organization to secure the streets by employing them in their security business or the construction operations ran by its leadership..$^{13}$

The organization continues to emphasize its relevance by reacting to any potential threat to the integrity and peace of the Minahasa and its Christian

13 According to Maengkom, the Newmont Mining Corporation, which ran a gold mine in the Minahasa between 1993 and 2005, was one of their first major customers. 
inhabitants and by announcing mobilizations and preparing its fighters. Recent major cases include an attempt by Front Pembela Islam (the Islamic Defenders Front, a militant Islamic ormas) to open a chapter in the town of Bitung in 2009, and the 2013 invasion of the Malaysian state of Sabah by several hundred armed fighters from a militia who intended to claim the land for the former Philippine Sultanate of Sulu. Brigade Manguni used these occasions to emphasize the need for civilians to come to the aid of the army and police in guarding the Minahasa from outside threats. Thus, the organization regularly displays its level of organization and its potential for coordinated action. During official public occasions and national celebrations, the organization takes part in parades and provides honorary guards, therefore also emphasizing its connection to the state. Its leaders give speeches and muscled and tattooed members engage in displays of feats of invulnerability magic.

As Minahasans have migrated and settled throughout Indonesia, local chapters of Brigade Manguni have been established in locations like East Kalimantan, Jakarta, Bali and Makassar. These chapters are too small to pose competition to the local ormas, but the mother organization is respected and guarantees Brigade Manguni a (advisory) voice in local affairs of importance. More importantly, the Brigade Manguni network connects Minahasan politicians, entrepreneurs, professionals and heavies throughout Indonesia. Local chapters act as 'embassies', representing the Minahasan community at large and making sure that relevant information reaches interested parties. As such, Brigade Manguni has increasingly become a brokerage network connecting Minahasans throughout Indonesia as well as Minahasan and Indonesian businesses. It provides local knowledge, personnel, security or other services in every town or city where the organization is represented by a chapter. In 2010, Brigade Manguni was registered as a national organization by the Ministry of the Interior and, since then, this brokering of knowledge and business has increasingly expanded. This had brought the organization increasingly into contact with business people and politicians, and the leaders of the regional chapters are generally on good terms with the local power holders, and able to negotiate their interests through diplomacy rather than threats.

An example of this is the 2012 refusal of the population of Balikpapan to let Front Pembela Islam establish a chapter in this city. This, in itself, was an unlikely outcome because the majority of the city's population is Muslim and had no particular reason to object to the arrival of this ormas in their home town. The city has a minority Christian population which is mostly associated with indigenous groups. As they had just managed to prevent the large Bugis population - who are generally Muslim - from founding the La Galigo ormas in 2011 (see above), there was little reason to expect the Bugis to step out and 
join their adversaries in objecting to the arrival of Front Pembela Islam. However, they did so nevertheless - KKss representatives joined the protests and signed the petition asking city government to prevent the establishment of a Front Pembela Islam chapter in the city. When I spoke to the kKss regarding this choice, they told me that they had consulted with the head of the local Brigade Manguni chapter, with whom they maintain an 'all-Sulawesi' interest forum. The Brigade Manguni tonaas for East Kalimantan pointed out that those actively arguing for a Front Pembela Islam chapter were mostly Javanese, which would likely limit the chance of solid Sulawesi influence in the chapter. Also, he suggested, it was highly likely that Front Pembela Islam would upset the current power balance and instigate protests and riots to establish itself, which was bad for everybody's business. He also told the Kkss that the Christians who had objected to La Galigo were otherwise more than happy to work and live with the Bugis, and had no intention of further protests or violence. The possibility of Front Pembela Islam coming to the city had established ormas close ranks due to mediation of the local Brigade Manguni contingent, for which the latter duly took the credit.

Brigade Manguni evolved from a regional ormas established to protect the Minahasa against immediate threats into a nationwide network geared towards regional business opportunities and political influence. The Brigade still relies on popular support as well as on contacts with regional power holders, but its expansion into the national arena has made it into an organization for which trustworthiness has become more important and non-state violence less important. Its role as a social, unifying organization aimed at providing security for its members and the Minahasa does, however, remain crucial. In January 2014, parts of the Minahasa were hit by serious flooding. This caused the nearby East Kalimantan chapter to start sending over increasing amounts of goods, personnel and money to assist in disaster relief. The willingness to allocate considerable resources to such actions illustrates local chapters' willingness to operate beyond their local affairs and take the continued provision of Minahasans' security as a serious task.

\section{Conclusion}

Non-state provision of local security and defence of the state are inherent parts of Indonesian history and state - society relations. Armed civilians fought the Dutch for independence before the Indonesian army came into existence and continued to provide security among their local communities afterwards. Respondents cited above argued that once the values of Pancasila became 
known, these local groups accepted that philosophy and helped to establish the national state. But the New Order regime, they maintained, appropriated both ormas and Pancasila to serve its own needs. This caused public perceptions of both to deteriorate, but Reformasi would not have succeeded if new, local non-state security groups had not been mobilized to maintain order. While there are indeed examples of ormas stepping up in local social crises and calming matters down (see Bakker 2015), this 'local hero' image screens the fact that these ormas, rather than being passive guardians, are agents capable of generating considerable local influence. This influence is manifested in overt relations with politicians based on the support ormas can mobilize for their campaigns and elections, in the number and value of the project contracts that ormas leaders are able to obtain, and in the enlisting and subsequent employment of local preman muscle in security operations controlled by the organization. Importantly, however, an ormas' success depends on its appreciation by society. Without members and supporters to come out and back up the ormas in public, they will fail to impress anyone.

Ormas' provision of local security, considered a task of the state as the holder of the monopoly on legitimate violence in most theories of state-building, generates much support. However, their activities are also illustrative of an important aspect of citizen-state relations for, as civil society watchdogs and ormas alike point out, what guarantees the fairness and legitimacy of government institutions after so many examples of corruption, nepotism and other illegal actions damaging the interests of the population? As with Weber's observation, which notes that cities rose once they disposed of the soldiers to keep the overlord knights out of the cities' market places, ormas argue that they protect citizens' interests in the face of an elite that will not give up its New Order privileges. In other words, furthering the development of citizenship through active support of the needs and rights of the population is a route for ormas to ensure themselves of beking by society: a patron that cannot be voted out of office, but whose support ensures ormas' access to politicians and the economy.

Nevertheless, ormas remain popularly associated with criminal activities, a disregard for the law and a willingness to use violence. While this is a powerful and fear-inspiring image to capitalize upon, the application of violence and involvement in crime requires nuance and consideration if societal support is to be secured. Ormas' actions may involve violence and be illegal according to national law, but they will only negatively impact the ormas' reputation if a sizeable part of society perceives them as unjust or criminal. 'If we do not threaten to use violence, or actually use it every once in a while, we would be nothing but another NGO. Government does not listen to those organizations 
and the people do not know them', stressed Fary Malunda of Brigade Manguni. Yet, such violence and crime is subject to moral scrutiny. While few ormas supporters seem bothered by their defenders' involvement in such illegal activities as racketeering, gambling or prostitution, and even consider ormas' influence as proof of its power and authority, involvement in drug trade, kidnapping or contract murder meet with considerably less societal indifference. That is why most ormas deny any involvement in these criminal activities.

Ormas' activities as well as leadership are a mixture of populism, pragmatism and personal interests, and concern societal interests as well as reactionary patrimonialism. Leaders must seem strong, just, fearless and charismatic in order to be deemed capable. In this light, the action of Rudi Samin of Pemuda Pancasila, discussed above, makes sense: it is not just sheer brutality to ride a motorbike into the district court; it is a statement of courage and power which states that he is not going to back down when faced with what he perceives to be an injustice.

Ormas in Indonesia today exist by using a repertoire of citizens' rights and societal needs combined with the imagery and techniques that organizations like Pemuda Pancasila developed during the New Order. This image is powerful, but seems unable to survive the translation from the private loyalty of patronage to the public justification of one's actions required by democracy. Partai Patriot's political defeat and the steady decrease in prominence of political parties' security forces as violent actors, such as the National Democrats' BARET down-tuning to mere vote mobilizers, illustrate this. The practice of mobilizing societal support in order to put pressure on government signifies, to a certain extent, a reversal of patronage structures that confirms the rising influence of citizens aspired by democracy. As long as Indonesia's bureaucracy does not manage to inspire the sort of trust in government that will make support for ormas redundant, this combination of societal championing with elements of reform, patronage and crime creates a form of citizenship that emphasizes the position of the individual within the local community rather than within the nation.

\section{References}

Abrams, P. (1988). Notes on the difficulty of studying the state. Journal of Historical Sociology, $,(1), 58-89$. doi: 10.1111/j.1467-6443.1988.tboooo4.x.

Aditya, W, (2012). Mari Bung Rebut Kembali! Surya Paloh [2010-2012]. Jakarta: MI Publishing. 
Alamijaya, J. (2013, 28 July). Ratusan Warga Tumpah Ruah di Acara Buka Puasa Syahril HM Taher. Tribunnews.com. http://www.tribunnews.com/regional/2013/o7/28/ ratusan-warga-tumpah-ruah-di-acara-buka-puasa-syahril-hm-taher.

Ananta, A., Ariffin, E.N., \& Suryadinata, L. (2005) Emerging Democracy in Indonesia. Singapore: Institute of Southeast Asian Studies.

Arham, F. (2014, 25 January). Film "The Act of Killing", Titik Nol, Sejarah SBY. www .kompasiana.com. Retrieved from http://www.kompasiana.com/prontzthetounz/ film-the-act-of-killing-titik-nol-sejarah-sby_5529850c6ea8347266552d15.

Aspinall, E. (2013). A Nation in Fragments. Patronage and Neoliberalism in Contemporary Indonesia. Critical Asian Studies 45 (1), 27-54. doi: 10.1080/14672715.2013.758820.

Aspinall, E., \& Fealy, G. (eds) (2003). Local Power and Politics in Indonesia. Decentralisation and Democratisation. Singapore: Institute of Southeast Asian Studies.

Aspinall, E., \& Mietzner, M. (eds) (2010). Problems of Democratisation in Indonesia. Elections, Institutions and Society. Singapore: Institute of Southeast Asian Studies.

Bakker, L. (2009). Adat, Land and Popular Democracy. Dayak politics in East Kalimantan. Borneo Research Bulletin 40, 202-220.

Bakker, L. (2015). Illegality for the General Good? Vigilantism and Social Responsibility in Contemporary Indonesia. Critique of Anthropology 35 (1), 78-93. doi: 10.1177/0308275X14557092.

Bakker, L. (2016). Organized violence and the state. Evolving vigilantism in Indonesia. Bijdragen tot de Taal-, Land-, en Volkenkunde. 172(2-3), 249-277.

Barbalet, J. (2010). Citizenship in Max Weber. Journal of Classical Sociology 10 (3), 201-216. doi: 10.1177/1468795X10371717.

Barker, J. (1998). State of Fear: Controlling the Criminal Contagion in Suharto's New Order' Indonesia 66, 7-42.

Barker, J. (1999). Surveillance and Territoriality in Bandung. In V.L. Rafael (ed.), Figures of Criminality in Indonesia, the Philippines and Colonial Vietnam. Ithaca (pp. 95-127). New York, NY: Cornell Southeast Asia Program.

Berenschot, W., Schulte Nordholt, H. \& Bakker, L. (2017) Citizenship and Democratization in Postcolonial Southeast Asia. In: W. Berenschot, H. Schulte Nordholt, \& L. Bakker (Eds.) Citizenship and Democratization in Southeast Asia (pp. 1-32). Leiden: Brill Publishers.

Chandra, K. (2004). Why ethnic parties succeed: patronage and ethnic head counts in India, Cambridge [etc.]: Cambridge University Press.

Dewanto, A. (2003, 1 August). Kecewa pada Golkar, Pemuda Pancasila Bikin Partai. Kompas. Retrieved from http://tempo.co.id/hg/nasional/2003/o8/o1/brk,20030801 -o6,id.html.

Jacobsen, M. (2004). Factionalism and secession in North Sulawesi Province, Indonesia. Asian Journal of Political Science 12 (1), 65-94. doi: 10.1080/02185370408434234. 
Jakarta Globe (2013, 18 September). Court Wilts Under Attack From Pemuda Pancasila Thugs. Jakarta Globe. Retrieved from http://jakartaglobe.beritasatu.com/news/ court-wilts-under-attack-from-pemuda-pancasila-thugs/.

Jakarta Post (2013, 25 September). Indonesian House Moves to Break Political-Media Links. Jakarta Post. Retrieved from http://www.nationmultimedia.com/aec/Indo nesian-House-moves-to-break-political-media-li-30215582.html.

Henley, D., Schouten, M., \& Ulaen, A. (2007). Preserving the peace in post-New Order Minahasa. In H. Schulte Nordholt \& G. van Klinken (eds.) Renegotiating Boundaries. Local politics in post-Suharto Indonesia (pp. 307-326). Leiden: KITLV Press.

Kingsbury, D. \& Aveling, H. (2003). Autonomy and Disintegration in Indonesia. London/ New York: RoutledgeCurzon.

Komisi Pemiluhan Umum (2009). Buku Saku Pemilu 20og. Jakarta: Komisi Pemiluhan Umum.

Kristiansen, S. \& Trijono, L. (2005) Authority and Law Enforcement: Local Government Reforms and Security Systems in Indonesia' Contemporary Southeast Asia 27 (2), $236-654$.

Liputan6.com (2004, 8 March). Partai Patriot Pancasila Menargetkan Lima Persen Suara. Liputan6.com. Retrieved from http://news.liputan6.com/read/73728/ partai-patriot-pancasila-menargetkan-lima-persen-suara.

Lund, C. \& Boone, C. (2013). Introduction: Land Politics in Africa - Constituting Authority over Territory, Propery and Persons. Africa 83 (1), 1-13. doi: http://dx.doi .org/10.1017/Sooo197201200068X.

Margianto, H. (2011, 7 September). Surya Paloh Mundur Dari Golkar. Kompas. Retrieved from http://nasional.kompas.com/read/2011/og/o7/14493094/Surya.Paloh. Mundur. dari.GolkarMedia Indonesia (2012). Nasional Demokrat Ajak Jaga Kemurnian Pancasila. 4 June.

Maulana, H. (2014, 5 March). Pemuda Pancasila Depok Gelar Raker Cabang ke-5. 5 March. Depoknews.com. Retrieved from http://www.depoknews.id/pemuda -pancasila-depok-gelar-raker-cabang-ke-5/.

Maullana, I. (2014, 18 February). "The Act of Killing" Masuk Oscar 2014, Jay Subiyakto Kecewa. Kompas. Retrieved from http://entertainment.kompas.com/ $\mathrm{read} / 2014 / 02 / 18 / 1238173 /$. The.Act.of.Killing.Masuk.Oscar.2014.Jay.Subiyakto .Kecewa.

Metrotvnews.com (2013, August 2013). NasDem Jatim Siapkan Barisan Reaksi Cepat. Metrotvnews.com. Retrieved from http://news.metrotvnews.com/read/2013/08/15/ 175152/NasDem-Jatim-Siapkan-Barisan-Reaksi-Cepat.

Munawwaroh (2013a, 17 March) Alumni Pemuda Pancasila Jadi Menteri dan Politikus. Tempo. Retrieved from http://metro.tempo.co/read/news/2013/03/17/064467526/ alumni-pemuda-pancasila-jadi-menteri-dan-politikus. 
Munawwaroh (2013b, 17 March) Yorrys Raweyai Tak Sungkan Disebut Mantan Preman. Tempo. Retrieved from http://metro.tempo.co/read/news/2013/03/17/064467507/ yorrys-raweyai-tak-sungkan-disebut-mantan-preman.

Nazeer, Z. (2012, 10 March). Indonesia's Political Media Masters. Jakarta Globe. Retrieved from http://jakartaglobe.beritasatu.com/archive/indonesias-political-media -masters/.

Nugroho, E. (2013). Bill on Societal Organizations (RUU Ormas) and Freedom of Association in Indonesia. International Journal of Not-for-Profit Law 15 (1), 13-37.

Olivier de Sardan, J.P. (2005). Anthropology and Development: Understanding Contemporary Social Change. London: Zed Books.

Robison, R. \& Hadiz, V. (2004) Reorganising Power in Indonesia. The Politics of Oligarchy in an Age of Markets. London and New York: RoutledgeCurzon.

Rosarians, F. (2013, 2 December) Ini Alasan Surya Paloh Hengkang Dari Golkar. Tempo. Retrieved from http://nasional.tempo.co/read/news/2013/12/02/078533852/ ini-alasan-surya-paloh-hengkang-dari-golkar.

Ryter, L. (1998). Pemuda Pancasila: The Last Loyalist Free Men of Suharto's Order? Indonesia 66, 44-73.

Sakai, M. (2002). Beyond Jakarta, Regional Autonomy and Local Societies in Indonesia. Adelaide: Crawford House Publishing.

Schulte Nordholt, H. (1991). The Jago in the Shadow: Crime and 'Order' in the Colonial State in Java. RIMA: Review of Indonesian and Malaysian Affairs: a semi-annual survey of political, economic, social and cultural aspects of Indonesia and Malaysia, 25(1), 74-91.

Schulte Nordholt, H. (2014). From contest state to Patronage democracy: The longue durée of clientelism in Indonesia. In D. Henley \& H. Schulte Nordholt (Eds.) Environment, Trade and Society in Southeast Asia. A Longue Durée Perspective (pp. 166-180). Leiden: Brill Publishers.

Schulte Nordholt, H. \& Van Klinken, G. (Eds.) (2007). Renegotiating Boundaries. Local Politics in Post-Suharto Indonesia. KILTV Publishers: Leiden.

Siegel, J. (1986). Solo in the New order. Language and Hierarchy in an Indonesian City. Princeton University Press: Princeton.

Sufa, I. (2013, 21 January) Harry Tanoe mundur dari NasDem. Tempo. Retrieved from http://nasional.tempo.co/read/news/2013/01/21/078455801/harry-tanoe-mundur -dari-nasdem.

Van Klinken, G. (2007). Communal violence and democratization in Indonesia; small town wars, London: Routledge.

Van Klinken, G. (2009) Patronage democracy in provincial Indonesia. In O. Törnquist, N. Webster \& K. Stokke (Eds.) Rethinking Popular Representation (pp. 141-159). Basingstoke: Palgrave Macmillan. 
Van der Kroef, J. (1985). Petrus: Patterns of Prophylactic Murder in Indonesia. Asian Survey $25,745^{-759}$.

Virdhani, M. (2013, 23 September) Perusakan PN Depok, Pepabri protes Rudi Samin Cs. Sinonews.com. Retrieved from http://metro.sindonews.com $/ \mathrm{read} / 786170 / 31 /$ perusakan-pn-depok-pepabri-protes-rudi-samin-cs-1379905599.

Wahyudi, A. (2006). Ideologi Pancasila: Doktrin yang Komprehensif atau Konsepsi Politis. Jurnal Filsafat 16 (1), 94-115.

Ward, K. (2010). Soeharto's Javanese Pancasila. In E. Aspinall, \& G. Fealy (Eds.) Soeharto's New Order and Its Legacy: Essays in Honour of Harold Crouch (pp. 27-38) Canberra: ANU E Press.

Wilson, I. (2006). Continuity and Change. The Changing Contours of Organized Violence in Post-New Order Indonesia. Critical Asian Studies 38(2): 265-297. doi: 10.1080/14672710600671244.

Wilson, I. (2010). The Rise and Fall of Political Gangsters in Indonesian Democracy. In: E. Aspinall \& M. Mietzner (Eds.), Problems of Democratisation in Indonesia. Elections, Institutions and Society (pp. 199-218). Institute of Southeast Asian Studies: Singapore.

Zainuddin, S. (2012). Masters of the universe. Globe Asia 6(6), 40-47. 


\title{
Custom and Citizenship in the Philippine Uplands
}

\author{
Oona Paredes
}

Ethnic minorities tend to have a contentious relationship with state institutions and the national majorities the state in effect represents. 'Indigenous peoples' - the global political term for 'tribal' peoples and other comparable sub-regional minorities (hereafter IP's) - are often specifically excluded or otherwise marginalized in their home countries. ${ }^{1}$ In Southeast Asia and elsewhere, 'tribal' IP's are typically regarded as the weakest link in the nation's socio-economic advancement, especially where their cultural distinctiveness is explained in nationalist discourse as primitivity or backwardness (Brosius 2003). Even when their legal citizenship is acknowledged, as ethnic minorities they are never sufficiently 'citizenly' in the eyes of the national majorities that control the state. ${ }^{2}$ As such, it is common to find the concerns of IP's ignored routinely, and their citizenship delegitimized, ultimately driving them to contest the state's cultural hegemony in the context of what anthropologist Peter Brosius (2003:121) has called 'a politics of desperation'. It is a condition of political and cultural exclusion that structures significantly the way IP's experience 'democracy', and how they understand, as well as practice, their own citizenship.

The Philippines is no exception, where the exclusion of its IP's is implicit in its current historiography, and reiterated in the structure of its government. The notion of the 'Filipino' as citizen monosubject is explicit in nationalist discourse, where the majority is Hispanized and Catholicized, whilst tribal minorities are stereotyped as living fossils of pre-colonial culture, and on some level regarded as racially inferior and mentally deficient. ${ }^{3}$ Reinforcing their exclusion from mainstream society, IP's are administered separately - a setup that, while originally intended to protect this vulnerable population, has

1 'Indigenous peoples' is used here as a political rather than cultural designation. Despite the presence of IP's throughout Southeast Asia, technically speaking most of its people, even the ethnic majorities, are indigenous to the region. While there are many local terms for a country's indigenous 'tribal' minorities, the Philippine government uses the English term 'indigenous peoples' to refer to this population officially. I follow this usage here, shortened to 'IP', which is now the common practice in the Philippines, even among the IP's themselves.

2 Here I draw on the concept of 'graduated citizenship', as discussed in McCargo (2011).

3 I have addressed this topic extensively in previous work. See Paredes (2000), and Paredes (2013), especially pages $7-9$ for the latter. 
become a hurdle to the exercise of their citizenship rights. IP's may be recognized formally as Filipino citizens today, but in the majority of the population, informal notions of citizenship continue to privilege a homogenized, Catholic 'national' monoculture to which IP's and other minorities are, at best, quaint addenda.

If the fundamental paradox of the region's democratization may be the survival of unequal patron - client relationships, the situation of IP's goes one step further. In the case of Philippine IP's, their attempted 'empowerment' through participatory democracy seems to further entrench their political exclusion and increase their risk of exploitation, as their continued administrative separation complicates governance and propels IP's into unequal, clientelistic relationships with often predatory outsiders in order to accomplish even the most basic bureaucratic tasks. At the same time, in their attempts to exercise their citizenship, IP's face overwhelming pressure to conform to mainstream Filipino culture at the expense of the very cultural traditions they are fighting to preserve. In this chapter I explore the longstanding exclusion of IP's in the region, and how it manifests itself in terms of citizenship and democratization, drawing on my ongoing research with the Higaunon of Mindanao, in the southern Philippines. ${ }^{4}$ I focus specifically on the impact of these exclusions on the experience and exercise of citizenship by Higaunons, and the long-term implications of the widening procedural and cultural gaps between their traditional political systems and the decentralized bureaucracies of the state - gaps that have developed alongside increased Higaunon political participation in the Philippine democracy.

The Higaunon case outlines some of the dilemmas of citizenship for IP's, not only in the Philippines but throughout postcolonial Southeast Asia. Given that the modern nation-states of ASEAN were built on the same colonial foundations, the status of today's IP's can be traced largely to their peripheral status

4 The material in this chapter is based on the sum of my research involving Higaunons in northern Mindanao, beginning with my MA field research in 1995 and correspondence and field visits since then, as well as regular communication with the national government agencies that administer IP affairs (OSCC and now NCIP [National Commission on Indigenous Peoples]), and workers from NGOs that have had dealings with Higaunons. The more recent information presented here is drawn from my preliminary findings in an ongoing (since 2012) field research project focused specifically on the impact of government bureaucracy on the exercise of indigenous political authority of datu and bae leaders, and another project running concurrently on oral history. The former is supported by a research grant from the National University of Singapore, and the latter by the Firebird Foundation for Anthropological Research. Due to the sensitive nature of this topic, as well as the unpredictability of local politics, I must keep my indigenous informants and other sources anonymous. 
relative to the colonial-era metropoles where conceptions of postcolonial nationhood and citizenship were originally developed and negotiated by new elites and ethnic majorities. Following Duncan McCargo (2011), citizenship has not only formal aspects (pertaining to government-recognized citizenship) but significant informal aspects (pertaining to culture) as well. With respect to its informal or 'vernacular' aspects, Renato Rosaldo (2003:1-2) points to the power of national metropoles to marginalize the ethnic minorities at their peripheries, in effect 'excluding them from full national citizenship' through the politics of difference. Coining the term 'cultural citizenship' to highlight how minorities negotiate the informal aspects of 'belonging', Rosaldo explains that citizenship is a process that takes place 'within a social field anchored in the cultural distinction between the metropolis and its hinterlands' where 'issues of citizenship become cultural' (Rosaldo 2003:3-4). Amongst the IP's of Southeast Asia in particular, ' $[t]$ he cultural question animating such dynamics focuses on how subordinated or marginalized groups define and experience their humiliation and their striving for well-being, respect, and dignity.' In the Higaunon case, we can see the active, multifaceted pursuit of fuller citizenship by individuals and communities typical of IP's. We also see how, in their desire to participate in Philippine democracy, Higaunons are transforming radically the ancestral traditions around which their ethnic identity had previously revolved.

\section{Cultural Citizenship in Mindanao}

As in most of Southeast Asia, local political history in Mindanao revolves around an ethnicized upland-lowland axis, with the island's indigenous peoples largely displaced to the interior uplands by the migration of Filipino settlers from other, over-populated regions of the Philippines - a demographic upheaval that has transformed Mindanao rapidly and radically. The indigenous peoples of Mindanao are divided into two categories: the primarily Muslim ethnic groups, collectively called the Moros, and the non-Muslim ethnic groups, collectively called the Lumad. The Lumad, in turn, are one of the two largest sub-categories of Philippine IP's (the other being the Cordillerans of northern Luzon). Among the eighteen or so Lumad ethnic groups, the Higaunon are today one of the largest, ${ }^{5}$ with multiple descent groups distributed across five provinces in northern Mindanao: Lanao del Norte, Misamis Oriental, Bukidnon, Agusan del Norte and Agusan del Sur. Their modern territory includes the

5 Estimated Higaunon population total is upwards of 250,000. 
mountain ranges that divide these provinces, and historically their economic life has revolved around forest swiddening supplemented by hunting and the collection of forest products like rattan and tree resins - and in recent decades, the individual collection of timber through 'carabao logging' 6 - for buyers in the lowlands.

Mindanao was dominated historically by a succession of Moro sultanates, to whom Lumad peoples paid tribute, but the political environment slowly changed as the region became incorporated (albeit imperfectly) into Spanish and later American colonial regimes. By the time of Philippine independence in 1946, the country was dominated by lowland-based ethnic majorities with the heavily Christianized and Hispanized cultures we recognize today as normatively 'Filipino'. Soon after World War II, these 'Christian' Filipinos colonized the southern Philippines in search of arable land. These settlers - whom the Higaunons call dumagat or 'coastal people'- now constitute an overwhelming majority, at more than seventy percent of Mindanao's population. Moro groups, down to approximately twenty percent despite consistently high birth rates, have since become the island's primary minorities. Meanwhile, the Lumad groups have diminished even more in status, being the smallest demographic minority overall (at ten percent or less of the island's population), as well as second-order minorities - basically, minoritized by another minority group - within the Moro territories. ${ }^{7}$ In the Moro-dominated areas of western Mindanao, the government's pro-settler policies (including support for armed militias) contributed directly to the outbreak of violence in the 1970s, and a sustained armed rebellion by Moros that is now manifested in the push for Moro autonomy. As second-order minorities in these Moro territories, the Lumads have been caught in the crossfire of competing factions since the beginning of the Bangsmoro rebellion in the 196os. Elsewhere in Mindanao, the 'Christian' Filipino settlers have also displaced the Lumads radically, though the Lumad response has been disorganized and largely futile in the face of land-grabbing by settlers and corporate industries, likely due to the small scale and scattered

6 This involves either the use of water buffalo or carabao to drag logs to the buyer pickup areas. However, Higaunons rarely have their own carabao and often turn to moving the heavy logs themselves by either carrying them over their shoulders or tying a rope around their waists to drag the log along. Children are also known to engage in this activity, which is called drageng in Higaunon (from the English word 'dragging').

7 The available statistics remain imprecise due to inadequate coverage in Mindanao and the fact that ethnicity is not officially reported in the national census (Montiel et al., 2012; Gaspar 2013). See Paredes (2015) for a discussion of Lumads as second-order minorities. See Barter (2015) for a broader discussion of second-order minorities in Asia. 
distribution of these communities. ${ }^{8}$ While in most Lumad communities there has been some intermarriage with the dumagat settlers, their overall political relationship remains highly contentious at the municipal and provincial level, particularly with regard to land.

The Lumads themselves recognize easily the relative privilege inherent to being born a dumagat: despite the fact that many live at or below the poverty level, membership in mainstream Filipino groups provides linguistic, cultural and religious advantages unavailable to Lumads other Philippine IP's. For one, the Philippine government bureaucracy is dominated by dumagats, and historically what the state considers 'national' interests - particularly in regard to the 'development' of Mindanao - have been synonymous with dumagat interests. Their resettlement to Mindanao, for example, was encouraged originally by loans and subsidies, infrastructure development catering to migrants' needs, and other structural support from the national government. In contrast, the IP's have faced a persistent lack of recognition from the same bureaucracies, due to a combination of racial prejudice and jurisdictional confusion, in that the national government has always administered the affairs of the indigenous minorities separately. ${ }^{9}$

Since 1997, the National Commission on Indigenous Peoples (NCIP) has been tasked with the special needs of IP's, and while there are NCIP satellite offices throughout the country, the NCIP is a national bureaucracy that is separate from the decentralized system of local governance, discussed in the next section. However, this national-level administrative apparatus for IP's has never been comprehensive, leaving out practically all the basic necessities of a normal citizen, such as healthcare, higher education, finance, taxation, entrepreneurship, transportation, social security, voting and identity papers, among others things. Instead, these basic necessities must be accessed by IP's not through the NCIP but at different levels of the local government system. Such inadequacies have driven some IP's to break out of the NCIP's bureaucratic constraints and fight for inclusion in mainstream Filipino society. But as IP's have more actively embraced and demanded their citizenship rights, they

8 See Paredes (1997). The presence of logging and mining operations in Lumad areas has long been a political and environmental problem. This is also the case for IP areas not only in Southeast Asia but also the rest of the world.

9 This administrative separation is a legacy of the American colonial period, during which the 'non-Christian tribes', including the Moros, were believed by the Americans to still be at different stages of cultural and intellectual development than mainstream Filipinos, and therefore requiring other interventions and special protection from the majority. See the article by R.J. May (2009). This history is also outlined on the website of the present-day National Commission on Indigenous Peoples at http://ncipro67.com.ph/ncip/history/. 
have had to navigate both the government bureaucracy and Filipino/dumagat culture more or less on their own. At the same time, racial prejudice against IP's remains a major barrier in their interactions with the dumagats who run these bureaucracies at all levels.

\section{Decentralization and the Higaunon Experience}

The general impact of government decentralization in the Philippines, through the establishment of the local government unit (LGU) system, has already been described by Emma Porio in Chapter 2 of this volume. With the goal of fostering greater democratization, the LGU system promotes the administrative autonomy of individual government units, from the regional and provincial levels down to the smallest government unit called a barangay. ${ }^{10}$ While this decentralized mode does foster highly localized forms of governance, as Porio's chapter shows, it ultimately reinforces economic inequalities and further entrenches the power of political elites in lowland cities and towns. The IP experience, though distinct, mirrors many of the transformations engendered by government decentralization in the lowlands. However, the IP experience is intensified politically by factors peculiar to IP communities, such as their administrative separation from 'normal' Filipinos and their liminality vis-à-vis mainstream Filipino culture and life, especially in the already peripheral Philippine south, and the resulting prejudice and discrimination they face from dumagats who regard them as inferiors. Whilst poor dumagats sometimes do have to engage in small-scale bribery to access government services, IP's suffer the greater disadvantage of not being taken seriously at all, either due to their perceived savagery and imbecility, or simply their inability to pay even small-scale bribes. However, honest and professional dumagats may also find it difficult to interface with many IP's due to linguistic issues, or the logistical barriers of dealing with remote upland communities.

Within the context of this administrative separation, however, the IP's have managed to make some legal advances, especially with regard to the recognition of their ancestral land rights. The Indigenous Peoples Rights Act of 1997 (or IPRA) modified the Spanish-era land laws that had prevented the private

10 The barangay is the smallest local government unit in the Philippines, corresponding roughly to a village or small town. Each city or municipality is made up of several barangays, depending on population size. Rural barangays generally cover larger areas, due to lower population density, whilst in a densely populated urban setting every other city block might be a separate barangay. 
titling of upland areas, where IP communities tend to be concentrated. ${ }^{11}$ Today, the national government mandates by law the integration of IP representatives within local government units in areas with a substantial IP population, but national and local government bureaucracies did not evolve in response to the needs of IP's, and any hard-won accommodations and legislative retrofits have come at a belated pace and may not be fully enforced. They have not in any way moderated the fundamental paradox of IP activism, as described by anthropologist Dorothy Hodgson (2011:6), in her study of Masaai identity politics in East Africa: 'that indigenous groups must demand recognition from the very nation-states that have historically treated them as second-class citizens (if citizens at all) by ignoring their rights, exploiting their resources, and disparaging their cultures and identities'. This is no easy feat, as they often must take extraordinary measures simply to ensure that their existing legal rights as citizens and IP's - are acknowledged by local authorities:

Demanding such recognition involves learning the relevant legal and bureaucratic categories and processes, lobbying at various levels and sites of government, appealing to popular media, seeking international support, and molding their images, identities, and agendas accordingly.

HODGSON 2011:6

In the case of Mindanao, the combination of government decentralization and racial prejudice has brought IP exclusion to the fore. Even in areas with large IP populations, local authorities tend to ignore or neglect the needs of IP's until the problem grows acute enough to have public consequences, such as when a confrontation - in which the local official faces the risk of embarrassment - is threatened or takes place. Dumagat officials, no matter how polite or courteous, are universally perceived by IP's to be indifferent to their concerns, and in some cases, disdainful and openly hostile. I have witnessed such bureaucratic malice occurring even when Higaunons come prepared with all the required identification and paperwork.

One particular case recently involved the types of incidents already familiar to researchers and advocates working with IP's. The central office of one state agency, in Manila, sent paperwork to its rural satellite office in northern

11 Full text of the IPRA law is available at http://www.gov.ph/1997/10/29/republic-act-no $-8371 /$. It is ironic that while IPRA is widely regarded as rather a belated consolation prize in light of all the IP lands that had been previously stolen, had national land laws allowed the private titling of upland areas earlier in the twentieth century, it is likely that all of these IP lands would today be owned by dumagats. 
Mindanao, certifying that a particular Higaunon community was to receive a set amount of government funding for a small economic development project. When the community inquired at the satellite office (run entirely by dumagat civil servants), the officials initially refused to respond, then later claimed to have 'lost' the hand-delivered paperwork. After a year of fruitless waiting, the community leaders, now restless, decided to propose an alternate project, only to be prevented from submitting it because the original project was apparently on the books as 'incomplete'. After the bureaucratic 'error' was cleared up with the Manila office, the Higaunons were forced to start all over again, with the satellite office requiring the Higaunons to attend new time-consuming 'orientation' meetings and pay costly new fees to produce and process the same paperwork. In order to prevent further delays, the community leaders simply did as they were told.

But it did not end there. After the final certification was once again sent down, this time from the agency's offices in both Manila and the provincial capital, community representatives went to collect their project funds, only to find that the satellite office had taken it upon themselves to assign the funds instead to a larger, neighbouring town that they felt would be better administrators for the project, possibly because the town's leader was a friend of the satellite office's manager. ${ }^{12}$ Despite their protestations and official paperwork, the community representatives were blithely ignored and told instead to take up the matter with their neighbours, with whom they have had a territorial feud ongoing since the late 199o's. Only when one of the Higaunon leaders raised the matter angrily and loudly at a public meeting attended by other agencies did the satellite officials begin to show any concern. However, it took further intervention from higher-ups in Manila and the provincial capital before the matter was fully resolved and the funds awarded to the Higaunon community that had originally proposed the project. ${ }^{13}$

Even quotidian Higaunon interactions with the dumagat-dominated state apparatus can prove to be stressful in the extreme thanks to a confluence of several factors: Higaunons' long-standing mistrust of dumagats, thanks to a

12 It was later revealed that the rival town was in no way involved in this fiasco, and that the officials at the satellite office had acted purely on their own initiative. In the immediate aftermath, the satellite office was placed under some administrative scrutiny by the provincial office, but today the same problematic dumagat officers still work there.

13 The community leaders in this case could not afford the long-distance calls, nor could they speak either English or Tagalog (Pilipino), the only bureaucratic languages of Manila. Due to bureaucratic malice, a process that should have taken less than a year lasted three years from proposal submission to actual disbursement of funds. 
century of uncontrolled land encroachment by settlers from Filipino majority ethnic groups; Higaunon ignorance of bureaucratic procedures, due in part to their illiteracy with respect to the official languages of Tagalog (Pilipino) and English; ${ }^{14}$ the already maddening opacity of Philippine government bureaucracy; and a compounding layer of dumagat prejudices against people they presume to be savages. It is the perfect storm of power-saturated ${ }^{15}$ interactions that both magnifies the Philippine state's existing vulnerabilities to graft and influence peddling - what Thomas McKenna (1998:130) refers to euphemistically as 'possibilities for self-enrichment' within the civil service - and increases the vulnerability of minority IP's to exploitation by the ethnic majorities. This vulnerability is also physical, in the literal sense that moving about in the foreign dumagat world is also extremely stressful to Higaunons, with the heat, noise, pollution, crowding and hurried pace of lowland towns often triggering headaches and other physical maladies that discourage them from persisting in such encounters.

As a result, clientelistic third party assistance is often sought by Higaunons even for such basic tasks as obtaining identification papers, filing tax forms, school registration, claiming and collecting government benefits, or opening a basic bank account. For more complex procedures such as raising funds for a community development project, registering a community organization with the Securities and Exchange Commission, or applying successfully for a government reforestation grant, direct intervention by a third party is often required in order to navigate the bureaucratic maze in a timely manner. This state of affairs has prompted Higaunons to not only accept but actively cultivate patron-client relationships with outsiders (such as government officials, merchants, NGO workers, local functionaries, politicians, wealthy individuals) who might be able to help them navigate the dumagat world and mobilize even the most basic resources to which they are already entitled either as citizens under Philippine law or as IP's under the IPRA.

14 The dominant dumagat language in northern Mindanao is Cebuano Visayan, which most Higaunons pick up either from their settler neighbours, from their classmates at school, or from their travels to the coastal markets such as those in Gingoog City. Whilst some school-age children have a limited fluency in Tagalog and English, very few adults possess more than a rudimentary vocabulary of Tagalog and English words. It is still possible to this day to find children growing up immersed in a Higaunon-only linguistic environment. Adults who do not travel regularly outside this environment may have some understanding of Cebuano Visayan, but not enough to speak it. Higaunons are thus doubly disadvantaged in terms of language.

I use 'power-saturated' here following Tania Murray Li's (2001) usage. 
In the process, Higaunons also come to embrace the material aspirations of lowland culture that they observe to be necessary for mainstream 'success' (such as formal schooling, urban life, full linguistic competence in dumagat languages, intermarriage with dumagats) in order to ease their movements in modern Philippine society. In other words, Higaunons fully understand that, in today's democracy, being more dumagat and less Lumad makes their lives easier, even if it means that they must face the very real dilemma of losing touch with their own culture and identity as they are pushed by well-meaning outsiders - and most often, by their own parents and elders - towards perfecting their assimilation into the dumagat world.

Amongst the Higaunon, I have observed on the one hand how, in the past two decades, state practices have genuinely transformed how they conceptualize their relationship to the national government, their received notions of 'citizenship' and 'democracy', and their growing identification as 'Filipino'. On the other hand, I have also observed how government decentralization has actually complicated and increased the bureaucratic contact required of IP leaders to take care of basic tasks of governance and provide social services and economic opportunities for their communities, as part of this quest for more involved citizenship. This in turn is transforming substantially their traditional notions and practices of governmentality as well as replicating, slowly but surely, the predatory and exclusionary aspects of Philippine national tra$p o^{16}$ politics. In other words, the pursuit of greater democratization, primarily through the principles of government decentralization and participatory development in both local government units and tribal affairs, is instead reproducing the predatory politics of the Philippine state, engendering gross power inequalities and political exclusions within small, kin-based, and libertarian Lumad communities. These new disparities, in turn, are causing troubling new entanglements that undermine indigenous governance.

\section{Political Leadership among Higaunon Lumads}

For outsiders and 'insiders' both, it is quite a challenge to get a grip on the internal politics of the Higaunon. This is because in public they emphasize consistently a high degree of social cohesion and solidarity, yet they are in fact highly individualistic, acting on a distinctly libertarian ethic. This is due in

16 Trapo is a Philippine term for a rag used for cleaning, widely used as a metaphor for corrupt or 'dirty' politicians. It is a play on words derived from the first syllables of the ironic phrase 'traditional politician'. 
part to demographic factors: their settlements are normally small-scale and almost entirely kin-based, with multiple closely-related family groups living in a specific territory delineated by their founding ancestors. They tend to be organized in loose, settlement-specific, and communalistic power structures headed by one or more men of high esteem, called datu, who descend from the founding families, the ininay daw inamay. ${ }^{17}$ Respected women from these families also take on very similar roles, with the title of bae, ${ }^{18}$ and in recent times many bae have risen to prominence in communities with less-than-effective male leadership.

According to Higaunon customary law (bungkatol ha bulawan), each settlement's founding families remain paramount in all things, with exclusive jurisdiction over land rights and political authority. Even though in-laws and others are often welcomed as new residents, only the ininay daw inamay may become datu or bae for a given territory. However, this still means that nearly all Higaunons have the right to put themselves forward as potential datu and bae in their home communities. In fact, each settlement, no matter how small, always has multiple datu and bae at the helm. Finally, though membership in the ininay daw inamay lineages is an ascribed status, leadership itself must be individually achieved. In other words, datuship involves heredity, but is not hereditary.

The ideal characteristics of a datu or a bae are: a definitive knowledge of customary law, mastery of the panud (oral history), commitment to the community, the ability to listen to others and treat everyone fairly, the ability to generate a public consensus, personal humility and a distaste for attentionseeking behaviour. They are not only community leaders and adjudicators of customary law, but are also the repositories of oral traditions as well as secret knowledge passed down from the ancestors. As such, the datu or bae is a living embodiment of Higaunon law, cultural tradition and historical memory. The datu or bae are thus the designated 'culture-bearers' of their communities, rather than holders of a particular political office. They are trained by their elders, under whose tutelage they ultimately matriculate in a sacred ritual called the dumalungdong, during which they receive their sacred datu name from the spirits. While in communication with outsiders, Higaunons freely refer to each other as datu or bae, but in fact only a handful of such individuals actually undergo training, and even less have ever been confirmed through the formal ritual. Within this small group, there are even fewer datu who would be regarded by Higaunons as truly embodying what, in their minds, is a 'real' datu.

17 This phrase refers literally to the original mothers and fathers (of the land).

18 The word is an honorific version of baye ('woman'). 
At the same time, however, Higaunons recognize that someone who adheres religiously to the bungkatol ha bulawan is the antithesis of the kind of leader present political circumstances require. And this is the point at which the question of indigenous leadership grows rather complicated.

To an outside observer without any prior experience of Higaunon customs, it would be difficult generally to guess who the true leaders of a community may be, because the 'traditional' datu and bae tends to be rather introverted, and the polar opposite of what dumagats would typically recognize and require in terms of political leadership. In public meetings and discussions I have observed, typically the most highly regarded datu in the room listens silently as everyone else voices their opinion, speaking up last and only to summarize and validate the points of view expressed and propose a way forward, at which point another round of opinion and debate often begins. However, it is also common to see a few men stand up and state their opinions vociferously, sometimes with such eloquence and force that an outsider would easily mistake them for the leader of the group. This is, after all, how dumagat politicians behave. But to Higaunons, such bluster is unimpressive because aggressive speech is seen not only as rude but also a mark of political immaturity. It is a subtle cultural difference that creates a fundamental problem of communication (and therefore governance) between Lumad peoples and state officials.

\section{The Rise of the Government datus}

The word datu is routinely translated into English as 'chieftain', inviting an automatic comparison and conflation with chieftains of the European, Native American or Polynesian model. However, the Higaunon datu does not appear to be like any of these types, nor even like the 'big-man' once described by Marshall Sahlins (1963) for Melanesia. For one, there are often quite a few datu in any given community, none with actual legal authority over the rest. Nor are individuals obliged to follow blindly the commands of a datu, in part because the status differences within Higaunon society do not extend to hierarchies of rank or class. While it remains poorly understood, it is fair to say that Higaunon customary law, as a political system, does not encourage the establishment of a centralized leadership, a permanent power hierarchy, or the significant accumulation of power by one individual. Instead, it demands consensus and engenders the cooperative dispersion of power. All the same, outsiders seem to expect, even require, a certain type of community leader, especially when it comes to dealing with the demands of participating in a modern democratic society. In response to the requirements of interacting with the state, local 
politics, the local market economy, non-governmental organizations and other outsiders, a new type of indigenous leader has evolved convergently in Lumad communities all across Mindanao.

The siptin, as s/he is called by the Higaunon as well as by other unrelated Lumad groups, is a relatively new type of tribal leader who stands as the political and legal representative for his or her community, the point-person for dealing with outsiders. S/he also gives the impression of an overall ruler who appears to make decisions on behalf of the whole community and likewise is generally held as responsible for enforcing community rules. In a nod to modern democratic ideals, a community's siptin is typically selected by consensus amongst the various datu and bae, and is open equally to women and men. It seems to be evolving into a universal type of tribal leadership role, such that the siptin appears to be generic across all the Lumad groups.

Siptin is, of course, derived from the English word 'chieftain', a word that has been internalized by Higaunons and other Lumads. There is no equivalent indigenous term in any Lumad language. It is fair to say that the role of siptin was not only created in order to conform to outsiders' expectations, it is a concept that has been imported wholesale from contacts with state bureaucracy. In the 1980 s, tribal communities wishing to interact in an official capacity with the national government (when Lumads fell under the auspices of the Office of Southern Cultural Communities) were required to provide first a list of 'tribal officers' for their 'tribal council', beginning with the 'chieftain' and going down the line to treasurer, secretary, sergeant-at-arms and other such officers normally found in the student councils of the Philippine elementary and secondary school system. In those days, such positions were filled almost randomly, with no correlation between title, function, or actual leadership status. Tribal councils were created ad hoc simply because the government required the paperwork, whether it was used to register a general complaint with the national government or to file an ancestral land claim.

Today, tribal councils are taken seriously, and have become an important organizing mechanism for communities with official ancestral land claims. In such cases, they form an important part of the actual leadership structures on the ground, as IP communities attempt to harmonize their political systems with that of the national government. But a designated 'chieftain' is still required, and so the siptin has become normalized within the indigenous political system. Amongst the Higaunon the office of siptin is not necessarily held by a ritually confirmed datu or bae, much less the highest ranking one amongst them. In fact, in two Higaunon communities I know well, neither siptin is ritually confirmed, but simply a member of the tribal council who was selected by the majority to do what none of the other datu or bae want to do, which is 
deal with outsiders. Often it is someone who is more at ease in dealing with dumagats, and more literate in the languages of government (Tagalog and English) than the rest.

Whilst the siptin may be referred to by the community as a datu or bae in the presence of outsiders, within the context of Higaunon customary law they are basically what other datu refer to as a datu ha gubilnu or 'government datu.' This is to differentiate the leadership of a siptin from that of a datu who follows the bungkatol ha bulawan, and who might therefore be called more properly a datu ha kultura or 'cultural datu'. Whilst undeniably a leader within the context of customary law, a well-respected cultural datu tends to be ineffective as a community interface in the power-saturated bureaucratic environment of the lowlands, due to the very nature of his vocation that prioritizes the preservation and proper exercise of cultural knowledge, and social protocols over the accumulation of individual power and influence.

The siptin is not the only 'government datu' to be found in the modern political system of the Higaunon. An equally important role may also be played by the sirman (from 'chairman'), who is the individual on record as the official holder of the community's Certificate of Ancestral Domain Claim or Title (CADC/CADT). In all the communities with which I am familiar, the role of sirman is never assigned to the same individual as the siptin, perhaps as a nod to the Higaunon ethos against the concentration of power. Like the siptin, however, the sirman is also selected for his or her ability to deal effectively with outsiders and represent the community, as needed, in dealings with the government. Also in the sirman's portfolio is responsibility for the actual management of the ancestral domain, as required for every CADC and CADT. This includes planning, applying for public and private funds, and organizing the community to implement any development strategies for the land, in fulfilment of IPRA requirements.

Though quite a recent invention of government bureaucrats who were concerned primarily with environmental protection, the concept of 'ancestral domain' in fact harmonizes easily (though not completely) with Higaunon ideas about both land tenure and governmentality. The participatory development aspects of the IPRA law also comport with the Higaunon ethos of listening and consensus-building. The Higaunons have therefore embraced the IPRA and taken advantage of it as much as possible. Among the Lumads, the Higaunon sub-groups have been the most involved in ancestral domain claims, with most communities filing official claims for recognition of their lands, or in some cases combining resources with neighbouring communities to file socalled 'unified' ancestral domain claims involving a much larger contiguous territory. 
While these domains are supposed to be autonomous and administered through the national government via the National Commission on Indigenous Peoples (NCIP), in practice all IP's, being Philippine citizens, must also articulate with the decentralized local government unit (LGU) system. This means that, in addition to customary law and the government's 'tribal council' system that has created siptins and sirmans, IP's are also incorporated into their corresponding LGUS, through which they exercise their right to vote, enter the public education system and connect with other aspects of the government bureaucracy that are not available through the NCIP. The LGU system also requires local residents to participate in their own governance, particularly at the basic level of the barangay, the smallest autonomous LGU. It is within this muddled articulation of mismatched indigenous, national and local structures that problems of governance are prone to arise.

In Higaunon areas, the barangay council might be made up of an assortment of citizens - including datus and baes of different types, ordinary Higaunons, and dumagat settlers. I know of many cases in which a cultural datu or bae also serves as a barangay officer, as well as a tribal council member for the ancestral domain. On the other hand, ancestral domains do not usually correspond to LGUS, and may even cut across more than one province or region, whilst a single barangay might encompass part of one domain but not the rest. Keeping track of these separate jurisdictions can be tricky for leaders and constituents alike, yet their considerable overlap in terms of people and places means that decisions made in one jurisdiction will inevitably have an impact on the others. In essence, interacting with the government has necessitated the creation of a new governing structure, parallel to Higaunon customary law, to enable community leaders to deal with these novel bureaucratic demands. The problem is that the corresponding mode of leadership that has emerged in this context operates on principles that are in direct conflict with traditional indigenous leadership.

To be sure, Philippine government bureaucracies can be gloriously inefficient and incompetent at any level. But the real problem lies in the fact that IP's have very little control over the multiple processes that affect them directly; the resulting jurisdictional confusion only amplifies their political vulnerabilities. Among the Higaunons, the problem appears subtle due to their extensive ancestral domain claims, their active participation in local government structures and other efforts to make themselves and their concerns visible to the state. But the truth is that, given the cultural, educational, economic and other disadvantages of Higaunons, it is still rare to find an indigenous leader - whether datu, siptin, or sirman - who is capable of dealing with the government bureaucracy, or the CADC/CADT requirements, or other matters 
entirely on his or her own. When circumstances require some degree of technical expertise or political networking, third party assistance, mentioned previously, typically comes into play. For example, as CADC or CADT 'holder,' the sirman typically turns to outsiders to facilitate their management plan, either through technical expertise (in agriculture, forestry, et cetera), fundraising, or even creating the management plan itself. According to the IPRA law, the NCIP is supposed to act as facilitator in such matters, but due to lack of funds and personnel they openly encourage IP communities to pair up with local or international NGOS who can provide the necessary technical assistance as well as the funds required to complete the many requirements of CADCs and CADTS. Furthermore, the assistance or patronage of third parties is often necessary for facilitating matters well beyond the management of ancestral lands, and NGOS, church-based social welfare groups and private individuals can easily carve out for themselves a role to play in bridging the gap between what is required of Higaunons and what they are able to provide on their own.

Sometimes 'facilitation' is simply a matter of advising or providing technical assistance, and sometimes it is a simple matter of aiding communication between an IP group and the government. Sometimes it involves merely providing background support to ensure that Higaunon are treated fairly and their rights are protected. For example, qualified Higaunons applying for college scholarships (to which they are entitled as IP's) are typically asked for a pile of paperwork (including certified birth certificates, et cetera) and official endorsements that may be costly or otherwise difficult to obtain, especially for the poor and disenfranchised. The process has been described to me by Higaunon students as not only daunting but also dizzying (both figuratively and literally), as they are usually sent around town to different government offices to chase down the required paperwork. The process is also deeply political, in that the endorsements are required from petty local officials in the local government unit and the NCIP, some of whom have been known to withhold their approval until they have been assured of political loyalty by the student's family, or in some cases, have extracted a bribe from already cash-poor students. ${ }^{19}$

19 One particular lower-level NCIP official is notorious for withholding scholarships - or absconding with them altogether - unless a student first 'shows her gratitude' by, for example, topping-up minutes for his prepaid mobile phone or 'giving change' for a large denomination peso bill that he never actually hands over in exchange. However, I hasten to point out that this is atypical and that all other NCIP officials I have met personally in fact do their work in a highly professional manner even with limited resources. The IP's grumble but are unwilling to file a formal complaint, fearing retaliation against their families due to the official's political connections. 
Students may therefore turn to third parties to either 'walk' their paperwork past such hurdles, or else give up on higher education altogether.

For Higaunons, the bureaucratic difficulties they routinely encounter are so overwhelming that it may well be impossible to complete even basic paperwork without the intervening gaze of outside observers. Whether this is merely a reflection of Higaunon insecurities or is due to active racial discrimination by dumagats, it highlights the very real cultural gulf between Higaunons on one hand and the dumagats (including the state that represents them) on the other. As a consequence, the interaction between 'indigenous' and 'state' political frameworks is so dependent on third party 'facilitators,' enabling outsiders to accumulate in the process a level of power and influence wholly disproportionate to their official position (if any) within either framework.

Amongst outsiders, the potential for real abuse is tremendous. In general, Higaunon communities are so vulnerable to exploitation and corruption that any individual with even modest financial means could easily amass great influence by providing scholarships for higher education or paying for emergency medical needs. ${ }^{20}$ Someone acting as a facilitator could become indispensable to community leaders as a government intermediary or 'fixer'. They could then turn around and exert undue influence over the tribal council, and over important matters like elections, or allowing the entry of logging or mining companies into an ancestral domain.

Within Higaunon society itself, the 'government datu' types like the siptin quickly acquire higher status within the community than they might otherwise possess within the bounds of customary law. In terms of pressing modern community needs like education, healthcare and the management of the ancestral lands, the siptin and sirman have now become essential political actors in a way that the 'cultural datu' may never be. As such, there is a serious power imbalance developing between the traditional political authority of the cultural datus and the rise of the government datus as a new locus of indigenous authority. Within the Higaunon context, the conceptualization of what constitutes legitimate political authority is now very much in flux.

Such competition for authority may well be unavoidable in the modern political context. However, the situation is complicated by the attempts of Higaunon datus to reconcile the authority of these new political actors within indigenous tradition and regulate their power by bringing them under the jurisdiction of the bungkatol ha bulawan or customary law. Inevitably they do

20 Paying for education and emergency medical care seem to be the two most pressing monetary needs amongst Higaunons in Misamis Oriental. 
this the only way they know how: by ritually confirming these new essential actors as datu or bae which, from the Higaunon point of view, formalizes a lifetime commitment to the community. The problem, of course, is that such individuals will not have undergone the years of training and testing normally considered necessary for a datu or bae to be confirmed. This means that they are unlikely to understand the bungkatol, much less consider themselves bound by it.

While all Higaunons recognize the need to accommodate the 'government datu' for the greater good, the principal danger lies in conferring the mantle of legitimacy on individuals who lack the requisite cultural knowledge. This in turn contributes to the growing political schism between the cultural and government datus within Higaunon society. Higaunons use black humour to critique this state of affairs, through the caricature of 'Datu Hag-as', whose ritual confirmation comes so quickly and prematurely that his 'sacred' name translates into English as 'Datu As-If.'21 Whilst this caricature definitely pokes fun at such datus - who are universally perceived as illegitimate or 'fake'- it is even more scathing a critique of the datus who sponsor such men for the sake of political expediency.

It becomes a different problem altogether when the datus allow the confirmation of non-Higaunons through the dumalungdong ritual. Heavy criticism is always levelled against those datus who do so in order to curry favour with potential dumagat allies. Local dumagat politicians, for example, are the usual beneficiaries of such honorary titles, as they are often useful in terms of political patronage. For the most part, the practice has proven relatively harmless, as such honorary datus or baes tend to disappear from Higaunon life afterwards. This is because they regard their titles primarily as touristic novelty or entertainment, rather than as a serious moral obligation to an IP community. However, this practice has also caused serious problems, as in the case of two 'fake' datus who attempted, in separate instances, to seize legal control of Higaunon territory by presenting themselves to state authorities as legitimate Higaunon datus.

The anomalous scenarios described above are a political reality today primarily because of the procedural gulf between Higaunon customary law and the state bureaucracy. In a sincere effort to render themselves more visible to the state, Higaunons have essentially 'invented' a parallel mode of governance

21 Hag-as in Cebuano Visayan is an expression that refers to something that happens suddenly, without precedent and for no apparent reason, implying that it is invalid, illegitimate, or otherwise highly suspect. 
that has proven practical and efficient, but also highly dissociative, with the government datu not only standing as the public alter of the 'real' datu, but ultimately pushing him aside. Meanwhile, the reliance on political patronage and third party facilitators leaves Higaunons and their loose, acephalous political system open to fraud, corruption, and abuse by outsiders like unscrupulous public servants and the 'fake' datus described above. While this has been a problem for decades, it has grown more acute with increased government decentralization and the continued administrative separation of IP's.

\section{Custom and Citizenship in the Philippine Uplands}

Higaunons do blame dumagats for many things, but the widespread loss of cultural knowledge and respect for tradition is blamed primarily on the shortsightedness of other Higaunons. This is in part due to the extensive adaptations to dumagat society and to the Philippine state that Higaunons have made over the past few decades. Despite their historical resistance to state and settler encroachment on their ancestral lands (Paredes 1997), Higaunons have made deliberate efforts since the 1990s to cultivate what they consider to be 'proper' citizenship in an effort to identify themselves as Filipino. For the most part this has involved assimilating where possible into dumagat culture, to make themselves appear less 'savage' and more 'citizenly' to dumagats. Yet the past two decades have witnessed a more substantial transformation in terms of Higaunon identification with the Filipino nation. Until the early 199os, within the context of intense, sometimes violent ancestral land struggles prior to the passage of the IPRA law, all my adult informants supported the idea of armed resistance against the government. Most expressed primarily separatist concerns: they wanted the dumagats to leave them alone, and the popular view was that anyone who married a dumagat was no longer a Higaunon. It was also considered acceptable to keep children out of the school system because it was deemed a dangerous distraction from the essential cultural formation of a Higaunon. This resistance to free government schooling was experienced by many datus born as late as the 196os, who form the main cohort of active community leaders at the moment.

Today, however, the same cohort appears primarily concerned with exercising their voting rights, registering as taxpayers, acquiring official birth certificates for their children and making great sacrifices to ensure that they finish school. They also take every opportunity to sign up for government programmes, dumagat associations, NGO programmes, church rosters and other ways through which they can signal their official membership in Philippine 
society. It is common, for example, for Higaunon males to possess an impressive array of papil (paperwork) identifying them as members of multiple churches as well as members of seemingly random dumagat associations. ${ }^{22}$ While they do discuss these activities, especially schooling, in the context of economic advancement for their families, they consistently refer to a desire to be recognized as being equal to other Filipino citizens. In their minds, bureaucratic visibility is the key to establishing their cultural legitimacy as citizens. Becoming Christian is also a popular choice, and Higaunons have joined any number of Christian sects active in their area, with some even forming their own Higaunon churches (Paredes 2006).

This has resulted in a novel dilemma for Higaunons. On a superficial level, cultivating proper citizenship has meant largely conforming to dumagat cultural markers such as education, wage labour, city attire and immersion in Filipino popular culture. With regard to political leadership, everyday realities necessitate the nurturing of individuals who are capable of interacting effectively with outsiders, and those who show intelligence and leadership ability are being encouraged generally to pursue formal schooling in the lowlands rather than training to be a datu. The ultimate goal, according to the datus I have interviewed, is to create a cadre of effective mediators and power brokers to protect the community's minority rights and other interests vis-à-vis the state and civil society. However, emphasizing assimilation and accommodation means de-emphasizing more Higaunon concerns, like the bungkatol ha bulawan, the oral traditions and cultural practices that might be perceived by dumagats as 'primitive'.

Meanwhile, Higaunons continue to pay lip service to the importance of cultural datus all the while pushing the next generation away from cultural datuship and down the path of dumagat assimilation, creating leaders who are culturally competent in the lowlands but detached from their own ancestral traditions. At the same time, the cultural datus are criticized for their general ineffectiveness in dealing with the pressing economic and political problems of Higaunon citizens in modern Philippine society. In day-to-day community affairs, the cultural datus are routinely pushed to the sidelines while siptins, sirmans and others who have networked with dumagats and outsiders for

22 However, most of these papil tend to be unofficial, and rather dodgy. I have even heard some older Higaunon men (who tend to be illiterate) claim that they didn't know what the organization actually was, and that they signed up only to have something with their name written on it. The possession of official government-issued identification papers the type that allows one to open a bank account or apply for a passport - remains relatively rare. 
political expedience have now become indispensable and, perhaps, a 'necessary evil.' As the politics of heritage becomes increasingly entangled with the politics of representation, the struggle between cultural and government $d a-$ tus complicates even further the goal of preserving Higaunon cultural heritage and ancestral lands. It seems inevitable that as they succeed in becoming more 'citizenly, Higaunons and other IP's will lose touch with the ancestral traditions they have been fighting for.

The Philippine state's pursuit of a more inclusive democracy - in particular through 'participatory' approaches in development and governance - has, in a sense, opened up for Higaunons and other IP's a wider range of possibilities to assert their legal citizenship and expand their cultural citizenship. However, in valorising clientelistic dependence on more powerful and influential outsiders, their increased political participation also makes Higaunons vulnerable to more exploitation than was possible previously. Decentralization, in particular, has created new gaps that not only allow but virtually require the intervention of resourceful individuals who can mobilize government and other resources, as well as bridge the procedural gaps between indigenous and state systems. Unfortunately, the quotidian IP experience of democracy, as shown in the Higaunon case, is coloured significantly by the quality of the individual who steps into the breach. Whilst the process is breeding a new political elite amongst educated IP's who are more capable interlocutors vis-à-vis dumagat culture, it is also giving disproportionate power and authority to those who operate without the social and moral encumbrances of customary law. The most troubling aspects of the Higaunon case illustrate for us a defining irony of modern Philippine democracy: that the 'participatory' approaches advocated so often and so enthusiastically in fulfilment of the liberal, progressive ideals of inclusive citizenship, may in fact be transforming the IP's into 'new subalterns,' following Spivak (1999), whose exploitation is 'achieved precisely through the mobilization...of participation and empowerment in order to co-opt the local agency of communities at the margins within the neoliberal framework' (Dutta 2012:74). In other words, in their pursuit of empowerment - in this case through fuller citizenship and greater political participation as modelled by Filipino/dumagat culture rather than their own - Higaunons and other IP's may be instead achieving the opposite.

In the political context of Mindanao, citizenship has long been conceptualized, experienced and achieved differently by the minority IP's than the majority dumagats. As Rosaldo (2003:13) explains in his volume on cultural citizenship in the uplands of island Southeast Asia, cultural citizenship is about 'the kind and extent of participation by varied groups and individuals with different social projects'. For marginalized IP's in the peripheries of the 
nation-state, the politics of difference means that the state orders and 'constructs hinterland ethnic groups and...simultaneously excludes them from full citizenship' (Rosaldo 2003:14) in the process. If 'citizenship' is the precondition for having rights, at present the recognition that IP's 'belong' fully in Philippine society depends almost entirely on how they fit into preconceived notions of 'Filipino-ness'. As such, the more that Higaunons and other IP's struggle to 'belong' in this manner, the more they lose the cultural distinctiveness that makes the pursuit of fuller citizenship relevant in the first place. Their future in Philippine society will depend entirely on how they manage to challenge and transform the state's own cultural construct of citizenship.

\section{References}

Barter, S.J. (2015). 'Second-order' ethnic minorities in Asian secessionist conflicts: problems and prospects. Asian Ethnicity, 16(2), 123-135.

Brosius, J.P. (2003). The Forest and the Nation: Negotiating Citizenship in Sarawak, East Malaysia. In R. Rosaldo (Ed.), Cultural Citizenship in Island Southeast Asia: Nation and Belonging in the Hinterlands (pp. 76-126). Berkeley, CA: University of California Press.

Dutta, M.J. (2012). Culture-Centred Approach to Social Change Communication: Structure, Culture and Agency. In S. Melkote (Ed.), Development Communication in Directed Social Change: A Reappraisal of Theory and Practice (pp. 53-79). Singapore: Asian Media Information and Communication Centre.

Gaspar, K. (2013, October 10). The Politics of Statistics Involving the Lumad. Mindanews. Retrieved from http://www.mindanews.com/mindaviews/2013/10/10/a-sojourners -view-the-politics-of-statistics-involving-the-lumad/.

Hodgson, D.L. (2011). Being Maasai, Becoming Indigenous: Postcolonial Politics in a Neoliberal World. Bloomington, IN: Indiana University Press.

Li, T.M. (2001). Masyarakat Adat, Difference, and the Limits of Recognition in Indonesia's Forest Zone. Modern Asian Studies, 35, 645-676.

May, R.J. (2009). Federalism vs. Autonomy in the Philippines. In B. He, B. Galigan, \& T. Inoguchi (Eds.), Federalism in Asia (pp. 165-187). Cheltenham, UK: Edward Elgar.

McCargo, D. (2011). Informal Citizens: Graduated Citizenship in Southern Thailand. Ethnic and Racial Studies, 34 (5), 1-17.

McKenna, T. (1998). Muslim Rulers and Rebels: Everyday Politics and Armed Separatism in the Southern Philippines. Berkeley, CA: University of California Press.

Montiel, C., Rodil, R., \& de Guzman, J. (2012). The Moro Struggle and the Challenge to Peace Building in Mindanao, Southern Philippines. In D. Landis \& R. Albert (Eds.), 
Handbook of Ethnic Conflict: International Perspectives (pp. 71-9o). New York, NY: Springer.

Paredes, O. (1997). Higaunon Resistance and Ethnic Politics in Northern Mindanao. The Australian Journal of Anthropology, 8, 270-290.

Paredes, O. (2000). Discriminating Native Traditions Among the Mindanao Lumad. In C. Macdonald \& G. Pesigan (Eds.), Old Ties and New Solidarities: Studies on Philippine Communities (pp. 74-9o). Quezon City, Philippines: Ateneo de Manila University Press.

Paredes, O. (2006). True Believers: Higaunon and Manobo Evangelical Protestant Conversion in Historical and Anthropological Perspective. Philippine Studies, 54 (4), 521-559.

Paredes, O. (2013). A Mountain of Difference: The Lumad in Early Colonial Mindanao. Ithaca, NY: Cornell University SEAP Publications.

Paredes, O. (2015). Indigenous vs. Native: Negotiating the Place of Lumads in the Bangsamoro Homeland. Asian Ethnicity, 16(2), 166-185.

Rosaldo, R. (2003). The Borders of Belonging: Nation and Citizen in the Hinterlands. In R. Rosaldo (Ed.), Cultural Citizenship in Island Southeast Asia: Nation and Belonging in the Hinterlands (pp.1-15). Berkeley, CA: University of California Press.

Sahlins, M. (1963). Poor Man, Rich Man, Big Man, Chief: Political Types in Melanesia and Polynesia. Comparative Studies in Society and History, 5 (3), 285-303.

Spivak, G. (1999). A Critique of Postcolonial Reason: Toward a History of the Vanishing Present. Cambridge, MA: Harvard University Press. 


\title{
Citizenship and Islam in Malaysia and Indonesia
}

\author{
David Kloos and Ward Berenschot
}

In July 2009, an Islamic court in the Malaysian federal state of Pahang sentenced Kartika Sari Dewi Shukarno, a nurse and part-time model, to a punishment of six strokes with a rattan cane (besides a fine of five thousand Malaysian ringgit [ca. 1000 euro]) for drinking beer in public. ${ }^{1}$ Police, assisted by officials of the State Religious Department, had arrested her during one of their regular raids of holiday resorts in the region. The punishment was later upheld by the Pahang Syariah High Court. According to the judge, it was meant 'to make the accused repent and serve as a lesson for Muslims.' ${ }^{2}$ The case led to public outcry, both in Malaysia and abroad. Partly in response to this, the Sultan of Pahang interfered. The verdict was commuted, in early 2010, to three weeks of community service. Had the original sentence been carried out, Kartika would have become the first woman in Malaysia to be caned under Islamic (syariah) law. Instead, this doubtful honour went to three, less famous young women, who, after being sentenced for having pre-marital sex with their boyfriends, were caned between four and six times in a prison in the state of Selangor in February 2010. They had turned themselves in after realizing that they were pregnant.

In the Malaysian Islamic legal system, which exists side by side with the civil judiciary, caning may be meted out as a punishment for (particular) breaches of Islamic (syariah) law, including adultery, the use of intoxicants (such as alcohol) and apostasy. At present, three federal states (Pahang, Perlis and Kelantan) have implemented such punishments. Hudud laws, which enable Quranic (corporal) punishments, were first formulated in the states of Kelantan (1993) and Terengganu (2002), where the Islamic party PAs formed the local government. They were heavily contested from the beginning. Except for the punishment of caning, law enforcement institutions (which are controlled by the federal government) have refused to enforce syariah criminal enactments. However, at present, the United Malays National Organisation (UMNO) - the ruling party at the national level since independence in 1957 - is considering the implementation of hudud laws at both state and federal levels. A similar pattern can be

1 We thank our interlocutors in Malaysia and Indonesia for their willingness to share their opinions and experiences with us. We thank Chris Chaplin, Ton Groeneweg, Henk Schulte Nordholt, and an anonymous reviewer for their helpful comments on an earlier version of this chapter.

2 'Malaysia to cane beer-drinking Muslim model,' Al Arabiya News, 21 July 2009.

(C) DAVID KLOOS AND WARD BERENSCHOT, 2017 | DOI 10.1163/9789004329669_009

This is an open access chapter distributed under the terms of the CC-BY-NC-ND License 
observed in Indonesia where local governments have created a range of syari$a h$-inspired bylaws, most of which are directed at matters of public morality. In the province of Aceh, where the right to implement syariah law was part of a broader autonomy package intended to put an end to a decades-long civil war, an Islamic criminal code has been implemented since the early 2000 .

These developments can be interpreted as a sign of the increasing strength and appeal of political Islam, in combination with the influence of transnational organizations and networks (Van Bruinessen 2013), or explained as a result of the growing anxiety about religious identities (Sidel 2006). But they also indicate changing interpretations of the 'proper' relation between state and citizen. The implementation of syariah-based laws in Malaysia and Indonesia amount to a reconceptualization of the positions of individual citizens vis-à-vis the state and other citizens. From a liberal-secular perspective, they amount to a massive infringement of personal freedom, an attack on women's rights, an unwarranted foray of state institutions in religious matters, and an intrusion of the state into the private sphere. From forbidding women to go out after dark, punishing homosexuals, penalizing extra-marital sex to banning alcohol and prescribing modest dress, they do not just impose physical punishments for moral transgressions but also aim to regulate several aspects of people's private lives. As such, they institute a form of differentiated citizenship, imposing different behavioural standards on Muslims and on women.

Yet, the lively and very heated debates about syariah-based regulations in Malaysia and Indonesia are rarely waged in liberal or secular terms. In both countries, NGOS and religious leaders engage in public campaigns to support, adjust or counter the institutionalization and enforcement of Islamic morality, while 'ordinary' Muslims often express a critical stance toward the advances of normative Islam generally (Kloos 2015; Peletz 1997). What stands out in this discussion, however, is the relative insignificance of liberal or secular discourse. Campaigns against hudud- and syariah-based regulations are not, generally, about defending individual rights. Instead, the debate is largely framed in terms of how, and in what ways, religious duties and injunctions need to be interpreted, and what role should be ascribed, in this process, to the state. In other words, conceptions of citizenship in both Indonesia and Malaysia are developing in interaction with evolving attitudes toward Islam, Islamic texts and discourses regarding 'proper' Islamic behaviour.

By this, we do not mean to say that Islamic piety and human rights (and related concepts such as pluralism or democracy) are incompatible. Quite in the contrary. As Robert Hefner (2011:60) has argued, the Muslim world in general and democratic Indonesia in particular - has been characterized, as a result of a 'remarkable historical coincidence,' by a convergence between religious revival and a widely shared embrace of democratic discourse (cf. Künkler and Stepan 
2013). Many Islamic organizations in Malaysia and Indonesia seek to strengthen the public role of Islam while cherishing, at the same time, a conception of (or debate about) (human) rights, often in the context of broader contestations about the aggressive encroachments of the state on civil society and human lives more generally. Recent survey data attest to the fact that a majority of Indonesian Muslims are attached, simultaneously, to human rights and syariah. The definition of both concepts is the subject of debate. It is important to acknowledge, however, that 'most of these Muslim democrats are not secular liberals' but, instead, 'seem committed to a third way between theocracy and secular democracy, in which 'religious principles and democratic values coexist" (Hefner 2012:61, quoting Esposito and Mogahed 2007:63).

This chapter discusses the changing role of Islam in public life in Malaysia and Indonesia, and its consequences for the nature and conceptualization of citizenship in both countries. The concept of citizenship has a secular birthmark. Western ideas about the rights and duties of individuals vis-à-vis their political community gained currency at the time when battles about a separation of state and church where being fought. Dominant theories of citizenship are shaped by liberal ideas about a separation of private and public spheres. Furthermore, in Europe's secularizing societies, citizenship came to be associated with forms of public reasoning that sought to define the public good in non-religious terms, relegating considerations about God's law or will to the margins. As Bryan Turner (1997:10) argued (for Europe), '[i]n a secular society, public debates are neither couched in the language of religion nor are they resolved by religious institutions. In this context, citizenship functions or plays the role [sic] of a secular religion. With the decline of formal religion, citizenship provides us with a common national culture, common set of identities, and a common value system.'

This kind of 'secular' public debate is rooted in Europe's history and particular Judaeo-Christian tradition (Taylor 1989). In contrast, public debates in Indonesia and Malaysia show how conceptualizations of citizenship are being shaped by different notions, including religious concepts of justice, (human) rights, mutual obligations and politicized notions of identity and belonging. These developments challenge universalist interpretations of citizenship. Different cultural and religious traditions can give rise to different conceptualizations of citizenship. As Saba Mahmood argues, 'we can no longer arrogantly assume that secular forms of life and secularism's progressive formulations necessarily exhaust ways of living meaningfully and richly in this world' (Mahmood 2005: xi). What is needed, therefore, is a recognition of 'a plurality of possibilities for rational discourse and social tolerance' (Bowen 1996:14). We need to study how the currently evolving conceptions of citizen rights and state-citizen relations develop in tandem with evolving attitudes toward religious traditions. 
That is the aim of this essay. We start by providing some historical context to interpret the current prominence of Islam in present-day public debates, identifying a number of similarities and differences between the two countries. In the second part we discuss the ongoing debates about the need for an 'Islamic state,' asking among others why this drive to institutionalize Islamic governance and morality has met with more success in Malaysia. In the third part we explore the ways in which civil society organizations have debated religious commands, drawing attention in particular to the role of divergent attitudes toward the interpretation of religious texts in the framing of these debates. The conclusion highlights the main implications of these debates for the conceptualization of, and public reasoning about, citizenship and citizen rights.

\section{Islam and the Public Sphere in Malaysia and Indonesia}

'It makes me feel a better person', says Wibi, a twenty-year-old student of UGM university in Yogyakarta. He is talking about the usrah, the small celllike group of students with whom he studies Islam. Under the guidance of a senior instructor (ustadz), he has been reading Islamic texts and discussing their meaning in daily life. 'I used to be bad. I am ashamed to admit how I was. But tarbiyah [religious instruction] helps us understand how to believe in God and gives guidelines on how to be good. I joined them because they offer the original form of Islam, because Islam in Indonesia is distorted. And I like it that it is easy to understand. It is not at all difficult.'

Wibi is a member of a movement that during the past twenty-five years has had an enormous impact on the way in which Muslims in Indonesia, especially in urban areas and among the middle class, experience and propagate their faith. The so-called tarbiyah movement started in the early 1980 s when students - often with a background in travelling to and studying in the Middle East - started to set up local study-cells, or usrah, taking the Muslim Brotherhood in Egypt as an example. At this time, religious activities like these were suppressed by the Suharto regime, which meant that the meetings had to be carried out in secret, in private homes or at local prayer houses and mosques. In small and clandestine meetings, students were instructed in a scripturalist - sometimes termed 'salafist' (after salaf, the 'predecessors' or first generation followers of Islam) - interpretation of Islam. In contrast to the teachings in most religious schools in Indonesia, and especially the traditional religious institutions known as pesantren, the focus was not so much on the study of Islamic jurisprudence and other classical subjects (such as mysticism, or tassawuf) but on the study of the foundational texts, the Quran and hadith, and 
the ways in which daily life should be brought in accordance with the prescriptions set out by these texts and the example set by the Prophet Muhammad and his companions. The movement spread gradually, especially on university campuses, and by the time of the fall of Suharto, in 1998, it constituted a large but shadowy network that played an important role in the propagation and gradual adoption of a new, more strict form of Islamic piety.

As the cells operate rather autonomously, there is no clear organizational structure behind the tarbiyah movement. However, organizations like Ikhwanul Muslimin Indonesia (the Indonesian 'branch' of the Muslim Brotherhood), the student organization KAMmI (Kesatuan Aksi Mahasiswa Muslim Indonesia, Indonesian Union for Muslim Student Action) and the Islamist political party P KS (Partai Keadilan Sejahtera, Prosperous Justice Party) are all its products. As the network of different usrah created a committed local cadre, in the democratic era the PKs quickly evolved into one of the strongest Islamic parties in Indonesia.

A comparable development has taken place in Malaysia. Since the 1970s, increasing numbers of Muslims - including, as in Indonesia, many students on university campuses - have chosen to pursue a strict or 'orthodox' Islamic lifestyle, characterized by an engagement with religious study and the adoption of particular forms of clothing and behaviour. The Malaysian dakwah movement (after the Arabic da'wa - literally 'to call' or 'to summon') has resulted in a flowering of Islamic civil society movements, from the Islamic student association ABIM (Angkatan Belia Islam Malaysia, Malaysian Muslim Youth Movement) to the more esoteric Darul Arqam, which was banned by the government in 1994 for constituting a deviant and subversive sect. The dakwah movement also strengthened the position of the Islamist opposition party PAs (Parti Islam seMalaysia, or All-Malaysian Islamic Party), which is similar to PKS in the sense that it perceives Islamic law as the basis of both politics and society - a view that should lead, ultimately, to the establishment of an 'Islamic state' - but different in terms of its rootedness in traditional networks of religious schools (pondok) and teachers (ulama). Whereas the PKS is a product of transnational networks and linkages, PAS is both older and more entrenched in rural Malay society. Both parties, importantly, compete in elections and have shown themselves committed to a democratic system in order to reach their goals.

Besides Quranic readings, adherents of the tarbiyah and dakwah movements devote considerable time and energy to discussions about the question of how to apply Islamic teachings to everyday life in order to become better Muslims and to develop one's akhlaq, or character. As Wibi puts it: 'They teach us about the relationship with God - like how to pray and fast - and how to behave toward others, how to be honest, kind and patient, so you can learn 
about being a good human being. This seems to be the main attraction of the tarbiyah movement: its capacity to provide a clear and religiously sanctioned guidance for daily life, in combination with a strong sense of community and brother/sisterhood. As one member who detached himself from the movement says: 'We were young, so we were looking for values and perspectives regarding life, values that can help us understand what the world is like. [The usrah] offers certainty.... Our families do not help us; they do not give us a clear idea about what Islam is. Our parents do not talk about Islam. They take Islam for granted. It is just a ritual. They do not understand what Islam is. We want to know the meaning behind a statement, like the syahadat [testimony of belief in the oneness of God]. We did not get that from our surroundings.'

The emergence of Islamic piety movements is a global phenomenon. Throughout the Muslim world, an 'Islamic revival' (Mahmood 2005) has taken shape, a collection of social and political movements which emphasize a strict, literalist interpretation of Islamic norms and rules of conduct, and place great virtue in proselytization within the Muslim community. Revivalists often combine an adherence to what they consider to be 'purely' Islamic values with calls to establish a polity based on Islamic principles. While, generally speaking, the adherents of these movements constitute a minority, concentrated within the (lower) urban middle class, it is clear that ponderings about 'correct' Islamic practices have reached the capillaries of social life. In both urban and rural areas, expressions of outward piety, rather than being limited to political debate, have affected the public sphere (see, for example, Beatty 2009). In recent decades, new mosques have sprung up, syariah banking and Islamic entrepreneurship have expanded (Rudnyckyj 2010; Sloane 1999), Muslim televangelists like AA Gym and Arifin Ilham have acquired superstar status (Hoesterey 2015; Howell 2008), and urban Sufi groups have organized conspicuous, highly publicized, mass zikir (religious chanting) sessions. At the same time, expressions of religiously inspired popular culture (books, magazines, films, music, blogs, et cetera) have spread across the Muslim world (Fealy 2008a; Weintraub 2011). One of the most generally visible and conspicuous changes, however, is the widespread adoption of Muslim dress. Whereas in the 196os, the sight of headscarves in Malaysian and Indonesian urban centres was still rare, today such garment is widely considered fashionable, and in some environments (including many schools) even obligatory.

These displays of Islamic piety are commonly seen to have multiple, coinciding causes (see, for example, Fealy and White 2008; Hefner and Horvatich 1997). A general explanation has been sought in the rapid modernization that both Indonesia and Malaysia went through. Massive urbanization, combined with the emergence of a new, well-educated but precariously employed middle 
class, has created a need for new sources of stability and certainty - which a renewed faith could (at least partially) provide. This desire might have been compounded by the increased knowledge of the lifestyles and beliefs of people elsewhere in the world, stimulating a renewed examination of one's own beliefs. Another, complementary explanation is that Muslims, similar to people in the West, have experienced an 'inward turn,' inspiring individual investigations of, and reflection on, the (religious) 'self' (Robinson 2008:271-273, citing a concept developed by Charles Taylor). Ordinary Muslims as well as religious activists started to ask questions about the meaning behind the rituals they were performing, and the interpretations of texts. They became less inclined to follow established traditions. This 'objectification' of Islam (Eickelman and Piscatori 1996:37-45) meant that, for an increasing number of people, Islam became a source of wisdom to be studied and appropriated rather than a cultural tradition merely to be followed. The study groups of the tarbiyah movement catered to this need. Such an argument is supported by the observation that the Islamic revival has been, in important measure, a generational shift. In countries like Indonesia and Malaysia, it has been particularly the younger generations of Muslims who have looked for new interpretations of their faith that go beyond the religious practices of their parents (Beatty 2009; Fealy 2008a; Nagata 1996; see Herrera and Bayat 2010 for a more comparative perspective).

In both Indonesia and Malaysia, dakwah organizations were set up to spread a version of Islam that was more puritanical and formalistic than established organizations, like Nahdlatul Ulama and Muhammadiyah in Indonesia or rivalling kaum muda (young generation) and kaum tua (old generation) movements in Malaysia (Roff 1967) had ever been. The development of the tarbiyah movement was an outcome of this new associational fervour. The method of providing religious instruction through small cells proved very successful and the movement grew quickly. For some groups - particularly students in big cities - religious instruction in the usrah setting responded better to modern needs compared to the instruction provided by more established religious organizations. Students could directly consult the fundamental sources (instead of going through an extensive curriculum of Islamic jurisprudence). The relevance of these sources for daily life outside villages (from which many of them hailed) felt clear and the style of guidance less paternalistic compared to the hierarchical organization of the more traditional pondok and pesantren.

Some of these dakwah organizations are affiliated with the global salafist movement. Such organizations, like Darul Arqam, HTI or Jemaah Tabligh, are relatively apolitical, in the sense that they focus primarily on the strengthening of Islamic values by advocating a return to the beliefs and lifestyle of the Prophet and his generation. Adherents of these movements mostly concentrate on 
themselves and their close environment. They spread their message (including, in some cases, the need to establish an Islamic Caliphate on the basis of syariah law) through their study groups and preaching activities (or, in the case of Jemaah Tabligh, by travelling from mosque to mosque), activities that are often supported by Middle Eastern sponsors (Bubalo and Fealy 2005; Farish Noor 2010). Preaching a more literal, or 'scripturalist' interpretation of the Quran and the hadith, they aim to 'purify' Islam from both Sufi and local cultural elements and promote a strict adherence to the prescriptions in these texts in order to achieve a virtuous society. Members of these networks have increasingly come to populate, or even control, religious institutions, including large mosques and schools, as well as official and semi-official consultative organizations, such as the Majelis Ulama Indonesia (Indonesian Ulama Council) and the Persatuan Ulama Malaysia (Ulama Association of Malaysia).

One of the main differences between both countries is that the dakwah movement in Malaysia was, from the beginning, more politically active. For example, many members of the youth movement ABIM stood close to PAS and several ABIM leaders joined this party in the course of the 1980 . In Indonesia under the New Order there was less space for expressions of political Islam. That said, various observers have shown how the more radical networks that were outlawed by the government (such as Darul Islam) went underground in the mid-twentieth century, only to resurface - in different manifestations in the course of the 1990s and especially in the twenty-first century (see, for example, Solahudin 2011). During the final days of Suharto's New Order, the student movement KAMM I played an important role in the protests against the regime. By that time, the movement had grown so much that it could use its dedicated nationwide cadre to launch a political party, PKS.

The tarbiyah and dakwah movements are a visible and influential, but certainly not the only manifestation of the flowering of Islamic organizations. Islamic associational life in Southeast Asia has grown into an extremely diverse landscape, ranging from deeply conservative organizations and militias to groups that propagate a progressive discourse in which religious concerns converge with 'key issues such as democracy, secularism, human rights, freedom of belief, liberalism, et cetera' (Hosen and Liow 2010:1). The latter includes the spread and development of masyarakat madani, an Islamic version of 'civil society,' championed by 'neo-modernist' scholars like Nurcholish Madjid in Indonesia and former АвIM leader and Vice-Prime Minister (and current opposition leader) Anwar Ibrahim in Malaysia (Anwar Ibrahim 1996; Bakti 2005). In Indonesia, another progressive current developed within the 'traditionalist' Nahdlatul Ulama, which, in contrast to the rather elitist masyarakat madani discourse, appealed to both urban and rural, lower class constituencies 
(Van Doorn-Harder 2006:189-195; Hefner 2000). Within and between these various streams and currents, rather different positions have emerged with regard to the 'proper' role of the state and the relationship between the state and its citizens. A central issue, in this regard, is the ongoing and fierce debate about the establishment - and the nature - of an 'Islamic state.'

\section{An Islamic State?}

The growth of the dakwah movement has in both countries strengthened calls for a bigger role of the state in upholding Islamic morality, at a moment when Islam became an increasingly important tool in intra-elite competition for power and legitimacy. In Indonesia, political and public expressions of Islam had been repressed under Suharto's New Order. The only Islamic political party - the PPP (Partai Persatuan Pembangunan, United Development Party) - suffered from heavy interference and restrictions. In general, any kind of politics based on 'Ethnicity, Religion, Race and Groups' (indicated by the acronym SARA, Suku, Agama, Ras, dan Antar Golongan) was forbidden. With ethnic Chinese Indonesians playing a dominant role in business and Christians being relatively well represented in the state bureaucracy, Islam became a rallying point for those who felt treated unfairly under the New Order. As there was no other credible alternative, Islam entered the political arena as the common interest of all those who opposed the New Order and who perceived themselves to be part of the 'native' (pribumi) population. Under pressure of this discourse, Suharto felt the need to upgrade his own Islamic credentials. Thus, he went on pilgrimage to Mecca (the hajj), lifted restrictions on wearing the Islamic headscarf in schools and allowed, in 1990, for the establishment of ICMI (Ikatan Cendekiawan Muslim Indonesia, Indonesian Association for Muslim Intellectuals), which became an important channel for access to jobs and state resources (see Hefner 1993, 2000; Sidel 2006).

In Malaysia, the government party UMNO, although originally a Malay nationalist organization, has also become increasingly 'Islamic.' Prominent figures in the dakwah movement, such as Anwar Ibrahim, were co-opted into the government in an early stage. Equally importantly, the competition with PAS came to revolve increasingly around the question of which of the two represented a proper interpretation of Islam, to such an extent that both parties began to accuse each other, plainly, for being 'un-Islamic.' In some towns and villages, followers started to pray in separate mosques (Farish Noor 2003).

The Indonesian democratization process after 1998 and the electoral success of the Malaysian opposition in 2008 further strengthened Islam's public 
role. In Indonesia, responsibilities and budgets were transferred to lower levels of governments and district heads and governors became elected rather than appointed government officials. As a result, local politicians often felt a need to embrace Islam to further their electoral prospects. A public display of piety and vows to 'defend' Islam have become a common way to appeal to the electorate. Furthermore, since the first local elections in 2004, local politicians in many areas have come to rely on the support of religious leaders considered capable of swaying large numbers of voters. Their support is obtained not only by donations to mosques and religious schools, but also by promises to defend public morality. As a result of Indonesia's decentralization process, provinces are now allowed to adopt their own regional regulations, referred to as perda (peraturan daerah). In many provinces, syariah-inspired bylaws (perda syariah) aim to, for example, restrict the movements of women after dark, ban the consumption of pork, prescribe Islamic dress and punish 'immoral behaviour.' ${ }^{3}$ It should be noted that, in many cases, political pragmatism is more important than religious zeal, for the majority of these regulations have been adopted by (representatives of) secular parties, particularly Golkar (Buehler 2008; Mujiburrahman 2013). The political usage of Islamic ideology and symbolism expresses 'the resurgence of local capacities to define and exploit ideas of authenticity, autonomy and morality' (Bowen 2013:167) and, at the same time, serve to salvage the legitimacy of politicians in the face of the governance failures and rampant corruption that accompanied Indonesia's democratization process.

At the national level, Islamist politics has also scored victories, often at the cost of religious minorities, including Christians and Islamic minorities such as Shi'a and Ahmadiyah communities. The latter in particular have become targets. According to Islamist hardliners, they constitute 'deviant' sects and, as such, pose a threat to the integrity of ummah, the Muslim community (Formichi 2014; Hicks 2014; International Crisis Group 2008). Political support for literalist interpretations of Islam led to the adoption of an anti-pornography law which criminalized indigenous cultural practices while degrading women. An important factor in these developments has been the Majelis Ulama Indonesia (Council of Indonesian Ulama's, MUI), a state-sponsored but highly autonomous 'advisory' body which has local branches throughout Indonesia. The MUI has increasingly acted as a spokesperson of all Muslims. During the past decades, it has grown more and more conservative, issuing fatwas and

3 It should be noted that, except in the province of Aceh, local authorities are not officially allowed to implement Islamic law (syariah). Most of these perdas are framed in terms of adat (local customs) which does have formal legal status in Indonesia (see Buehler 2008). 
cautions against the aforementioned sects, yoga, pluralism, Facebook, as well as particular books and movies. On the streets, these larger political developments have bolstered a growth of vigilante groups that use Islam as a legitimation for their semi-illegal operations. ${ }^{4}$

To understand the increasing prominence of Islamic discourse in the public sphere, it is important to expand the analysis from contestations about Islamic orthodoxy and Islamic law to the emergence of a broader contestation about moral and religious authority in Indonesia, especially after the fall of the New Order in 1998. Accusations of heresy, and the increasing willingness of both state and non-state actors to act (violently) on this basis (with Shi'a, Ahmadis and Christians being the most prominent victims) are a primary example. While the criminalization, stigmatization and outright outlawing of socalled 'deviant' beliefs and practices has a long history in Indonesia, the past decade has been marked by escalation. Rather than a straightforward result of 'Islamization' or 'sectarian conflict' (the type of explanation commonly heard in the West), the attacks carried out against supposed deviant groups betray a fragmentation of religious authority as well as a strongly felt need on the part of religious institutions established during the New Order (such as the MUI) to reconfirm their legitimacy (Hicks 2014). In line with this analysis, Formichi (2014:24-25) notes how, during the New Order, statements by religious and political authorities about the Shi'a community being a threat to social and moral order usually followed on instances of (localized) social unrest, while in the post-New Order this order was conspicuously reversed. Democratization and decentralization facilitate these processes, as the institution of local elections put a premium on the use of religious symbols and discourse. As new local leaders struggle to establish their moral authority, they face strong incentives to strengthen their Islamic credentials by adopting outward signs of piety or invoking the need to defend Islam. Not infrequently, this extends to encouraging citizens to protect the moral integrity of their own communities, a development which, in some cases, has led to violence against those branded, for whatever reason, as 'deviant' (see, for example, Kloos 2014).

Yet, in general, Islamist organizations in Indonesia have not gone as far as their Malaysian counterparts in pressurizing the government to officialize and

4 For example, throughout Indonesia (but in large cities in particular) members of the Front Pembela Islam (Front for the Defenders of Islam, FPI) have earned a livelihood by attacking places of public vice, like nightclubs and gambling houses, as well as sects like Ahmadiyah and meetings of liberal Muslims, while claiming to be the enforcers of syariah. The extent to which their actions are motivated by either religious zeal or more worldly goals is subject to debate (see, for example, Kitley 2008 and Wilson 2008). 
enforce their particular version of Islamic morality. Of the bigger Indonesian Islamist organizations, only Hizbut Tahrir Indonesia (HTI) advocates the establishment of an Islamic state. Others, like the radically militant FPI (Front for the Defenders of Islam), call for the adoption of syariah law but stop short of calling for an Islamic state. PKS abandoned its earlier calls for an Islamic state in order to obtain more mainstream support, so that at present none of the Islamic parties represented in parliament calls for the (immediate) establishment of an Islamic state in Indonesia.

This stands in sharp contrast with Malaysia, where, as Michael Peletz (2013:609) notes in accordance with local observers, 'at present the key debates among Malay political and religious elites concern not whether Malaysia is (or should) become an Islamic state, but what kind of Islamic state it already is and what types of additional measures are needed to entrench that status' (emphasis in the original). A watershed moment, in this respect, was the 1988 revision of the Malaysian Federal Constitution - the so-called amendment 121 (1A) - which stipulated that civic courts no longer had jurisdiction over matters pertaining to Islamic law. This revision 'largely eliminated civil-court reviews and repeals of Islamic-court rulings,' while it 'also set the stage, as far as many Malaysians and outside observers are concerned, for Islamic sensibilities and dispositions to trump the Constitution' (Peletz 2013:608). Since the 1980s, state institutions such as JA KIM (Jabatan Kemajuan Islam Malaysia, Malaysian Department of the Advancement of Islam) and JAWI (Jabatan Agama Islam Wilayah Persekutuan, Federal Territory Department of Islamic Religion) have been highly active in promoting the Islamization of state and society, which includes activities such as the surveillance and criminalization of supposed 'deviant' organizations and the moral policing of local communities (Liow 2009:48-58). While PAs has called for the implementation of an Islamic state on various occasions throughout its history (see Farish Noor 2014), an important symbolic moment came in 2001, when Prime Minister and UMNo-leader Mahathir Mohamed officially declared Malaysia to be an Islamic state, a statement confirmed by Prime Minister Najib Razak in 2007.

These interventions are sensitive in multiple ways. As Michael Peletz (1997) and others have shown, 'ordinary' Malay Muslims are often ambivalent about, or even hostile to, the advance of normative Islam, but they are also generally reluctant to speak out for fear of being branded as 'un-Islamic.' At the same time, the increasing intrusion of local communities by state Islamic institutions has been seen as particularly threatening to Malaysia's non-Muslim communities. Importantly, ethnic Malays, with $51 \%$ of the population, constitute only a small majority of the nation. Unsurprisingly, the concept of an 'Islamic state' is particularly sensitive among Malaysia's non-Muslim citizens, many 
of whom feel increasingly constrained in their right to worship and observe their faith. ${ }^{5}$ Downplaying the doctrinal differences between PAS and UMNO, Liow (2009:179) notes that 'even as the Islamist opposition struggles to shed its doctrinaire image in pursuit of an agenda of reform, the erstwhile "moderate" UMNO-led government has pursued an agenda that ultimately has resulted in banning books and Bibles, demolishing temples, and constricting cultural and religious space despite a constitutionally enshrined right of freedom of worship.' As a result, 'two parallel societies - Muslim and non-Muslim - have gradually replaced what was a pluralistic, secular Malaysian society based on common law that was the legacy British colonials handed over upon independence in 1957' (Liow 2009:191).

Debates about an Islamic state in Malaysia are tied to local conceptualizations of - and contestations about - citizenship. As we have argued, an important force in this regard is the dakwah movement, an internally diverse collection of Islamic activist groups seeking a greater adherence to Islamic prescriptions in both public and private life. What makes the impact of the dakwah movement complex, however, is the fact that besides advocating Islamic issues, since the late 1990s it has also been deeply involved in the struggle for citizen rights. As part of a more general challenge against the authoritarian style of UMNO and the governing coalition (the Barisan Nasional, National Front) - commonly referred to, analogous to the Indonesian situation, as the Reformasi (reform) movement - dakwah groups like A BIM and JIM (Jamaah Islam Malaysia), together with other (religious and secular) groups, have actively condemned and resisted draconic measures and repressive policies, such as the Internal Security Act (ISA), which allows the government to detain critical or subversive elements indefinitely and without trial. ${ }^{6}$ At the level of formal politics, the Reformasi movement resulted in an unprecedented collaboration of opposition parties, the so-called Pakatan Rakyat (People's Alliance, formerly Barisan Alternatif, Alternative Front), which included PAs, the 'leftist'

5 A particularly contentious issue is apostasy. The benchmark event, in this regard, is the refusal, in 2007, of the Federal court to recognize the conversion of a woman called Lina Joy to Christianity, on the basis of the decision that this was a matter of the Islamic courts to deal with (see, for example, Kortteinen 2008). At the same time, and rather counterintuitively, it is exactly the issue of apostasy that has led to constraint with regard to the expansion of syariah as UMNO - dealing with a declining support base among Malays - has actively sought to court non-Muslim voters (Hamayotsu 2012).

6 The Reformasi movement was inspired by protests against authoritarianism in Indonesia, and broke out in 1998 after the arrest and incarceration of the popular deputy prime minister and former АвІм leader Anwar Ibrahim on charges (believed by many to be fabricated) of corruption and sodomy. 
(and predominantly ethnic Chinese) Democratic Action Party (DAP) and the progressive People's Justice Party (Parti Keadilan Rakyat or PKR) led by Anwar Ibrahim and his wife Wan Azizah Wan Ismail. While this alliance has held so far, PAs' stance on the principle of an Islamic state, and its possible consequences for non-Muslim citizens, has been a divisive issue since its inception.

In the remainder of this section, let us try to disentangle some of these issues by focusing on the views and strategies of dakwah activists in one particular locality. Comprising an island in the Strait of Malacca and a narrow strip of mainland, Penang is the largest urban conglomeration in Malaysia after the capital Kuala Lumpur. The only state in the Malaysian federation without a Muslim majority population, it is known, historically, for its multi-ethnic and cosmopolitan character. ${ }^{7}$ Since the colonial period, moreover, a broad diversity of associations and interest organizations has set Penang apart from most other Malaysian states. ${ }^{8}$ The historically lively nature of public debate and contestation in Penang allows us to explore prevalent conceptualizations of an Islamic state and concurrent ideas about, and visions of, citizenship in Malaysia.

Fadlulah Jamel is a former leader of the Penang chapter of ABIM. This Islamic youth organization was founded in 1971 and quickly gained prominence under the charismatic leadership of Anwar Ibrahim (who is originally from Penang and had been president of the National Union of Malaysian Muslim Students in the late 196os). Although in the first place a missionary organization, challenging the traditional authority of the ulama on the basis of its call for an independent reading of the Quran and the hadith, ABIM addressed from the outset a wide range of social and political problems, including poverty, corruption, the unequal distribution of wealth, the lack of political freedom and the violation of human rights (see Zainah Anwar 1987). In the late 1970s and early 1980s, many ABIM leaders decided to join political parties. While a radical

7 Penang is one of only four states which do not have a hereditary Malay Sultan as monarch, and it is the only state headed continuously (since independence in 1957) by a chief minister of ethnic Chinese descent. For almost forty years, the state government was controlled by Gerakan, which teamed up with UMNO in the National Front ruling coalition. After the elections of 2008, however, the opposition (under the leadership of the leftist Democratic Action Party) took control of the state.

8 Some historians have cited this history as an explanation for the contemporary development of civil society and the flowering of democratic political views and discourse (Kelly 2003). Other observers have emphasized the legacy of English education and the existence of a Westernized middle class imbued with 'democratic ideas and values' (Tan Pek Leng 2005:30). Such explanations are typically limited to the analysis of secular civil society. As such, they tend to conceal the extent to which religious organizations have contributed to Penang's thriving associational life, in the past and in the present. 
segment drifted toward PAS, Anwar became a member of UMNO, setting out for a political career under the wings of Prime Minister Mahathir Mohamed. As a result of this development, ABIM lost much of its vigour. Fadlulah remembered, rather bitterly, how ABIM 'just broke up,' leaving members and leaders 'stupefied' (interview, 28 September 2006). The organization continued, however, and its spirit was recovered many years later, when it assumed a leading role in the massive street protests against the 1998 arrest of Anwar Ibrahim and the subsequent Reformasi movement (see above, note 5). In Penang, ABIM cooperated on a daily basis with other interest groups including secular and non-Muslim ones. This came naturally to them, Fadlulah explained, for Malays in Penang were used to living in a mixed ethnic environment.

The struggle against authoritarianism, in Fadlulah Jamel's view, should not be regarded as a secular affair. Instead, he saw it as 'part and parcel' of Islam, a claim he substantiated by quoting a well-known hadith: 'The foremost jihad (struggle) is when you are speaking the truth in front of a tyrant.' For him, challenging authoritarian politics was not the same as discarding the need for a strong state. Moral degradation, he explained, is one of the great social problems in Malaysia, and the state should be seen as vital when it comes to combating prostitution, homosexuality, pornography, vandalism, gambling and other moral vices (such as the bad influence of heavy metal music). His ideal, he said, was an 'enlightened' Islamic state, based on the twin principles of justice and equality, both of which should flow automatically from the adherence to syariah.

He strongly resisted the view that concepts like democracy, civil society or human rights are secular or Western concepts. Instead, he argued that these principles were firmly locked in Islamic concepts such as ijtihad (independent reasoning) and shura (consultation). Asked about the shift by PAs (since the 1980s) toward a more forceful call for an Islamic state, he explained that, 'in general' this was supported within ABIM, though with the provision that such a system should not be suddenly enforced on Malaysian society. Instead, ABIM emphasized the importance of Islamic education in order to effectuate a more gradual transformation (interview, 20 September 2006).

Others adopt a less flexible stance. According to Kamaruddin Abdullah, the founder of the Penang-based Islamic Propagation Society International (IPSI) and a charismatic presence on the local stage of Islamic civil society, the process of elections in a Muslim majority country should be perceived as 'inevitably' leading to the establishment of an Islamic state. He regarded Malaysia to be 'partly' an Islamic state, and an imperfect one moreover. 'A strong Islamic state has hudud laws, strong economic laws and strong social laws.' Less concerned with the 'compatibility' between Islam and democracy, he considered 
the latter concept to be 'irrelevant.' Citing the Indo-Pakistani intellectual and political leader Sayyid Abdul A'La Maududi (1903-1979), he argued against those who associate Islam with any other kind of political or revolutionary ideology, be it democracy, communism or dictatorship. The bottom line, he explained, was the sovereignty of God. Once this was acknowledged, citizens would be equal and free, with decision making processes attuned to scriptural principles, including shura and ijma ulama (consensus among religious experts).

While it is tempting to focus on organizations with significant exposure in (local) media, like ABIM or IPSI, less visible groups can be very influential among particular constituencies, sometimes offering very different or unexpected perspectives. Teras Pengupayaan Malayu is a small NGO engaged with the social and economic interests of rural Malays. It was founded in 1998 by an outspoken activist and long-time staff member of the (secular) Consumer Association of Penang (CAP), Mohamed 'Cikgu' Azmi Abdul Hamid. ${ }^{9}$ Instead of lobbying political leaders and lawmakers, the group has operated at the grassroots, particularly in poor, rural areas. Its programmes have been directed at developing, according to Cikgu Azmi, 'alternative modes of development' that can help people manage on their own. A primary example of the 'small-scale, counter-hegemonic tendencies within PAS' (Nagata 2010:29), and renowned (or infamous) for its harsh public criticism on Islamic feminists and their 'agenda to discredit Islamic practices' (Liow 2007:183), Teras has often been portrayed as a conservative group. Yet, its socio-economic programmes are rooted in an intellectual tradition that is anti-capitalist and leftist. According to Cikgu Azmi, a commitment to Islam may be seen as part of a cure for the inequalities in development and wealth spawned by the effects of a Western-style capitalist modernity. Asked about the extent to which he cherished democratic ideals to reach these goals, he stated: '[W] involve shura methodology... and democracy in that sense. But you know, I really hate that word [democracy]. I am not really comfortable with it.... We try to educate the people to understand the system, that the government should act in a more democratic way, and what corruption and abuse of power actually does to them. [The problem with the concept of democracy] is that it really is an alien thing that is given to us. Democracy puts too much emphasis on individualism. Individuals who are conditioned in such a modern living culminate into a vote that gives power to certain people, and that is not democratization.'

9 CAP was one of the seven organizations singled out by the Mahathir administration in its infamous crackdown on civil society, called operation Operasi Lalang, in 1987. 
While Islamic civil society leaders like Fadlulah Jamel and Cikgu Azmi spoke positively about the relative openness and cooperative stances that, in their view, characterized a multi-ethnic environment like Penang, with regard to the issue of religious freedom they were more ambiguous. 'I have my faith, you have yours,' Fadlulah said. 'Everyone should be allowed to practice his faith in freedom.' However, the autonomy of different ethnic groups should be protected by law, to such an extent that 'they [i.e. non-Muslims] do not expose themselves so that it threatens the stability, the morality of the people [i.e. Muslims].' The consumption of alcohol by non-Muslims, for example, was not a problem, as long as it did not 'bother' the Muslim community or infringed on their 'territory'. Making frequent references to Islamic history and the time of the Prophet, Fadlulah distinguished between 'friendly' non-Muslims - including the large majority of ethnic Chinese and Indian Malaysians who should be respected and who should have 'the right to education, proper food, proper homes, proper clothing' - and those 'who try to subjugate us, who try to change the system' (interview, 28 September 20o6).

Even more than Fadlulah Jamel's statements, the opinions of Cikgu Azmi seemed to illustrate the paradoxes at the heart of the dakwah movement and the political projects it has championed. On the one hand, he called for a change in thinking about politics and activism, associating the empowerment of the poor with a stronger adherence to Islam. On the other hand, his call was reserved, more or less exclusively, for Malays. In his view, Malaysia needed both a stronger enforcement of Islamic norms and support for Malay peasants. While critical about their implementation, he agreed with the government policies that have sought to address the socio-economic 'disparity' between the Malays and other ethnic groups. He did not distinguish, in this regard, between the Malay-majority states and Penang, which he regarded as 'firstly a Malay area.'

In fact, many dakwah adherents are products, one way or another, of the government's affirmative action programmes intended to educate Malays and increase their share in the Malaysian economy (Jomo 2004). Starting in the $1970 s$, increasing numbers of boys and girls from rural Malay families were selected by the state to study at institutions of tertiary education, where many of them were attracted to the dakwah movement's social criticism and religious ideology (see, for example, Muzaffar 1987; Nagata 1984; Shamsul 1997; Zainah Anwar 1987). While organizations like ABIM were critical of the government, their members also benefited from its social and economic programmes, the clearest indication of which, perhaps, is the fact that many (former) dakwah activists today are civil servants. As a result, they have not been very keen, generally, on criticizing the ethnicized model on which the Malaysian political 
system rests. In Malaysia, with its entrenched system of communal politics (rooted in the complex negotiations accompanying the decolonization process; see Harper 1998; Roff 1967), any discussion bearing on the relationship between Islam and citizenship should engage, one way or another, with the issue of ethnicity. While the dakwah movement takes a central place in the struggle for citizen rights, to make their voices heard, activists generally have complied with the racialized approach to politics that was cultivated by UMNO and the Barisan Nasional in the first place. Many of these groups - including those in a 'cosmopolitan' place like Penang - maintain a dakwah discourse that is, at its basis, Malay-centred and exclusivist. They bolster ethnic cleavages rather than transcend them.

The centrality of ethnicity in Malaysia's public debate and public policy explains, to some extent, why the call for the establishment of an Islamic state has met with more response in Malaysia than in Indonesia. The success of political Islam in Malaysia is often explained as a reaction by the 'secular' ruling party UMNO against the attacks of the Islamist opposition party PAs. However, as Liow (2009) has argued, the drive to strengthen Islamic law has been part and parcel of UMNO's attempt to secure the dominant (political and cultural) position of the Malays. Despite the sensitivity of the idea of an Islamic state, and regardless the fact that many state policies in the past decades have been directed at reducing ethnic tensions, the expanded jurisdictions of the religious courts and the generous support by the government for conservative religious institutions like JAKIM and JAWI seem to be a result, at least partly, of the view (disseminated by PAS and UMNO alike) that the cultural and religious traditions of the Malays are under permanent threat. In addition, religious discourses have served the expanding Malay middle class to defend their privileges vis-à-vis other ethnic groups (Hadiz and Khoo Boo Teik 2011). The effect of the dakwah movement - despite its call for particular civil rights (for example the right to demonstrate, to form an association, or the right to receive a fair trial) has contributed to rather than mitigated this dynamic and has deepened the entrenchment of an ethnicized model of citizenship in Malaysia.

\section{Citizenship and Tafsir}

Such debates about the nature and conceptualization of citizenship in Muslim Southeast Asia are contingent on another, underlying debate about how to approach and interpret religious texts. In general, we observe that the opposition to syariah legislation and the defence of minority rights and social tolerance does not, in most instances, rest on defending individual rights. Instead, they 
often focus on attempts to create space for different interpretations and to restrict the state in defining what is, and what is not, 'properly' Islamic. In many instances, the struggle for citizen rights, gender equality, minority rights, social tolerance and pluralism is waged in terms of hermeneutics and asbabulwurud, the need for developing contextual rather than literalist interpretations of religious prescriptions and injunctions and moral responsibility. This is not an abstract theological debate, but a lively discussion which bears directly on the ways in which people live their everyday lives.

Consider, for example, the activities of student organizations at university campuses. Groups like Formaci (Forum Mahasiswa Ciputat, an influential student group at the Islamic University Jakarta) and Jімм (Jaringan Intelektual Mudah Muhammadiyah, Network of Young Muhammadiyah Intellectuals) organize student meetings on hermeneutics and intertextuality, arguing that, in order to make Islam relevant for the present life, one should not simply adhere to a literal interpretation of the Quran or the hadith, but rather look at the intentions and the meanings behind these texts. As Formaci member Towik explains, 'the essence of Islam is justice. That is eternal. The text is just what is written at that time, so we need to get to the meaning of the text at that time.' These student activists take inspiration from Western hermeneutics and philosophers, like Jürgen Habermas, Jacques Lacan and Jaqcues Derrida, as well as Muslim thinkers such as Nasr Abu Zayd, Fazlur Rahman and Amina Wadud in order to substantiate the claim that there are no universal, 'objective' interpretations of texts and that the Quran and the hadith cannot be understood without practicing asbabul wurud, that is, without interpreting these texts in the context in which they originally appeared.

Attitudes of KAMMI students toward Islamic texts stand in sharp contrast with the opinions of Formaci students. In the last ten years, this has become the largest student organization in many universities. KAMMI can be seen as a branch of the tarbiyah movement, as most of its members take part in the same kind of religious instruction in small cells (although KAMMI activists call them likoh instead of usrah), which are led by senior students or outside instructors. An outspoken girl named Bila argues during an interview: 'The Quran is an everlasting book, so everything that is in there is still valid now. We do not believe in asbabul wurud. Everything about life can be found in the Quran. We need to adopt the Quran comprehensively. The law is created by God, not by humans, so we have to obey God's law.' How literally should the Quran be interpreted, then, as it takes contemporary forms of property like grain, gold or livestock as a condition for the obligation of zakat (alms)? 'These things can be translated into today's format,' she answers, 'by following Islamic jurisprudence $[f i g h]$ about it.' And the prison then, why not punish thieves by 
putting them in jail, instead of cutting off their hand? She shakes her head and says: 'Prison is a Western concept.'

Groups like KAMMI and kindred organizations like HTI and PKs have been presented as the agents of a 'conservative' turn in Indonesia (see, e.g., Van Bruinessen 2013). The drawback of such labels is that they tend to obscure the fact that these organizations seek to impose a form of Islam that was never the dominant norm in Southeast Asia. The forms of dress advocated by dakwah activists, for example, or the limited contact between the sexes are new, not old. And ideas about the way in which Indonesia should be governed - establishing an Islamic state, rejecting democracy and capitalism, implementing syariah law - are revolutionary rather than conservative. Similarly, labels like 'liberal' or 'progressive' have their drawbacks when describing the ideas expressed by organizations like Formaci. It is not a coincidence that many Formaci activists have a pesantren background. Traditional Islamic schooling, with its focus on the study of figh (Islamic jurisprudence), is a crucial basis for the view that Islamic texts can have numerous different interpretations and that they need to be interpreted in the context of the place and the society in which they originated. There is a decidedly conservative element to some of their thinking, for example when they defend the tradition of the wali songo, the nine saints who are believed to have Islamized Java, or the state philosophical doctrine of Pancasila, which accords legitimacy to five officially recognized religions but does not present religion as the main guiding principle of the state.

Instead, the terms 'scripturalist' and 'substantialist' (Bush 2009; Effendy 2003; see also Anwar 2007) come closer to what is at the core of these heated discussions, namely a basic difference of opinion regarding the question of how to approach and interpret religious texts, the Quran and hadith in particular. While scripturalists see these texts as direct messages from God, to humans living wherever and whenever, that need little interpretation, substantialists argue for a more flexible interpretation, encouraging Muslims to focus on the substance of Islam. Scripturalists argue for a literal implementation of all that is found in the Quran and hadith, including matters of corporal punishment, veiling, abolition of interest, apostacy and so forth. Since they do not interpret the fundamental texts in the light of the contexts in which they arouse or the context of present-day life, they feel that there are no exceptions regarding the Muslim duty to follow these commands. ${ }^{10}$ In their interpretation, Islam is basically a programme that needs to be implemented.

1o Because of this focus on the literal interpretation of texts, the terms 'legalistic' and 'formalistic' have also been proposed for this version of Islamic interpretation (Bush 2009:12). 
In contrast, substantialists (or 'contextualists') argue that one needs to interpret the Quran and hadith according to modern needs and circumstances in order to remain truthful to the 'substance' that is at the basis of these messages, meaning the core values and ideas propagated by Islam. This approach argues for the need of asbabul wurud: one should read the Quran in the light of the seventh-century Arabic context in which it was revealed to the Prophet. The injunctions and prescriptions in the Quran and hadith are specifically meant to deal with the problems of the present society, and cannot be expected to apply literally to a different society. A good example is the contentious issue of polygamy. In Indonesia, having up to four wives is allowed, except for civil servants. Although frowned upon by the general public, in recent years the practice has seemed to become increasingly popular, with men citing scripture in their defence. Critics, who typically argue that the practice is detrimental to the position of women, sometimes take a contextualist approach, arguing that Quranic references to polygamy reflect a historical intervention aimed at protecting children and widows in times of war and at regulating pre-Islamic practices of boundless polygamy (see Nurmila 2009).

The heated debates about Aceh's syariah laws are another example. Compared to the rest of Indonesia, Aceh has adopted the most elaborate and strict set of syariah laws, which are enforced (at least in theory) by a syariah police force (the Wilayatul Hisbah, or WH). ${ }^{11}$ Acehnese women rights' activists who take issue with these laws usually do not (or at least not squarely) direct themselves against the implementation of syariah law as such. Instead, they advocate alternative formulations that emphasize social justice, gender sensitive interpretations and the improvement of the living conditions of the Acehnese generally and women in particular. To this end, they organize study groups and seminars to educate themselves in matters of tafsir and ijtihad and engage on the basis of these skills and their knowledge of Islamic texts with male political and religious leaders to achieve, in the words of one activist, 'an Islam based on progressive concepts which will help to establish a tolerant, inclusive and modern environment compatible with democracy' (Kamaruzzaman 2004; see also Afrianty 2015; Großmann 2015; Jauhola 2013). Rather than invoking liberal conceptions of the inalienable rights of individuals, these debates revolve around interpreting classical Islamic jurisprudence and religious laws and their bearing on women's rights. In addition, local women's organizations have invoked the traditionally strong position of women in (rural) Acehnese society to educate women and challenge the assumed dominance by men over local

11 For an extensive discussion of Aceh's state syariah institutions, see Feener 2013. 
expressions of religious authority (Kloos, forthcoming 2016, Nurjannah Ismail 2003; Srimulyani 2015).

In this sense, the evolution of citizen rights and citizenship is bound up with changing attitudes toward religious texts. Indonesian and Malaysian organizations working on (human) rights are keenly aware of this, as an intense engagement with religious discourse plays an important role in their activities. Sometimes, this is purely for pragmatic reasons, as an open embrace of secular discourse can easily be construed (or wilfully framed) as an attack on Islam and as such be counter-productive. That has been the experience of JIL (Jaringan Islam Liberal, Liberal Islam Network). This organization was founded in 2001 to promote a liberal, moderate interpretation of Islam. Until 2005, the organization received funding from the Asia Foundation and the Ford foundation and with this support it started various activities, from airing videos to issuing books, organizing discussions, engaging with the media and starting a website (islamlib.com). Their activities provoked an angry response from scripturalist Islamic groups. When one of JIL's most public figures, Ulil Absar Abdalla, wrote in a national newspaper that 'there is no such thing as "the law of God...," only general universal principles,' he was declared an 'unbeliever' (kafir) and attacks on his life were allegedly being contemplated. Television channels refused to broadcast a short clip from JIL about the diversity within Islam after receiving threats from radical Islamist groups, and JIL came to be seen as a 'puppet of the west.' The provocative nature of JIL's statements may have been counter-productive. Some observers felt that their campaign helped 'conservative' forces within $\mathrm{NU}$ and Muhammadiyah to increase their support (see, for example, Fealy 2006). Furthermore, the opinions expressed by JIL came to be seen as 'Western' and 'against Islam,' instead of arising out of (contestations within) Islam. The acronym siphilis - for secularism, pluralism and liberalism - came into vogue, suggesting that these three 'isms' were a kind of illness inflicted by the West.

These experiences convinced other organizations that a more cautious engagement with religious discourse would be more successful (if this was not already their conviction). Take, for example, the activities of Rahima. This organization has been involved in organizing trainings and discussions with politicians, religious leaders and students organizations on such themes as gender equality, human rights and reproductive health. Yet, these terms have generally been avoided during Rahima's workshops, because they are perceived by many of their interlocutors as Western, secular impositions. As Ibu Edidani, the director of Rahima, explains, she looks for interpretations and words that connect better with prevalent worldviews. 'We do not use the word gender, but we talk about equality and fairness, and later about gender. And we do not 
use the word pluralism, we talk about diversity, using the word keragaman.' Rahima also does not talk about gender relations in terms of rights of women but rather in terms of mutual obligations. 'It would seem weird if we talk about "freedom" and "rights" when we talk about men and women, so we start with obligations. That is what people are more used to, and we try to expand it, by saying that as wives have obligations towards husbands, husbands also have obligations towards their wives.'

Tafsir, the exegesis of religious texts, is a core element of their discussions. 'Religion is a medium. We need to focus on the spirit of Islamic teaching. We take the principles and interpret it in our own way. They often work together with Kyai Hussein Muhammed from Fahmina - a similar organization in Cirebon - who developed a course with an elaborate curriculum on Islam and gender to spread more women-friendly interpretations of Islamic jurisprudence. ${ }^{12}$ During the course, Kyai Hussein emphasizes the contradictions and differences between the main schools of law (madhhab) to highlight his message that figh is not something divine but a product of human endeavour, and therefore needs to be constantly adapted in line with contemporary needs and circumstances. As he said during an interview, "There is nothing authentic in Islam. It is our duty to interpret what Muhammed said, and apply the hadith to make it work in today's life.'

This emphasis on tafsir and the (re)interpretation of religious texts as a means to defend women's rights is not unique to Indonesia. In Malaysia, the internationally renowned women's rights movement Sisters in Islam (SIS) champions the individual right to (re)interpret the Quran, work that 'feeds into our writing and press statements on contentious issues where the conservative religious authority or the Islamic movements are pushing for laws and policies that discriminate against women or violate fundamental liberties.'13 Formed in 1988 by a group of Muslim feminists working in the legal, journalistic and academic fields and committed to promoting the rights of women within the framework of Islam, sis has achieved considerable media attention, both inside and outside Malaysia. It has used this exposure to argue that both representatives of the government and the Islamist opposition have failed to read the fundamental sources of Islam in their contemporary societal context

12 See http://fahmina.or.id/en/islam-a-la-fahmina/dawrah-fiqh-concerning-women.html.

13 Nora Murat, 'Sisters in Islam: advocacy for change within the religious framework'. See http://www.whrnet.org/fundamentalisms/docs/doc-wsf-murat-sis-0311.rtf, (accessed 22 June 2007). 
(Zainah Anwar 2001). During the past two decades, the organization has been increasingly concerned with the encroachment of syariah institutions on women's rights through the step-by-step amendment of Islamic family law (see Othman, Zainah Anwar and Zaitun M. Kasim 2005). As Joseph Liow (2009:124) writes, this is an ironic development, 'given the fact that Malaysia once had the most progressive Islamic family law in the Muslim world, when it was first codified in 1984.' Responding to the case of Kartika Sari Dewi Shukarno and the caning of three women for syariah offenses in February 2010, the organization issued a press statement declaring that, besides violating international human rights and the 'constitutional guarantees of equality and non-discrimination,' the punishment betrayed a 'pre-Islamic understanding of justice and punishment in law' (Sisters in Islam 2010).

\section{Conclusions}

These debates about syariah legislation illustrate how the interpretation and realization of citizen rights in both Indonesia and Malaysia are closely bound up with the construction of religious discourse. A growing number of Islamic organizations have called for a more literalist interpretation of Islam's fundamental sources, and approaches the relationship between the state and its citizenships on this basis. Activists who disagree with this view, particularly those who have advocated gender equality, women's rights or social justice, often frame their campaigns in terms of a contextualized, or 'substantialist' interpretation of religious injunctions. At the same time, divergent approaches toward citizenship are based not only on the struggle about the 'correct' way of interpreting Islam, but also on very different conceptions of (human, women's, citizen, minority or individual) 'rights.' This becomes clear, for example, from the attempts by some Indonesian Islamists to design an alternative formulation of 'human rights,' freed from so-called 'Western' concepts of democracy and liberalism (Fealy 2008b).

In general, however, religious discourses and democratic or human rights discourses have been drawn into each other (Hefner 2011), producing complex opinions and convictions regarding the role of the state in protecting both the integrity of the Muslim community and individual freedoms. Our main argument has been that debates on citizenship and citizen rights in Muslim Southeast Asia are framed for an important part in religious terms, and shaped by evolving attitudes on how to approach and interpret Islamic norms and regulations. In Indonesia, and to a lesser extent also in Malaysia, these debates 
must be understood in the context of a fundamental contestation over moral authority, resulting, in turn, from processes of fragmentation (of authority), the emergence of new forms of religious authority and organization, as well as the blurring boundaries between state and religious institutions.

Citizenship in Malaysia and Indonesia is shaped, partly, by these religious debates. Malaysia, we have argued, went further in institutionalizing Islamic morality than Indonesia because of the role of Islam in legitimizing its differentiated, ethnicized citizenship regime. The call for an Islamic State has served, among others, a rising Malay middle class as an instrument to defend its privileged access to state resources vis-à-vis the country's (sizable) ethnic minorities. While many Malaysian dakwah organizations are part of a broader movement for citizen rights, their criticism of state authoritarianism has gone hand in hand, on many occasions, with the championing of the (special) rights and positions of the Malays. More generally, as Islamic organizations disseminating a 'scripturalist' approach are succeeding in enlarging the role of the state in enforcing religious morality, the rights of the individual are becoming more subservient to the perceived need to discipline a wider population on the basis of Islamic norms. In this sense, the evolution of attitudes toward religious law is generating a very different kind of separation between private and public in this part of the world, often at odds with liberal or secular values. In this light, we observed that most Islamic activist associations in Malaysia fall short of contributing to the formulation of a more inclusive concept of citizenship, which would require a breaking down of the institutionalized structures of ethnic politics.

While discourses focused on individual rights and religious freedom have served non-Muslims as a means to protest against discrimination, Muslim activism against political Islam and expansion of syariah law often takes the form of promoting a less scripturalist interpretation of Islam. Ironically, when progressive civil society organizations turn to Western donors for funding, in many cases their proposals are rife with secular discourse, while their intent is to organize activities directed at engaging with religious discourse. The reason for this is obvious. Western (typically secular) donor organizations do not see it their remit to fund the propagation of religious beliefs as they consider such support to be an intrusion into people's private sphere. Yet, a secular approach to propagating citizen rights in Indonesia and Malaysia risks touching only the surface of people's convictions and motivations, while possibly invoking the kind of aversion that JIL had to deal with. As we argued in this essay, Islam plays a key role in shaping interpretations of the 'proper' relation between citizens and the state in Malaysia and Indonesia. Therefore, traditional secular 
donors wishing to address these issues would do well to engage with debates taking place within Islam.

\section{References}

Afrianty, D. (2015). Local Women's NGOs and the Reform of Islamic law in Aceh: The Case of MISPI. In R.M. Feener, D. Kloos, \& A. Samuels (Eds.), Islam and the Limits of the State: Reconfigurations of Practice, Community and Authority in Contemporary Aceh (pp. 118-140). Leiden: Brill.

Anwar Ibrahim. (1996). The Asian Renaissance. Singapore: Times Books International. Anwar, M.S. (2007). The Clash of Religio-Political Thought. In T.N. Srinivasan (Ed.), The Future of Secularism (pp. 186-253). New Delhi: Oxford University Press.

Bakti, A.F. (2005). Islam and Modernity: Nurcholish Madjid's Interpretation of Civil Society, Pluralism, Secularization, and Democracy. Asian Journal of Social Science, 33(3), 486-505.

Beatty, A. (2009). A Shadow Falls: In the Heart of Java. London: Faber and Faber.

Bowen, J.R. (1996). 'Religion in the Proper Sense of the Word': Law and Civil Society in Islamicist Discourse. Anthropology Today, 12(4), 12-14.

Bowen, J.R. (2013). Contours of Sharia in Indonesia. In M. Künkler \& A. Stepan (Eds.), Democracy and Islam in Indonesia (pp. 149-167). New York: Columbia University Press.

Bubalo, A., \& Fealy, G. (2005). Joining the Caravan? The Middle East, Islamism and Indonesia. Alexandria, New South Wales: Longueville Media.

Buehler, M. (2008). The Rise of Shari'a Bylaws in Indonesian Districts: An Indication for Changing Patterns of Power Accumulation and Political Corruption. South East Asia Research, 16(2), 255-285.

Bush, R. (2009). Nahdlatul Ulama and the Struggle for Power within Islam and Politics in Indonesia. Singapore: ISEAS.

Effendy, B. (2003). Islam and the State in Indonesia. Singapore: ISEAS.

Eickelman, D.F., \& Piscatori, J.P. (1996). Muslim Politics. Princeton: Princeton University Press.

Esposito, J.L., \& Mogahed, D. (2007). Who Speaks for Islam? What a Billion Muslims Really Think. New York: Gallup Press.

Farish A. Noor. (2003). Blood, Sweat and Jihad: The Radicalization of the Political Discourse of the Pan-Malaysian Islamic Party (PAS) from 1982 Onwards. Contemporary Southeast Asia, 25(2), 200-232.

Farish A. Noor. (2010). On the Permanent Hajj: The Tablighi Jama'at in South East Asia. South East Asia Research, 18(4), 707-734. 
Farish A. Noor. (2014). The Malaysian Islamic Party PAS, 1951-2013: Islamism in a Mottled Nation. Amsterdam: Amsterdam University Press.

Fealy, G. (2006). A Conservative Turn. Inside Indonesia 87 (Juli/September).

Fealy, G. (2008a). Consuming Islam: Commodified Religion and Aspirational Pietism in Contemporary Indonesia. In G. Fealy \& S. White (Eds.), Expressing Islam: Religious Life and Politics in Indonesia (pp. 80-94). Singapore: ISEAS.

Fealy, G. (2008b). Indonesian Islamist Perspectives on Human Rights. In S. Akbarzadeh \& B. MacQueen (Eds.), Islam and Human Rights in Practice (pp. 142-153). London and New York: Routledge.

Fealy, G., \& White, S. (Eds.). (2008). Expressing Islam: Religious Life and Politics in Indonesia. Singapore: ISEAS.

Feener, R.M. (2013). Shari'a and Social Engineering: The Implementation of Islamic Law in Contemporary Aceh, Indonesia. Oxford: Oxford University Press.

Formichi, C. (2014). Violence, Sectarianism, and the Politics of Religion: Articulations of Anti-Shi'a Discourses in Indonesia. Indonesia, 98(1), 1-27.

Großmann, K. (2015). Women's Rights Activists and the Drafting Process of the Islamic Criminal Law Code (Qanun Jinayat). In R.M. Feener, D. Kloos, \& A. Samuels (Eds.), Islam and the Limits of the State: Reconfigurations of Practice, Community and Authority in Contemporary Aceh (pp. 87-117). Leiden: Brill.

Hadiz, V.R., \& Khoo Boo Teik. (2011). Approaching Islam and Politics from Political Economy: A Comparative Study of Indonesia and Malaysia. The Pacific Review, $24(4), 463-485$.

Hamayotsu, K. (2012). Once a Muslim, Always a Muslim: The Politics of State Enforcement of Syariah in Contemporary Malaysia. South East Asia Research, 2o(3), 399-421.

Harper, T.N. (1998). The End of Empire and the Making of Malaya. New York: Cambridge University Press.

Hefner, R.W. (1993). Islam, State, and Civil Society: ICMI and the Struggle for the Indonesian Middle Class. Indonesia, 56, 1-35.

Hefner, R.W. (200o). Civil Islam: Muslims and Democratization in Indonesia. Princeton: Princeton University Press.

Hefner, R.W. (2011). Human Rights and Democracy in Islam: The Indonesian Case in Global Perspective. In T. Banchoff \& R. Wuthnow (Eds.), Religion and the Global Politics of Human Rights (pp. 39-69). Oxford: Oxford University Press.

Hefner, R.W., \& Horvatich, P. (1997). Islam in an Era of Nation-states: Politics and Religious Renewal in Muslim Southeast Asia. Honolulu, HI: University of Hawai'i Press.

Herrera, L.A., \& Bayat, A. (Eds.). (2010). Being Young and Muslim: New Cultural Politics in the Global South and North. Oxford: Oxford University Press. 
Hicks, J. (2014). Heresy and Authority: Understanding the Turn Against Ahmadiyah in Indonesia. South East Asia Research, 22(3).

Hoesterey, J.B. (2015). Rebranding Islam: Piety, Prosperity, and a Self-help Guru. Stanford: Stanford University Press.

Hosen, N., \& Liow, J.C. (Eds.). (2010). Islam in Southeast Asia. Volume III. Betwixt Local and Global: Islamic Civil Society in Southeast Asia. London: Routledge.

Howell, J.D. (2008). Modulations of Active Piety: Professors and Televangelists as Promoters of Indonesian 'Sufisme'. In G. Fealy \& S. White (Eds.), Expressing Islam: Religious Life and Politics in Indonesia. (pp. 40-62). Singapore: ISEAS.

International Crisis Group. (2008). Indonesia: Implications of the Ahmadiyah Decree Asia Briefing No. 78. Jakarta/Brussels: International Crisis Group.

Jauhola, M. (2013). Post-Tsunami Reconstruction in Indonesia: Negotiating Normativity through Gender Mainstreaming Initiatives in Aceh. London: Routledge.

Jomo, K.S. (2004). The New Economic Policy and Inter-ethnic Relations in Malaysia. Geneva: UNRISD.

Kamaruzzaman, S. (2004). Women and Syariah in Aceh. Inside Indonesia, 79.

Kelly, P.F. (2003). Developing Dissent in Industrializing Localities: Civil Society in Penang and Batam. In A. Heryanto \& S.K. Mandal (Eds.), Challenging Authoritarianism in Southeast Asia: Comparing Indonesia and Malaysia (pp. 6o-9o). London and New York: RoutledgeCurzon.

Kitley, P. (2008). 'Playboy Indonesia' and the Media: Commerce and the Islamic Public Sphere on Trial in Indonesia. South East Asia Research, 16(1), 85-116.

Kloos, D. (2014). In the Name of Syariah? Vigilante Violence, Territoriality, and Moral Authority in Aceh, Indonesia. Indonesia, 98, 59-90.

Kloos, D. (2015). Sinning and Ethical Improvement in Contemporary Aceh. In R.M. Feener, D. Kloos, \& A. Samuels (Eds.), Islam and the Limits of the State: Reconfigurations of Practice, Community and Authority in Contemporary Aceh (pp. 56-86). Leiden: Brill.

Kloos, D. (Forthcoming 2016). Female Islamic Authority, Local Communities, and the State in Aceh, Indonesia. Asian Studies Review 40(4).

Kortteinen, T. (2008). Islamic Resurgence and the Ethnicization of the Malaysian State: The Case of Lina Joy. Sojourn, 23(2), 216-233.

Künkler, M., \& Stepan, A. (Eds.). (2013). Democracy and Islam in Indonesia. New York: Columbia University Press.

Liow, J.C. (2007). Political Islam in Malaysia: Legitimacy, Hegemony and Resistance. In A.J.S. Reid (Ed.), Islamic Legitimacy in a Plural Asia (pp. 167-187). London: Routledge.

Liow, J.C. (2009). Piety and Politics: Islamism in Contemporary Malaysia. New York: Oxford University Press. 
Mahmood, S. (2005). Politics of Piety: The Islamic Revival and the Feminist Subject. Princeton, NJ: Princeton University Press.

Mujiburrahman. (2013). The Politics of Shariah: The Struggle of the KPPSSI in South Sulawesi. In M.v. Bruinessen (Ed.), Contemporary Developments in Indonesian Islam: Explaining the 'Conservative Turn' (pp. 145-190). Singapore: ISEAS.

Muzaffar, C. (1987). Islamic Resurgence in Malaysia. Petaling Jaya: Fajar Bakti.

Nagata, J.A. (1984). The Reflowering of Malaysian Islam: Modern Religious Radicals and their Roots. Vancouver: University of British Columbia Press.

Nagata, J.A. (1996). The 'Rebirth' of a Modern Malay Muslim Woman. Asian Journal of Social Science, 24(1), 36-51.

Nagata, J.A. (2010). Authority and Democracy in Malaysian and Indonesian Islamic Movements. In J. Saravanamuttu (Ed.), Islam and Politics in Southeast Asia (pp. 18-44). New York: Routledge.

Norani Othman, Zainah Anwar, \& Zaitun Mohamed Kasim. (2005). Malaysia: Islamization, Muslim Politics and State Authoritarianism. In N. Othman (Ed.), Muslim Women and the Challenge of Islamic Extremism. Malaysia: Sisters in Islam. Petaling Jaya: Sisters in Islam (SIS).

Nurjannah Ismail. (2003). Perempuan dalam Pasungan: Bias Laki-laki dalam Penafsiran. Yogyakarta: Lembaga Kajian Islamdan Sosial (LKIS).

Nurmila, N. (2009). Women, Islam and Everyday Life: Renegotiating Polygamy in Indonesia. London: Routledge.

Peletz, M.G. (1997). 'Ordinary Muslims' and Muslim Resurgents in Contemporary Malaysia: Notes on an Ambivalent Relationship. In R.W. Hefner \& P. Horvatich (Eds.), Islam in an Era of Nation-States: Politics and Religious Renewal in Muslim Southeast Asia (pp. 231-273). Honolulu: University of Hawai'i Press.

Peletz, M.G. (2013). Malaysia's Syariah Judiciary as Global Assemblage: Islamization, Corporatization, and Other Transformations in Context. Comparative Studies in Society and History, 55(3), 603-633.

Robinson, F. (2008). Islamic Reform and Modernities in South Asia. Modern Asian Studies, 42(2-3), 259-281.

Roff, W.R. (1967). The Origins of Malay Nationalism. New Haven, Conn.: Yale University Press.

Rudnyckyj, D. (2010). Spiritual Economies: Islam, Globalization, and the Afterlife of Development. Ithaca: Cornell University Press.

Shamsul A.B. (1997). Identity Construction, Nation Formation, and Islamic Revivalism in Malayasia. In R.W. Hefner \& P. Horvatich (Eds.), Islam in an Era of Nation-States: Politics and Religious Renewal in Muslim Southeast Asia (pp. 207-227). Honolulu: University of Hawai'i Press.

Sidel, J.T. (2006). Riots, Pogroms, Jihad: Religious Violence in Indonesia. Ithaca, NY: Cornell University Press. 
Sisters in Islam. (2010). Sisters in Islam Condemns Caning of Three Muslim Women under Syariah Law. Press Statement, 17 February 2010.

Sloane, P. (1999). Islam, Modernity, and Entrepreneurship among the Malays. New York: St. Martin's Press.

Solahudin. (2011). NII sampai JI: Salafy Jihadisme di Indonesia. Depok: Komunitas Bambu.

Srimulyani, E. (2015). Teungku Inong Dayah: Female Religious Leaders in Contemporary Aceh. In R.M. Feener, D. Kloos, \& A. Samuels (Eds.), Islam and the Limits of the State: Reconfigurations of Practice, Community and Authority in Contemporary Aceh (pp. 141-165). Leiden: Brill.

Tan Pek Leng. (2005). The Penang, Malaysia Experiment in People, Private, and Public Partnerships: Process, Progress, and Procedures. Asia Pacific: Perspectives, 5(2), 29-43.

Taylor, C. (1989). Sources of the Self: The Making of the Modern Identity. Cambridge, MA: Harvard University Press.

Turner, B.S. (1997). Citizenship Studies: A General Theory. Citizenship studies, 1(1), 5-18. van Bruinessen, M. (Ed.). (2013). Contemporary Developments in Indonesian Islam: Explaining the 'Conservative Turn'. Singapore: ISEAS.

van Doorn-Harder, P.A. (2006). Women Shaping Islam: Indonesian Women Reading the Qur'an. Urbana, Ill.: University of Illinois Press.

Weintraub, A.N. (Ed.). (2011). Islam and Popular Culture in Indonesia and Malaysia. London: Routledge.

Wilson, I.D. (2008). As Long As It's Halal: Islamic Preman in Jakarta. In G. Fealy \& S. White (Eds.), Expressing Islam:Religious Life and Politics in Indonesia (pp. 192-211). Singapore: ISEAS.

Zainah Anwar. (1987). Islamic Revivalism in Malaysia: Dakwah among the Students. Petaling Jaya: Pelanduk.

Zainah Anwar. (2001). The Struggle for Women's Rights within the Religious Framework: The Experience of Sisters in Islam. In C. Barlow (Ed.), Modern Malaysia in the global economy: Political and Social Change in the 21st Century. London: Edward Elgar. 
978-90-04-32966-9

Downloaded from Brill.com $\odot 4 / 26 / 2023$ 12:50:28PM via free access 


\section{PART 3}

\section{Middle Classes Engaging the State}


978-90-04-32966-9

Downloaded from Brill.com $\odot 4 / 26 / 2023$ 12:50:28PM via free access 


\title{
Digital Media and Malaysia's Electoral Reform Movement
}

\author{
Merlyna Lim 1
}

On the sunny afternoon of April 28, 2012, more than 200,000 ${ }^{2}$ protesters hit the streets for the largest street demonstration in Malaysia in decades. The protest that day was held under the banner of Bersih 3.0, which is the third in a series of rallies that started in 2007 and reoccurred in 2011. Bersih, which is what the movement has been popularly called, comes from a Malay word that literally means 'clean'. It is a nickname for the Coalition for Free and Fair Elections attempting to reform the existing electoral system in Malaysia by addressing pervasive electoral misconducts to ensure a free, fair and 'clean' election. The first Bersih rally in 2007 was commonly attributed to the shift in political landscapes in the 2008 general election where the ruling coalition Barisan Nasional $(\mathrm{BN})^{3}$ failed to obtain two-thirds of the super majority for the first time since 1969. The third and the largest rally, Bersih 3.0 in 2012, was held a year before the 2013 general election. Accordingly, it can be credited not only for mobilizing the highest voter turnout in the Malaysian history, but also for the relative success of an oppositional coalition Pakatan Rakyat (PR). Although the ruling

1 Canada Research Chair in Digital Media and Global Network Society, School of Journalism and Communication, Carleton University, email: Merlyna.Lim@carleton.ca. The author wishes to thank the editors, Henk Schulte Nordholt, Laurens Bakker and Ward Berenschot for their invitation to participate in this edited volume. She also thanks Abidah Setyowati for intellectually stimulating post-dinner discussions that found their ways to enrich this chapter. Part of this chapter was completed while the author served as a visiting research professor with the Princeton University's Center for Information Technology Policy; she sincerely acknowledges this support.

2 The media's estimation of the number of protesters ranges from 150,000 to 250,000 while the organizer claimed up to 300,000 . Here, the author chose to use an estimate that was commonly used in media and independent reports.

3 Barisan National or BN, which means 'National Front', is the major coalition whose main players are the United Malays National Organization (UMNO), the Malaysian Chinese Association (MCA) and the Malaysian Indian Congress (MIC).

4 Pakatan Rakyat or PR (Malay), which means 'People's Pact or People's Alliance', is an informal Malaysian political coalition that was formed by the People's Justice Party (PKR), Democratic Action Party (DAP), and Pan-Malaysian Islamic Party (PAS) on April 1, 2008 following the twelfth Malaysian General Election. The Sarawak National Party (SNAP) officially joined the 
coalition still secured the majority of seats, the opposition was able to steal $50.87 \%$ of the popular vote.

Without offices, remunerated staff, or a bank account, the Bersih movement quickly spread all over urban areas of Malaysia. The only headquarters of the movement is its official website, www.bersih.org, and since its launch in 2006 Bersih has incorporated digital media as a backbone of its operation. Blogging and YouTube were two dominant digital platforms used during the 2007 rally. In the 2011 Bersih 2.0 rally, Facebook and Twitter were added to the repertoire and these two social media platforms continued to be predominantly used in 2012. More than 58,00o tweets under the \#bersih hashtag were circulated within six hours of Bersih protest on 28 April 2012. ${ }^{5}$ Another 300,000 tweets, 2,000 YouTube videos and nearly 300 relevant blogposts were posted online within 24 hours after the protest began. ${ }^{6}$ Bersih 3.0 is possibly one of the most recorded protest movements in the history of Malaysia. However, despite its impressive use of social media, the Bersih movement is hardly taken into account when discussing the role of networked technologies in social protests that are predominantly centred in the Middle East, Europe, and North America. This chapter is meant to fill the gap in the study of digital media and political protests not only in Malaysia and Southeast Asia but also Asia in general.

In recent years, mainly triggered by the 2011 Arab 'Spring' and the 2012 Occupy Movement, there has been an upsurge of academic literature devoted to studying the role of digital media in popular uprisings. Generally speaking, the debates have revolved around two opposing arguments, namely, those who strongly emphasize the role of the internet and social media behind the people's uprisings in Egypt, Tunisia, the United States and other countries (see Harb 2011; Howard and Hussain 2012; Joseph 2011; Rane and Salem 2012), and those who dismissed the role of social media technologies claiming its incidental role and argue that these mass protests would have happened without the technologies (see Gladwell 2010; York 2011; Morozov 2013). Combining

coalition on April 20, 2010 after being expelled from BN but only to quit a year later on May 6 , 2011. The coalition currently controls three state governments while in opposition to the ruling coalition, BN, at the federal level.

5 Based on the author's research. These tweets also include those with \#bersih3, \#bersihpic, \#bersihreport and \#bersihstories hashtags.

6 Based on the author's research. 
computational mapping ${ }^{7}$ and online as well as offline ethnography, ${ }^{8}$ this chapter offers a different perspective. Rather than emphasizing the revolutionary role of digital media or underestimating it, here the author chooses to examine and contextualize the role(s) of the internet and social media as being embedded into the contour of societal changes and transformations.

Social movements and activists have always appropriated media technologies and utilized them as part of their resistance. In the early twentieth century, anarchist movements in the United States appropriated print technologies. By 1979, Iranian revolutionaries made use of audiocassettes to mobilize popular movements against the Shah (Sreberny and Mohammadi 1994) and in 1984, an independent radio was utilized to counter the government narrative of propaganda in the first People Power in the Philippines (Brisbin 1988). Similarly, the Xerox-ed copies of controversial websites were utilized to disseminate an anti-Suharto sentiment in the 1998 student movement in Indonesia (Lim 2003, 2008). Insurgent movements would naturally embrace the medium that suits the people most. Historically, every single major wave of protests in Malaysia, too, is associated with lively alternative media. In early twentiethcentury Malaysia, Malay journalists, poets and essayists played important roles in radicalizing the Malay majority and developing an anti-colonial sentiment against the British Empire. In the 1998 Malaysian Reformasi, ${ }^{9}$ the opposition group made intensive use of online alternative news to contest the ruling regime. In twenty-first-century urban dissident such as the Bersih movement, digital media is just that.

In Malaysia, public demonstrations were rare. Not only were they not tolerated by the authorities, public displays of resistance such as marching on

7 The author's research took advantage of the availability of computational tools that allow the automatic analysis of online content by using software for automated content analysis (using and creating programmes that can monitor multiple digital sources, process massive amount of text, and identify and display patterns, the author could measure the popularity and concentration of various topics on Facebook, Twitter, and blogging data related to the Bersih movement) and spatial sensitive analysis (that is the author analysed discourses around Bersih 3.0 rally by geotagging the tweets collected during the time of protests).

8 This methodology involves 'hanging out' in both geographical and non-geographical spaces through participant observation in both online and offline settings and interviews.

9 Reformasi is a Malay word meaning 'reform' in English. Malaysian Reformasi movement refers to the movement that began in the wake of former Prime Minister Mahathir bin Mohammad's controversial dismissal of his deputy, Anwar Ibrahim, in September 1998. This movement called for social and political reforms that opposed Mahathir's 'cronyistic' responses to the financial crisis (O'Shannassy 2009). 
the streets, protesting and calling for reform, were also not acknowledged as a characteristic of the multi-ethnic, allegedly politically passive society. Did digital media alter these conditions? Has digital media transformed the Malaysians to be politically active? Has digital media influenced the notion of participation and citizenship among urban Malaysians, especially the youth? These questions are at the heart of this chapter.

In one of the earliest studies on the role of the internet in politics, Margolis and Resnick (2000) conclude that political uses of the internet have mirrored existing patterns of politics or 'politics as usual'. About this study, eleven years later, Neuman, Bimber and Hindman (2011:37) commented, 'Perhaps they spoke too soon.' In the last decade, we have witnessed how digital and mobile media have become increasingly integrated into political communication and information and waves of citizen mobilization. Changes in technology have not led to 'dramatic changes in the political psychology of the average citizen, but internet-facilitated changes in citizenship are numerous, subtle, conditional, and still evolving' (Neuman et al., 2011:37). While very little empirical work is available, there are good reasons to think that digital media, especially social media, may implicate broader forms of political participation such as civic engagement, lifestyle politics and citizen-directed advocacy, on a deeper level, especially among younger citizens (Bennett 1998).

When writing about new technologies, it is tempting to focus on the causal relationship between the technologies and the 'change' they cause and, subsequently, focus on the technologies as the pivotal driver of change. In this chapter, however, the author attempts to stay away from a technologically deterministic framework. In answering the central questions posed here, we need to situate the technology in its context. In examining the role(s) of digital media in the Bersih movement, it is imperative to consider digital media as societally shaped by social, cultural and political arrangements in which it operates and by the users who are urban middle class Malaysians. Digital media does not have an intrinsic power to change politics. What has changed are the ways in which people are networked and mobilized with and through media. Consequently, how people participate and engage with politics has changed, too. A rapid proliferation of digital media in Malaysia, especially in urban areas, hence, may transform not only ways in which Malaysians interact with each other, but also how they interact with the state and participate in politics.

To help contextualize the political uses of digital media in the Bersih movement, the following section offers a brief historical overview of the making of the internet in Malaysia and how the technology became entangled with political activism. 


\section{The Internet and Activism in Malaysia}

Malaysia gained access to the internet in the mid-199os and since then, the government invested enormously in the internet infrastructure, predominantly for economic reasons. The former Prime Minister Mahathir Mohamed enthusiastically promoted this technology and gave full support to the building of the Multimedia Super Corridor (MSC), a high tech business centre developed to support the country's leap into the information age. As of the beginning of January 2012, months prior to the Bersih 3.0 rally, Malaysia's broadband household penetration rate was $62.3 \%$ with 17,723 ,0oo internet users representing $61.7 \%$ of the population (Internet World Stats 2012), which grew tremendously from only 3.7 million in 2000 (Rahim and Pawanteh 2011:5). The impressive growth of internet users and continued expansion of the technological infrastructure is a testimony of Malaysia's government's serious commitment to advancing an economically prosperous high-tech nation and transforming the country into an information society (Bunnell 2004). The government, however, continues to feel ambivalent about political and social significances of the same technology and has always been torn between the desire to promote the internet and shield its citizens from being exposed to 'unwanted information'.

Dissimilar to traditional and mainstream media outlets, the internet is not scrutinized under official censorship. The Malaysian government was committed to un-censor cyberspace, and this is a pledge that contrasts sharply with the nation's tightly controlled print and broadcast media outlets. The Bill of Guarantees of the MSC in 1997 indeed promises uncensored internet and this is also supported by a provision of the Communication and Media Act (CMA) in 1998 that explicitly states that nothing in the Act 'shall be construed as permitting the censorship of the internet' (Article 3). In practice, however, the internet is not free. The government can always use other media-related and libel laws such as the 1960 Internal Security Act, 1967 Police Act, 1966 Societies Act, 1971 Sedition Act, 1972 Official Secrets Act and 1984 Printing Presses and Publication Act against any parties who have different voices than the authorities. When alternative information sources such as the online news site Malaysiaki$n i$ found a way around the licensing regulations, the government reacted with various political threats such as preventing its journalists from getting official press cards and posing verbal intimidation and harassment against its reporters (Crispin 2013). In 2008, Raja Petra Kamaruddin, blogger and editor of the online news site Malaysia Today, was charged under the Sedition Act (Weiss 2014). In March 2009, six bloggers were arrested under the Communication and Media Act for criticizing the Sultan of Perak, one of the nine Malay rulers 
(Rahim and Pawenteh 2011:7). In 2012, a blogger by the name of Syed Abdullah Syed Hussein al-Attas was detained under the Official Secrets Act over a series of postings about the sultan of the Johor state (Crispin 2013).

Politics counts as a small portion of information exchanges online. Unsurprisingly, the internet in Malaysia is mostly used for social and personal use. A 2010 survey shows that with an average 233 online friends, Malaysian social media users were among the most social in the world (TNS 2010) and they spent an average of two thousand us dollar per person online each year. More than forty percent of Malaysian internet users access TV and movie content online, eighty percent access online streaming video content, and eighty-six percent download music regularly (SDMA 2012). Having said that, politics has its space in the Malaysian online sphere and online activism has a long history in the Malaysian political landscape.

Online activism in the country can be traced back to the use of the internet in the 1998 Reformasi movement. Given the control on mainstream media, in 1998 the internet became the principal means of communication among activists and an alternative source of information and news for Malaysians (Abbott 2004). Although the Reformasi movement did not lead to any substantial change in the 1999 elections, it gave birth to the Malaysia's online activism and rejuvenated civil society activism in the country (Abbott 2004; Weiss 2012). One of its legacies is the country's most progressive and powerful alternative online media, the Malaysiakini, a news site founded by two former mainstream journalists and closely associated with the Reformasi. Founded by writer-activists Pramesh Chandran and Steven Gan in November 1999, it survived the financial struggle and managed to establish a firm base in the Malaysian media landscape. Malaysiakini was ranked the fourteenth most visited website in Malaysia in March 2014, while the pro-government Star Online ranked fifteenth. ${ }^{10} \mathrm{An}$ other prominent alternative online media is Harakah Daily, an online version of the print Harakah, news outlet/tabloid of the oppositional party, Parti Islam seMalaysia (PAS). Also founded during the Reformasi, Harakah Daily quickly became the most sophisticated and content-rich partisan website and the first to include video (Downing 2010). Other prominent alternative online media include aliran.com, a website of Penang based NGO, suaram.net, belonging to the country's most vigorous human rights NGO, and various websites of Hindraf (Hindu Rights Action Force), a coalition of NGOs who advocate on behalf of Malaysia's (largely Hindu) Indian community (Pandi 2014).

With the imprisonment of Anwar Ibrahim, the leader of the Reformasi movement (who was later released in 2005), the opposition network disappeared

10 Extracted by the author from alexa.com's data. 
from the streets in early 2000. The decline of Reformasi as a political force, however, did not coincide with the decline of online activism. By early 2000, Reformasi no longer existed as an active movement, but its spirit of reform continued to exist in the online realm. Pro-reform activists continued using the digital media space as their subaltern counter-public space, an alternative space to the dominant bourgeois public sphere (Lim 2014), to cultivate socalled 'hidden transcripts' to communicate, deliberate, post and spread information online. Borrowed from James Scott (1990), 'hidden transcript' is a term for the critique of power that takes place offstage that cannot be seen or heard by power holders. The early vibrant alternative online media sphere paved the way for the emergence of the blogosphere activism in 2002 (Pandi 2011:77) and provided the basis and ingredients for the making of the Bersih movement in 2007 and its remaking in 2010 and 2012. Arguably, two decades of Malaysian online and offline activism since the late 199os provided an affordance for the relative success of the present-day Bersih movement.

\section{Bersih Movement}

To understand the Bersih movement we need to revisit its background story which is the story of the world's longest ruling coalition, the National Front or Barisan Nasional (BN). The Barisan Nasional is comprised of fourteen political parties led by the United Malays National Organisation (UMNO), the world's longest ruling party. The Barisan Nasional bases its political legitimacy on outstanding economic performance and popular sovereignty gained from winning the majority of electoral votes, even though multiparty elections were far from being fully free or fair (Weiss 2012:8). While the Barisan Nasional represents the ruling coalition, UMNO has continually been the ruling party in the country by holding the offices of prime minister and deputy minister since 1957 (Lee 2007). Consequently, the culture of the Barisan Nasional's governance reflects much of UMNO's preferences. As scripted in its constitution, UMNO bases its political ideology on Malay nationalism that guarantees, among others, the position of the Malay language as the sole national language and a Malay culture as a national culture as well as the rights of the Malays or bumiputra ('sons of the soil') (Lee 2007). Accordingly, in each and every election, the Barisan Nasional benefited from the demographics as UMNO has been seen as the protector of Malay interests with Malays compromising over half of the total population.

In the 2004 Elections, BN's performance was strong. It gained $64 \%$ of the popular votes and won 198 parliamentary seats. Under the Barisan Nasional's leadership, Malaysia's economic development had been outstanding, elevating 
the country's status from a developing one to an upper middle-income state (World Bank 2012). The middle-class population is growing rapidly, and economically Malaysia is on track to achieve a 'fully developed nation' status as outlined in the Prime Minister Mahathir Mohamed's Vision 2020 plan. Its economic development, however, is not accompanied by political change. The Malaysian government selectively pushed transparency and 'good governance' to deliver necessary and essential information to be accountable to international capital, but not to its citizens (Rodan 2005).

The Bersih movement is meant to push for changes in politics with electoral reform as the first milestone. A more popular name for the Coalition for Clean and Fair Elections, Bersih is an alliance of sixty-two non-governmental organizations (NGOs) seeking to reform the national electoral system. It started out as a Join Action Committee for Electoral Reform formed in July 2005 which was officially launched on 23 November 2006 as a joint communication network that comprised of leaders from various political parties, civil society groups and NGOs.

The call of Bersih can be summarized in eight points ${ }^{11}$ :

1. Clean the electoral roll from irregularities such as gerrymandering and 'phantom voters';

2. Reform the postal ballot to ensure that all citizens are able to exercise their right to vote;

3. Use of indelible ink;

4. Free and fair access to media;

5. Minimum 21 days campaign period;

6. Strengthen public institutions; they must be reformed to act independently, uphold laws, and protect human rights;

7. Stop corruption;

8. Stop 'dirty' politics.

As clearly expressed in these eight points, from the beginning the movement has had a clear set of targets that were well defined and far from abstraction, especially when compared with most political movements that have emerged globally in recent years. The first five points are translatable into practices. While less practical, the last three nevertheless represent tangible and actionable targets. This is distinctive from other movements calling for 'reform' such as the Occupy Wall Street and Spanish Indignados in which the goals were

11 The first four points were put forward in 2007; the others were added in 2011 (see http:// www.bersih.org/?page_id = 4109). 
vaguely defined. Also, unlike recent uprisings in the Arab world, the Bersih movement, at least until the third rally, was not about overthrowing a regime. ${ }^{22}$ As observed by Weiss (2007), the trajectory of reformism in Malaysia's 'competitive electoral authoritarian' system indeed tends to take an 'electoral route' rather than regime change.

Bersih's journey has been historic. Its first public demonstration was held on 10 November 2007 in Kuala Lumpur and estimated to have drawn 30,00050,000 supporters. As stated previously, this rally was frequently credited for the shrinking support for the ruling coalition in the 2008 general election where for the first time in nearly four decades the ruling coalition failed to obtain two-thirds of the super majority. In November 2007, the appearance of thousands of ordinary Malaysians rallying on the streets surprised the government. As mentioned earlier, public protests were a rarity in Malaysia. In 1998-1999 there were some sparks of street activism with the emergence of the Reformasi movement, but the authorities successfully cracked them down. Since 200o, the Malaysian streets had become sterile, apolitical. Except for the anti-Iraq protests in 2003, there was no major protest that took place in the period 2000 to 2006.

In April 2010, the coalition was relaunched as an entirely civil society movement unaffiliated with any political party. On 19 June 2011, former president of the Bar Council, Ambiga Sreenevasan, became the chairperson of the coalition. In 2011 and 2012, two more rallies, Bersih 2.0 and Bersih 3.0, were organized considering that the demand for the electoral reform had not been met by the Electoral Commission in 2008. Despite being considered illegal by the government which combated the protesters with the riot squad, tear gas and street arrests, Bersih 2.0 in July 2011 still drew a crowd of about 50,000 protesters. The 2012 Bersih 3.0 rally brought together even more supporters. The ban on using the centrally located Dataran Merdeka (Independence Square), road blockages, riot police, tear gas, and water cannons coloured the rally that was estimated to have drawn more than 200,000 supporters.

In the face of the government's persistent crackdown and criminalization, the Bersih movement became increasingly popular and a significant social and political force in Malaysia. More than just a movement pushing for electoral reforms, the Bersih also contributed to an increased level of political awareness among urban Malaysians, especially the youth. Consequently, with more than

12 This chapter was written before the fourth rally, Bersih 4.o., took place in August 2015 and, therefore, this rally does not form part of the study. It is important to note, however, that Bersih 4.0 indicated a significant change, as it demanded the resignation of the prime minister, Najib Razak. 
ten million casting their ballots, voter turnout in the 2013 General Election was at an all-time high. But what was more important was that Barisan Nasional, while having secured a majority of seats of $60 \%$ and thus the chosen agent to form the federal government, only gained a mere $47.38 \%$ of the popular vote. In contrast, the oppositional coalition, Pakatan Rakyat, won with 50.87\%. For Barisan Nasional, this was the worst election result since 1969 .

The use of digital media for political activism in the context of Malaysia should also be read vis-à-vis the government's control over public gathering in physical spaces. While the constitution granted freedom of assembly and association, it also allowed restrictions deemed necessary in the interest of security, public order, or morality, particularly through the use of the Public Order Ordinance and the Police Act (until 2013). This act defined a public assembly as a gathering of five or more persons. The decision to grant or deny a permit came from the district police chief. However, senior police officials and political leaders influenced the granting or denial of some permits. Police granted permits routinely to government and ruling coalition supporters but used a more restrictive approach with government critics, opposition parties, NGOS and human rights activists (BDHRL 2011). With such restrictions, mobilizing public protest was extremely discouraged. In 2013, Section 27 of this act was replaced by the new act, the 2012 Peaceful Assembly Act (PAA), which voids the police permits for mass assemblies. The PAA, however, comes with 'new' restrictions and is perceived by its critics as actually more restrictive that the previous act. The old-style method used by the opposition to mobilize its supporters was the organization of the ubiquitous indoor meeting or ceramah (Lee 2007:41). But besides having limited reach, ceramah required a police permit. It was due to the difficulties of finding a suitable physical space to gather and organize themselves that Bersih activists turned to digital space. There, they mobilized their supporters and prepared the rallies, thereby expanding and sustaining the movement.

\section{Bersih's Usages of Digital Media}

To understand the various roles of the so-called 'new media' or 'digital media' in the Bersih movement it is necessary to look beyond these umbrella terms. Instead of treating 'digital media', 'the internet' and or 'social media' as monolithic, I here examine the usage of three dominant platforms individually: blogging, Facebook and Twitter. ${ }^{13}$ By doing so, I attempt to understand the actual

13 While they are not discussed here individually, the author does recognizes the importance of YouTube and Flickr. In Bersih-related activities, however, these platforms were 
practices rather than the assumed practices of media and technology as sociomaterial artefacts.

Blogging plays an important part in the history of Bersih, especially in its early establishment. The 2007 Bersih rally was largely socialized and mobilized online, by using websites and blogs. This coincided with the peak of the blogging popularity in Malaysia. ${ }^{14}$ From 2002 to 2007, the blogosphere was both a vital space for online dissidents as well as the place where the Malaysian government exercised hegemonic power. Despite the government's crackdown and arrest of blogger activists, the Malaysian blogosphere continued to be politically vibrant. By 2007, the Malaysian blogosphere had developed, presenting new opportunities for citizen activism. The blogosphere facilitated activists to discuss and identify the 'repertoire of contention' (Tilly 2003), which refers to the set of various protest-related tools and actions available to a movement, and to identify issues that were important to the public.

The Bersih movement itself was partially born out of social interaction within the Malaysian political blogosphere. Years of political conversations in the blogosphere - by posting, reading and commenting - had enabled a 'brokerage' (McAdam, Tarrow and Tilly 2001) that allowed people to organize and assimilate their experiences, and deliberate across existing political boundaries. Blogging arguably brought together otherwise disconnected Malaysian activists and concerned individuals with different ideologies (Islamist, secular, liberal, et cetera) and backgrounds (Malay, Chinese, Tamil/Indian, et cetera), thus contributing to the expansion of the network of activists who believed in political reform.

The Bersih movement made use of blogs before, during and after the protests. An official website and blogs were used in particular to amplify and extend traditional communication efforts in a conventional mode of action (such as press releases). Blogs were used to mobilize campaigns and to provide reports from the streets countering state-controlled media interpretations of the protests and capitalizing on any conflicts or incidents that occurred in the protests (such as arrests or abuse). One such instance happened days after the Bersih 2.0 rally in July 2011 when Datuk Seri Hishammuddin Hussein, the home

generally used as placeholders, though most popular YouTube videos could generate voluminous comments on videos and photos, some of which were subsequently disseminated through blogs, Facebook and Twitter.

14 Most Malaysian blogs were not political, but many top bloggers were. A 2007 survey by sabahan.com (2007) identified eight out of Malaysia's top fifty bloggers as political bloggers. 'Screenshots', the blog by Jeff Ooi (an independent journalist who was also associated with the Malaysiakini daily and who ranked fourth on the above mentioned list) was the most popular among the political blogs, followed by media activist Ahirudin Attan's 'Rocky's Bru' and DAP leader Lim Kit Siang's blogs. 
minister, released a statement that there was no incident of 'police brutality' and that action would be taken against online media and bloggers if they posted false reports. Despite the threat, numerous bloggers responded to this statement by contemporaneously posting photos and YouTube videos displaying the 'brutality' of riot police. By doing so, they successfully countered the government's narrative as reflected in the coverage of the Bersih 2.0 rally by the mainstream media who described the Bersih movement as 'illegal' and its protesters as 'rioters'. And they were triumphant in generating public sympathy and support.

Blogs enabled the inner-circle of blogger-activists, a closely-knit cluster of activists, to deliberate on important issues that went beyond mere mobilization. The emerging blogosphere presented oppositional activists with a space where they could construct meaning for the movements' participants. The symbiosis between activists and the blogosphere resulted in a new form of engagement in an online civic space that was both subversive and empowering to the reformist activists.

\section{Bridging Diverse Publics through Facebook}

With the popularity of social media in 2008 , the Bersih movement started incorporating YouTube and Facebook into its communication and mobilization strategy. In the blogosphere, social-political bloggers in Malaysia connected mostly with each other. Blogging is useful for nurturing intimate relationships within certain social circles, but it is limited in its capacity to diffuse information and grow networks. Facebook, however, allowed them to simultaneously connect with their large social networks. Facebook's infrastructure, on the other hand, revolves around 'involuntary and radical transparency' allowing conversations to happen on one-to-one, one-to-many, and many-to-many levels, making it easy to diffuse information in multiple overlapping networks and to mobilize across diverse publics (Lim 2013:642) ${ }^{15}$ Such 'forced transparency easily leads to forced conformity as it generates peer pressure among interconnected users' (Lim 2013:642).

Facebook's infrastructure encourages effortless sharing, joining and interacting. For typical Malaysian users who, on average, have more than two hundred 'friends' in her/his network (TNS 2010), Facebook enables the rise and expansion of weak-tie networks to 'unlock and expose interpersonal networks to external influences [from] individuals in distant networks' (Goldenberg, Libai and Muller 2001:21), thus facilitating the spread of information to the

15 In contrast to what it promotes, Facebook as a company is far from being transparent, especially in its treatment of individual data and users' privacy. 
masses. The combination of forced transparency and conformity, highly accessible participation and interaction, and easy expansion of weak-tie networks often leads to the superficiality of Facebook-based collective actions, leading to the emergence of online activism that usually is 'too thin, too fast, too many' (Lim 2013:653). In the Bersih case, however, this combination turned out to be a valuable resource as it facilitates the linking of individuals from different social groups, bridging the diverse public in interconnected conversations. This can potentially facilitate the emergence of communities that transcend boundaries of ethnicity and religion, opening possibilities for 'bridging socio-political cleavages' (Weiss 2012:26). Indeed, both Bersih 2.0 and Bersih 3.0 rallies exemplify a successful mobilization across such cleavages. Relying heavily on Facebook for its mobilization, the 2012 Bersih rally brought a diverse mix of about 200,000 Malaysians to the streets of Kuala Lumpur.

The official Facebook page of Bersih 2.0 titled 'Bersih 2.0 [Official]'16 was created only seventeen days before the rally day on 22 June 2011. It functioned as central news desk where Bersih supporters posted, and checked for updates, announcements, photos and videos. Facebook continued to be one of the organizing and mobilizing tools in the Bersih 3.0 movement. Unlike blogging, Facebook is not a suitable platform for rigorous conversations and in-depth deliberations, but it does allows for a quick deliberation on simple issues. For example, when the Bersih activists' requested to use Merdeka Stadium for the rally, it was rejected by the Merdeka Heritage Trust (a trust set up by the Malaysian government to manage two stadiums, Merdeka Stadium and Stadium Negara, as national real estate heritage). The rejection letter was posted on Facebook to solicit quick comments. It quickly generated 344 'likes' and 221 comments nearly all suggesting to take the Bersih rally to the streets and stick with the original plan. Bersih organizers responded to this request by creating a simple poll with the question: 'Do you think a Bersih 2.0 public assembly should be organized?' More than half of the voters answered affirmatively $(101,345$ versus 89,040$)$. This kind of public decision-making process through Facebook did occur quite frequently. Further, Facebook is particularly useful for discussions and preparations ahead of the rally. On Facebook, Bersih users discussed protest sites and locations for gathering prior to marching to the protest site. They shared maps, directions and other information about the locations.

16 After the Bersih 2.0 rally, the Bersih movement maintains its existence on Facebook by establishing Bersih 3.0 as well as Bersih 4.o pages. The latter was meant to support the future, fourth Bersih rally. The first and 'official' Bersih 2.o Facebook page, though, remains the most popular one. 


\section{Twitter: Seamless Linking of Digital and Urban Spaces}

Twitter started to be utilized in the Bersih 2.0 rally and its usage was highly intensified in Bersih 3.o. Unlike Facebook, which was mostly used before and after the protest, Twitter was especially used during the protest largely to provide on-the-ground updates (see Figure 9.1). Protesters and organizers sent tweets on where to go, where to avoid riot police, places where tear gas and water cannon were deployed and incidents of arrest. Many tweets came with links to images and YouTube videos taken on the streets. During the Bersih 2.o rally, over 19,00o Twitter users tweeted about the rally that day (Sheriff 2011), in the Bersih 3.0 rally the number increased to over 300,000. Within six hours alone, from one p.m. to seven p.m. on the rally day, 28 April 2012, there were over 58 ,00o tweets using \#Bersih-related hashtags transmitted online.

Twitter, to a certain degree, helped to globalize the movement. The pattern of Twitter usage shows that Bersih-related tweets came from all over the world (see Figure 9.2). However, unlike the Arab Spring, when the majority of tweets came from a global, mostly Western, audience, ${ }^{17}$ in the Bersih 3.0 case, the majority of tweets - sixty-seven percent of the geotagged tweets - come from Malaysia, with a high concentration of tweets in Kuala Lumpur, Johor Baru and Penang (see Figure 9.3). A closer look at the geotagging map shows that

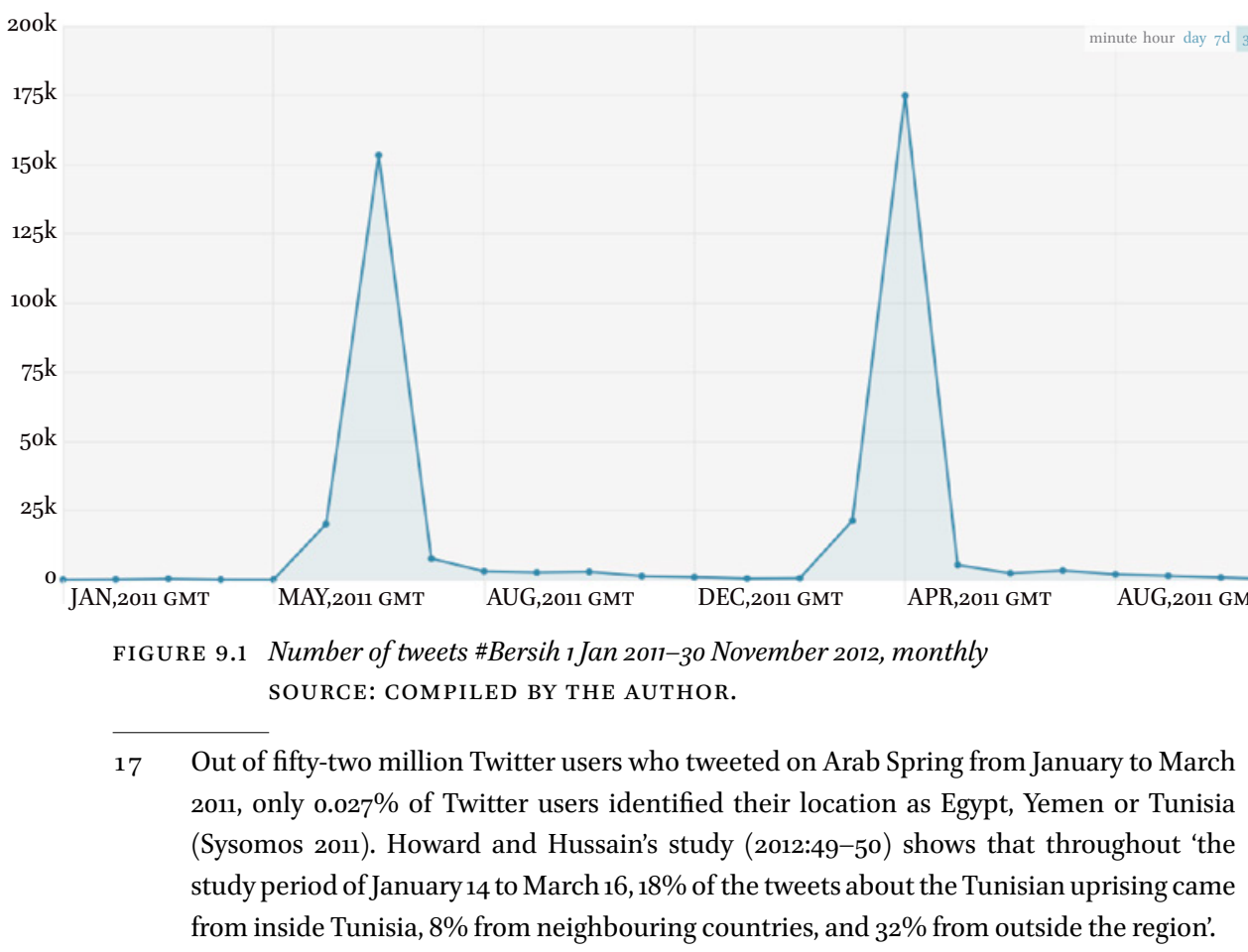




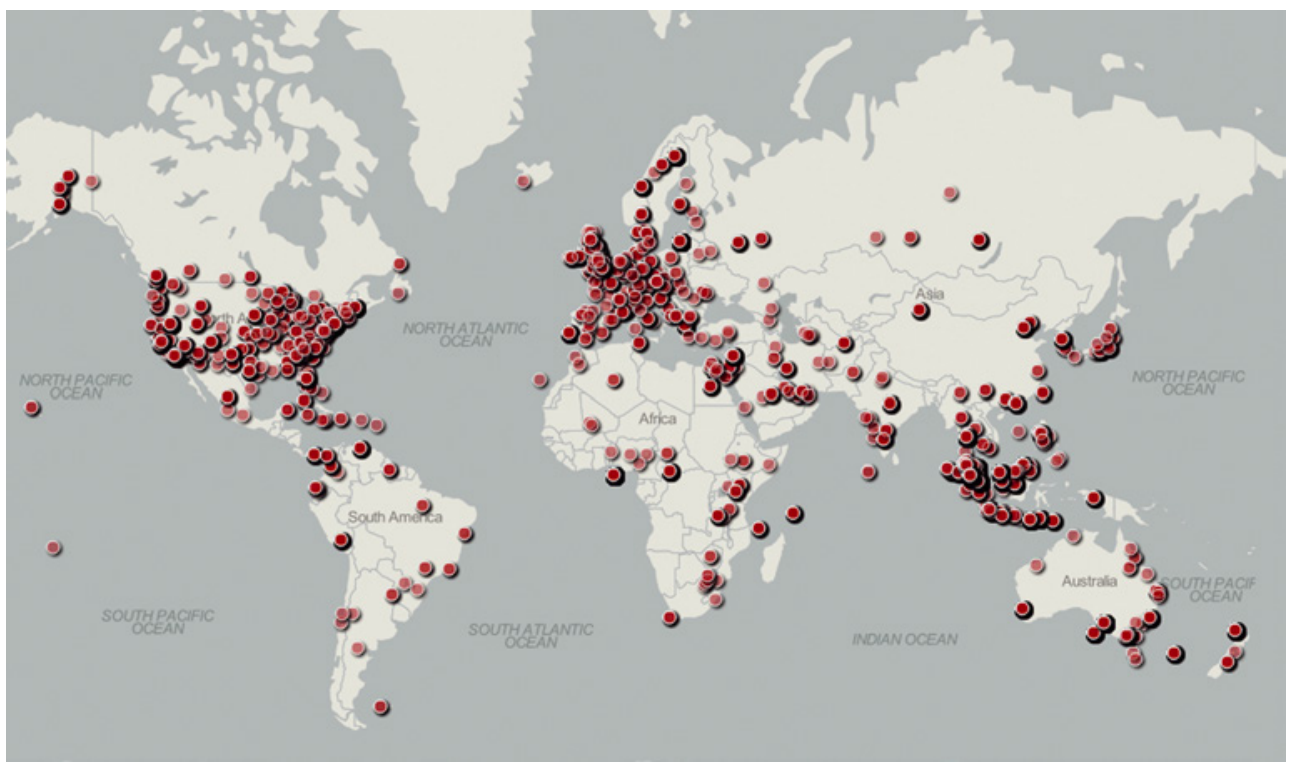

FIGURE 9.2 Global map of Bersih tweets, 28 April 2012, 01:00-7:00 P.M. SOURCE: COMPILED BY THE AUTHOR.

central Kuala Lumpur generated the highest number of tweets, especially in areas where the supporters gathered and protested, such as around Merdeka Square, the Jamek mosque, the Sultan Abdul Samad building, the Strait Trading building, Pasar Seni, Jalan Raja and Jalan Tun Perak (see Figure 9.4).

Twitter was heavily used during the protest to exchange information about locations. Among the most frequently used words are names of locations such as Merdeka Square and the Jamek mosque, and references to place-based activities and atmospheres/situations such as walk to, escape, run from, turn right or turn around. Bersih protesters can easily use Twitter on their smart phones, and it is through this medium that digital and physical activism and urban spaces have begun to interlock.

Twitter was also used to render conflicts visible, thereby globalizing the space of conflict. This visibility of conflicts is archetypal to the capacity of social movements to appropriate spaces of hegemonic production of visibility' (Starr, Fernandez and Scholl 2011:27). Through the Royal Malaysia Police (Police Diraja Malaysia) communication channel, the Malaysian government kept trying to portray Bersih protesters as 'unclean' rioters and law-breakers, and the movement as illegal. By using Twitter, Bersih protesters delivered a counter-narrative, as they uploaded their own images and YouTube videos. Through Twitter, the movement became associated globally with imageries 


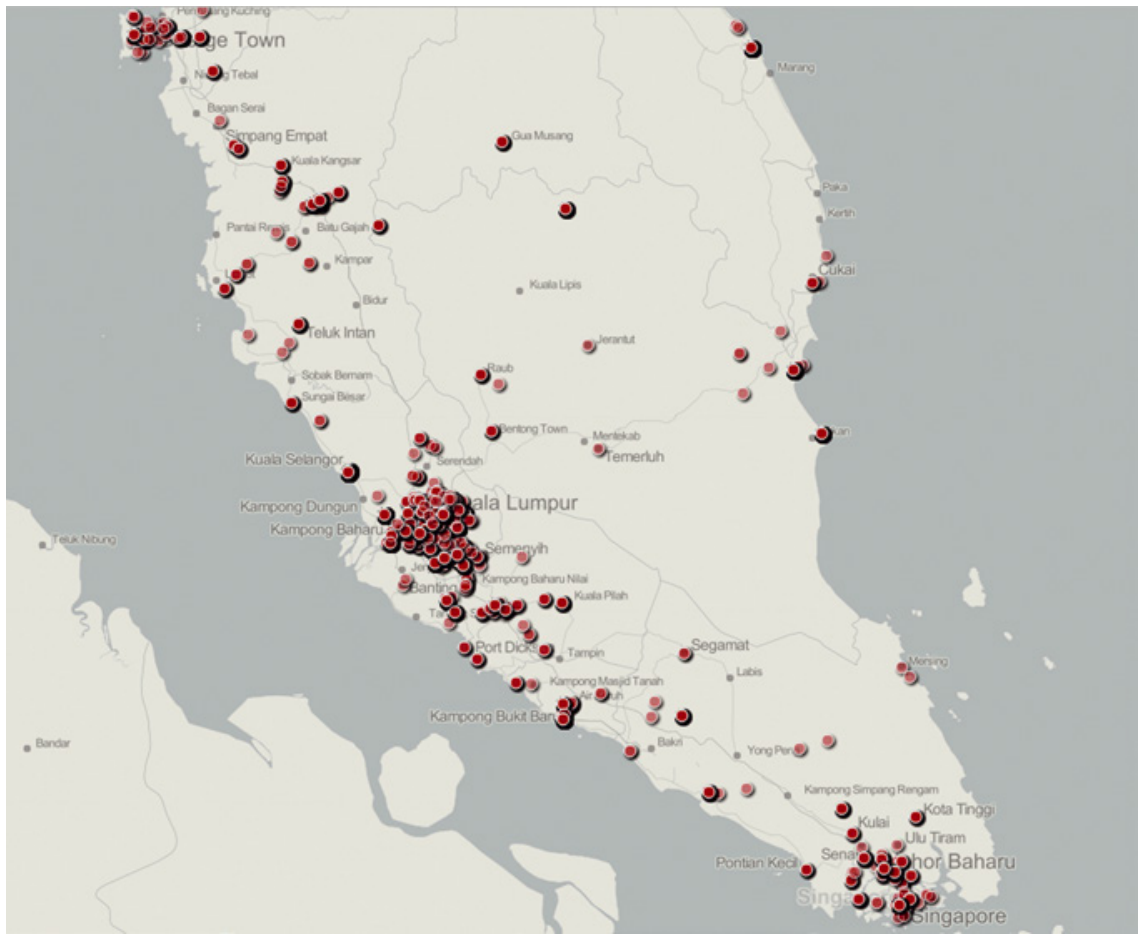

FIGURE 9.3 Kuala Lumpur, Johor Baru and Penang map of Bersih tweets, 28 April 2012, 01:00-7:00 P.M.

SOURCE: COMPILED BY THE AUTHOR.

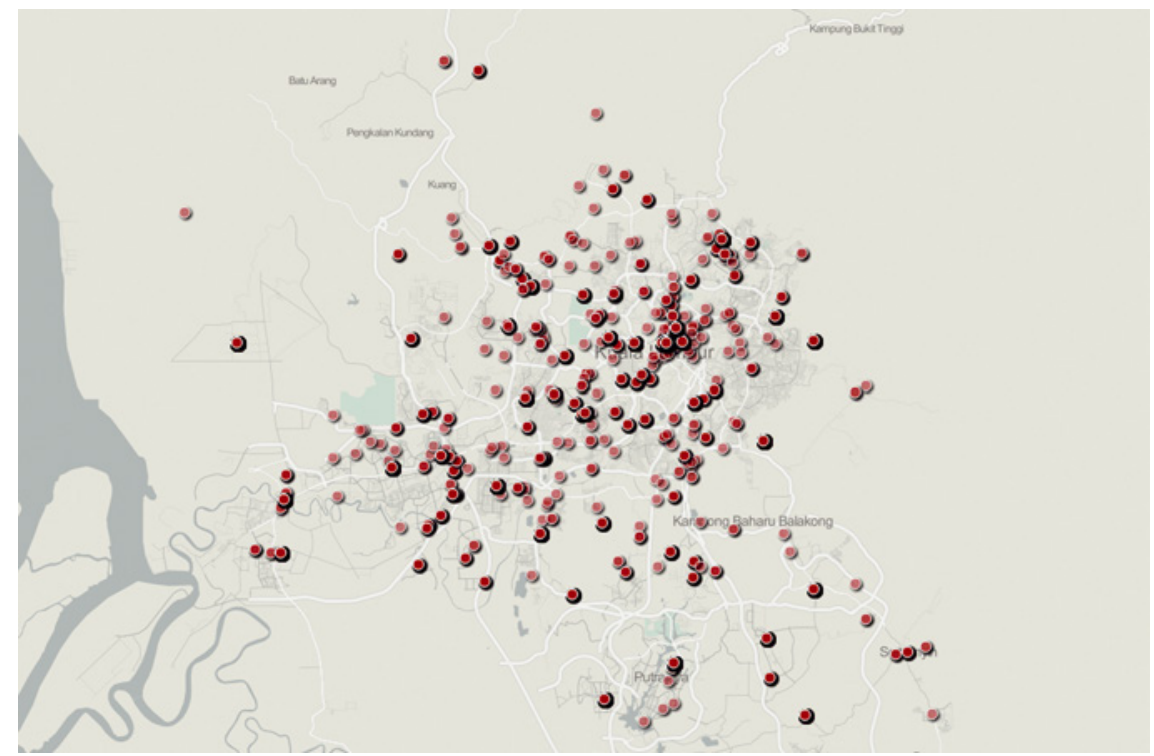

FIGURE 9.4 Central Kuala Lumpur map of Bersih tweets, 28 April 2012, 01:00-7:00 P.M. SOURCE: COMPILED BY THE AUTHOR. 
of mass protests in the streets, including blockages, tear gas, skirmishes and police violence. This tactic turned out quite effective. It faced the government with the dilemma of how to control these challenges to its legitimacy without giving the impression of 'un-democratic' governance.

\section{Opposing \#Bersih: The State/Ruling Coalition's Usage of Digital Media}

The internet and social media are 'convivial' (Lim 2003:274), and as such they provide 'a greater scope for freedom, autonomy, creativity and collaboration' than 'older' media such as telephony and television (Lim and Kann 2008:82). But it is not just the reformists who took advantage of these digital tools; their opponents did too. The state uses blogs and social networking tools for its own purposes.

For instance, Prime Minister Najib Razak runs a popular blog. And his Facebook page, with over 2.2 million fans, is the second most popular politician's page in the country behind the page of former Prime Minister Mahathir Mohamed. This is far more than the number of fans garnered by opposition leader Anwar Ibrahim. Despite being rather later in embracing social media, in 2010, the police force, Polis Diraja Malaysia or the Malaysian Royal Police, launched a new media centre and setup Facebook and Twitter accounts to provide updates on policing activities and occasionally respond to public accusations of abuse by police. By March 2014, there were 600,207 and 127,000 followers of the Polis Diraja Malaysia Facebook page and Twitter account (@pdrmsia), respectively.

In 2011, when the Bersih 2.o was deemed illegal, Polis Diraja Malaysia used Facebook to disseminate a video entitled 'Illegal Rally Bersih 2.0: A police perspective of gth July 2011' documenting various activities of Bersih protesters that were supposedly 'illegal'. It also released various Twitter statements encouraging citizens to report on protesters so as to be able to charge individuals who made 'false reports against the force' (Jaraparilla 2011). During the Bersih 3.o rally, @pdrmsia delivered 'Live from Polis Diraja Malaysia' tweets every 10-15 minutes with 'live reports' from various locations in Kuala Lumpur where the rally was held. Responding to accusations of street violence and police brutality during the Bersih 3.o rally, Polis Diraja Malaysia actively used @pdrmsia to deliver its side of the story by releasing selected videos showing the acts of 'unlawful rioters'. Additionally, the government also recruited cyber-troopers to post positive tweets about the government and the ruling coalition and simultaneously attack Bersih and the opposition with negative tweets. 
The Malaysian government did not directly deter citizens from using digital media for political activism such as Bersih but actively used the very same media to campaign against its opponents and to compete with the online dissent. This practice fits the 'networked authoritarianism' practice which occurs when 'an authoritarian regime embraces and adjusts to the evitable changes brought by digital communications' (MacKinnon 2011:33). Also, the government made use of on-the-ground crackdowns and physical threats, and continued to exploit legal apparatus to legitimize its power and control over on- and offline spaces.

Additionally, the government continued to use racial issues to cultivate the culture of fear among Malaysians. The Barisan Nasional government kept on disseminating messages that echoed what Mahathir Mohamed said in 1999, that 'a weak government will bring about chaos and racial rioting.... We did not get two-thirds majority [in 1969] and there were riots' (Borneo Post, 11 August 1999). No doubt, the racial riot of May 13, 1969 still haunts the Malaysian psyche and the event has been frequently used in general elections to discourage people from exercising their electoral choice. The Bersih movement, however, has always tried to break away from the racial division and, until the third rally, was relatively successful in recruiting a diverse group of Malaysian youths. The Bersih 4.0 rally, however, was reported as being dominated by the Malaysian Chinese, prompting observers to point out that the country's politics are indeed divided along ethnic lines. The rally organizers, on an the other hand, kept insisting that the Bersih movement is not grounded in ethnic or racial politics.

\section{Bersih is for and by (Urban) Malaysians}

Who constitute Bersih? Where did Bersih activists come from? Evidences from the field show that Bersih is about, by, and for Malaysians, in Malaysia and abroad, and on- as well as offline. As discussed in the previous section on Twitter, the majority of the supporters came from inside the country. Outside Malaysia, the Malaysian diaspora participated in the Global Bersih (2.0 and 3.0) movement by holding rallies in their cities/countries of residence. ${ }^{18}$ During the Bersih 2.0 rally, there were 4,300 participants who attended protests held in thirty-eight locations in sixteen countries. With the third rally, these numbers increased to eighty-five locations in thirty-five countries. Strikingly, the number of non-Malaysians who supported the movement through Twitter and Facebook is negligible.

18 See http://www.globalbersih.org for more information on Global Bersih. 
Although Bersih activists did attempt to get the rural population involved by organizing various non-digital activities such as traditional ceramah in mosques and community centres, the Bersih movement is generally an urban phenomenon. It is a predominantly urban, middle-class movement with activities concentrated in urban, well-wired areas such as Greater Kuala Lumpur (Klang Valley), Johor Baru and Penang. Internet access inequality is less pronounced in Malaysia than, for example, in Egypt and Tunisia during the Arab Spring. Over sixty-one percent of Malaysia's total population has access to the internet (ITU 2012), with rural areas having a much lower percentage. In 2012, over eighty-five percent of the Greater Kuala Lumpur population was connected to the internet. ${ }^{19}$ This urban tendency was clearly reflected in the result of the 2013 General Election: the votes for Pakatan Rakyat were concentrated in Malaysia's urban areas, while Barisan Nasional won most votes in non-urban and rural areas such as Sabah and Sarawak.

The prominent Bersih bloggers who can be considered as the 'leaders' of the movement are generally older political activists, journalists and intellectuals. A good number represent the People's Justice Party, the Democratic Action Party and the Pan-Malaysian Islamic Party (PAS), the three parties that made up the oppositional alliance Pakatan Rakyat. Beyond this small circle of 'leaders', the people who participated at Bersih rallies, online and on-the-ground, came from a cross section of Malaysia's multicultural society, with the youth as the dominant group. Bersih did not successfully transform Malaysia into a postracial society. However, as vividly depicted in many photographs documenting the rallies (that were proliferating online), Bersih visually painted a picture of multicultural Malaysia with relatively equal participation of Chinese, Indians and Malays, and a momentarily rejuvenated hope for Malaysia's non-racialized 'new' politics.

\section{Digital Media, Participation and Citizenship}

Having examined the history of the Bersih movement and the role of digital media in this movement, it is time to revisit the questions posed at the beginning of this chapter. Did digital media alter Malaysian political passivity, especially the youth's non-participation in politics? Has digital media transformed the Malaysians to be politically active? Has digital media influenced the notion of participation and citizenship among urban Malaysians? These questions

19 Based on the author's calculation. 
will be addressed in the following discussions, to generate a clear understanding of the relationship between digital media, participation and citizenship.

\section{Youth, Digital Culture and Citizenship: Learning and Becoming}

Considering that youth is a dominant social group participating in the movement, it is important to understand the relationship between this group and digital media, and how this relationship may or may not alter the notion of citizenship. Unlike what is generally thought about digital activists, young Malaysians who joined Bersih are not just geeks and hackers. In fact, the majority of Bersih activists are ordinary Malaysian urban youth whose everyday lives are inseparable from digital media. The reason why digital media, especially social networking tools, fits the urban youth has less to do with the inherent emancipatory power of the technology, but more with the embedding of this new technology in the everyday social and cultural life of the members of this generation. Digital media is ubiquitous for the Malaysian youth. A 2008 study by Rahim and Pawanteh (2011:9) reports that ninety-two percent of the young adult Malaysians had access to personal computers and the internet. The socalled 'new technology' is not exogenous to young people's experiences but part of their daily social and cultural constructs. Accordingly, notions such as socializing, communicating, and learning for these young people, too, have changed.

Jenkins et al., (2006:xi) suggests that the digital culture has altered ways in which young people learn. By experimenting with digital media, young people are actively involved in a participatory culture, which is 'a culture with relatively low barriers of artistic expression and civic engagement, strong support for creating and sharing creations, and some type of informal mentorship whereby experienced participants pass along knowledge to novices'. Such a learning style has implications on how they approach, interpret, learn and participate in politics. In other words, digital culture alters the way the younger generation practices citizenship. From the Bersih case, we learn that digital media has provided a space for young Malaysians to immerse in the culture that helps establish 'a learning space to express their opinions, to exercise their [social] rights, and to collaborate with each other' (Lim 2013:654). Digital media, however, does not directly empower Malaysians with an agency to exercise their citizenship through their participation in politics and engagement with the state. It is only through their continued involvement in the Bersih movement, online and offline, that they recognize and learn about their rights as citizens and by doing so, they claim their agency and create a trajectory for becoming a 'whole' citizen, a new conception of citizenship that is different than what was sanctioned by the state. 


\section{Participatory Culture versus Electoral Politics}

It is commonly assumed that young people are not interested in 'old-style' politics and that online participation is not directly related to participation in traditional electoral politics like political campaigns or voting. In fact, scholars generally agree that young people prefer to focus on lifestyle politics, political consumerism, volunteering and social activism, and that they are generally disconnected from traditional electoral politics (Bennett et al., 2009; Levine 2007; Zukin et al., 2006). Palfrey and Gasser (2008) suggest that the so-called 'digital natives' favour more personally expressive politics in digitally mediated environments. They mistrust the media and the government, are less likely to follow politics in the news, and have a weak sense of duty to participate in government (Bennett et al., 2009:107).

The Bersih story, however, suggests that these presumptions do not always completely hold. While it is true that for the younger Malaysians and 'digital natives' much of the party politics and government elements of politics are distant and inauthentic, they still see voting - when it is 'bersih' (clean), free, and fair - as the core democratic act. Many young Malaysians do not consider politics as the problem, but they despise the practice of politics, which they describe as 'dirty, corrupt and hegemonic'.

Further, it is misleading to assume that youth in general are apolitical and disengaged. After all, youth are not monolithic. As exemplified in the Bersih case, there are always young people of the activist type who are ready to engage and participate when presented with an opportunity. It is through interactions with the latter that other young people might become involved in participatory politics.

\section{Insurgent Citizenship in Cyber-Urban Space}

Admittedly, digital media in Malaysia operate under the logic of capitalism and control of the government. Its function as a civic space is always dependent on socio-political arrangements that are enacted upon it. Nonetheless, in cyberspace, Bersih and the reformist activists have the upper hand in defining the meaning of this space. It is a space for multiple alternative spheres, subaltern counter-publics, to exist (Lim 2014). Meanwhile, in the non-digital cityscape, the Bersih movement has revived the rights of citizens to have aspirations about what can be changed collectively in the city. It is in cyber-urban space (Lim 2015) - the integrated space of digital and physical urban spaces - that the Bersih participants redefined their relationship as citizens with the state.

However, Bersih did not structurally change the practices of politics in Malaysia. Neither did it transform the country into a post-racial society. However, cyber-urban activism has recast the landscape of socio-political 
engagement in the country, by (re)opening civic spaces for citizens to exercise their freedom of speech and expression and by encouraging citizens to participate in the discussion on their country's future. It is not known if the use of digital media platforms for citizens and oppositional political actors will lead the country to a structural political transformation. What is clear is that Bersih activists have appropriated the Malaysian cyber-urban space to mobilize citizens to collectively voice their opinions, claim their rights as citizens in public space in a series of public protests. In turn, cyber-urban activism has meaningfully changed the ways urban citizens perceive their rights to public spheres and spaces, and redefine their relationship with the state. Claims and rights are a defining characteristic of citizenship. The claim of public space is essentially about 'insurgent citizenship' (Holston 1998) and the promotion of 'insurgent practice' that aims to support new citizenship claims (Douglass and Friedmann 1998). The fight of urban, middle-class Malaysians for their right of access to the public sphere and freedom of expression is based on insurgency, a struggle over the meaning and orientation of citizenship. As opposed to a statist citizenship that assumes that the state is 'the only legitimate source of citizenship rights, meanings and practices' (Holston 1998:38), insurgent citizenship entails engages citizenry who actively negotiate 'what it means to be a member in the modern state' (Holston 1998:47).

\section{Conclusion}

The Bersih story provides a compelling example of how the use of digital media acquires its shape in specific and multifaceted historical conditions. What we call 'impacts' of digital media is not the result of technological processes but rather of historical processes. Accordingly, the role of digital media should be positioned and contextualized within a decade-long complex history of political reform. In this historical context, digital media has been used to profoundly alter strategies and discourses related to political reformism and citizenship, and might contribute to future successes, and ultimate effectiveness of of the movement for political reform.

The Bersih case also illustrates that as a socio-material artefact, every digital platform (blogging, Facebook and Twitter) has its own socio-political properties that postulate distinctive affordances and limitations for its users. The Bersih movement, illustrates that, unlike Facebook which is valuable for expanding and growing networks, blogging proves a suitable medium for establishing the core of the activist network, especially by facilitating the brokerage. 
As for Twitter, its portability and swiftness made it suitable for real-time communication and broadcasting during the actual protest event.

Resting at the fact that Bersih is largely an urban middle class movement, we also learn that digital media as technology do not operate in a contextual vacuum. While these media may widen and broaden the space for political participation for Malaysians, with a high concentration of internet access in urban areas, Bersih's reliance on digital media contributed to the under-representation of rural individuals and groups in the movement.

Digital media do not stand apart as an autonomous force that impacts politics. Digital media is not a magic wand that transforms the so-called political passivity of Malaysians into enthusiastic involvement in participatory politics. By exploring how digital media including blogging, Facebook and Twitter were utilized and appropriated by supporters of the Bersih movement, this chapter has argued that digital media is very much a part of the socio-political landscape it attempts to transform. Therefore, the impact of digital media on politics and its role in societal change should be understood as the 'result of the organic interaction between the technology and social, political, and cultural structures and relationship' (Lim 2013:637). Digital media are shaped by the political and cultural arrangement in which they operate and are used. In the Malaysian context, and in relation to Bersih in particular, the dominant users are urban middle-class Malays, particularly the youth. With the young generation of 'digital natives', notions of political participation in exercising citizenship are changing. Technology did not transform Malaysians into politically active citizens, but by appropriating digital media in their pursuit of reforming politics, Bersih activists offered new possibilities for participation and engagement in politics, especially for young people. They expanded the space for people's agency in shaping the future of politics in the nation.

This chapter shows that in the Bersih movement, Malaysians have learned to recognize their rights and claim them through participating in the practices of activism in the cyber-urban space. Such practices embody instances of 'insurgent citizenship' (Holston 1998), which are political practices challenging established notions of citizenship as defined by the state (and the ruling coalition) and claiming new conceptions of citizenship. Through subversive practices of insurgent citizenship, urban middle-class Malaysians have crafted a pathway towards a new type of relationship between the state and its citizen. Also, these practices challenged the existing power balance between the state and civil society, especially in public spheres. The outcome of this continuous contestation between insurgent citizens and the state will be crucial in defining the future of Malaysian democracy (Lim 2008). 
While digital media has temporarily steered the country towards the seemingly more desirable trajectory of participatory politics, the future role of digital media in the Malaysians' pursuit for citizen participation and the pathway to citizenship and democratic culture, is neither certain nor predetermined. What is clear is that urban middle-class Malaysians, especially young people, will continue to be part of the contestation for the future of reform, democracy and electoral politics in the country, and that digital media will continue to play a role in the struggle.

\section{References}

Abbott, J.P. (2004). The Internet, reformasi and democratization in Malaysia. In E.T. Gomez (Ed.), State of Malaysia (pp. 79-104) London: Routledge.

BDHRL (Bureau of Democracy, Human Rights and Labor) (2011). 2010 Human Rights Report: Malaysia. Retrieved from: http://www.state.gov/j/drl/rls/hrrpt/2010/eap/ 154391.htm.

Bennett, W.L. (1998). The uncivic culture: Communication, identity and the rise of lifestyle politics. PS: Political Science and Politics, 31(4), 740-761. http://dx.doi .org/10.1017/S1049096500053270.

Bennett, W.L., Wells, C., \& Rank, A. (2009). Young citizens and civic learning: Two paradigms of citizenship in the digital age. Citizenship Studies, 13(2), 105-120. http:// dx.doi.org/10.1080/13621020902731116.

Brisbin, D. (1988). Electronic revolution in the Philippines. The Journal of Popular Culture, 22(3), 49-64.

Bunnell, T. (2004). Malaysia, Modernity and the Multimedia Super Corridor: A Critical Geography of Intelligent Landscapes. London: RoutledgeCurzon.

Crispin, S.W. (2013). In Asia, Three Nations Clip Once-Budding Online Freedom. Retrieved from: https://www.cpj.org/2013/o2/attacks-on-the-press-internet -opening-is-shrinking.php.

Douglass, M. and Friedmann, J. (1998) Cities for citizens: planning and the rise of civil society in a global age. New York NY: Wiley.

Downing, J. (2010). The Sage Encyclopedia of Social Movement Media. Boston: South End Press.

Gladwell, M. (2010, October 4). Small Change: Why the revolution will not be tweeted. The New Yorker. Retrieved from: http://www.newyorker.com/magazine/2010/10/04/ small-change-malcolm-gladwell.

Goldenberg, J., Libai, B., \& Muller, E. (2001). Talk of the network: A complex systems look at the underlying process of word-of-mouth. Marketing Letters, 12(3), 211-223. 
Harb, Z. (2011). Arab revolutions and the social media effect. Media/Culture Journal, 14(2). Retrieved from: http://journal.media-culture.org.au/index.php/mcjournal/ article/view/364.

Holston, J. (1998). Insurgent Citizenship: Disjunctions of Democracy and Modernity in Brazil. Princeton, NJ: Princeton University Press.

Howard, P., \& Hussain, M.M. (2012). Democracy's Fourth Wave?: Digital Media and the Arab Spring. Oxford: Oxford University Press.

Internet World Stats (2012). Asia Internet Stats. Retrieved from: http://www internetworldstats.com/asia.htm.

ITU (2012). Measuring the Information Society. Retrieved from: http://www.itu.int/ en/ITU-D/Statistics/Documents/publications/mis2013/MIS2013_without_Annex_4 .pdf.

Jaraparilla (2011). How Wikileaks is helping change Malaysia. Retrieved from: http:// wlcentral.org/node/2113.

Jenkins, H., Purushotma, R., Weigel, M., Clinton, K., \& Robison, A.J. (2006). Confronting the Challenges of Participatory Culture: Media Education for the 21st Century, a report to MacArthur Foundation. Retrieved from: http://mitpress.mit.edu/sites/ default/files/titles/free_download/9780262513623_Confronting_the_Challenges. pdf.

Joseph, S. (2011). Social Media, Human Rights and Political Change. Melbourne: Monash University.

Lee, J.C.H. (2007). Barisan Nasional - Political dominance and the General Elections of 2004 in Malaysia. Sudostasien aktuell, 2, 38-75.

Levine, P. (2007). The Future of Democracy: Developing the Next Generation of American Citizens. Medford, MA: Tufts University Press.

Lim, M. (2003). The Internet, social network, and reform in Indonesia. In N. Couldry \& D. Miller (eds.), Contesting Media Power: Towards a Global Comparative Perspective (pp. 273-288). Lanham, MD: Rowan and Littlefield.

Lim, M. (2008). Transient civic space in Jakarta demopolis. In M. Douglass, KC Ho, \& GL Ooi (Eds.), Globalization, the City and Civil Society in Pacific Asia (pp. 212-230). London: Routledge.

Lim, M. (2013). Many Clicks but Little Sticks: Social Media Activism in Indonesia. Journal of Contemporary Asia, 43(4), 637-657. http://dx.doi.org/10.108o/o0472336 .2013.769386.

Lim, M. (2014). Seeing Spatially: People, Networks and Movements in Digital and Urban Spaces. International Development and Planning Review, 36(1), 51-72. http:// dx.doi.org/10.3828/idpr.2014.4.

Lim, M. (2015). A Cyber-Urban Space Odyssey: The Spatiality of Contemporary Social Movements. New Geographies, 07, 117-123. 
Lim, M., \& Kann, M. (2008). Networked politics: Deliberation, mobilization and networked practices of agitation. In K. Varnelis (Ed.), Networked publics (pp. 77107). Cambridge, MA: MIT Press.

MacKinnon, R. (2011). China's networked authoritarianism. Journal of Democracy, $22(2), 32-46$.

Margolis, M., \& Resnick, D. (2000). Politics as Usual: The 'Cyberspace Revolution'. Thousand Oaks, CA: Sage Publications.

McAdam, D., Tarrow, S., \& Tilly, C. (2001). Dynamics of Contention. Cambridge: Cambridge University Press.

Morozov, E. (2013). To Save Everything, Click Here: The Folly of Technological Solutionism. New York, NY: Public Affairs Book.

Neuman, WR, Bimber, B., \& Hindman, M. (2011). The Internet and Four Dimensions of Citizenship. In RY Shapiro and LR Jacobs (Eds.), The Oxford Handbook of American Public Opinion and the Media (pp. 22-42). Oxford: Oxford University Press.

O'Shannassy, M. (2009). Beyond the Barisan National? A Gramscian perspective of the 2008 Malaysian General Election. Contemporary Southeast Asia: A Journal of International and Strategic Affair, 31(1), 88-109.

Palfrey, J., \& Gasser, U. (2008). Born Digital: Understanding the First Generation of Digital Natives. New York, NY: Basic Books.

Pandi, A.R. (2011). Blogging and political mobilization among minority Indians in Malaysia (Unpublished doctoral dissertation). University of Hawaii, Honolulu HI.

Pandi, A.R. (2014). Insurgent space in Malaysia: Hindraf movement, new media and minority Indians. International Development Planning Review, 36(1), 73-9o. http:// dx.doi.org/10.3828/idpr.2014.5.

Rahim, S.A., \& Pawanteh, L. (2011). Democratization of information in Malaysia: A response to globalization. Asian Social Science, 7(2), 3-11.

Rane, H., \& Salem, S. (2012). Social media, social movements and the diffusion of ideas in the Arab Uprisings. Journal of International Communication, 23(2), 74-88.

Rodan, G. (2005). Transparency and Authoritarian Rule in Southeast Asia: Singapore and Malaysia. London: RoutledgeCurzon.

Scott J. (1990). Dominations and the arts of resistance: Hidden transcripts. New Haven, CT: Yale University Press.

SDMA (2012). Social, Digital and Mobile in Malaysia. Retrieved from: http://wearesocial .net/tag/sdma/page/3/.

Sheriff, N. (2011, August 17). Malaysia's 'silent' awakening. The Nation. Retrieved from: http://www.thenation.com/article/malaysias-silent-awakening/.

Sreberny, A., \& Mohammadi, A. (1994). Small media, big revolution: Communication, culture, and the Iranian revolution. Minneapolis, MN: University of Minnesota Press.

Starr, A., Fernandez, L., \& Scholl, C. (2011). Shutting Down the Streets: Political Violence and the Social Control in the Global Era. New York, NY: New York University Press. 
Sysomos (2011). Egyptian crisis: The revolution will not be tweeted. Retrieved from: http://archive.is/feTI.

Tilly, C. (2003). The Politics of Collective Violence. Cambridge: Cambridge University Press.

TNS (2010). Global 'Digital Life' Research Project Reveals Major Changes in Online Behavior. Retrieved from: http://www.prnewswire.com/news-releases/ global-digital-life-research-project-reveals-major-changes-in-online-behaviour $-104660154 . h t m l$.

Weiss, M. (2007). What a little democracy can do: Comparing trajectories of reform in Malaysia and Indonesia. Democratization, 14(1), 26-43. http://dx.doi .org/10.1080/13510340601024280.

Weiss, M. (2012). Politics in Cyberspace: New Media in Malaysia. Retrieved from: http:// www.fes-asia.org/media/publication/2012_PoliticsInCyberspace_fesmediaAsia _Weiss.pdf.

Weiss, M. (2014). Parsing the power of 'new media' in Malaysia, Journal of Contemporary Asia, 43(4), 591-612. http://dx.doi.org/10.1080/o0472336.2012.759332.

World Bank (2012). Global Development Finance: External Debt of Developing Countries. Retrieved from: http://data.worldbank.org/sites/default/files/gdf_2012.pdf.

York, J. (2011, January 14). Not Twitter, not Wikileaks: A human revolution. Retrieved from: http://jilliancyork.com/2011/o1/14/not-twitter-not-wikileaks-a-human-revolution/.

Zukin, C., Keeter, S., Andolina, M., Jenkins, K., \& Delli Carpini, M.X. (2006) A New Engagement? Political Participation, Civic Life, and the Changing American Citizen. Oxford: Oxford University Press. 


\title{
Citizenship, Rights and Adversarial Legalism in Thailand
}

\author{
Wolfram Schaffar
}

In February 2013, several hundred demonstrators took to the streets of Bangkok and marched along the Rajadamdern Road in front of the government building to protest the EU-Thai Free Trade Agreement (Donttradeourlivesaway 2013a, 2013b). ${ }^{1}$ Bangkok has seen a lot of mass demonstrations during the past couple of years - the anti-Thaksin demonstrations in 2006, the protests of the Yellow Shirts in 2008 that culminated in the siege of the airport, the mass demonstration of the Red Shirts in 2010, which was bloodily cracked down by the military and left ninety people dead, and recently, the mobilization of the Yellow Shirts from November 2013 to March 2014 which paved the way to another coup d'état in May 2014. The demonstrations against the EU-Thai Free Trade Agreement, however, were not directly connected to the Red versus Yellow divide and were quite unique as far as their performance, and the composition and character of the protesters was concerned. The protesters were wearing white shirts, white gloves and orange headbands and appeared almost uniformed. They did not just assemble as a crowd with protest banners and megaphones, but in a very organized, nearly ritual form. They marched in a formation of several parallel rows, with their hands folded in front of their chest as if they were greeting using the traditional, respectful Wai. Following a strict choreography, all protesters kneeled down and bowed to the ground from time to time (Donttradeourlivesaway 2013a, 2013b).

The group mainly consisted of small-scale farmers and people living with HIV and AIDS (PLHA) (Pongphon 2013a, 2013b). This is a rare coalition of two interest groups who do not seem to have much in common at first sight. However, in the case of Thailand, these groups have not joined forces in a singular or spontaneous move, but represent a stable coalition that has been working together for almost a decade. In addition to the long history of their cooperation,

1 The empirical foundation of this chapter was laid in a research project on 'Constitutionalism in Thailand from the Perspective of Social Movements' supported by funds of the Oesterreichische Nationalbank (Anniversary Fund, project number 14710). The theoretical framework of citizenship I owe to Henk Schulte Nordholt, Gerry van Klinken and Ward Berenschot and our numerous discussions during my stay as research fellow at KITLV. 
the different groups show a high of degree of integration as far as their performance in public is concerned. On their banners and t-shirts, groups of PLHA do not express a specific identity as HIV-positive, at least not to the extent of PLHA groups in other parts of the world. ${ }^{2}$

The protest was also remarkable because of the slogans and demands that were voiced on the streets. In their press release, the protesters announced that they 'call for transparency and people's participation in the FTA negotiation with the EU in accordance with the Constitution's Section 19o' (Donttradeourlivesaway 2013a). What is remarkable about this demand is that it lacked any reference to specific rights. Although the immediate concern of the protesters was to secure access to drugs by protesting against a tightening of patent protection, there was no slogan referring to a specific human right to healthcare and no reference to Article 51 of the Thai Constitution that guarantees free medical treatment. Small-scale farmers, likewise, did not refer to community or other cultural rights to fence off integration in and exposition to the world market (Bencharat 2013).

According to the most common definitions, citizenship is about claiming rights through formal institutions (Marshal 1950, Isin and Turner 2002). But obviously, the demonstrators in Thailand are not behaving as an interest group who perform a specific identity and voice their concern in a language of rights. What does this example of political activism tell us about citizenship in a nonWestern, postcolonial setting like Thailand?

\section{Citizenship, Rights and Adversarial Legalism}

Citizenship is defined as the relation between a person and state authorities. Most authors distinguish between several schools of thought - republican, liberal and communitarian (Isin and Turner 2002; see also the Introduction in this volume). The liberal tradition - often departing from Hannah Arendt's famous dictum of 'the right to have rights' - sees citizenship as a legal status concerning the question in how far a person can claim universal rights. Citizenship struggles are interpreted as struggles for rights, extending citizens' rights and broadening the group of citizens who can enjoy these rights. A communitarian view also departs from a concept of rights, but draws into question the

2 When PLHA in South Africa stage a protest, for example, the performance of a specific identity as HIV-positive is a crucial element therein. To turn the diagnosis into a 'batch of pride' (Robins 2004, 2006) is part of a strategy to challenge the stigmatization as of being HIV-positive. 
universality of rights. Instead, it stresses the membership of an individual in a certain group and the relevance of this belonging for political participation. Being discussed in this perspective are differentiated forms of citizenship. In order to respond to the specific needs of ethnic, religious or other minorities, specific cultural or religious rights, rights for access to resources or services, as well as to political representation are seen as important issues. The republican tradition is less directly centred on rights but rather stresses the participation of citizens in the political processes by which rights are created and expanded.

To a different degree, and depending on the author, all these interpretations are closely connected to the concept of rights - one could also say that they are all biased towards rights-based reading. Most prominently, this bias can be found in Tilly's (1995:8) definition of citizenship. In his sociological perspective, citizenship can be observed in the everyday interactions between people and state authorities. However, as Berenschot, Schulte Nordholt and Bakker (2017) characterize it in the Introduction, 'only when these interactions involve claiming and granting of rights that are enforceable and realized in a manner devoid of personal considerations...does this transaction "count" as an instantiation of citizenship.'

The emphasis on a legal interpretation and the centrality of the notion of rights, however, mirrors a general tendency in political thinking and global political developments. For Smith (2002), this rights-centred interpretation is the result of a historic shift. Smith notices that a more rights-focused interpretation of citizenship - the liberal and communitarian interpretation - has come to the foreground at the expense of republican readings that stress political participation. He sees this shift as the result of globalization processes that have brought about the dissolution of the nation-state, which used to be the point of reference of republican citizenship engagement - according to Smith an inevitable result of globalization and yet - from a normative-ontological perspective, he criticizes it for its de-politicizing effect. ${ }^{3}$

Apart from citizenship studies, the shift towards a focus on rights and legal processes has also been noted on other levels of global political development: from a political science and sociology of law perspective, Kelemen and Sibbitt (2004) and Kelemen (2011) analyse the shift toward rights-centred public policy as an effect of the spread of the Us-American legal culture - a specific culture which has been described as 'adversarial legalism' by Kagan (2003). In contrast to other industrialized countries, where policymaking and implementation

3 As I will show later in this chapter, a turn towards rights is not the only possible development resulting out of globalization processes (cf. Demirović 2011 and Band, Görg and Wissen 2011 for a discussion of processes of internationalization or transnationalization of the state from the perspective of critical state theory). 
is achieved through the cooperation between politicians, bureaucrats and judges, the us-American system emphasizes lawyer-dominated litigation and punitive sanctions in the policy and administrative process. Kelemen argues that this system is spreading to more and more countries and regions, enabling big law firms to expand their business activities in situations of political fragmentation. I want to claim that the generalization of adversarial legalism as the unmarked global way of politics also influences the political science discourse on citizenship in so far as it suggests that the typical citizen is a rightsconscious subject who claims his/her rights through court action.

As much as a specific culture of rights and legal procedures is expanding in the industrialized world, this tendency can also be observed in and has effects on the Global South. International development institutions increasingly tend to address social and political issues as legal problems. The problem of gender discrimination, for example, the discrimination of disabled people, of ethnic, religious or other minorities is dealt with via a definition of enforceable universal human rights - in the sense of liberal citizenship - or via specific anti-discrimination laws - in the sense of communitarian citizenship. One example is the Convention on the Elimination of All Forms of Discrimination against Women (UN 1979) that has been called the Bill of Rights for Women by the United Nations. More recent examples are the Convention on the Rights of Persons with Disabilities (2006) or the Declaration of the Rights of Indigenous People (2007). The former shifted the perception of disabled people from objects of charity and medical treatment or social protection to citizens - full and equal members of society in the sense of rights-bearing subjects. Moreover, even classical socio-economic development issues such as the problem of poverty are increasingly interpreted as legal problems. Since 2008, the United Nations Development Programme (UNDP) has pursued a rights-based programme to cope with problems of inequality, entitled Legal Empowerment of the Poor and the Eradication of Poverty (UN 2009). The idea behind this programme is that poverty not only excludes people from enjoying their fundamental rights as a secondary effect, but that creating legal consciousness and encouraging people to claim their rights can serve as a strategy to overcome poverty.

The example of this legal empowerment programme illustrates the fundamental rationale behind a rights-based development approach, which relies on the intrinsic as well as instrumental value of rights. On the one hand side, the Charter of Human Rights as such is acclaimed for its intrinsic value as the only universally accepted code of values. ${ }^{4}$ On the other hand side, making use of these rights in courts is seen as a powerful tool for bringing about

4 Following Nowak, Januszewski and Hofstätter (2012) the author strongly supports the view of Human Rights as universal value system. The cases discussed in this chapter do not show 
development. A central role for the appreciation of this idea is played by the constitutional court of South Africa, which has set new global standards of the interpretation of human rights. Whereas for a long time, only so-called first and second generation rights, that is liberty rights and political rights, where seen as being enforceable, the South African constitutional court passed a number of judgements which opened a new chapter in the interpretation of social rights, such as the right to access to healthcare, housing, water, et cetera (Jones and Stokke 2005).

In order to make rights-based development work, however, it is necessary that people not only know about their rights but also internalize them and develop a consciousness as rights-bearing subjects. Only on the basis of this self-identification, the legal instruments of CEDAW or the concept of Legal Empowerment of the Poor and the Eradication of Poverty can lead to success. Legal consciousness - that is the cognitive and social processes by which individuals perceive themselves as rights-bearing subjects and give meaning to their social world according to legal concepts - is gaining more and more attention in studies of sociology or anthropology of law. Using the example of CEDAW, Merry (2001, 2006a, 2006b) has analysed the processes through which international legal norms are implemented. She characterizes the complex process through which rights are translated in different contexts as vernacularization - the emergence of a specific local legal consciousness.

All three aspects of rights-based development are addressed by more and more development cooperation programmes (see Ebenau 2012 for a critique). First and foremost, in constitutional reforms, as well as through the implementation of international rights standards, human rights are set up as legal norms and translated into national law. To unfold the instrumental power of rights, the institutional level is addressed. Capacity-building programmes for judges and bureaucrats working in the institutions of the judicial branches, are ranking high in the portfolio of international development agencies. And finally, special trainings for legal consciousness are offered to grassroots organizations.

\section{Critique}

What Merry (2001) describes as a process of vernacularization is the basis for strong criticism from Robins et al., (2008:1071). From a postcolonial perspective,

that Human Rights are not valid in the Global South. They only show that a rights discourse does not play the same central role for the notion of citizenship. 
Robins et al., criticize the idea of rights-based citizenship as a Western concept that does not make much sense in the Global South - except for an urban middle-class minority. Drawing on Chatterjee's (2004) concept of a political society, they claim that the majority of poor and powerless people have to cope with a situation of informality and illegality that forces them to muddle through by building alliances and entering clientelist relationships. Keeping rights-based citizenship as an ideal for development and democratization, they argue, amounts to a neo-colonial project of imposing Western norms on the Global South, with the goal of disqualifying the patterns of citizenship in postcolonial states as a 'cluster of absences' (Isin 2002:130). To overcome such a Eurocentric perspective, Chatterjee and Robins et al., demand that we reinterpret patronage and personalized informal networks as forms of citizenship of their own right - as genuine forms of citizenship in the South.

How do the behaviour of the Thai movements and the recent protests of PLHA fit into this picture? In what follows, I will argue that the strategy of the Thai Network of People Living With HIV and AIDS (TNP+), its coalition partners, and the identity of the members show distinctive features of a specific kind of citizenship. This pattern of citizenship is not based on a rights discourse and does not involve court action or other forms of adversarial, rightsclaiming legal activities. In so far, it differs from what mainstream citizenship literature would make us expect from a well-established democracy. However, at the same time, Thai PLHA insist on participating in the formal political process. This shows that their behaviour is also different from what can be observed as patterns of citizenship in post-Suharto Indonesia (Van Klinken 2009; Schulte Nordholt and Van Klinken 2007; Schulte Nordholt 2011). What Van Klinken and Schulte Nordholt have documented and analysed here is the emergence of citizenship patterns based on patronage, personalized and informal networks which seem to come close to what Robins, Cornwall and von Lieres (2008), drawing on Chatterjee (2004), would consider to be a type of postcolonial citizenship. Yet the demands of Thai protesters to follow the formal rules of the legislative procedures and to have an open parliamentary debate on the EU-Thai Free Trade Agreement does not fit into this category of postcolonial informal citizenship, too.

\section{Legal Consciousness and Adversarial Legality in Thailand}

Thailand has been exposed to globalization processes for a long time. Because of its entrenched pro-democracy movements, and especially in the 199os, the 
country has been seen as a flagship of democratization in Southeast Asia. As such, Thailand was the focus of many institutions running democratization support programmes, using ideas of a rights-based development paradigm.

A landmark of this development was the promulgation of the People's Constitution in 1997, which laid the institutional foundation for rights-claiming civic action. The constitution contained a detailed and explicit Charta of fundamental rights and introduced a number institutions that should guard the compliance with these rights: a human rights commission, an anti-corruption commission, an administrative court and above all, a constitutional court. This constitutional model very much mirrored the influence of international counselling, as it was closely connected to the worldwide trend of constitutional design of the 1990s, which was based on principles of good governance and emphasized the importance of rights-bearing active citizens.

This reform process was actually initiated by a coalition of civil society organizations and the draft text was discussed in numerous public hearings prior to the promulgation. According to Munger (2006/2007), this public participation during the process of drafting a new constitution can be interpreted as sign of a mature legal consciousness in Thailand. However, based on the Asia Value Survey, he concludes that while support for democracy is ubiquitous, there is a split within the population that follows urban versus rural, modern versus traditional and more versus less educated lines. Rural, traditional, less educated people tend to accept traditional values. They reject minority rights, have more faith in social and political institutions, but show no trust in rule of law.

Engel and Engel's (2010) sociological study on the northern province of Chiang Mai illustrates this rural mind-set. Their study is based on tort cases and shows an interesting tendency: despite the progressive integration of Thailand - including Northern Thailand - into globalized economic and social exchanges, the number of tort cases where victims of traffic accidents have sued another party for compensation, have declined over the period of twenty years. As their qualitative interviews reveal, victims of traffic accidents are increasingly interpreting their accidents in terms of religious concepts. For example, as the result of bad karma of the victim, and this bad karma might have been brought about by the misbehaviour of family members. Some victims see a ghost living at the site of the accident as the reason for their misfortune. Due to Engel and Engel's interpretation, the processes of globalization, increased mobility, et cetera, have dissolved traditional forms of compensation, which relied on personal relationships, moral principles and local authorities within the community. However, new forms of rights-based, rational litigation in court have not replaced the old personalized forms. Instead of a legal analysis of the accident - an interpretation of how the accident came about as a result 
of someone else's unlawful behaviour - victims seem to resort to religious interpretations in order to give the accident a 'meaning'.

This reluctance to use courts as arenas for litigation seems to be mirrored in the political culture. As an example, Munger (2007:471) cites the Assembly of the Poor, a network of small-scale farmers and fishermen/women who staged large demonstrations throughout the 199os in opposition to destructive government-sponsored development projects. Munger notes that in their strategy, the Assembly of the Poor relied on spectacular demonstrations, media campaigns and petitions directly addressed at governmental officials. They appealed to traditional concepts of popular welfare and moral accountability instead of formal law and litigation. He draws the conclusion that in rural Thailand, where adversarial legalism is less familiar or common, Thai social movements have seldom relied on litigation to advance their goal'.

This might create the impression that rights-based interactions between citizens and the state are mainly to be found among the urban middle class in Bangkok. Chatterjee (2004) and Robins et al., (2008) consider this contrast between affluent urbanites and poor villagers typical for postcolonial states. The majority of inhabitants in rural areas outside the city perceive their fate more in terms of in religious categories. In order to get access to state resources and be heard in the political process, they have to rely on personalized, clientelist structures and they appeal to moral obligations rather than rights. The recent split between the two antagonistic political camps, the Red Shirts and the Yellow Shirts, is often interpreted along the same lines: on the one hand, the Red Shirts with their base in the poor population in the rural North and Northeast relying on Thaksin as their patron, and on the other hand, the Yellow Shirts coming from the urban middle classes in Bangkok who insist on 'clean' politics and relying on legal procedures.

However, there are a number of problems with this interpretation. Firstly, if we look into the dynamics of rural social movements in Thailand, the picture becomes less clear. For example, the Assembly of the Poor, who Munger (2007) characterizes as a rural movement relying on non-rights-based forms of activism, have not joined the camp of the Red Shirts as one would have expected. Rather, the entire movement collapsed in 2006/2007 over the question whether to support Thaksin or not. In the end, some central leaders have sided with the anti-Thaksin camp, whereas others joined the pro-Thaksin Red Shirts (Pye and Schaffar 2008).

Secondly, the Yellow and Red Shirt camps have considerably changed since they emerged in 2006. Today, it would be difficult to characterize the Yellow Shirt movement as an urban, middle-class movement representing Western ideas of rights-based citizenship. Rights and legal institutions do play a role in 
so far as the royal-conservative Yellow Shirts strategically use their privileged access to the constitutional court and other institutions to challenge the popular power of the pro-Thaksin camp. However, for their ideological foundation in their claim to power, they are more and more referring to a moral and personalized discourse that uses the monarchy as the source of legitimacy. In their rallies in 2008 and 2013, the Yellow Shirts called for a government of royally appointed, morally trustworthy people, rather than elected representatives. The Red Shirts, on the contrary, have more and more moved away from their orientation towards the strongman Thaksin. In their 2010 protests, they challenged the personalized and opaque power games of the royalist-conservative elites and called for fair and free elections and impartial courts. As Walker (2012) points out, rather than being a movement of the rural poor, one of their social bases are lower middle-class farmers who demand access to state resources including state power - on the basis of equality. This characterization of the two camps is also supported by a survey which covers the most recent demonstrations (The Asia Foundation 2013).

Thirdly, in Thailand we can observe the political dangers of a discourse which focuses on binary dichotomies like urban versus rural, Global North versus Global South, liberal versus clientelist. Robins et al., (2008) and Chatterjee's (2004) political agenda is to reject a Western discourse on citizenship that takes rational, impersonal and rights-based interpretations as norm. Their focus on divergent patterns of citizenship in the Global South intends to make visible other forms that are most often discredited as 'cluster of absences' (Isin 2002:130) in a normative discourse.

However, a focus on these different, divergent patterns - with the good intention of positive discrimination - bears the danger of 'othering' (in the sense of Spivak 1985). In the case of Thailand, this effect can be seen in the persistent debate on vote buying and clientelism in the rural areas of the North and the Northeast (Callahan 2005), which by now has developed a life of its own and is largely detached from any empirical evidence. While studies show that actual instances of vote-buying have steadily declined over the years, some academics and leaders of the Yellow Shirts insist that it is still the predominant pattern of behaviour, deeply rooted in the political culture of the North. They push this argument to the point to include Thaksin's social security and infrastructure programmes, which benefit the rural areas, as a form of 'abstract vote-buying' or legal corruption' (Thirayuth Boonmee, cited in Callahan 2005; Thongchai 2008a).

Moreover, a postcolonial discourse on different social and political patterns in rural Thailand serves as the ideological foundation for an anti-democratic alliance between leftists and royalists (Thongchai 2008b). On the basis of a 'localist' analysis, purporting that people in rural areas behave according to 
different, non-capitalist social patterns, formerly left-wing pro-democracy activists have argued that the rural masses are prone to be misguided and deceived and have to be saved from the turbo-capitalist Thaksin. Against this backdrop, left-wing activists joined hands with royal conservative elites who also oppose Thaksin and who advocate a Thai-style, royally guided democracy without popular elections.

In what follows, I will argue that the dichotomy of Western-style rights-based movements on the one hand and postcolonial personalized/clientelist style movements on the other does not adequately describe the types of citizenship one finds in Thailand. Concerning rural movements such as The Assembly of the Poor, Somchai (2006) has given a detailed analysis that goes beyond this dichotomy. He has shown that the specific organizational patterns and political demands, which Munger (2007) sees as sings of a rural mind-set, can be analysed as a conscious strategic choice. With their strategy to stage spectacular demonstrations and issue petitions directly to the prime minister, Assembly of the Poor reacted to repeated successful attempts of Thai authorities to co-opt single groups and curb rural protest in a divide-and-conquer manner. I have discussed elsewhere that the engagement of Assembly of the Poor can also be described as a kind of innovative radical democratic movement - comparable to movements of indigenous people like the Zapatista movement in Mexico or the Aymara movements in Bolivia (Schaffar 2011). In the following, I will use the example of TNP+, the Thai Network of People Living With HIV and AIDS, to show how people living with HIV and AIDS (PLHA) developed a form of citizenship that is neither rights-based, or 'Western', in the terms of Robins et al., (2008) and Chatterjee (2004), nor clientelist.

\section{HIV Activism in Thailand}

In Thailand, the first cases of HIV and AIDS were diagnosed as early as 1984the very beginning of the global AIDS crisis. Unlike most industrialised countries, where prevention programmes had quickly been implemented, the lack of funds and regulatory capacity was the reason why in Thailand, at the onset of the 1990s, the epidemic seemed to have gotten out of control with 140,000 new infections per year. It was only due to a concerted effort of key ministries, NGOs, the media, communities, the private sector and the police that Thailand could evade an existential health crisis. However, although Thailand managed to reduce the infection rate dramatically within only a few years, the high infection rates of the 1990s had left more than 600,00o people infected with HIV, with the immediate need to get access to medical care. 
Around the mid-1990s, several anti-retroviral substances were found to suppress the reproduction of the virus inside the human body. Although the infection could not be cured, a continuous treatment with a combination of two to three anti-retroviral drugs can stabilize the condition of a patient for many years. This treatment soon became the standard treatment in most countries in the North and changed the perception of HIV and AIDS from a fatal diagnosis to a chronic disease like diabetes. In the countries of the Global South, however, anti-retroviral medication was not available. Since anti-retroviral treatment requires a developed medical infrastructure, regular blood checks and strict adherence, it was long seen as not feasible in the Global South. Apart from technical and infrastructure problems, the most serious obstacle for access to drugs was their price. Since many of the anti-retroviral drugs were available only as brand-name drugs, the cost of imported drugs was too high for most developing countries. In 1995, a pilot project of the World Bank, the World Health Organisation and the Ministry of Public Health in Thailand came to the conclusion that treatment of HIV could not be implemented in Thailand since the 'cost [was] higher than the benefits' (Ford 2004).

The origins of TNP+, the Thai Network of People Living With HIV and AIDs, lie in Northern Thailand. The reason why this rural area is one of the hotspots of the Thai epidemic is due to the circular migration pattern of Thai internal labour migrants. Young men and women from the provinces regularly migrate to find seasonal jobs in the urban centres of Bangkok, Chiang Mai or Pattaya. Many of those working in the lucrative sex business of the touristic areas got infected and brought back the virus to the countryside upon returning home.

The denial of access to medication for PLHA, some of whom had already been taking part in pilot projects for anti-retroviral treatment and were sent away after the project ran out, triggered a process of self-organization. According to Wirat Purahong, president of TNP+, the founding of TNP+ was an act of self-empowerment (Lyttleton, Beesey and Sitthikriengkrai 2007). Central to this empowerment was the establishment of so called Buyers' Clubs - semi-formal structures where PLHA organized the procurement and allocation of life-saving drugs in cooperation with NGOs like Doctors without Borders. The first club was established in a hospital in Rayong at the initiative of a nurse working for Doctors without Borders. The group of PLHA was given a room inside the hospital where they could store and administer a stock of essential drugs, some of which had to be imported illegally from India since they were only available as brand-name drugs that were prohibitively expensive in Thailand (Sripen and Gill 2008:333-334). At its height, twenty-one branches of the Buyers' Club operated throughout Thailand and secured the supply of 
drugs for more than 1,000 patients (Niprapa et al., 2005:10), many of whom would have died without this support.

The co-operation between TNP+ and international NGOs like Doctors without Borders made Thai PLHA (People Living with HIV and AIDS) experts in the field of medical treatment, medical infrastructure and health politics. This engagement with state structures on a local level was crucial for the integration of anti-retroviral treatment into the framework of the newly established Thai universal healthcare system.

For decades, Thai unions and social movements had been demanding improvements in healthcare provision. However, in order to provide for an investment-friendly climate, earlier governments had persistently left this field unregulated (Amara, Rakawin and Nauemol 2002). The result was that until the late 199os, the Thai health insurance system consisted of several different schemes and was highly fragmented: in 1974, a tax-funded healthcare scheme for civil servants had been introduced. During the 1980s, several local insurance schemes and special programmes for the poor had been introduced. A first major reform step was taken with the Social Security Act of 1992 that introduced a corporatist tripartite insurance system tied to formal working contracts. Despite the great number of different programmes, by the mid-199os, more than thirty percent of the population was left without health insurance and this number dramatically increased during the Asian Crisis, as more and more people lost their formal employment and had to resort to (unprotected) informal work (Schramm 2002).

Against this backdrop, Thaksin Shinawatra introduced a tax-financed universal healthcare programme overnight. In 2001, Thaksin had won the general elections with a great majority. One of his central promises was to lift Thailand out of the economic stagnation that followed the Asian financial crisis of 1997. He pursued a dual programme of neo-liberal privatization and, at the same time, investment programmes for infrastructure and the introduction of a new healthcare scheme.

Under the so-called 30-Baht programme, every Thai citizen could register at a hospital and - with a fee of 30 Baht per visit - get medical treatment (Hughes and Songkramchai 2007). The neo-liberal opposition harshly criticized the programme as populist and not sustainable since its financial basis was not solid. Some patient groups criticized it for its poor quality. However, in terms of citizenship, it was revolutionary. Instead of a number of different targeted programmes, which addressed individual groups and led to a highly fragmented system of healthcare, the new programme formulated and implemented a universal right to healthcare that was tied to Thai citizenship. 
Somewhat in contradiction to its principle of universality, though, treatment of HIV was not included in the programme when it was first implemented. The reason was that there were doubts about the programme's budgeting, especially because the costs for anti-retroviral medication were expected to be incalculable due to the high prices of the drugs, the large number of infected people and the need for life-long medication of each patient. Here, the commitment of local PLHA groups came into play. With their experiences of self-organizing in Buyers' Clubs, the HIV groups were able to argue on the basis of the prospective price development of Indian generics that, in principle, a treatment scheme was possible. In October 2001, the Government Pharmaceutical Organization - the state-owned pharmaceutical company - launched a fixed-dose combination of anti-retroviral drugs on the basis of patent-free substances (Sripen and Gill 2008; Ford et al., 2009). Under the pressure of political campaigns, the Ministry of Public Health finally agreed to include anti-retroviral medication in the universal access to healthcare policy. This process was completed in 2003 with the establishment of the National Access to Antiretroviral Programmes for People living with HIV/AIDS. PLHA were integrated into all relevant medical and political planning processes, such as those concerning the definition of the standards of treatment or budget allocation. Sripen and Gill, (2008) consider this step a change in quality as far as the cooperation between progressive ministerial bureaucracy and PLHA groups is concerned.

In terms of citizenship this development is remarkable. In many developing countries, HIV programmes have developed into parallel structures to public healthcare systems. In some poor areas, this has led to the paradox situation that healthcare for HIV positive people - because it is funded by foreign donors and run by international NGOS - is better than the public healthcare system and there are reports of people getting infected deliberately in order to access special support programmes. In Thailand, the establishment of Buyers' Clubs could also be seen as a parallel structure to provide access to drugs that were not available on a regular basis through the public institutions. However, these structures were integrated into and cooperated with public hospitals. Moreover, this parallel structure was always seen as provisional and was dissolved as soon as a new universal public scheme was established.

\section{Political Action and Citizenship: PLHA and Adversarial Legalism}

As smooth and cooperative as this process of establishing a public universal institution of HIV treatment might appear, the integration of HIV treatment 
into the universal health scheme on the basis of domestically produced generic drugs was the result of a highly contested process of political struggle and engagement of individuals and civil society groups (Ford, Wilson, Chaves, Lotowska and Kannikar 2007; Ford et al., 2009). The critical question was how to secure the production or import of generic anti-retroviral drugs. Under pressure from the us government, Thailand had reformed its patent laws as early as 1992. Under the new provisions, pharmaceutical substances were able to receive patent protection for twenty years, long before newly industrialized countries were obliged to implement these standards under the TRIPS treaty ${ }^{5}$ of the World Trade Organisation (Jiraporn 2005). When the Thai Ministry of Public Health was preparing the introduction of a triple therapy on the basis of generically produced didanosine in 1999, the patent holder, Bristol-Myers Squibb, intervened and prohibited the production (Weeraboon 2004). In turn, Bristol-Myers Squibb offered to sell didanosine to Thailand at a special price, which was still much higher than the generic drug would have cost.

Against this backdrop PLHA groups and NGOs called for compulsory licensing as a way to legalize generic production without the consent of the patent holder. Compulsory licensing is a tool that is explicitly allowed by the World Trade Organisation, especially in cases where health hazards have to be dealt with. However, due to the pressure from industrialized countries and pharmaceutical companies, no country in the developing world dared to make use of this flexibility (Ford, Onanong and Von Schoen Angerer 2004:56o). When the Government Pharmaceutical Organisation formally asked for compulsory licensing in order to be entitled to produce didanosine tablets in 1999, the Thai Ministry of Public Health denied the request.

When it became clear that the possibility of resorting to compulsory licensing was barred, PLHA groups decided to challenge the patent judicially for the first time. Flaws in the application process of the patent promised a chance to win against Bristol-Myers Squibb in court. Under the leadership of the Drug Study Group, an NGO comprised of committed pharmaceutical researchers, the AIDS Access Foundation and the Health and Development Foundation, a working group was formed that coordinated the cooperation of a broad network and prepared for the law suit. The Law Society of Thailand, a professional organization of lawyers in Thailand, provided a lawyer pro bono, and Doctors without Borders supported the coordination group with one full-time project manager (Weeraboon 2004; Ford et al., 2009). In May 2001, two PLHA, together

5 Trade Related Aspects of Intellectual Property Rights (TRIPS) is the treaty of the World Trade Organisation which defines the standards of patent protection for the wTo member countries. 
with the AIDS Access Foundation, filed a lawsuit against Bristol-Myers Squibb at the Central Intellectual Property and International Trade Court of Thailand. Instead of a judicial evaluation of procedural errors concerning the issuing of the patent, the litigation had to firstly evaluate whether patients could be accepted as litigants in patent disputes at all - a status commonly restricted to companies and countries (Weeraboon 2004:57; Ford et al., 2004:561).

Meanwhile, the Thai struggle against patents had become an issue at the World Trade Organisation Ministerial Conference in Seattle in December 1999, and the outrage over the effects of the restrictive interpretation of TRIPS (the patent treaty) was one factor that led to the historic collapse of the trade negotiations. In the same month, about hundred PLHA organized a protest camp in front of the Ministry of Public Health and became publically visible for the first time. At the 2001 ministerial conference in Doha, Qatar, which was overshadowed by the 9/11 terrorist attacks, the World Trade Organisation felt obliged to openly react to the critique of developing countries, NGOS and social movements and issued the so-called Doha Declaration, which re-affirmed the possibility of compulsory licensing as one aspect of legal flexibility of the patent agreement and also the fundamental right of patients to have access to treatment (WTO 2001).

In its first ruling in October 2002, the Thai court decided in favour of the litigants and explicitly accepted patients as plaintiffs. In addition, the court mentioned in its ruling that medical drugs are to be differentiated from other consumer goods in so far as the lack of access to drugs due to high prices violates the human right of access to healthcare (Ford et al., 2004:561).

The three plaintiffs have the right to pursue the case.... Medicine is one of the fundamental factors necessary for human beings, as distinct from other products of other inventions that consumers may or may not use for consumption.... Lack of access to medicines due to high price prejudices the human rights of patients to proper medical treatment.

WEERABOON 2004:57

To the same extent that this ruling was a novelty in the Thai jurisdiction, it set a precedent in worldwide trade and intellectual property rights litigation. Most importantly, however, it meant a step in the direction of a specific kind of citizenship interpretation. With this ruling, Thai PLHA were officially accepted and established as rights-bearing subjects who are able to utilize the human right to access to medication as a legal tool. Very much like the precedent set by the constitutional court of South Africa in its ruling on social rights such as access to water and housing (Jones and Stokke, 2005), the Thai ruling had not 
only an impact on the domestic legal system but also on a global level (Weeraboon 2004). Moreover, it meant a shift in the legal consciousness of the PLHA and activists involved in the process.

Before this time, NGOs were only involved with campaigning and training, but with this issue, I had to familiarize myself with anti-retroviral medicines, patents, TRIPS and WTO

SANGSIRI tREEMANAKa, coordinator of Access Foundation, cited in Weeraboon 2004:46

We need to catch up on the legal details. We must know what academics mean.

NIMIT TIEN-UDOM, Aids access manager

What we can see are signs of the emergence of a rights-based concept of citizenship. Just as in the Us, in Thailand, too, adversarial litigation appeared as a promising tool to achieve a change in public policy. However, in so far as key figures of the campaign were highly educated NGO workers and academics, one can argue that this rights-based pattern of citizenship was linked to a specific social class. ${ }^{6}$ In the same vein, we see the influence of international actors NGOs such as Doctors without Borders and other actors of the globalization critical movement who were acquainted with Us-American-style patterns of political campaigns and introduced them in Thailand.

However, unlike the movements in South Africa where the entire PLHA movement centred very much on legal action in several court cases (Bilchitz 2003; Jones 2005), for Thai PLHA, the court case was merely an episode. In fact, the working group under the leadership of the Drug Study Group used the first verdict and its reference to the Doha Declaration to prepare for a second

6 I am grateful to Henk Schulte Nordholt for pointing out this connection to class. There is clearly a class issue in Thailand which deserves further study. Especially because 'rights talk' seems to be identified as an element of middle and upper-class life style in more and more countries around the world. The rejection of 'rights talk' - including the rejection of minority rights and other liberal rights - serves as a populist foundation for right-wing mobilization. As I have argued earlier in this chapter, the dichotomy between middle and upper-class rights consciousness and lower class right-wing rejection of rights talk is not borne out in Thailand's split between Yellow and Red Shirts. The Red Shirts are no right-wing movement, and the Yellow Shirts are no liberals. However, in Hungary, India, Ukraine and many other countries, where liberal rights are identified as part of a neo-liberal economic project of domestic middle and upper classes, anti-neo-liberal movements often take the shape of rightwing movements who reject political liberalism. 
lawsuit, which no longer aimed at procedural errors but at the legitimacy of the patent itself. However, in order to prevent another ruling that might constitute a precedent, in late 2003, Bristol-Myers Squibb offered an out-of-court settlement to the plaintiffs. TNP+ and the Drug Study Group, tired of years of judicial dispute during which several members of the PLHA groups had already died - some due to the lack of access to medical drugs - accepted the settlement (Weeraboon 2004:64-6).

\section{Political Action and Citizenship: Mobilization on the Streets}

Despite this partial success, access to anti-retroviral medication was only secured for a short period of time and it was clear that the problem of patent protection and intellectual property rights would soon re-occur in an even more serious form.

The anti-retroviral medication provided for by the Government Pharmaceutical Organisation was mainly based on a combination of so-called first-line drugs, that is drugs that were developed at an early stage of the HIV epidemic and for which the patent protection had already expired. In the course of the medical treatment, however, the virus inevitably develops resistance, meaning that at later stages of treatment, certain first-line substances have to be substituted for so called second-line drugs. Since these drugs result from relatively recent medical research, most of them are protected for at least another five years under legally indisputable patents. Another obstacle was that the transitional arrangements for the implementation of the TRIPS provisions for middle-income countries expired in 2005. This meant that countries like India had to fully comply with higher patent protection standards by that date. The direct consequences were that the import and export of generic drugs was hindered and competition between different generic producers, a main trigger for cheap prices, was undermined.

As with other countries with a considerable population of PLHA, the new development posed serious problems for Thailand: without access to cheap, generic versions of second-line anti-retroviral drugs, the whole project of providing access to anti-retroviral medication under the universal coverage scheme would become unaffordable. To make things worse, in 2005, the administration of the newly re-elected government of Thaksin Shinawatra spurred up their engagement to negotiate a Free Trade Agreement with the US. As with most bilateral trade agreements, the Thai-US Free Trade Agreement contained so-called 'TRIPS plus' provisions which went beyond the patent agreement of 
the World Trade Organisation, guaranteed longer periods of patent protection and excluded flexibilities such as compulsory licensing.

This is the scenario that forced PLHA to take political action again. The coalition they joined, however, was quite different from the network that was behind the courts cases. On the basis of the common threat of the free trade agenda being pushed by the World Trade Organisation on an international level and by the us-Thai Free Trade Agreement on a bilateral level, TNP+ became a founding member of a network named FTA Watch. Here they joined forces with farmers' organizations who feared the ruinous competition of us-American farmers as well as with consumer groups who feared further deregulation and lowering of product standards (Chanida and Bamford 2005). From a Western perspective, a coalition between small-scale farmers and PLHA seems highly improbable. However, in Thailand, it was not only a short-term strategic cooperation, but a long-term coalition. One reason might be that, differently from the West where HIV is a predominantly urban phenomenon, the hot spots of HIV in Thailand have long been in rural areas due to cyclic migration of sex workers.

In December 2005, FTA Watch mobilized to protest against the negotiation round of the World Trade Organisation in Hong Kong. There, TNP+ and Thai farmers joined forces with farmers from Korea who had the reputation of being very disciplined, radical and militant. Their protest included ritual marches in military-like formations, a strict choreography of kneeling down on the pavement and bowing to the ground and eventually, militant action against the barricades of the police. One action that got a lot of media attention was the attempt to use swimming vests and swim over to the offshore convention centre where the WTO ministerial conference was being held. Together with the Korean farmers, Thai PLHA were detained by the Chinese police and suffered severe human rights violations in prison (Hong Kong People's Alliance on wTO 2006). A few weeks later, in January 2006, FTA Watch took to the streets of Chiang Mai where the final negotiations on the Us-Thai FTA were being held. About 10,000 farmers and PLHA staged a protest using Korean-style choreography and eventually caused the breakdown of the meeting. This political success was a milestone in the history of the network and it is one of the foundations of the close cooperation between Thai PLHA and small-scale farmers. The strategy which FTA Watch used in Bangkok in February 2013 to protest against the EU-Thai FTA - mentioned in the introduction to this chapter - is a reminiscence to the events in 2005/2006.

The year 2006 also saw the emergence of a first wave of anti-Thaksin protests in Bangkok. When they first mobilized, the People's Alliance for 
Democracy - a predecessor of what later became the royalist-conservative Yellow Shirts - managed to draw together various movements and NG OS. In order to stop Thaksin's free trade policy, FTA Watch also agreed to join the protests. ${ }^{7}$ With this move, the protests gained momentum and legitimacy and drove the Thaksin government into the defensive (Pye and Schaffar 2008). In the resulting political stalemate, and due to increasingly radicalized and undemocratic parts of the People's Alliance for Democracy, the military eventually moved in, staged a coup d'état and removed Thaksin from office (Hewison 2008).

Generally speaking, the coup of 2006 meant a severe setback for the democratization process in Thailand: a months-long curfew, the introduction of new and strict internet censorship, and a gross violation of human and political rights. Moreover, the violent interruption of the political process deepened the emerging divide in Thai society, brought Thailand close to civil war and caused the death of many people in the subsequent protests. In the short-term, however, the installation of a military-sponsored government was a window of opportunity for two major achievements for TNP+ and FTA Watch.

Firstly, the new minister of health, Monkhol na Sonkhla, issued compulsory licences on five essential drugs for treating HIV, cancer and heart diseases in December 2006 and January 2007. This step was met with fierce criticism from the side of international pharmaceutical companies, but was soon copied by other countries with similar problems such as Brazil and thus set new global standards in the interpretation of TRIPS flexibilities (Schaffar 2014).

Secondly, and equally important, FTA Watch managed to take an active position during the drafting process of a new constitution in 2007. The militarysponsored drafting committee had a contradictory task to fulfil. On the one hand, the royalist-conservative elites wanted to make sure that Thaksin could not come back to power despite his unbroken popularity. On the other hand, the military had to show their intention to introduce a better democratic system than Thaksin's allegedly corrupt system. FTA Watch could use the quest for democratic legitimacy of the drafting committee and lobbied successfully for provisions. However, contrary to what one might expect from a rights-based perspective, the member groups of FTA Watch did not lobby for the codification of specific rights - such as the right to access to drugs or medical care, the

7 As mentioned earlier in this chapter, the PLHA groups and small scale farmers were not directly linked to the Yellow - Red divide. However, since FTA Watch used the mobilization of the anti-Thaksin movement in 2006 to push for their cause, they are considered as Yellowish, especially by activists from the Red camp. As for the content of their claims, the rejection of a rights-based approach and the insistence on parliamentary processes would rather be an issue raised by the Red Shirts. 
right to land or indigenous rights that have been used in other countries to fight for access to land and protection of small scale farming (Rachman 2013; Bencharat 2013). Instead, FTA Watch concentrated on one single provision: an article that guaranteed that international treaties have to be discussed in parliament and must be publicly disclosed during the negotiation process. This provision was taken into the constitution of 2007 as Section 190 and it was another milestone of the political success of FTA Watch. The central demand of the protesters in Bangkok in 2013 to publicly disclose the negotiation papers of the EU-Thai Free Trade Agreement - mentioned in the introduction to this chapter - refers to this provision. In a global perspective, Section 190 is a unique article which was much acclaimed by international NGOS and discussed as an example for the strategies to be employed in Europe as well. ${ }^{8}$

\section{Towards Republican Citizenship in the Global South}

In 2004, TNP+ abandoned the legal arena. The experience of their court case against Bristol-Myers Squibb had shown that contrary to the expectation of a rights-based development paradigm, claiming rights in court did not result in a sustainable solution to the problem of securing access to anti-retroviral drugs. The right to access to healthcare was under permanent threat, especially due to the free trade agenda on the national and international level. In the course of the years 2003/2004, it became clear that the power relations and interests of transnational pharmaceutical companies that were behind this agenda had to be challenged by different means. The crafting of a broad and powerful coalition between the various groups affected by the free trade policy, however, made it necessary to move beyond particularistic claims for single issues and to generalise political demands. During the years 2004 through 2006, FTA Watch facilitated a close communication between the very different groups and whenever any group was about to publish a statement on trade issues, the content was communicated and discussed with all other members of the network.

This generalization of political claims and the integration into a broader movement that went beyond health groups corresponds to the concept of identity of TNP+. For a long time, the (international) perception of HIV in Thailand was dominated by Buddhist charity institutions like the so called AIDs temple,

8 At the occasion of the Asia Europe Peoples' Forum in Brussels in 2010, social movements and NGOs working on free trade agreements in different countries repeatedly referred to Section 190 of the Thai Constitution. 
Wat Prahbat Namphu, a hospice in Lopburi where AIDS patients seek refuge in the final stages of their disease to receive medical treatment or simply to die. The handling of the disease is embedded in a religious context and draws on the widespread believe that an HIV infection is a consequence of bad karma (Ross, Wilaiphan Draucker and Tatirat 2007). Enduring the suffering and using the final days of their lives to pray and earn merit serves as a strategy for coping with the disease and achieving better karma for the next life.

TNP+, however, rejects this charity-based, Buddhist approach with its focus on suffering, death and rebirth. Instead, TNP+ promotes a bio-medical approach, stressing that AIDS is caused by a viral infection and that HIV positive people - under the condition that they have access to treatment - are not closer to death than anyone else. The name of the group TNP+ 'People LIVING with HIV and AIDs' is a programmatic statement.

Rejecting a religious concept of bad karma, however, does not mean that TNP+ took the same road as Treatment Action Campaign in South Africa who pursued the strategy to turn their infection status into a 'batch of pride' to fight discrimination (Robins 2004 2006). The 'positive identity' that is promoted by $\mathrm{TNP}+$ is rather centred on the concept of normalcy. This is best mirrored in the material produced by TNP+ for public education. In the short films and video clips such as My Positive Life, TNP + features the everyday life of common people - a lady working in an office, a farmer, a young man courting his girlfriend, et cetera. The short film My Dream features a young man who dreams of becoming a soldier but is confronted with a positive result of an HIV test. In all these films, there is almost no mention of how people got infected but the focus is rather on how to cope with the infection in daily life. The main message is clear: if people have access to anti-retroviral drugs, and if discrimination is overcome, PLHA can lead a normal life as farmers, soldiers, secretaries, and thus serve society.

This stress on normalcy and on participating in society is in stark contrast to what Nguyen (2010) and Robins (2004) report on the transformation of HIV positive people in Western Africa or South Africa. What Nguyen calls 'therapeutic citizenship' is the result of a near-death experience that many HIV-positive people in West Africa share. Those patients who - after having developed serious AIDS symptoms - manage to get chosen to participate in an anti-retroviral treatment programme, report how this experience of being rescued turned them into politically aware citizens whose new life is centred around the question of fighting for access to the drugs, including political activities to secure anti-retroviral treatment programmes. In the case of South Africa, this new form of citizenship is closely connected to the identity of turning their HIV status into a 'batch of pride' and rights-claiming action in court. 
In Thailand, on the other hand, TNP+ stresses that PLHA are just ordinary people - albeit ready to take militant action if they find themselves confronted with interests of pharmaceutical companies or unco-operative bureaucrats in the Ministry of Public Health.

PLHA in Thailand, in their struggle for access to anti-retroviral drugs and in their everyday routines of interaction with state authorities, show a specific type of citizenship. This pattern is neither based on adversarial rights-claiming in court, nor a 'muddling through' on the basis of clientelist or informal political action. Rather than a particularistic claim to rights, they base their engagement on generalised political claims. This became clear in their positioning towards the EU-Thai FTA in 2013 which was mentioned in the introduction to this chapter. FTA Watch did not oppose free trade as such on the ground that it has a negative impact on PLHA and farmers. Rather, they drew on Article 190 of the constitution and demanded that an FTA - as much as all international contracts with impact on public policy - has to be disclosed to the public. This reveals a high confidence that a public debate will yield the right decision - a kind of confidence in the public sphere that is reminiscent of Habermas' republican concept of deliberative democracy and the belief in 'the non-coercive coercion of the better argument' (Habermas 1990:132).

Any concept of citizenship in postcolonial countries that operates with the dichotomy of a rights-conscious, urban middle class versus a clientelist, rural, poor population runs into difficulties with regard to the dynamics of citizenship in Thailand. Firstly, it seems that focusing on this dichotomy obscures the fact that a rights-based interpretation of citizenship is not so much the unmarked case of 'Western' citizenship but rather a generalization of us-American exceptionalism, which is contested in the Global South as much as in the Global North. Secondly it obscures the dynamic, innovative and democratic patterns of citizenship in postcolonial countries, such as FTA Watch's successful lobbying for Section 190 in the Thai Constitution, which guarantees political participation in the republican sense of citizenship.

\section{References}

Amara Pongsapich, Rakawin Leechananichphan and Nauemol Bunjongjit (2002). Social Protection in Thailand. In E., Adam, M. von Hauff, and M. John (eds.), Social Protection in Southeast and East Asia. (pp. 313-362). Singapore: Friedrich Ebert Foundation.

Bencharat Sae Chua (2013). Rights Claims and Strategic Use of Culture to Protect Human Rights: The Community Forest Movement in Thailand. In B. Coeli (ed.), 
Rights to Culture. Heritge, Language, and Community in Thailand. (pp. 85-114). Chiangmai: Silkworm.

Berenschot, W., Schulte Nordholt, H. \& Bakker, L. (2017). Citizenship and Democratization in Postcolonial Southeast Asia. In: W. Berenschot, H. Schulte Nordholt, \& L. Bakker (Eds.) Citizenship and Democratization in Southeast Asia (pp. 1-32). Leiden: Brill Publishers.

Bilchitz, D. (2003). South Africa: Right to health and access to HIV/AIDS drug treatment. International Journal of Constitutional Law, 1(3), 524-534. doi: 10.1093/icon/1.3.524.

Brand, U., Görg, C. \& Wissen, M. (2011). Second-Order Condensation of Societal Power Relations: Environmental Politics and the Internationalisation of the State from a Neo-Poulantzian Perspective. Antipode 43(1), 149-175. doi: 10.1111/j.1467-8330.2010.00815.x.

Callahan, W.A. (2005). The Discourse of Vote Buying and Political Reform in Thailand. Pacific Affairs, 78(1), [Democratization and Communication in Asia] pp. 95-113. doi: $10.2307 / 40023443$.

Chanida Chanyapate Bamford \& Bamford, A. (eds.). (2005). Free Trade Agreements and Their Impacts on Developing Countries: The Thai Experience. Bangkok, FTA Watch.

Chatterjee, P. (2004). The Politics of the Governed: Reflections on Popular Politics in Most of the World. New York: Columbia University Press.

Demirović, A. (2011). Materialist State Theory and the Transnationalization of the Capitalist State, in: Antipode 43(1), 38-59. doi: 10.1111/j.1467-8330.2010.00810.x.

Donttradeourlivesaway (2013a). CSO's Thailand-EU FTA campaign kick-off. http:// donttradeourlivesaway.wordpress.com/2013/02/28/csos-thailand-eu-fta-campaign -kick-off/.

Donttradeourlivesaway (2013b). Civil Society's protest against the Thai-Eu FTA. http:// donttradeourlivesaway.wordpress.com/2013/03/o1/civil-societys-protest-against -the-thai-eu-fta/.

Ebenau, M. (2012). 'Recht und Entwicklung' bei der Weltbank: Eine Kritik. Peripherie, 125(32), 43-66. http://www.zeitschrift-peripherie.de.

Engel, D.M. \& Engel, J.S. (2010). Tort, Customs, and Karma. Globalization and Legal Consciousness in Thailand. Stanford: Stanford University Press.

Ford, N. (2004,). Patents, Access to Medicines and the Role of Non-Governmental Organisations. Journal of Generic Medicines, 1(2), 137-145. doi: 10.1057/palgrave. jgm.4940005.

Ford, N., Wilson D., Onanong Bunjumnong, \& von Schoen Angerer, T. (2004). The role of civil society in protecting public health over commercial interests: lessons from Thailand. The Lancet 363:56o-563. doi: 10.1016/So140-6736(04)15545-1.

Ford, N., Wilson, D., Chaves, G.C., Lotowska, M. \& Kannikar Kijtiwatchakul (2007). Sustaining access to antiretroviral therapy in the less-developed world: Lessons from Brazil and Thailand. AIDS 21(suppl 4), 21-29. doi: 10.1097/01.aids.0000279703.78685. a6. 
Ford, N., Wilson, D., Cawthorne, P., Aree Kumphitak, Siriras Kasi-Sedapan, Suntharaporn Kaetkaew, Saengsri Teemanka, Boripat Donmon, \& Chalerm Preuanbuapan (2009). Challenge and Co-operation: Civil Society Activism for Access to HIVTreatment in Thailand. Tropical Medicine and International Health 14(3), 258-266. doi: 10.1111/j.1365-3156.2009.02218.x.

Habermas, J. (1990). Moral Consciousness and Communicative Action. Cambridge, MA: M.I.T. Press.

Hewison, K., (2008). A book, the king and the 2006 coup, Journal of Contemporary Asia, 38(1), 190-211. doi: 10.1080/00472330701652026.

Hong Kong People's Alliance on WTO (2006). Human Rights Violations during the Policing, Arrests, and Detentions during the WTO Protests in Hong Kong, December 2005 (Submission to the 86th Session of the U.N. Human Rights Committee: Consideration of the Second Report of the Hong Kong Special Administrative Region of the People's Republic of China in light of the International Covenant on Civil and Political Rights, Prepared by: Hong Kong People's Alliance on WTO Asian Human Rights Commission, 15 3. 2006), http://www.ahrchk.net/pdf/HKPA_AHRC-UNReport2oo6. $\operatorname{pdf}(25 \cdot 4 \cdot 2006)$.

Hughes, D. \& Songkramchai Leethongdee (2007). Universal Coverage in the Land of Smiles: Lessons from Thailand's 30 Baht Health Reform. Health Affairs, 26(4), 999-1008. doi: 10.1377/hlthaff.26.4.999.

Isin, E.F. \& Turner, B.S. (2002). Citizenship Studies: An Introduction. In Engin F. Isin \& Bryan S. Turner (eds.) Handbook of Citizenship Studies. (pp. 1-10). London: Sage.

Jiraporn Limpananont (2005). Impact of US-Thailand FTA in Access to Medicines in Thailand. In Chanida Chanyapate Bamford and A. Bamford (eds.), Free Trade Agreements and Their Impacts on Developing Countries: The Thai Experience. (pp. 59-74) Bangkok, FTA Watch.

Jones, P.S. (2005). 'A Test of Governance': Rights-Based Struggles and the Politics of HIV/AIDS in South Africa. Political Geography 24(4), 419-447. doi: 10.1016/j. polgeo.2004.10.012.

Jones, P. \& Stokke, K. (eds.) (2005). Democratising Development. The Politics of SocioEconomic Rights in South Africa. Boston: Martinus Nijhoff Publishers.

Kagan, R.A. (2003). Adversarial Legalism. The American Way of Law. Cambridge: Harvard University Press.

Kelemen, R.D. (2011). Eurolegalism: The Transformation of Law and Regulation in the European Union. Harvard University Press.

Kelemen, R.D. \& Sibbitt E.C. (2004). The Globalization of American Law. International Organization, 58(1), 103-136. doi: http://dx.doi.org/10.1017/Soo20818304581043.

Klinken, G. van (2009). Patronage Democracy in Provincial Indonesia. In O. Törnquist, N. Webster \& K. Stokke (eds.) Rethinking Popular Representation. New York: Palgrave Macmillan. 
Lyttleton, C., Beesey A. and Sitthikriengkrai, M. (2007). Expanding Community through ARV Provision in Thailand. AIDS Care, 19:S1, 44-53. doi:10.1080/09540120601114659.

Marshall, T.H. (1950). Citizenship and Social Class. Cambridge UK: Cambridge University Press.

Merry, S.E. (2001). Spatial Governmentality and the New Urban Social Order: Controlling Gender Violence Through Law. American Anthropologist, 103(1), 16-23. doi: 10.1525/aa.2001.103.1.16.

Merry, S.E. (2006a). Transnational Rights and Local Activism: Mapping the Middle. American Anthropologist, 108(1), 38-51. doi: 10.1525/aa.2006.108.1.38.

Merry, S.E. (2006b). Human Rights and Gender Violence. Translating International Law into Local Practice. Chicago: University of Chicago Press.

Munger, F. (2006/2007). Culture, Power, and Law: Thinking About the Anthropology of Rights in Thailand in an Era of Globalization. New York Law School Law Review 51, 817-838. http://connection.ebscohost.com/c/speeches/ 25292716/culture-power-law-thinking-about-anthropology-rights-thailand-era-globalization.

Munger, F. (2007). Constitutional Reform, Legal Consciousness, and Citizen Participation in Thailand. Cornell International Law Journal 40, 455-475. http:// scholarship.law.cornell.edu/cilj/vol4o/iss2/5.

Nguyen, V.-K. (2010). The Republic of Therapy: Triage and Sovereignty in West Africa's Time of AIDS. Durham and London: Duke University Press.

Niprapa Kreudhutha, Boripat Donmon, Kamon Upakaew, Cawthorne, P., Onanong Bunjumnong, Wilson, D., Ford, N. (2005). Experience of a Community-Based Antiretroviral Buyers' Club in Thailand. Essential Drugs Monitor 34, 10-11. doi: 10.1111/j.1365-3156.2009.02218.x.

Nowak, Manfred; Karolina M. Januszewski and Tina Hofstätter (2012): All Human Rights for All. Vienna Manual on Human Rights. Wien: Intersentia/Neuer Wissenschaftlicher Verlag.

Pongphon Sarnsamak (2013a). Thai-EU trade talks could kill cheap life-saving medicines. The Nation, September 3, 2013. http://www.nationmultimedia.com/ national/EU-trade-talks-could-kill-cheap-life-saving-medici-30214017.html.

Pongphon Sarnsamak (2013b). Protest in Chiangmai against THai-EU FTA. The Nation, September 18, http://www.nationmultimedia.com/national/Protest-in-Chiang-Mai -against-Thai-EU-FTA-30215106.html.

Pye, O. \& Schaffar, W. (2008). The 2006 Anti-Thaksin Movement in Thailand: An Analysis. Journal of Contemporary Asia, 38(1), 38-61. doi: 10.1080/0047233 0701651945 .

Rachman, N.F. (2013). Undoing Categorical Inequality. Masarakat Adat, Agrarian Conflicts, and Struggle for Inclusive Citizenship in Indonesia. Paper presented at the KITLV, Leiden, 13 June 2013. 
Robins, S. (2004). 'Long Live Zackie, Long Live': AIDS Activism, Science and Citizenship after Apartheid. Journal of Southern African Studies, 30(3), 651-672. doi: 10.1080/0305707042000254146.

Robins, S. (2006). From 'rights ' to 'ritual': AIDS activism in South Africa. American Anthropologist 108(2), 312-323. doi: 10.1525/aa.2006.108.2.312.

Robins, S. \& Lieres, B. von (2004). AIDS Activism and Globalization from Below: Occupying New Spaces of Citizenship in Post-Apartheid South Africa. IDS Bulletin 35(2), 84-9o. doi: 10.1111/j.1759-5436.2004.tboo125.x.

Robins, S., Cornwall, A. \& Lieres, B. von, (2008). Rethinking 'Citizenship' in the Postcolony.Third World Quarterly, 29(6), 1069-1086, doi:10.1080/01436590802201048.

Ross, R. Wilaiphan Sawatphanit, Draucker, C.B., Tatirat Suwansujarid (2007). The lived experiences of HIV-positive, pregnant women in Thailand. Health Care For Women International 10, 28(8), 731-744. doi: 10.1080/07399330701465218.

Schaffar, W., (2011) Widerständige ländliche Bewegungen und die „Kunst, nicht regiert zu werden. In M. Bruch, W. Schaffar, P. Scheiffele (eds.) Organisation und Kritik. (pp. 137-169). Münster: Dampfboot.

Schaffar W. (2014): Schwellenländer als neue Akteure globaler Normsetzung am Beispiel des Patentschutzes auf Medikamente. In A. Nölke, C. May \& S. Claar (eds.) Der Aufstieg der großen Schwellenländer in der Weltwirtschaft: Ein Handbuch. (pp. 339-355). Wiesbaden: Springer VS.

Schramm, B. (2002). Sozialpolitik in Thailand. Die Entwicklung eines Wohlfahrtsstaates zwischen Paternalismus und Moderne. [Mitteilungen des Instituts für Asienkunde Hamburg, Band 347]. Hamburg.

Schulte Nordholt, H. (2011). Decentralization and Democracy in Indonesia: Strengthening Citizenship or Regional Elites?. In D. Robison (ed.), Handbook of Southeast Asian Politics. (pp. 229-241). Oxford: Routledge.

Schulte Nordholt, H. \& Klinken G. van (eds.). (2007). Renegotiating Boundaries: Local Politics in post-Suharto Indonesia. Leiden: KITLV Press.

Smith, R.M. (2002). Modern Citizenship. In: Engin F. Isin \& Bryan S. Turner (eds.). Handbook of Citizenship Studies. (pp. 105-116), London: Sage.

Somchai Phatharathananunth (2006). Civil Society and Democratization. Social Movements in Northeast Thailand. Copenhagen: NIAS Press.

Spivak, G.C. (1985). The Rani of Simur. In F. Barker et al., (eds.). Europe and its Others. Vol. 1., (pp. 247-272). Colchester: University of Sussex.

Sripen Tantivess \& Gill, W. (2008). The role of state and non-state actors in the policy process to the scale-up of antiretroviral therapy in Thailand. Health Policy and Planning 23(5), 328-338. doi: 10.1093/heapol/czno23.

The Asia Foundation (2013). Profile of the Protestors. A Survey of Pro and Anti-Government Demonstrators in Bangkok on November 30, 2013. Bangkok. http://asiafoundation.org/resources/pdfs/FinalSurveyReportDecember2o.pdf. 
Thongchai Winichakul (2008a). Nationalism and the Radical Intelligentsia in Thailand. Third World Quarterly 29(3), 575-591. doi: 10.1080/01436590801931520.

Thongchai Winichakul (2008b). Toppling democracy. Journal of Contemporary Asia, 38(1), 11-37. doi: 10.1080/00472330701651937.

Tilly, C. (1995). Citizenship, Identity and Social History. International Review of Social History, 4o(SupplementS3), 1-17. doi: 10.1017/Soo20859000113586.

UN (1979). Convention on the Elimination of All Forms of Discrimination against Women (CEDAW) [adopted on 18 December 1979]. http://www.un.org/womenwatch/ daw/cedaw/

UN (2009). Legal empowerment of the poor and eradication of poverty. Report of the Secretary-General, A/64/133. http://www.un.org/esa/socdev/documents/reports/ Legal\%2oempowerment\%2oof\%2othe\%2opoor.pdf

Walker, A, (2012). Thailand's Political Peasants. Power in the Modern Rural Economy. Madison: University of Wisconsin Press.

Weeraboon Wisartsakul (2004). Civil Society Movement to Revoke the Thai Patent on ddI, Bangkok: Medecins sans frontiers - Belgium (MSF-B).

WTO (2001). Declaration on the TRIPS Agreement and Public Health. [adopted on 14 November 2001], WTO Ministerial Conference, Fourth Session, Doha, 9-14 November 2001, WT/MIN(01)DEC/. 


\title{
Defending Indonesia's Migrant Domestic Workers
}

\author{
Mary Austin
}

On the morning of 8 June, 2009, Siti Hajar, a thirty-three-year-old Indonesian woman from a village in Garut, West Java, staged a daring escape from the house in Kuala Lumpur where she had been employed as a migrant domestic worker for three years. She used an iron rod to prise open the grille on the front gate and called to a neighbour who helped her find a taxi to the Indonesian embassy. There she told officials that her employer, a Malaysian widow and mother of two, had repeatedly beaten her with a cane and even poured boiling water over her. She was owed thirty-four months' wages. Her meals were meagre, mainly consisting of plain rice twice a day, and sometimes she had been forced to eat pork. Kept as a prisoner in the house, she had tried to run away several times before without success.

A few days after her escape the Jakarta Post published a photograph of Siti sitting up in her hospital bed in the University of Malaya Medical Centre where she was being treated for her injuries. A diminutive figure with her hair loose and wearing a hospital-style gown, Siti is flanked by two men standing at her bedside. One is the smartly suited figure of the Indonesian ambassador to Malaysia, Da'i Bachtiar, with his head slightly bowed and wearing an expression of grave concern. The second is a journalist who is filming and recording the scene. Siti herself is shown speaking on a mobile phone. The news report accompanying the picture explains that she was using the ambassador's phone to receive a direct call from no less than the president of Indonesia, who promised her the government would do 'whatever was necessary' to seek justice for her and ensure such abuses did not happen again. Siti herself spoke of how she wished to return home, but despite her sufferings, did not rule out the possibility of seeking work in Malaysia again. ${ }^{1}$

Pictures of Siti Hajar circulated nationally and internationally, reaching TIME magazine by 28 July (Thomas 2009). Portrayals of her conformed to the paradigm of the migrant domestic worker as a dependent female victim. ${ }^{2}$

1 Story reconstructed from news reports published on 10 and 12 June, available at http://wwwthe jakartapost.com/news/2009/06/10/siti-hajar-i-want-forget-hell.htmlandwww:thejakartapost .com/.../sby-calls-justice-maid-abuse-case.htm, accessed 3 September 2013.

2 For an influential critique of the construction of women in the 'Two-Thirds' world as dependent victims, see Chandra Mohanty's essay 'Under Western Eyes', in Mohanty, C. (2003) Feminism Without Borders Durham N.C. and London: Duke University Press.

(C) MARY AUSTIN, 2017 | DOI 10.1163/9789004329669_012

This is an open access chapter distributed under the terms of the CC-BY-NC-ND License. 978-90-04-32966-9 
The part of her story that was perhaps overlooked was her affirmation that she might return to Malaysia. This suggests that to Siti, as an impoverished divorced woman and mother, Indonesia seemed to have little or nothing to offer. It is also an unequivocal statement of her sense that she has the right to work and make her own decisions about her future.

In late June 2009, however, following a public outcry about Siti Hajar's experiences, Indonesia imposed a moratorium on sending domestic workers to Malaysia, making it impossible for women like Siti to access this work legally. In July the government began discussions with Malaysia to agree a new Memorandum of Understanding (MOU) setting out domestic workers' terms and conditions (Maulia 2009). Despite government and migration industry optimism that the matter would be settled quickly, negotiations went on for three years, generating a large amount of media coverage and public debate. Migrant worker NGOs seized the opportunity to use the media to mobilize public opinion in support of migrant domestic worker rights.

In so doing, NGOs reflected the universalist standpoint enshrined in the Beijing Declaration, which asserted that 'women's rights are human rights. ${ }^{3}$ It was crucial to 'move beyond' the nation-state, since both sending and receiving states in Southeast Asia had proved reluctant to act on behalf of migrant women (Piper 2003: 42). Feminist citizenship theorist Ruth Lister suggests that fewer women would experience such exclusion if liberal and participatory models of citizenship were synthesized, creating what she calls a 'differentiated universalism' (1997:39). This would allow for positive discrimination and different levels of participation and give more weight to social and economic rights. Lister contends that feminist endeavours in that direction would require three things. First, shifting the borders of the public-private divide so that women's needs became recognized as 'political'. Second, questioning hegemonic notions of the common good, and third, building women's individual and collective confidence in political participation. At the same time, women need to continue to hold politicians to account (Lister 1997:33-42). Such a formulation, I suggest, offers a useful framework within which to view the citizenship challenge facing Indonesian migrant worker NGOs at the time of the 2009 ban.

With this framework in mind, I set out in this chapter to examine the evolution of citizenship practices in Indonesia in response to repeated (and

3 Formulated at the United Nations Fourth World Conference on Women held in Beijing in September 1995 . 
verified) reports of migrant domestic workers being abused. ${ }^{4}$ Grounded in a case study of the three-year dispute with Malaysia as portrayed in the Jakarta Post, Indonesia's largest English language newspaper, the chapter explores two questions. First, taking up one of the key themes of this volume, what can we learn about the ways in which civil society activists, in this instance the press and migrant worker NGOS, operating in a weakly institutionalized state, can succeed to some degree in holding a government to account? Second, is there any evidence of a shift in dynamics, a change in the representation of the migrant worker, and a greater sense of citizenship entitlement and participation amongst the women themselves?

To answer these questions, I will first outline the policy framework and gender norms underpinning the Indonesia/Malaysia trade in domestic workers. Next I summarize the relationship between migrant worker NGOs and the government prior to the 2009 ban. Then I examine the interplay between activists, the press, newspaper readers and government as revealed in the Jakarta Post coverage of the dispute with Malaysia, charting changes in government policy and in the representation of migrant domestic workers. Finally, I draw on interviews I held with journalists in Jakarta in the summer of 2012 to reflect on the possibilities for further realization of domestic worker citizenship rights. Lister's ideas about the public-private divide, the common good and political participation will weave through the discussion to come.

My reliance on the Jakarta Post perhaps needs some explanation. I undertook this study as part of an MA dissertation and with limited time and not yet fluent Indonesian, I decided to focus on English language sources. The Jakarta Post stood out because of its reputation for reliability, its online archive and wide circulation. Chaired by respected international relations scholar and former politician, Jusuf Wanadi, (csis, n.d.), the Jakarta Post belongs to the Kompas- Gramedia Group (Haryanto 2011:106-108) whose flagship publication Kompas has been recognized internationally as perhaps the most trustworthy Indonesian newspaper, at least as far as economic and political reporting goes (Varshney, Panggabean and Tadjoeddin 2004:9). The Group also has a strong media rather than industrial portfolio so is potentially less invested in the migration 'industry' than the other English language daily, the Jakarta Globe, where Haryanto found that some journalists believed its owner was more concerned about his business interests than 'objective information'

4 For a comprehensive account of the evidence of abuse in the system see Help Wanted:Abuses against Female Migrant Domestic Workers in Indonesia and Malaysia. Human Rights Watch, July 2004 Vol. 16, No. 9 (B). 
(Haryanto 2011:108-110). Given the close links some Jakarta Post staff have with prestigious US and UK institutions (CSIS, n.d.), its coverage may tend to reflect dominant international migration management paradigms. On the other hand, it aims to 'promote an Indonesian perspective amidst the deluge of Western viewpoints dominating the global view of information', albeit perhaps a Jakarta oriented one.

\section{Migrant Domestic Workers before 2009}

Prior to the 2009 ban up to 4000 women a month left Indonesia to become domestic workers in Malaysia ('Govt Ban may Lead to Increase' 2009), earning at least five times more than they might have done at home (Rudnyckyj 2004:416). Malaysia's rapid economic growth created high demand while Indonesia's market niche lay in having a ready supply of cheap and docile labour, undercutting the Philippines (Chin 1998:179-182). Costs were kept down by imposing low wages, long hours, no days off, mandatory live-in arrangements, restrictions on women's right to marry, bear children or enjoy family reunification, and an immigration status which tied women to a particular job making it impossible for them to bargain once arrived. Women who left their employment early risked arrest and deportation and Malaysian labour legislation excluded 'informal' work in the home (Varia 2010:8-13). Such arrangements rendered domestic workers vulnerable to psychological, physical and sexual abuse (Ford 2006b:321).

Nevertheless, Indonesian government policy up to 2009 was to promote the export of domestic workers (Kaur 2010:8; Silvey 2004:251). To some extent this was a continuation of established practices. Successive colonial and postcolonial governments had long sponsored out-migration from overcrowded Java to relieve unemployment and reduce the risk of social unrest (Tirtosudarmo 1999:217). Government thinking also reflected World Bank policy (Ratha and Shaw 2007:133-134). Recognizing the potential of remittances, in the 1990s the government began licensing private companies to recruit and export workers and created a Bureau of Labour Export within the, ${ }^{5}$ and set ambitious targets to send more (female) workers overseas (Tirtosudarmo 1999:210-213). By 2009 the value of remittances had reached 6.6 billion us dollar with domestic workers, who accounted for seventy-seven percent of Indonesia's migrant work force, making the largest contribution (IOM 2010:1). As a mark of their commitment to the 'common good' migrant domestic workers were accorded the accolade 'heroines of foreign exchange' (Nurbaiti 2008).

5 From this point in the chapter onwards, 'Ministry of Manpower'. 
Recent studies have documented the intertwined roles of government and business elites in sustaining the supply chain. Lindquist's meticulous exposé of recruitment in Lombok demonstrates that the system depends on traditional patron - client networks reaching down to village level. The business is lucrative: fees to local labour agencies in Lombok almost doubled between 2007 and 2009, rising to six hundred us dollar per domestic worker 'delivered' to Jakarta (Lindquist 2010:124-127) and, as one of my journalist informants in Jakarta commented, 'if you have money you can be a working agent, it's good business, but corruption goes on in the agencies...so many hanky panky' (interview, June 27 2102). Civil servants, village heads and doctors supply passports, birth, medical and training certificates and letters of permission from the applicant's husband or father as household head (Rudnyckyj 2004:407). Other studies focus on state-sponsored training and holding centres designed to 'prepare' women going overseas which in practice often severely restrict their movements and impose highly gendered norms on their dress, speech and behaviour, encouraging unquestioning compliance (Lyons 2005:5-6; Killias 2010:898-899).

To avoid such indignities as well as the high cost and delays of official procedures, many women travelled to Malaysia through unofficial channels (Hugo 2005:65). However, in 2002 Malaysia instituted a policy of mass deportations, deploying RELA, a state-sponsored volunteer organization, to round up undocumented migrants for cash, making 'illegal' migration much more risky (Lindquist 2010:120).

Female labour migration was underpinned by New Order cultural constructions of the virtuous female citizen in which humility, deference to male leaders and family members, and notions of gratitude were more significant than individual rights. Women's responsibilities to the nation lay in fulfilling their kodrat (their female 'destiny') as wives and mothers; their duty was to maintain family harmony and raise virtuous citizens for the future. Both Kathryn Robinson (2009:84-86) and Kate O'Shaughnessy $(2009: 32-35,199)$ have analysed New Order legislation, particularly the 1974 Marriage Law which enshrined men as heads of families, and the Civil Servants' Marriage Regulations (PP 45/1990 and PP10/1983), and drawn the conclusion that by downgrading women's citizenship the political elite bolstered their own hegemonic masculinity. At the same time, O'Shaughnessy suggests, official endorsement of the subordination of women within families offered a degree of compensation to non-elite men for their virtual exclusion from the political realm (2009:199). To this end, gender-neutral ideals of citizenship were supplanted by the notion that women's citizenship was defined by her difference and was embodied in the role of obedient wife and mother (Robinson 2009:72; O'Shaughnessy 2009:198).

As more women entered the paid workforce, women's citizenship was redefined again in the early 1990s (Robinson 2009:91). Women in paid employment 
had to fulfil a dual role, always putting their family first and always ensuring they met their marital obligations to manage arrangements on the domestic front, at the same time contributing to Indonesia's economic development (Blackburn 2004:25-26,182-184; Suryakusuma 1996:99). As Carla Jones expressed it in her portrayal of Javanese middle-class home life in the 199os, 'the image of the sparkling clean, emotionally harmonious domestic space had been harnessed...to appear as the exclusive focus of women whose work in the home was performed out of feminine love and caring' (2004:514).

Such a framing of the domestic realm rendered paid domestic workers invisible (Elias 2010:854). Since women were only secondary earners, working class women who took up domestic work were easily constructed as victims of 'neglectful or absent husbands' or of adverse economic conditions rather than as willing participants in the labour force (Blackwood 2008:18). Working in someone else's home, women became putative, albeit junior and subservient, members of their employers' families expected to show gratitude for the privilege of entering a modern and affluent household (Jones 2004:523).

Susan Blackburn suggests in her comprehensive study Women and the State in Modern Indonesia that women's membership of the polity was strongly communitarian. In the interests of the 'common good' women were offered an unequal citizenship, predicated on and reinforced by a patriarchal demarcation of the public-private divide at national and community levels (2004:104-109). Crucially for Indonesian women, their citizenship is multi-layered but central governments have proved both unwilling and largely unable to challenge women's frequent subordination within their families, religious or ethnic groups (Blackburn 2004:87-88). Consequently, the women's movement has consistently campaigned to bring private matters into the public and therefore political domain and to persuade the state to intervene to help transform those aspects of their local communities, which they perceive as restricting their freedoms (Robinson 2009:164; Blackburn 2004:88). It would seem, then, that in seeking reforms, migrant worker NGOs were challenging not only the commodification of female labour inherent in the international migration industry but also the gender regimes inside Indonesia which served to maintain it.

\section{Rights-Based Counter-Claims: Migrant Worker and NGo Activism Prior to 2009}

Kathryn Robinson (2009) and Sylvia Yazid (2008) have provided detailed accounts based on interviews with former activists of how NGOs became involved with migrant domestic worker issues. They suggest that the pattern of 
Indonesian NGO and government relationships was set in the 1990s. Solidaritas Perempuan (with the strap line Women's Solidarity for Human Rights) was the first organization to advocate on behalf of domestic workers, campaigning against proposals to prohibit the trade, saying: 'They want to stop, we want to regulate as the women have the right to work and that must be defended' (Robinson 2009:108). Its options were, however, limited. One former chair recounted an attempt to meet the minister for Women's Rights when they 'were not admitted into the building...[we] could only shout on the terrace while making noises by banging pots' (Yazid 2008:7). Several other studies argue that Indonesian governments lacked the political will to protect migrant worker rights, leaving responsibility with the labour companies (Silvey 2004:252; Hugo 2005:59; Tirtosudarmo 2011:13). Without access to policymaking, Solidaritas Perempuan and the other NGOs which followed it, looked to the press and international human rights organizations to legitimize their claims that the government was culpable in not protecting Indonesian women's rights. ${ }^{6}$

Given the government's lack of engagement, returned women migrants and NGOs used the political and press freedoms following Suharto's resignation to make even more 'noise'. They demonstrated in front of a recruitment office in Jakarta in October 1998, occupied the office of the minister for Women's Affairs on May 1st, 1999 and organized mass protests to secure the repatriation of an Indonesian domestic worker sentenced to death in the United Arab Emirates in April 2000 (Robinson 2009:115-116). In 2002, Malaysia deported some 400,000 Indonesian migrants to a small town in East Kalimantan, creating a humanitarian crisis. A consortium of NGOs used their citizen's right to file an action against President Megawati and eight other government officials, accusing them of failing to meet their human rights' responsibilities under Indonesian law. This step proved decisive; following the crisis various departments committed themselves to more interventionist policies (Ford 2006a: 228-247).

Over the next two years the Ministry of Manpower created a complex regulatory structure, the Ministry of Foreign Affairs improved services to domestic workers overseas and the Ministry for Women's Empowerment focussed on protection rather than prohibition. In 2004 the Indonesian parliament passed Law Number 39/2004 on the Placement and Protection of Migrant Workers, and ministers agreed a new MOU with Malaysia (Robinson 2009:116). Migrant domestic workers however, were not covered in this memorandum. Although Malaysia took the significant step of agreeing that their 1955 Employment Act would apply to Indonesian migrant workers in general, their legislation

6 Michele Ford (2006) estimates that by 2006 over one hundred NGOs were dealing with migrant labour. 
specifically excluded domestic workers from all the inherent safeguards except for recourse against irregular or late payment of wages (HRW 2004:74). This sort of exclusion not only reflects an underlying belief that rights- claiming should not extend to the domestic domain but also speaks to the low status and invisibility of paid domestic work in both Indonesia and Malaysia (Elias 2012:22; Robinson 2009:102; Anggraeni 2006:199-200).

Although Malaysia and Indonesia signed a separate bilateral agreement covering domestic workers in 2006, NG Os and international agencies remained highly critical (Rahayaan 2006). Women would in future have written employment contracts but employers could still retain women's passports, there were no limits on working hours, no minimum wage, no provision for a day off and women were still prohibited from getting married (Varia 2010:13). Hence NGOs intensified campaigns to persuade Indonesia to ratify the United Nations Convention on the Rights of All Migrant Workers and Their Families ${ }^{7}$ which differentiates migrant rights on the basis of 'legality' and 'illegality' but not on the basis of gender or the formal or informal nature of their work (Komnas Perempuan 2009).

In sum then, relations between migrant worker NGOS and the government by 2009 were predominantly adversarial with NGOs adopting a strategy of bringing into public view the sometimes shameful consequences of the commodification of female labour. The government had shown itself to be more reactive than proactive in developing migration policy, but over time government and NGOs had developed a common agenda in the sense that both saw the extension of the state's regulatory powers as one way to curb abuse.

\section{Mobilizing Support for Migrant Domestic Workers in the Jakarta Post}

Recent studies of the media in post-Suharto Indonesia suggest that journalists have the potential to mobilize and mediate citizenship practices. Journalists take pride in their investigative journalism and see themselves as watchdogs and missionaries, supporting disadvantaged groups, condemning malpractice and improving society (Steele 2011:99; Romano 2003:56-57; Sen 2008:2-4). Kitley argues that the press not only provides a platform for separate interest groups to promote their own views but also serves to create a sense of shared citizenship by engaging wider publics (2008:210-212). Wichelen (2010) examined recent, heated, public contestations about the female body conducted

7 From here on referred to as the 'United Nations Migrant Worker Convention'. 
through the media including debates about pornography, public piety, female leadership and polygamy. Seeing these contestations as citizenship practices, she suggests that when women noisily demanded political visibility, challenged gender stereotypes and sought to re-work definitions of the virtuous citizen and the common good, many different publics became engaged (2010:114-115). Sensational stories such as that of Siti Hajar sell newspapers; these studies raise the question of how far journalists built on public interest to promote reform.

The Jakarta Post and Kompas journalists I met with gave the impression that the issue of migrant domestic workers resonates in a similar way across Indonesian society. Their editors give 'top headlines' to stories about migrant workers and the newspaper has had one journalist covering the topic full-time. I located some $45^{\circ}$ articles in the Jakarta Post archive published between January 2009 and June 2012 which dealt with domestic workers in Malaysia. There were never fewer than five, frequently more than ten, and sometimes more than 20 articles each month over the three years. My analysis concentrates on three periods: May/June 2009, December 2010 and May/June 2012. These were the periods of peak reporting which corresponded with moments of intense pressure on the government or turning points in negotiations with Malaysia.

The overall tenor of the reporting appears to be that of a morality tale. Women are not the main protagonists but the subject of two intertwined contestations. On the one hand, NGOS and international agencies are frequently set against the two nation-states of Indonesia and Malaysia who need to be goaded into taking action to protect migrant women. On the other hand, since the Indonesian and Malaysian governments are continually in conflict with each other, the migrant domestic worker becomes a matter of nationalist pride. Thus she comes to symbolize a struggle between women (and indeed, citizens) and the state, and at the same time becomes emblematic of that state. ${ }^{8}$ Beneath the surface of the narrative, I suggest, is an ethical one about the kind of nation Indonesia wants to be.

\section{Migrant as Victim: May/June 2009}

The predominant trope in the forty-five articles published in May and June 2009 was that of migrant domestic worker as heroic victim, somewhat akin to

8 For a fuller discussion of the way female citizens, particularly in postcolonial states, carry the burden of symbolizing a nation's 'identity and honour', see Nira Yuval-Davis (1997) Gender \& Nation, London: Sage Publications. 
the returning soldier. The stories of five women run through the two-month period: Siti Hajar, with whom I began this chapter, Kartini, who died as a result of her injuries Nurul Wijayanti, found dead at her employer's home, and Modesta Rangga and Sumasri, both hospitalized following abuse (Suherdjoko and Maryono 2009). Descriptions of the women's wounds, scarred faces and bruised 'bodies and thighs' emphasize violation and hint at sexual abuse ('Another Indonesian maid' 2009). However, the women are portrayed as emblems of the nation; hence it is the nation, which is shamed rather than the women or their families. A senior embassy official, for example, accompanied Kartini's body home while a village head in East Java was reported as awaiting the return of Nurul Wijayanti's body. Kartini and Siti Hajar are linked with iconic 'suffering' female figures: the wife of the Prophet Ibrahim who suffered piteously because of her husband's response to her infertility and Indonesia's national heroine who died in childbirth ('Another Indonesian maid' 2009; Rusdi 2009). 'Home' for the injured victims, following their rescue by (male) government officials was thus in the confines of the village and under the protection of their families.

Thirteen articles include comments from rights-based NGOs including Migrant Care, founded in 2004 to campaign for male and female migrant workers, three legal aid organizations and the International Labour Organization (ILO). Articles focus on women's experiences in Malaysia and echo themes of victimhood, vulnerability and disempowerment, often showing the domestic worker as lacking agency, uneducated and unskilled and therefore, perhaps, responsible for her abuse. NGOs castigated Indonesian embassy staff for ineptitude in handling cases, demanded revision of the 2006 MOU with Malaysia and pressed for ratification of the United Nations Migrant Worker Convention. Migrant Care and The Legal Aid Institute were particularly outspoken accusing the 'incumbent president and vice president' of being interested only in their re-election, capitalizing on the fact that the Siti Hajar case coincided with the 2009 Presidential election campaign ('Concrete measures needed' 2009).

Even so, the pattern of government reluctance to act decisively observed in the pre-2009 period appears to be repeated, at least initially. The government made no moves towards reform following Kartini's death in May, indeed, immediately following her death the head of the Migrant Workers Placement and Protection Agency issued a press release celebrating the 11.64 billion us dollar remittances received the previous year and announced plans to make migration easier ('Migrant workers sent' 2009). The consulate secretary in Malaysia deflected attention away from Kartini's death focusing instead on other problems migrants caused the embassy (Suderdjoko and Maryano 2009). Only after the publicity surrounding Siti Hajar did ministers move cautiously towards a 
moratorium while expressing fears of unemployment and loss of foreign currency. Delays were justified as arising from a need for departmental coordination ('RI may stop' 2009).

Readers expressed a range of views. A frequent response was to blame Malaysians and especially Malaysian Chinese. Readers express feelings of hurt national pride and anger that Indonesia was reduced to sending its workers overseas, particularly to 'uncivilized' Malaysia which has 'stolen' Indonesian culture. Some readers believe the press over-dramatizes issues, but more want Indonesia to emulate the Philippines in taking a tougher line on protecting its citizens. On December 11th for example, one reader, Dodo, argued that 'it is the job of the government to ensure that its citizens are protected, even when those citizens are overseas. This is something the government needs to improve so that it can fulfil that basic obligation towards its citizens.' ('Comment: Empowering our migrant workers' 2009). The trope of the uneducated domestic worker, prevalent in 2009, recurs, often with the rider that Indonesian education needs improvement. A minority of readers mention the lack of protection for domestic workers at home and a few advocate a total ban.

In June, government spokespersons shifted their stance, implementing the moratorium and indicating that they would take NGO agendas into negotiations with Malaysia. NGOS on their part seem to have achieved these concessions by reinforcing stereotypes of the migrant domestic worker as vulnerable, uneducated and having little agency. As Rachel Silvey pointed out in her study of domestic workers going to Saudi Arabia, NG Os mobilize the state's own 'paternalistic discourses' and images of 'idealized femininity' (2004:258). While victim narratives clearly engage the public and shame the government they do not serve so well to undermine the sorts of private/public divides in which gendered unequal citizenship is embedded.

\section{Shifting the Ground? December 2010}

Four events in December 2010 brought gendered power relationships rather than victimization into public view. First, Malaysia deported thousands of migrants drawing attention to the Indonesian government's failure to police its own migration policies and creating problems for Indonesia reminiscent of the 2002 mass deportations ('1372 RI Workers Deported' 2010). Second, Malaysia humiliated Indonesia by winning the ASEAN Football Federation Cup, provoking strong anti-Malaysian feelings. Third, ministers from both states attended a bilateral commission meeting in Bali, which would be likely to be conducted in a tense atmosphere of heightened sibling rivalry with Indonesian politicians 
under intense media scrutiny (Weiss 2010:172). Lastly, International Migrants Day and International Human Rights Day were both celebrated during the month. NGO and other non-state actors took advantage of heightened public interest to pressurize the government while various parts of the state apparatus engaged in a 'blame game' (Adamrah and Khalik 2010.). In this context the discourse around migrant domestic workers seems to change. Rather than victims of Malaysia, migrant women become 'subjects' for bureaucratic and technological state regulation, and the focus of articles moves from individual women to that of the nation-state. The underlying question raised was whether the Indonesian government could maintain its legitimacy while it continued to fail to protect the civil rights of its migrant domestic workers, and continued to neglect the social and economic rights of its poorer citizens in general.

Jakarta Post editors appear to have taken a strongly interventionist line in this period. Twenty of the twenty-nine stories published about migrant domestic workers carried criticisms of the government from NGOS, academics, journalists or international agencies. Rather than using the mass deportations to vilify Malaysia, non-state actors accused the government of complicity with malpractice nearer home, drawing attention to Indonesia's failure to protect its own citizens. Seven articles blamed the Ministry of Manpower for poor quality pre-departure training using headlines such as ' $\mathrm{RI}$ domestic helpers expected to work with no tools of trade' and 'PJTKIs criticized for poor training'. Whereas in 2009 domestic workers were described as low skilled, these reports expose labour agency incompetence and government failures in regulation. While most pieces still implicitly blame abuse on women's own shortcomings, one journalist quotes a domestic worker, Indriati, who challenges this, pointing out that even good training will not necessarily deter abusive employers (Sijabat 2010b).

Corruption and ineffective bureaucracy is another repeated theme. The language is frequently outspoken. Indonesia, for example, is 'full of thieves and witches' who prey on migrants (Suryakusuma 2010) and a returned migrant and the director of Migrant Care accused the government of 'legalizing' and 'financing modern slavery' ('Even the Best' 2010). Labour agencies also blamed the government for malpractices. A journalist visited a training centre where he found that 'Migrant worker and labour supply company staffers said labour export mechanisms were the same as before without any significant breakthroughs...they still had to struggle with red tape and pay fees to government officials' (Sijabat 2010b).

Editors also found space in the paper for 'authoritative voices' supporting migrant worker rights. As well as featuring critical reports from Amnesty International and Human Rights Watch, the paper carried a series of seven 
longer-than-average, analytical pieces all of which went beyond 'victim' narratives, written by academics and researchers within and beyond Indonesia. Of these, three represented the struggle to protect migrant domestic workers as part of a broader women's movement against patriarchal, ineffectual and unrepresentative government. The remainder focused on 'technological' solutions, arguing for tighter laws and supervision and urged Indonesia to adopt and implement international norms. NGOs demanded reform of the bureaucracy, decentralization, an Indonesian domestic worker law and ratification of the United Nations Migrant Worker Convention. Overall, non-state actor intervention in the discourse during this period shifted the ascription of weakness and blame from the migrant domestic worker to the Indonesian state.

Sustained public criticism led ministers to defend themselves but in the process, political rivalries came into view. The foreign minister issued a statement highlighting his own department's initiatives and (implicitly) criticizing other ministries (Budianto 2010). Later, still under pressure, he issued a second statement saying that although his ministry is 'often blamed by the public', the Labour Placement Directorate and Ministry of Manpower should be held equally responsible (Adamrah and Khalik 2010). In turn, the minister of Manpower announced two new decrees. One reduced the role of the Placement and Protection Agency to that of 'operator' while retaining key regulatory and supervisory powers within the Manpower Ministry. The second delegated some powers over migration to regional authorities (Sijabat 2010a), perhaps responding to criticisms from some regions that the government lacked real understanding of the issues or determination to deal with problems. The Jakarta Post supported this position, asserting that: 'compared to violence and abuse by employers in the destination countries, problems such as identity fraud, cheat, systematic extortion, detention, et cetera, which occur in Indonesia make up $80 \%$ of the problems' (Bachtiar 2010).

This sense that the government in Jakarta is to blame is echoed in the letters and comments pages. While readers express a range of views, what seems to be shared is the sense that migrant domestic workers embody readers' hopes and fears for their newly democratic nation ('Comments: Empowering our Migrant Workers' 2010). If migrants are victims, they are victims not so much of Malaysia but of an unscrupulous government which tolerates corruption and fails to provide for its citizens at home as this reader's comments following an article by a senior journalist (Sijabat 2010b) expressed it:

It seems like another one of those promises, when the heat is on, ending with no results or solutions. The scavengers (VARIOUS GOVERNMENT DEPARTMENT OFFICIALS) are all out for money from the migrant 
workers before they leave Indonesia and when they return. The migrant workers are copping abuse while they are employed overseas and before they leave by their so-called protectors.... Look in your own backyard.

In sum then, this brief analysis of the December 2010 press coverage suggests that by exposing the 'grubby' details of the Indonesian end of the migrant domestic worker trade and mobilizing diverse publics, NGOs and the press not only held the government to account but advanced their claims that domestic labour and the needs of disadvantaged female citizens are important matters of political concern. One element of success lay in invoking feelings of shame. Not only were Indonesian citizens mortified by the repeated dishonouring of their compatriots overseas and their government's apparent unwillingness or inability to protect them, they expressed feelings of shame and disillusionment about the corruption, deception, fraud and exploitation apparently embedded in the Indonesian end of the migration chain. These feelings were legitimized by international rights-based organizations which claimed migrant domestic workers rights as 'global citizens'. At the same time the migrant domestic worker seems to have been transformed into a powerful symbol of Indonesia's 'little people', excluded from many of the material and social benefits of Indonesia's economic growth and democratization. The challenge is to the state's legitimacy in abandoning its most vulnerable citizens to the deregulation, privatization and marketization inherent in the globalized domestic worker trade.

\section{A New Direction? January 2011 to June 2012}

Widespread and prolonged public criticism of the government seemed to produce a new sense of urgency and acted as a catalyst for policy change. In January 2011 the $\mathrm{DPR}^{9}$ agreed to prioritize a Domestic Worker's Bill, covering home as well as overseas workers. In May, Indonesia and Malaysia agreed upon a new MOU which allowed women to retain their passports, entitled them to a day off a week and safeguarded their right to communicate with families and the embassy. Recruitment fees were capped. While this agreement did not meet all NGO demands, it was an improvement on its 2006 predecessor. The government established a joint task force with Malaysia, commissioned a legal firm in Malaysia to support migrants, and instituted a migrant worker 'hotline'. On 14 June 2011, the government publicly shifted its policies towards a multilateral, rights-based approach to migration when President Yudhoyono endorsed

9 The Indonesian House of Representatives. 
ILO standards for migrant workers in a keynote speech at the hundredth ILO Conference in Geneva. Pressures on the government did not abate, however, particularly because the Saudi Arabian authorities went ahead with the execution of an Indonesian migrant domestic worker named Ruyati Binti Satubi on June 18th, leading to extremely critical and prolonged national and international press coverage blaming ministers for failing to intervene ('President To Meet House' 2011). The DPR summoned the foreign minister to defend Indonesia's record, but questions continued to be asked until the president held a press conference on 23 June announcing that Indonesia would impose a ban, similar to the moratorium with Malaysia, to pressurize Saudi Arabia to agree to new bilateral agreement offering workers more protection (Simamora 2011). In May 2012, the minister of Manpower urged ASEAN states to implement and improve their own agreement on the protection of migrant workers and spoke of 'the fundamental rights and dignity of migrant workers and their family members' (Sijabat 2012, 11 May). Finally, in April 2012 Indonesia ratified the United Nations Convention on the Rights of All Migrant Workers and Their Families, a step activists had been calling for since 1993 .

\section{Agency and Empowerment? May/June 2012}

In May and June 2012, themes of victimhood and weakness, so prevalent in 2009, appear to be being replaced by those of agency and empowerment. Women workers' voices figure much more prominently. 'To show and to empower' introduced Murtini, once 'a helpless...maid' but now 'a brave domestic worker unafraid to stand up for her rights', Ririn, confident in 'demanding' her rights, and Lita, previously a domestic worker but now an actress. Rather than relying on NGOs to speak for them, these women had joined a theatre group which stages performances across Java using stories written by returned workers (Krismantari 2012). A woman named Baby Nasution was deported from Malaysia when a compulsory medical showed she was HIV positive. Her story, presented as triumph over adversity, not tragedy, tells how Baby built a new life, married, had children, and helped establish the first national HIV network for women. In Baby's words: 'there are many [HIV Positive] women out there who are abused and...get infected through lack of information, unaware of their legal protections. These issues motivate me in my work' (Emilia 2012).

Other reports similarly challenge the 'vulnerable victim' and 'heroine of the nation' paradigms. A hospitalized worker is seen not as victim but as a heroine to be praised for 'fighting strongly with three armed men' who were trying to kidnap her employer's child; here it is not her earning power or ability to 
send back remittances but her moral and physical courage which is singled out for praise ('Indonesian Maid in Malaysia' 2012). A report from Hong Kong depicts migrant domestic workers such as Sriyatin, who had plans to open a new style duck eggs business, avidly taking advantage of business workshops to learn entrepreneurial skills ready for when they return (Christanto 2012). Such stories frame migrant domestic workers as powerful individuals who not only improve their own and other workers' lives but participate as active and articulate citizens as well.

Domestic work, too, is now more frequently framed as a responsible job to be viewed alongside other categories of employment rather than the refuge of the lowest skilled. At a regional meeting of national and international agencies held in Kuala Lumpur, several NGos (Migrant Care, Solidaritas Perempuan, CARAM Asia and Tenaganita) called for the moratorium not to be lifted until domestic workers had the same legal protections as other workers (Sijabat 2012, May 10). Here, I suggest, the women are calling upon not just their rights as Indonesian citizens but as members of a transnational community of global citizens claiming and negotiating 'universal' rights.

Migrant domestic workers are also linked as real 'workers' with trade unions. On the first of May, the Indonesian Labour Union Confederation urged the president to be 'firm' with Malaysia about migrant workers, including domestic workers, (Priyambodo 2012) while JALA PRT, an organization representing home and overseas domestic workers, 'urged' the DPR to pass the 'long-awaited' Domestic Worker Bill (Krismantari 2012). A member of the DPR, Rieke Pitaloka, demanded 'a special job description for housemaids'. If accepted this would differentiate work as a 'maid' from that of cook, gardener or babysitter, hopefully reducing the domestic worker's load (Govt Told to Keep' 2012). This sort of framing of the migrant domestic worker replaces a collective of heroic women going overseas on behalf of the nation with the notion of women as individuals with 'inherent' human rights, including the right to 'decent work' and the freedom to travel in search of it. An art exhibition held at Taman Ismail Marzuki, Suharto's showpiece cultural centre also stressed the importance of seeing migrant domestic workers as individuals. The catalogue explained that, 'the term migrant worker does not apply to a certain social group. Migrant workers are individuals who are part of families living in certain areas' (Indrasafitri 2012).

Women whom the New Order had constructed as export targets but otherwise neglected, were gaining entry into the nation's political and cultural space. However, deeply held beliefs about women's 'nature' and fears of their sexuality still seem to be in conflict with women's rights as independent workers and the idea that abused women are to blame re-enters the discourse. This is seen, 
for example, in a comment which accuses migrant women of undermining village values by placing 'material goods' over family harmony (Krismantari 2012). The head of the government's migration task force, a former minister of Religion and ambassador to Saudi Arabia, felt able to state baldly his opinion that abuse results from 'flirtatious behaviour'. He went on to say: 'it always takes two to tango. Maybe they are driven by their desires but the migrant worker's attitudes are surprising' (Pramudatamo 2012). NGOs and trade unions united in condemning his views, but such stories perhaps hint at the emergence of a counter-discourse with strong religious undertones.

The minister for Manpower also caused consternation by announcing on May 29th that the government planned to stop sending migrant domestic workers abroad altogether by 2017. Anis Hidayah from Migrant Care responded angrily, accusing the president of merely mouthing 'empty words' when he told the ILO he recognized domestic worker as being in the formal sector (Christianto and Pramudatama 2012). This apparently contradictory announcement reveals, perhaps, the impact of conflicting pressures on the Indonesian government. Increasingly well-coordinated NGOs, international agencies and other authoritative voices demanded they be tough with Malaysia and take seriously the task of implementing regulatory frameworks and international norms. On the other hand, perhaps less clearly articulated, deeply embedded beliefs in women's kodrat (innate nature), ambivalence towards modernization and development agendas and some interpretations of Islam led others to see permanent prohibition as a better solution. However it does seem clear that the combination of press and NGO advocacy had not only held the government to account but also tapped into readers' concerns about the 'common good'. As one reader put it, 'What kind of nation does democratic Indonesia want to be?' (Guharoy 2012).

\section{By Way of Conclusion: Future Reflections}

The discussions I had with two journalists from the Jakarta Post and three from Kompas led me to reflect on the persistent challenges as well as new possibilities suggested by this case study of citizenship practices. All my respondents recognized that turning government rhetoric about migrant domestic workers into reforms on the ground will be slow. They expressed some cynicism, saying that although ministers react 'when the press makes a lot of noise' and politicians use migrant issues in campaigning, this 'doesn't mean they care'. Implementing new regulations is problematic where corruption is endemic. As one 
journalist put it, 'after fourteen years we have learnt that every political party is corrupt once is has gained power'. Even the minister for Manpower, who 'used to be so poor he couldn't afford shoes', faces corruption charges (interview, 27 June 2012). The telling of this story epitomizes perhaps the emblematic position of the migrant domestic worker as the embodiment of the 'left-behind' poor, and especially of the left-behind poor women who not only are not benefitting from Indonesia's substantial economic growth but find themselves having to go overseas in the search for better futures (De Silva and Sumarto 2014:239-240). In the meantime, as was frequently re-iterated to me by activists pushing for the domestic worker bill, some wealthy politicians and public officials are said to have five or more domestic workers in their own homes and DPR members appear generally reluctant to support claims for a minimum wage for domestic workers (interview, 30 July 2015; observation JALA conference 16 June 2015). Nor is decentralization felt to be a remedy since, as I was told by another journalist, it can 'make little kings in the regions [who] don't help the smaller people' (interview, 28 June 2012).

Secondly, some Islamic groups continue to push for permanent prohibition. The head of the PKK (Family Welfare Movement) in Bandung was quoted in August 2012 as saying, 'I ask...how can they meet the basic need of the biological, nobody could answer. I therefore agree that the MUI [Muslim Council of Indonesia] issued a fatwa that do not allow women to become migrant workers' (Yulianti 2012). Hizbut Tahrir Indonesia held a well-attended and wellresourced international women's conference in Jakarta in January 2013 arguing for the state to 'eradicate' migrant domestic work and ensure women are financially supported by male relatives or the state (Muslimahediacentre 2013). However, while well-publicized, such views may be in a minority. Of greater significance may be the work of Fatayat NU, the women's branch of the Muslim mass organization Nahdlatul Ulama. Fatayat NU is a strong advocate of the rights of migrant domestic workers, aiming to empower women by providing 'the theological arguments for the rights of migrant domestic workers as workers, as citizens and as Muslims' (Rofiah and Nadjib 2010). While one of the journalists I interviewed felt that Indonesian women need to be vigilant about the extension of syariah, not least because the Ministry for Women's Empowerment has limited influence, the Kompas journalists I met, by contrast, downplayed religion as a possible restraint on women going overseas, arguing that economic imperatives are of greater significance in determining their choices.

Thirdly, although my case study provides evidence of a change in the status of migrant domestic workers in terms of media framing and entry into public space, there was little evidence of any change in relation to the gendered division of labour and gender hierarchies within families. My informants suggested 
that attitudes to gender and migration could be different outside the capital, depending on local norms and economic circumstances. While continuing debate about migrant workers has provided opportunities for women to demonstrate political leadership and for returned migrants to build confidence in political participation, publicly performing shifts in gender relations and resistance to the normative gender regime, my interviewees felt that the gender order in Indonesia is proving slow to change. One Kompas journalist spoke honestly of his own family saying, 'For me, I have to work and earn money...my wife has to stay in the house and take care of my kids' (interview, 27 June 2012).

Finally, and returning to Ruth Lister's ideas about how to move towards a more female-friendly, differentiated conception of citizenship, press and NGO participation in the public debate about migrant domestic workers going to Malaysia does seem to have made domestic workers, inside Indonesia as well as overseas, much more visible. Ati Nurbaiti, the feminist journalist at the $J a-$ karta Post, shared with me her view that the issue of domestic workers has been seen as 'outside the democracy sector', hidden within the 'private' realm. As she said: 'We do not discuss maids in Indonesia'. She explained that Jakarta Post journalists are aiming to persuade their readers to 'see the link' between the treatment of domestic workers overseas and the way Indonesians treat their own domestic workers at home. She believes an Indonesian law on domestic workers is vital, 'but I think it's not time yet...it is only supported by women's groups and although the percentage of women in the DPR is at its highest yet at 18\%, I don't think it' s enough' (interview, June 27 2012).

On the other hand, NGOs and the press caused some embarrassment to the Indonesian government by bringing out the 'dirty linen' of the Indonesian end of the migrant domestic worker trade. By linking the needs of working class, disadvantaged women with more middle class anti-government and anticorruption agendas, press and NGOs mobilized a wider public. In so doing, they not only pushed the government to change its policies but contributed to a broader change in the status and public perception of the migrant domestic worker, and potentially, of the Indonesian domestic worker at home. The question as to why domestic workers inside Indonesia received much less attention than domestic workers overseas would seem to merit further investigation. Just as in Malaysia, Indonesian domestic workers, at the time of writing, are excluded from national labour legislation. Although their cause might not engender the strong feelings of (masculine) national pride that fuels public outrage about migrant domestic workers, they could equally well come to symbolize Indonesia's neglected underclass. Nor does their location within the private realm necessarily exclude them from discussions of citizenship entitlement; activists have, after all, succeeded in getting legislation passed to 
ban domestic violence (Law No.23/2004). However, specific legal protection for domestic workers constructs them as workers rather than subordinate family members and hence challenges the legally enshrined position of men as household heads. At the same time, as in Malaysia, middle class women in Indonesia depend heavily on domestic workers to fulfil the gender expectations placed on them (Elmhirst 1999:258). Open discussion of domestic worker pay and work conditions could therefore invoke contradictory feelings of selfinterest and shame, feelings which a family metaphor of domestic workers serves to cloak and contain. ${ }^{10}$

\section{References}

1372 RI workers deported in November. (2010, December 4).Jakarta Post.

Adamrah, M. \& Khalik, A. (2010, December 30). Poor coordination risks diplomacy. Jakarta Post.

Anggraeni, D. (2006). Dreamseekers: Indonesian women as domestic workers in Asia. Jakarta: Equinox.

Another Indonesian maid allegedly abused in Malaysia (2009, June 28), Jakarta Post.

Bachtiar, P. (2010, December 23). Local govts key to emigration governance. Jakarta Post.

Blackburn, S. (2004). Women and the state in modern Indonesia. Cambridge: Cambridge University Press.

Blackwood, E. (2008). Not your average housewife: Minangkabau women rice formers in West Sumatra. In M. Ford \& L. Parker (Eds.), Women and work in Indonesia (pp.17-40). London: Routledge.

Budianto, L. (2010, December 1). Government faces challenges in protecting migrants. Jakarta Post.

Centre for Strategic and International Studies (CSIS). (n.d.). CSIS Foundation:Jusuf Wanandi. Retrieved on February 2, 2016, from http://www.csis.or.id/foundation/page/ jusuf_wanandi.html.

Chin, C. (1998). In service and servitude: Foreign female domestic workers and the Malaysian 'Modernity' project. New York: Columbia University Press.

Christanto, D.( 2012, May 20). Migrant workers ponder their future. Jakarta Post.

Christianto, D. and Pramudatamo, R. (2012, June 29). Govt vows to stop sending maids abroad by 2017. Jakarta Post.

Comment: Empowering our migrant workers. (2010, December 11).Jakarta Post.

10 See the discussion in Locher-Scholten (1998). 
Concrete measures needed to end labor abuses", (2009, June 19). Jakarta Post.

De Silva, I. \& Sumarto, S. (2014). Does economic growth really benefit the poor? Income distribution dynamics and pro-poor growth in Indonesia. Bulletin of Indonesian Economic Studies, 5o(2), 227-242.

Elias, J. (2010). Making migrant domestic work visible: The rights-based approach to migration and the 'challenges of social reproduction'. Review of International Political Economy, $17(5), 840-859$.

Elias, J. (2012). Foreign policy and the domestic worker: the Malaysia-Indonesia domestic worker dispute. International Feminist Journal of Politics, 15(3), 391-410.

Elmhirst, R. (1999). Learning the ways of the priyayi: Domestic servants and the mediation of modernity in Jakarta, Indonesia. In J. Momsen (Ed.), Gender, migration and domestic service (pp.242-265). London: Routledge.

Emilia, S. (2012, May 27). The moment of truth.Jakarta Post.

Even the best have problems too: Activist. (2010a, December 21). Jakarta Post.

Ford, M. (2006a). After Nunukan: The regulation of Indonesian migration to Malaysia. In A. Kaur \& I. Metcalfe (Eds.), Mobility, labour migration and border controls in Asia (pp. 228-247). Basingstoke: Palgrave Macmillan.

Ford, M. (2006b). Migrant worker organizing in Indonesia. Asian and Pacific Migration Journal 15(3), 313-333.

Govt ban may lead to increase in illegal migration to Malaysia. (2009a, June 28). Jakarta Post.

Govt told to keep its policy on workers. (2012a, June 7).Jakarta Post.

Guharoy, D. (2012, May 1). Analysis: What kind of nation do Indonesians want?. Jakarta Post.

Haryanato, I. (2011). Media ownership and its implications for journalists and journalism in Indonesia. In K. Sen \& D. Hill, Haryanto, I. In Politics and the media in twentyfirst century Indonesia: Decade of democracy (pp. 104-18). London: Routledge.

Hugo, G. (2005). Indonesian international domestic workers: Contemporary developments and issues. In S. Huang, B. Yeoh \& N. Rahm (Eds.), Asian women as transnational domestic workers (pp.54-91). Singapore: Marshall Cavendish.

Human Rights Watch (HRW). (2004). Malaysia: Labor accord fails Indonesian Migrant Workers. Retrieved from https://www.hrw.org/news/2004/05/10/malaysia-labor-ac cord-fails-indonesian-migrant-workers.

Indrasafritri, D. (2012, May 15). Showing the struggles of migrant workers. Jakarta Post. I.O.M. (2010). International migration and migrant workers' remittances in Indonesia. Makati City, Philippines: International Organization for Migration.

Jakarta Post (n.d,). Company Profile - Online edition. Retrieved on February 2, 2016 from http://www.thejakartapost.com/company_profile.

Jones, C. (2004). Whose Stress? Emotion work in middle class Javanese homes, Ethnos, $69(4), 509-528$. 
Kaur, A. (2010). Labour migration in Southeast Asia: Migration policies, labour exploitation and regulation. Journal of the Asia Pacific Economy, 15 (1), 6-19.

Killias, O. (2010). 'Illegal' migration as resistance: Legality, morality and coercion in Indonesian domestic worker migration to Malaysia. Asian Journal of Social Science, 38, 897-914.

Kitley, P. (2008). Out there: Citizens, audiences and mediatizaton, in K. Sen \& T. Lee (Eds.), Political Regimes and the Media in Asia (pp.208-226). Abingdon, Oxford: Routledge.

Komnas Perempuan. (2009). Dari Siti Hajar to perlindungan pekerja migran. Retrieved on October 10, 2012 from http://www.komnasperempuan.or.id/2009/o6/dari-siti -hajar-ke-perlindungan-pekerja-migran-tuntutan-ratifikasi-konvensi-migran-199o -dan-seruan-penguatan-kerjasama/.

Krismantari, K. (2012, June 6). To show and to empower. Jakarta Post.

Lindquist, J. (2010). Labour recruitment, circuits of capital and gendered mobility: Reconceptualizing the Indonesian migration industry. Pacific Affairs 83(1), $115^{-132 .}$

Lister, R. (1997). Citizenship: Towards a feminist synthesis. Feminist Review 57, 28-48.

Locher-Scholten, E., (1998) 'So Close and Yet so Far: The Ambivalence of Dutch Colonial Rhetoric on Javanese Servants in Indonesia 1900-1942', in Clancy-Smith, J. and Gouda, F. (eds.) Race, gender and family life in French and Dutch colonialism. Charlottesville,Va.; London: University Press of Virginia, pp. 131-153.

Lyons, L. (2005). Embodying transnationalism: The making of the Indonesian maid. In E. Lorek-Jezinska and K. Wieckowska, (Eds.), Corporeal inscriptions: representations of the Body in Cultural and Literary Texts and Practices (pp. 171-185). Torun,Poland: Nicholas Copernicus University Press.

Maryono, A. and Suherdjoko (2009, May 29). Migrant worker's body flown home. Jakarta Post.

Maulia, E. (2009, July 7). Malaysia, RI to revise agreement on workers. Jakarta Post.

Migrant workers sent Rp 120 home last year. (2009c, May 27).Jakarta Post.

Mohanty, C. ( 2003). Feminism Without Borders. Durham \& London: Duke University Press.

MuslimahMedia centre. (2013, December 10). News report of Hizbut Tahrir International Women's Conference Indonesia. Retrieved on October 15, 2014 from http://www .youtube.com/watch?v=Hg8lwaCIzEI.

Nurbaiti, A. (2008, July 20). 'No sense of urgency' to help Indonesia's heroes. Jakarta Post.

O'Shaughnessy, K. (2009). Gender, state and social power in contemporary Indonesia: divorce and marriage law. London: Routledge.

Piper, N. (2003). Bridging gender, migration and governance: Theoretical possibilities in the Asian context, Asian and Pacific Migration Journal, 12(1), pp. 221-248. 
Pramudatamo, R. (2012, May 30). 'Flirtatious' migrant workers to blame for abuse: Govt task force. Jakarta Post.

President to meet House, Cabinet to discuss migrant worker protection. (2011, June 23). Jakarta Post.

Priyambodo, R. (2012). Labour unions urge President Yodhoyoni to be firm against Malaysia. Antara News. Retrieved from http://www.antaranews.com/.

Rahayaan, S. (2006). Solidaritas Perempuan's statement on MOU between Indonesia and Malaysia. Retrieved on September 9, 2013 from http://www.zoominfo.com/Cached Page/?archive_id=o\&page_id=16o8745476\&page_url=//www.mfasia.org $/ \mathrm{mfaState}$ ments/Statement52-SPonMOU.html\&page_last_updated=2010-02-24T10:55:48\&firs tName=Salma\&lastName=Rahayaan.

Ratha, D. \& Shaw, W. (2007). South-South migration and remittances, Washington D.C. : The World Bank.

RI may stop sending workers to Malaysia. (2009, June 23). Jakarta Post.

RI, Malaysia hold border talks in Bali. (2010c, December 7).Jakarta Post.

Robinson, K. (2009). Gender, Islam and democracy in Indonesia, Abingdon, Oxon.: Routledge.

Rofiah, N. and Nadjib, A. (2010). Mari kenali hak-hak buruh migran Indonesia: Perspektif Islam dan perempuan. Jakarta: Fatayat NU. Retrieved October 12, 2013 from http:// r4d.dfid.gov.uk/pdf/outputs/womenempmus/fatayat_marikenali_series2.pdf.

Romano, A. (2003). Politics and the Press in Indonesia. Abingdon, Oxford: Routledge.

Rudnyckyj, D. (2004). Technologies of servitude: Governmentality and Indonesian transnational labor migration. Anthropological Quarterly, 77, pp. 407-434.

Rusdi, M. (2009, June 18). Letters: Siti Hajar's suffering. Jakarta Post.

Sen, K. (2008). Mediating political transition in Asia. In K. Sen \& T. Lee, (Eds.), Political Regimes and the Media in Asia. Abingdon, Oxford: Routledge.

Sijabat, R. (2010a, December 9). Govt recovers loopholes in migrant worker transfer. Jakarta Post.

Sijabat, R. (2010b, December 31). Migrant workers still waiting for change. Jakarta Post.

Sijabat, R. (2012, May 11). RI reminds ASEAN of migrant workers' protection deal. Jakarta Post.

Silvey, R. (2004). Transnational domestication: state power and Indonesian migrant women in Saudi Arabia. Political Geography 23, pp. 245-264.

Simamora, A. (2011, June 23). President: Indonesia to ban labor export to Saudi by Aug. 1. Jakarta Post.

Steele, J. (2011) Indonesian journalism post-Suharto: Changing ideals and professional practices. In K. Sen \& D. Hill, (Eds.) Politics and the media in twenty-first century Indonesia: Decade of democracy (pp. 85-103). London: Routledge.

Suherdjoko \& Maryano, A. (2009, May 29). Migrant workers body flown home. Jakarta Post. 
Suryakusuma, J. (1996). The state and sexuality in New Order Indonesia. In L. Sears \& J. Suryakusuma, (Eds.) In Fantasizing the Feminine in Indonesia (pp.92-119). Durham: Duke University.

Suryakusuma, J. (2010, December 20). A tangled tale of Indonesian women. Jakarta Post.

Thomas, L. (2009, July 28). Indonesia Pushes for Better Migrant Worker Protection. TIME World. Retrieved on September 28, 2013 from http://content.time.com/time/ world/article/o,8599,1913134,oo.html.

Tirtosudarmo, R. (1999). The Indonesian state's response to migration. Sojourn:Journal of Social Issues in Southeast Asia 14, 212-228.

Tirtosudarmo, R. (2011) Migrant workers as a constitutional challenge for Indonesia, in Migrant Workers in Asia: Policies and Practices in Social Sciences. Jakarta: UNESCO.

Varia, N. (2010). Slow reform: Protection of migrant domestic workers in Asia and the Middle East. New York: Human Rights Watch.

Varshney, A., Tadjoeddin, M.Z., \& Panggabean, R. (2004). Patterns of Collective Violence in Indonesia, 1990-2003. UNSFIR.

Weiss, M. (2010). Malaysia- Indonesia bilateral relations: Sibling rivals in a fraught family. In N. Ganesan \& R. Amer, (Eds.). International relations in South East Asia: between bilaterism and multilateralism ( $p p$. 171-198). Singapore: Institute of South East Asian Studies.

Wichelen, S. (2010). Religion, politics and gender in Indonesia. Abingdon, Oxon: Routledge.

Yazid, S. (2008). Activism of Indonesian NGOs on the issue of women migrant workers: Engaging in national and international cooperation. Paper presented to 17 th Biennial Conference of the Asian Studies Association of Australia in Melbourne, 1-3July 2008 retrieved on October 12, 2013 from http://artsonline.monash.edu.au/mai/files/2012/ 07/sylviayazid.pdf.

Yulianti, T. (2012). Netty Heryawan Support MUI Fatwa issuing prohibition TKW. Detik Bandung. Retrieved on September 20, 2012 from http://bandung.detik.com/re $\mathrm{ad} / 2012 / 07 / 08 / 121459 / 1960349 / 486 /$ netty-heryawan-dukung-mui-terbitkan-fatwa -pelarangan-tkw. 


\title{
Yellow vs. Red and the Rise of a New Middle Class in Thailand
}

\author{
Apichat Satitniramai ${ }^{1}$
}

During the last two decades, Thailand's political climate had changed profoundly, resulting in an unprecedented divide between two fronts: the socalled Yellow Shirts (People's Alliance for Democracy, or PAD) and the Red Shirts (United Front for Democracy against Dictatorship, or UDD). Both parties are currently locked in an arduous conflict, with the Yellows initiating a mass mobilization to oppose the Reds who represent the anti-coup forces who have rallied around exiled Prime Minister Thaksin Shinawatra and his alleged 'nominee' governments.

This divide is perhaps the first example of nationwide mass politics in Thai political history. It is no surprise, then, that this phenomenon has provoked both Thai and foreign academics alike to seek explanations for the emergence of these political mass movements. In this chapter I posit that this issue is not so much about clashes between the 'haves' and the 'have-nots', or elite conflicts carried over to the clientelist masses of supporters. I argue, instead, that we are looking at the coming-of-age of a new Thai middle class. This idea is supported by recent research on the socio-economic characteristics of both the Reds and the Yellows.

The Yellows are representative of the 'old' established middle and upper classes, who have been well integrated economically and politically with the elites since the 1970s. The Reds, on the other hand, are identified as the vanguard of an emerging class of lower middle-income, market-oriented earners, the product of Thailand's economic growth during the past two decades. It is this emerging class, and not the poor, that forms the majority of voters in Thailand's electoral system at present. The livelihoods of the members of this class depend crucially on market transactions, both in consumption and production, while the persistence of considerable economic inequality, together with the development of electoral politics at the national and local levels, has

1 I would like to thank the TUHPP for funding this project and thank all eight members of the research team for their comments during discussions and exchanges of ideas, as well as for their suggestions for data from which this article has benefited. Any errors this chapter might contain remain the responsibility of the author alone. 
propelled them to emerge with a sense of citizenship. Critically, they have come to realize that electoral politics is the form of institution that serves their interests best.

In contrast, the 'old' middle and upper classes presently comprise the minority of voters. Although more powerful economically, their political significance is threatened by the growing significance of electoral politics. The electoral victories of the Thai Rak Thai party and its successor parties caused their political influence to diminish, thereby provoking much resentment. And from November 2013 to May 2014, a political group - an alliance between factions of the Yellows and the Democrat Party, calling itself People's Democratic Reform Committee $^{2}$ - occupied central Bangkok. The months-long occupation created a pretext for the coup on 22 May 2014 that brought Thailand under military control. The conflict between the Reds and the Yellows, therefore, might be seen as a clash between the growing political aspirations of and emerging class and resentment among the middle and upper classes over the resulting changes.

As the introductory chapter of this book suggests, a study of citizenship in Southeast Asia might need to develop an analysis of citizenship that is sensitive to class differences as well as possible rural - urban divides' since 'heterogeneous populations claim diverse rights and benefits associated with citizenship. I propose in this chapter that the current political conflict between the Yellow and the Red Shirts may be understood as a class conflict. Not in the traditional meaning of a class struggle between a working class without the means of production and an oppressive capitalist class, or between the rich and the poor - which has been suggested by Ungpakorn (2009), Hewison (2012), Taylor (2012) and Forsyth (2010), but as a conflict between the newly emerging lower middle class (the Red Shirts) and the old middle class (midmiddle class and higher) that comprise the Yellow Shirts.

This article is divided into six sections. The first section tests proposals drawn from empirical data on the identities of the Red Shirts and Yellows Shirts, and discusses their socio-economic characteristics. In the next part, the formation of these two mass movements as social classes is contextualized historically through a discussion of the changing socio-economic conditions in Thailand during the last two decades. The third and fourth sections discuss the respective interests of the two sides, and addresses the question whether their political conflicts can perhaps be seen as a class conflict. The fifth part discusses whether these mass mobilizations and conflicts imply or

2 The Democrat Party is the oldest political party in Thailand but became the main 'permanent' opposition party since the establishment of the Thai Rak Thai government in 2001. 
reflect changing meanings of citizenship, while the final section comprises the conclusion of the study.

\section{Who are the Red and the Yellow Shirts?}

It could be claimed that the literature concerning the current colour-coded conflict in Thailand can be divided into two strands. The first is predominately represented by left-leaning scholars, such as Ungpakorn (2009), Hewison (2012), Taylor (2012) and Forsyth (2010). These authors analyse the conflict mainly as a working-class-based movement against the exploiting class, or a 'class war' (Ungpakorn 2009:76). They describe the supporters of the Red Shirt movement as 'rural and working-class people', and 'people who [experience] disadvantage[s] and exploitation' (Hewison 2012:157), 'the lower and middleincome peasantries of Thailand' (Forsyth 2010:465), 'urban and rural poor' (Ungpakorn 2009:76), or a 'marginalized subaltern peasantry' (Taylor 2012:296). On the other hand, they identify the Yellow Shirt supporters as 'the middle classes and rich elites' (Ungpakorn 2009:76, 82), or 'the minority elites and Bangkok middle class' (Taylor 2012).

In contrast, the liberal-minded authors of literature on the Red versus Yellow conflict, such as Naruemon Thabchumpon and McCargo (2011), Keyes (2010), Walker (2012) and Pattana Kittiarsa (2012), argue that the Red Shirt movement is mainly supported by economically better-off rural-born Thais, and not the poor. For example, Naruemon Thabchumpon and McCargo (2011) characterize the Red Shirts as 'urbanized villagers', while Keyes (2010) and Walker (2012) identify them as 'cosmopolitan villagers' and 'middle-income peasants' respectively.

Although this second group of academics acknowledge that the Red Shirt supporters have a lower socio-economic status than their yellow-clad fellow countrymen, they do not consider this colour-coded conflict as a class war. The Red movement, after all, does not intend to overthrow the state but aims to assert the political rights of its supporters and to obtain state subsidies within the framework of a parliamentary democracy. Although both analyses present a general image of the current Thai political divide, their characterization of the conflict lacks large-scale quantitative evidence.

The first quantitative study which attempted to adequately describe the demographic and socio-economic characteristics of the Reds and Yellows was conducted by Ammar Siamwalla and Somchai Jitsuchon (2012). The study surveyed a nationwide 4,097 households in August and September 2009 and, surprisingly, found that factors such as economic status (rich or poor), region 
(northeast, north, et cetera), and employment status (employer, employee or self-employed) did not indicate the likelihood of being a Red Shirt. Therefore, it seems that the general belief among the Thais that the poor always support the Red Shirt movement is a myth. Their second conclusion reads that 'there is a clear tendency for better-off people to be Yellow'. Thus 'Bangkok people, across all income classes, are more likely to be Yellow, while outside Bangkok the better-off are more likely to be Yellow' (Ammar and Somchai 2012:66).

A survey with a sample size of 2,200 in five provinces, from the project Reexamining the Political Landscape of Thailand (Apichat et al., 2013) and conducted by Wanwiphand in April-June 2012, further confirmed Ammar's and Somchai's (2012) conclusions. Wanwiphand found that, firstly, Red Shirts were more likely to have lower socio-economic status than Yellow Shirts, and were also more likely to work in the agricultural or informal sectors. In contrast, it was found that more Yellow Shirts than Red Shirts were civil servants, state employees, or businesspeople. Secondly, more Yellow Shirts than Red Shirts had completed a higher level of formal education. As for incomes, the income levels of both Yellow and Red Shirts were not statistically different. Thus Yellow Shirts have higher economic and social status than Red Shirts, with a higher level of education and more secure employment in business or as professionals. A Red Shirt generally has a lower level of education, and earns an irregular income as a commercial agriculturalist or (semi-)skilled labourer, or is selfemployed in the informal sector. It should be noted here that the Red Shirts are not always necessarily among the poorest; it turns out that they generally have higher incomes than Thais who are 'apolitical.' 3

Although these two recent studies disagree on a number of issues (such as the employment status of the Yellow and Red Shirts), they both consider the Red Shirts as having a lower socio-economic status than the Yellow Shirts. Based on these findings, I postulate that the majority of the Red Shirts comprise an emerging lower middle class whose members are found in both urban and rural areas. This view opposes the categorization found in the above mentioned literature that describes the Red Shirts as mainly rural poor, workingclass people, or non-poor rural residents. As for the Yellow Shirts, I follow Nithi Eawsriwong $(2008,2010 a)$, who concurs that the Yellow Shirt supporters are members of the established middle class, especially in urban areas. ${ }^{4}$

3 According to our survey, the 'apolitical' group is the smallest group. It composed $5.42 \%$ of the total samples, while the Red Shirts, the Yellow Shirts and the 'Neutrals' composed $46.75 \%$, $28.44 \%$ and $19.39 \%$ of the samples.

4 See Nithi Eawsriwong 'The reformulation of the political system' and 'Who Are the Yellow Shirts and Why Have They Emerged?' 


\section{A New Middle Class: Socio-economic Changes during the Last Two Decades}

The above line of reasoning suggests that the struggle of the Red versus Yellow Shirts can be partly attributed to the political rise of this new, lower middle class. The Thai Rak Thai (TRT) party noticed this group, and designed policies to transform this new social force into the base for their party. The question is how this new middle class gained political prominence? The answer to this question lies in the socio-economic changes during the last two decades.

As of the late 1980s, Thailand has seen a continuous sharp growth of its economy and, as a result, has been 'upgraded' by the World Bank from a lower middle-income to an upper middle-income country. From 1986 to 2009, Thailand's Gross Domestic Product grew considerably and the average income increased to six thousand baht in 2009 (TDRI 2011:47-48). During this period, the average household income increased by as much as $8.8 \%$, while household expenditures grew by $7 \cdot 3 \%$. Household savings and assets accumulated as well. Not surprisingly, the percentage of people living under the poverty line declined dramatically from $42.2 \%$ in 1988 to $7.7 \%$ in 2010, that is just over five million people. Moreover, the incidence of poverty in rural areas decreased from $49.7 \%$ to about $10 \%$, whereas in urban areas it fell from $23.7 \%$ to $2.6 \%$ in the same period (Pasuk and Pornthep 2012:13-14).

In parallel with the increase in average income and the decrease of poverty, the structure of production in Thailand shifted from the agricultural sector to the industrial and service sectors. This change was reflected in shifts in the occupational structure. The number of agricultural households tended to decline by $1 \%$ per year, while unskilled labour decreased as well. Simultaneously, the proportion of three other occupational categories - business owner, professional/technician, and clerical-sales-services - started to grow. The number of people employed in industrial production and crafts rose sharply between 1986 and 2006, but fell slightly between 2006 and 2009 (TDRI 2011:37).

In 2009, 5 those with more than five thousand baht income per capita per month were identified as middle class. This means that, of the above occupational categories, only farmers and those earning an income with unskilled labour have not reached middle-class status $(32 \%$ of total households in 2009, reduced from $55 \%$ in 1986). Among the middle class as a whole, people working in clerical-sales-services and industrial production are categorized as lower middle class. They make up $35 \%$ of total households, and have an average income per month of 5,000-10,000 baht. In this lower middle-class group, the sales-and-services group grew sharply from $10 \%$ of all households

5 In 2009, the poverty line was 1,586 baht per capita per month. 
in 1986 to $20 \%$ in 2009. This section expanded from urban to rural areas and from Bangkok to other regions, and has an average income of 5,828 baht per month. This is similar to the income of industrial production workers, and almost twice as high as that of farmers. However, this level of income is still lower than the average income per capita (6,239 baht) in 2009 (TDRI 2011:38). In conclusion, the lower middle class, excluding farmers, comprises around one-third of households in Thailand.

The extensive changes in the agricultural sector of the last twenty years resulted in the formation of a new, lower middle class. Reviewing the past of the Thai agricultural sector and looking into its future, Ammar Siamwalla (2004:11) concluded that the Thai rural areas will gradually achieve a better status. The general belief, particularly prevalent among the middle class of Bangkok, that rural equals agriculture equals poverty, is likely to become less true. Between 1989 and 1998, more than 3,5 million male and female workers and students, aged 15-34, left agriculture and rural areas for the cities. After having left, these young people did not return to their rural home region to work in agriculture. This caused a severe labour shortage in the agricultural sector. Farmers coped with this shortage by turning to machinery and other, technological, means. Combined, these drastic changes made that farming ceased to be a family activity.

Currently, Thai rural society no longer functions as a traditional peasant society, as it has split into two groups: professional/commercial farmers and traditional/subsistence farmers. Farmers from the first group tend to be younger, make more use of modern production techniques and are more capable of dealing with market fluctuations. Also, their farms are usually larger, as they use machinery and hired labour to overcome family labour shortages. A professional farmer generally earns far more than the average traditional farmer. Professional/commercial farmers will become the largest group of the agricultural sector in the future.

The Food and Agricultural Organisation of the United Nations (FAO 2006: II, 40-41) defines professional farmers as households that obtain more than $60 \%$ of their total income from agriculture and where the head of the household has no secondary job. Its findings show that there were 1.36 million professional farmer households (that is $19 \%$ of farm households) in 2004 compared to 0.94 million in 1986 . While the number of farm households increased by $23 \%$ in that period, so did that of professional farm households, by $45 \%$ that is. The latter's monthly income increased from 2,525 to 9,311 baht, whereas that of traditional farmers during the same period increased only from 941 to 1,366 baht. Moreover, a professional farmer's income is almost $75 \%$ above the average income of a traditional farmers. We can therefore identify this group 
of farmers as a new middle class in the agricultural sector. ${ }^{6}$ The traditional farmers are elderly people, whose children have left home and who rely on their childrens' remittances from outside the agricultural sector. They practice subsistence agriculture and will become increasingly less important for the agricultural sector in the future.

The shift of the agricultural sector away from a traditional farming society is also visible in the diversity of new occupations that sprung up in the rural areas, such as construction work, contracting, hairdressing, beauty therapy, retail sales, selling prepared food and motorcycle and agricultural machinery repair. In the past, these occupations did not exist in these areas due to insufficient demand. Therefore, the proportion of farmers has shrunk not only as a part of the total population, but also as a part of the rural population.

Keyes (2010) portrays the changes that have taken place in the Thai countryside over the past fifty years in his fieldwork in Nong Tuen village, Mueang District, Mahasarakham Province. His findings largely substantiate the view of Ammar Siamwalla. Keyes found that, in 2005, not a single family in this village was growing rice for sale; they grew it for consumption by their extended families. For example, in a family with two sons and two daughters in this village, both sons and one son-in-law drove taxis in Bangkok. The second daughter lived in the village and grew rice to sustain all four families, using a capitalintensive method of farming in all stages of production (Keyes 2010:15-16). The three family members in Bangkok regularly sent money home and occasionally travelled home to provide labour. From this perspective, it is no surprise that these three taxi drivers called themselves 'villagers' or 'farmers', even though nearly all of their income came from the non-agricultural sector. Keyes further shows that migration from the agricultural sector to the cities first only involved men, but that later, women also began leaving their village for the city. This first-hand experience with living and working outside the village, as well as the arrival of education and the penetration of mass media during the last two decades, have all greatly transformed the worldview of these 'villagers', to the point where, these days, the label 'cosmopolitan villagers' seems more fitting for them.

From the above discussion of Ammar Siamwalla and Keyes, we may infer that Thai rural society is no longer a static traditional farmer or peasant society. Although Thai living in rural regions and villagers mainly living in the

6 From the figure of $19 \%$, we can roughly estimate that this forms $5 \%$ of the total number of households in the country since agricultural households make up at least $25 \%$ of all households. Thus in 2009, the lower middle class households - both within and outside agriculture - constituted $40 \%$ of Thai households. 
cities still consider themselves as 'villagers' and 'farmers', their economic way of life is fully market-oriented, whether they worked in the agricultural sector or not. These 'farmers' enjoy higher incomes than they did in the past, but their main source lies outside the agricultural sector. Summarizing these findings, it can be said that Thai socio-economics have changed greatly, and that these changes entailed the formation of a new middle class, whose members are found both within and outside the agricultural sector and rural regions. At the same time, the poor have become a societal minority. Now that it has been explained how it mainly is the Red Shirts who enjoy this new, middleclass socio-economic status, it is time to address their common interests and concerns.

Despite an overall improvement in the standard of living in Thailand, the income disparity between the poor and the rich remains large. Inequality over the past two decades, as measured by the Gini coefficient using household income, has improved only slightly, while the coefficient measured by household income has worsened. In contrast to many ASEAN neighbours which

Gini

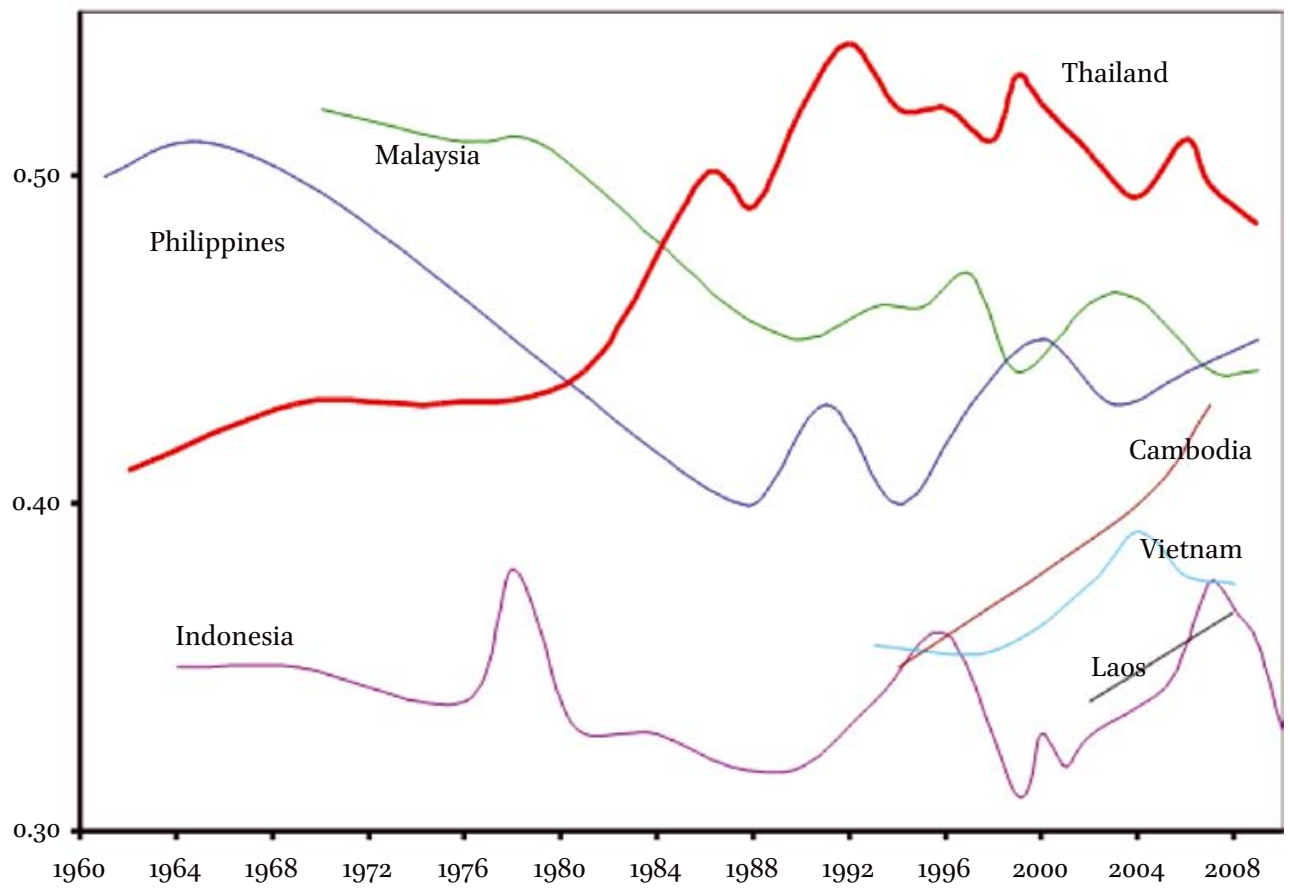

FIGURE 12.1 Gini coefficients of household income, selected Southeast Asian Countries SOURCE: PASUK AND PORNTHEP (2013:11). 
have declining income inequalities, Thailand's Gini coefficient has tended to increase over the past fifty years of economic development.

Household income inequality in Thailand, measured by the share of total consumption expenditure, is expressed in Figure 12.2. The share of the top $20 \%$ of the population with the highest expenditure slowly declined from $50.05 \%$ in 1996 to $46.68 \%$ in 2010 . In contrast, the share of expenditure of the bottom $20 \%$ with the lowest consumption increased slightly from $6.10 \%$ in 1996 to $6.76 \%$ in 2010 (Pasuk and Pornthep 2012:15-6). This economic inequality is even more pronounced when we consider the asset inequality: the top $20 \%$ has sixty-nine times more assets than the bottom 20\% (Pasuk and Baker 2012:219).

Turning to wage inequality, the poorest $10 \%$ of workers earned just $1.85 \%$ of the total wage income in 2006 , with an average wage income of 1,468 baht $(38.7$ us dollar) per person per month. This share increased slightly in 2010 to $2.22 \%$ with an average income at 2,133 baht (67.2 Us dollar). The top earners' share of total wages also increased from $35.11 \%$ to $36.96 \%$ between 2006 and 2011 . The ratio between the wage share of the highest and the lowest declined from 18.97 in 2006 to 16.66 in 2010 (Pasuk and Pornthep 2012:16-17). Meanwhile, the share of wages in the factor incomes, which is a rough measurement of income distribution between capital and non-capital owners, hovers at around 0.5-0.6, making Thailand's wage share relatively low when compared with developed economies (0.65-0.7 in EU and US). Moreover, between 2002 and 2009, the real Gross Domestic Product grew at around $5 \%$ per year, while real wages of workers only grew at the yearly rate of $1.4 \%$. And labour productivity rose at an average annual rate of $3.6 \%$ between the fourth quarter of 2002 and the first

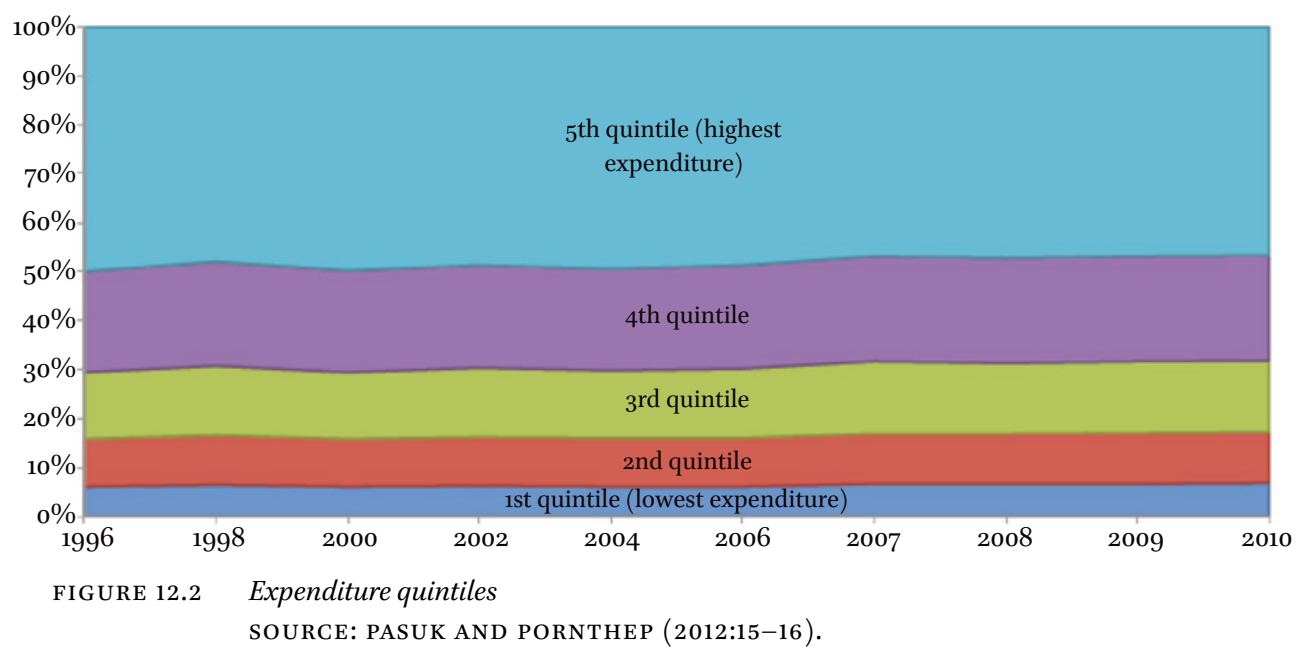


quarter of 2008. This means that the gains from productivity growth have not been accruing to labour wages, but to the employer instead (Pasuk and Pornthep 2012:19, 21).

Apart from healthcare, ${ }^{7}$ coverage of employment benefits and other social welfare benefits, such as old-age pensions, has been limited. In 2014, only $25.1 \%$ of the total labour force were covered by the social security system, which also provides maternity benefits, child allowances, unemployment benefits and an old-age pension scheme. Another $12.7 \%$ are public employees and state enterprise workers who have different pension schemes. Approximately two-thirds of the labour force (about 24 million workers or $62-64 \%$ of the population in the period 2005-2010) were not covered by any old-age pension scheme as they worked in the informal sector (Pasuk and Pornthep 2012:18).

The above discussion makes clear that the 'lower middle class' or the 'new middle class' is a product of socio-economic changes in Thailand, especially during the past twenty years. This class is present in both urban and rural areas and its members are found both inside and outside the agricultural sector. Based on the data presented in footnote six above, it is estimated that in 2009, this new middle class constituted around $40 \%$ of the total households in Thailand. Although members of this group are not among Thailand's poorest, they are less well-off than the average middle class and upper class members in terms of both income and assets. Also, many who belong to this new middle class lack social security as they work in the non-formal sector.

The way of life of this group in both production and consumption is closely tied to the Thai capitalist system; many are petty traders and self-employed workers, such as taxi drivers, motorcycle taxi riders, motorcycle mechanics and hairdressers. And, if they are farmers, they are market-oriented professional/ commercial farmers, not traditional/subsistence farmers.

Similar to the old middle class, these people expect to do well and raise their social and economic status under the modern market system. The main difference is that their general capabilities - such as level of education, skills and/or access to capital and economic and social opportunities - are lower than those of the old middle class, thus creating a 'new' middle class with lower economic status than its predecessors. Because their employment is often outside the formal sector, they have no social security protection and, as their employment is closely tied to the market system, their income is uncertain and vulnerable

7 At present, the universal healthcare programme covers $75.2 \%$ of the population. Before the programme started in 2001, this population had no state-provided health insurance. 
to economic fluctuations. At the same time, they are faced with an immense inequality of income, assets and life-opportunities, as the education and other public services they have access to are of inferior quality. In order to rectify these inequalities, the members of this new middle class need social security and support from the state to help them raise their economic status to something close to that of the old middle class.

When the first Thaksin government pushed forward and implemented their campaign promises in the 2001 election, Prime Minister Thaksin Shinawatra and the Thai Rak Thai party became very popular and were greatly admired by the new middle class. This support continued to the present day. The main reasons for this general appreciation were their social programme policies such as universal healthcare, debt rehabilitation and village funds - as these responded to and coincided with the economic demands of the new middle class. These policies, labelled degradingly as 'populist' by some, were intended to improve the lives of the new middle class in various ways. The health insurance programme provided extra security, while other programmes focused on increasing economic opportunities, such as the 'village fund' for cheap loans, or a programme called 'OTOP' which opened up new opportunities for incomegenerating activities.

Thaksin's first government was the first elected government in Thai political history that used these national-level policies to attract enough votes to win an election and then successfully implemented them. Red Shirts who admire Prime Minister Thaksin are likely to say that his policies are concrete, tangible and 'edible' since they make a concrete difference in their daily lives. The universal healthcare scheme, for example, has for some decided on matters of life and death. As it was the lower middle class that directly benefitted from these new policies, they led to an increase in the popularity of Prime Minister Thaksin and the Thai Rak Thai government among members of this class, and increased support for the Red Shirt movement.

I claim that the emergence of this new middle class formed the basis for the formation of the Red Shirt movement. This does not mean, however, that all members or even the majority of this new class are Red Shirts. Neither does it say that members of other economic classes - rich or poor - cannot join the Red Shirts, or, for that matter, that members of the new middle class cannot become a Yellow Shirt, or remain neutral. An individual may or may not choose a political identity, and that person's economic status is not necessarily a deciding factor in specifying their identity. However, given the above survey data, I do argue that a significant number of Red Shirts are people from this new middle class. 


\section{From Subjects to Citizenship: Political Changes and New Citizenship}

The emergence of the new middle class described above is the material basis that facilitated the creation of a new social force of actors in Thai political society. This chapter suggests that political changes over the last ten years have created a new form of political consciousness in members of this group that led to the birth of the Red Shirts. They no longer perceive themselves as commoners, servants or subjects without rights or a voice in the running of their country. Instead, they see themselves as citizens or partners in Thai political society, with an inherent right to co-design their country's fate.

The problems these people were facing in their daily lives were fundamentally political problems, not economic hardship or lack of state support in itself (Nithi 2010b). ${ }^{8}$ What they needed was to develop a political space to further their own interests. As a Red Shirt furniture maker in Chiang Mai Province stated: '[in the past] I relied little on state policy. I planted crops in rotation, melons after rice. I did not think about state policy. I thought that I had to help myself. I had land before, but not enough to sustain me and my family. We have to depend more on state policy and I felt elections were more important for me. 9

Cherishing the right to vote is an inseparable part of the concept of citizenship among the Red Shirts. They define elections as the minimum requirement for a country to be considered a democracy; every individual equally has one vote to appoint or remove their government. ${ }^{10}$ One Red Shirt, defining democracy, said: 'It must come directly from the people. As long as we have to wait for permission [from the authorities], it is not democracy. There must be the right to choose our leaders. If they are no good, we will decide. Our people must not be ousted by a coup.'11 Thus, a coup by the ruling class as an instrument for annulling elections or interfering with election results is, according to the Red

$8 \quad$ Nithi Eawsriwong 'Political Space that Cannot be Closed Off'.

9 Interview with a group in a village in Doi Saket District, Chiang Mai Province, January 2011.

10 Certainly, there is a great diversity of political ideologies among the Red Shirts, but I wish to define the main common denominator in the thinking of the Red Shirts. That is that they believe that elections, in the sense that every person has an equal right to appoint and remove the administration, are a necessary condition of a democracy. Although opinions may vary on whether the right to vote is the only condition of a democratic system, a democracy without elections or with elections that are controlled, in one way or another, by the elite, is not deemed a democracy.

11 Interview with a group in Thonburi, Bangkok, 2010. 
Shirts, a form of politics that lacks legitimacy, as it denies them their share of politics and closes down their political space. Voting is their basic mechanism for pushing and negotiating their interests. The question is how this particular concept of citizenship came about? I believe that we have to look at past political developments for the roots of Thai citizen consciousness.

The foundations of electoral politics at the national level were set in the 1980 s under a semi-democratic system. Although it was an electoral system controlled by the ruling elite, national level elections of Members of Parliament took place regularly, and this led people to believe that the normal role of citizens in politics was to elect the politicians that form the government. So a coup d'état, or other overt political intervention, was considered un-democratic.

In elections before 2001, voters did not directly benefit from policies at the national level, since the content of those national policies was dominated by high ranking bureaucrats and technocrats. Elected politicians had a minimal role. Concrete national policies hardly played a role in electoral campaigns, while the idea of implementing these policies after the election was even less important. The reason for this is that before 2001, national policies favoured local projects, mostly development projects, for which MPs could acquire central budgets, to the benefit of their own constituencies. Or private funds were distributed in cash to individuals during election campaigns.

Thus the 2001 election was the first time ever that a Thai political party - the Thai Rak Thai - operated more or less like a 'programme-based' party, contrasting with an old-style 'clientelistic' parties. ${ }^{12}$ It is no surprise, therefore, that when coups did interrupt the electoral cycle before 2001, such as in 1991, mass opposition movements did not arise as there were no national benefits from the elections to protect.

The key turning point was when the 1997 Constitution came into force. This constitution regulated two issues in particular that turned out successful in their implementation. First, it aimed to facilitate the creation of a strong executive branch to make the Thai state work more effectively. Second, the constitution mandated an unprecedented level of decentralization that transferred a certain degree of power and authority to local governments. Furthermore, Constitution encouraged the formation of big political parties and party policy platforms by changing from multiple-seat constituencies to single-seat constituencies and introducing a party list system, and increased the bargaining

12 See the distinction between clientelistic and programmatic political parties in Kitschelt (2000). 
power of the prime minister and party leader over the cabinet and leaders of political factions.

For instance, the election law required MP candidates to be party members for at least ninety days, and regulated that elections are to be held no longer than sixty days after the House of Parliament is dissolved. Other rules were designed to facilitate a more practical and stable governance by incentivizing politicians to build bigger parties. This would turn, it was believed, the previously fragmented party system into a consolidated two-party system (Hicken 2006). In other words, the 1997 Constitution was designed to give the government more power to devise, reform and implement policies in order to effectively tackle the problems it is faced with.

The Thai Rak Thai party, under the leadership of Thaksin, won the first election under this constitution in 2001, and fully benefited from these new rules. The result was that, for the first time in Thai political history, a government won an election by campaigning on the basis of proposals for national-level policies, and successfully implemented these policies shortly after the election. The popularity of Prime Minister Thaksin and the Thai Rak Thai party increased dramatically. And, more importantly, they won a landslide victory in the following election that enabled them to successfully form a single-party government for the first time in Thai history. The success of the Thaksin government, in which the 1997 constitution played an important role, made voters realize that their votes were 'edible' in the form of national policies.

The constitution also brought about decentralization, forcing the central government to transfer power and budgets to local administrative organizations (LAOS) to an unprecedented degree. At present, it cannot yet be said that the level of decentralization allows LAOs enough freedom for local people to be able to govern themselves independently from the central state - as was the idea behind the decentralization, since control by the central government is still relatively high. However, since 2003, the 7,775 municipal and sub-district administrative organizations and seventy-five Provincial Administrative Organizations (PAOs) throughout the country have, for the first time, had their administrative and legislative bodies elected directly from the local people.

Even though the mechanism of direct elections alone will not ensure complete accountability of LAOs to the people, a survey by the King Prajadhipok Institute (2010) found that there was an increase in the confidence of the people in the work of LAOs from $63.5 \% 2002$ to $71.8 \%$ in 2005. A comparison between the level of confidence in the work of the central government and cabinet, and that in local administrative organizations, shows that the confidence increased from 2007 onward. Satisfaction with the services of local administrative organizations rose from more than $80 \%$ in 2005 to $89.7 \%$ in 2010. 
From this perspective, it can be stated that the large-scale decentralization resulting in the formation of LAOs through direct elections have made local elections more important and meaningful in the daily lives of people in each locality. There are several reasons for this.

Firstly, the duties and resources of LAOs have greatly expanded since 1999. The total current revenue of LAOs nationwide is about $25 \%$ of the central government revenue, and the duties and responsibilities of LAOs have had a direct and clear effect on the livelihoods of voters. Secondly, it is relatively easier for people to make the candidates account to them, especially at the sub-district and municipal level. This is because these localities tend to be small, and the physical and social relationship between candidates and voters is more intimate. It should, therefore, come as no surprise that elections at this level have become much more competitive.

Furthermore, interviews show that villagers in rural areas base their choice for candidate LAO members on the candidate's potential capability to attract development projects and other resources from the central government for the benefit of their own community (Apichat et al., 2010). This is because approximately $40 \%$ of LAO budgets still directly derive from central government subsidies. Moreover, the criteria for allocating budget subsidies of many different kinds to LAOs in each locality empower the central power holders to use broad discretion. This forces LAOs to lobby the central government to obtain higher allocations (Apichat 2011:29-35). This shows that villagers use local elections as a tool to bargain for resources from central government.

In summary, both national and local elections are of more significance to the lives of voters than ever, especially since the proclamation of the 1997 constitution. Political awareness, especially in valuing the right to vote, has increased greatly over the past decade or so.

Against this background, the reactions to the 2006 coup d'état formed a tectonic shift. This coup was different from the previous ones as it was the first coup that yielded a nation-wide mass counter-movement. Resistance to the earlier coups in October 1976 and February 1991 had been limited and concentrated in the old middle class in the urban areas. The new middle class had not yet emerged, and the majority of the population did not yet conceive of themselves as citizens. The 2006 coup brought about a political awareness that the overthrow of the elected Thaksin government was the expropriation of the citizens' right to vote, the latter being the new middle class' most effective political bargaining tool.

The coup lighted the fuse on a political bombshell and paved the way for the formation of the Red Shirt political movement. The Red Shirt movement is an alliance of very loose, mass-based organizations and groups of politicians of 
the former Thai Rak Thai party, led by Thaksin Shinawatra. All one needs to do to identify oneself as a Red Shirt is to join political activities organized by local or national- level Red Shirt groups.

Attempts by some Red Shirt groups to establish a formal membership structure failed, but the movement has been strengthened and consolidated in other ways. In particular, the Reds gained momentum around 2010, after the dissolution of the People Power Party (the reincarnation of the Thai Rak Thai party - which had been disbanded earlier by the judiciary). These developments had been set off by the Yellow Shirts' counter-movement against the elected Samak Sundaravej government and Somchai Wongsawat government in 2008. The massive rally staged by the Red Shirts in Bangkok to call for the dissolution of parliament in 2010, forms yet another illustration of how the Red Shirts movement aims to protect the electoral rights of the new middle class.

\section{What is the Old Middle Class Fighting for?}

Thirty percent of the Thai households derive their income - ranging from almost 15,000 to 20,000 baht in 2009 - from professionals, business owners and industrial workers (TDRI 2011:37-38). This is the middle class, I argue, that provides mass support for the Yellow Shirt mass movement. One can even say that the Yellow Shirts movement forms the frontline of this 'old' middle class. Members of this old middle class are well-off and enjoy high levels of economic security. Thus they have fewer economic demands to negotiate with the state in comparison with the new middle class. The former was the first group to grow up during the economic development of the 1960 s and benefitted directly from the economic growth. From this time on, they have had access to major services provided by the state, including better quality higher education, medical services and social security as well as other forms of infrastructure such as roads, water and electricity, et cetera. Crucially, this class does not have to rely on elections as it has many effective forums and mechanisms at its disposal for negotiating their interests with the Thai state. For example, all branches of the mainstream media are the representatives and mouthpieces of this class, to the point where no past government has been able to survive without taking criticism from the mass media into account.

Another reason why the old middle class, numerically smaller than the new middle class, has bargaining power with the state is its importance in the country's economic structure. Elections are important in bargaining with the state, but for the old middle class, they are not the main political tool. Due to this class' minority status in the country and their urban residence, the establishment of electoral politics at both the national and local levels, especially from 2001 
onward, greatly diminished this group's political influence on the government. Conservative political parties which have long been popular with this class, like the Democrat Party, have not won recent national elections. As the electoral system of the 1997 constitution turned Thai politics into a competition between two big parties, the old middle class' representatives became a single, 'permanent' opposition block. This situation differs significantly from the pre2001 era, when Thai governments were always coalitions, frequently involving the Democrat Party. Over the past ten years, national electoral politics has reduced the political influence of the old middle class.

Similarly, the expansion of local electoral politics, especially after 2003, brought very little benefit to the old middle class. This is because members of this class generally live municipal areas or large cities like Bangkok, where its residents had been granted the right to elect their local government already before 2003. The new middle class - found mostly in rural areas - on the other hand, could elect their administrators only in 2003, under the Tambon Administrative Organizations regulation.

The expansion and establishment of elections at both the national and local levels has not provided extra benefits for the established middle class, while it reduced their political influence. It is therefore no surprise that the ideological strategy of the Yellow Shirts, apart from monarchism, is to diminish, deemphasize and even destroy electoral politics. The slogan '4-second-democracy', used by the Yellow Shirts, describes the 'immorality' of the electoral system as the core problem of the Thai political system. This is because, the Yellows claim, capitalist politicians can become parliamentary dictators and monopolize political power by buying MPs and votes of rural people who are considered as being undereducated, ignorant and poor. ${ }^{13}$ Instead, they propagate a 'New Politics', with $70 \%$ of MPs being appointed and $30 \%$ elected. This would yield, they believe, a new kind of politician, with ethics and morality, to govern the country.

Summarizing, the Yellow Shirt mass movement attempts to preserve their political influence by limiting the impact of electoral politics. They mock electoral politics by comparing it to a soap opera: meaningless, amoral, and not stimulating to the mind. According to the Yellow Shirts, electoral politics is the vehicle of dirty politicians and their henchmen.

13 See, for example, a Yellow Shirt protester from southern Thailand who took part in the protest against the Yingluck's Government in December 2013, who said that, 'We know what is right and wrong, ...but the poor don't know anything. They elect the people who give them money' http://www.nytimes.com/2013/12/04/world/asia/thailand-protests -reflect-searing-divisions-of-changing-country.html?pagewanted=2\&_r=1 last accessed on 16 January 2014. 


\section{Citizenship and the State: From Clients to the New Thai Citizens}

The introductory chapter of this book discusses how 'patronage democracies' 'are succeeding in winning elections by using...their "money power" to buy voters'. And while 'efforts to woo voters by presenting some sort of policy platform is kept to a minimum...the activities of political parties are mostly geared towards facilitating clientelistic exchanges between politicians and voters, rather than facilitating public debate or developing programmatic policy agendas'. The analysis in this chapter suggests that the socio-economic and political development of Thailand over the last two decades has reduced the effectiveness of clientelism as a method of electoral mobilization.

Firstly, as noted above, the main result of the 1997 Constitution was state strengthening and the facilitation of a more effective government by way of programmatic political parties. The constitution encouraged the formation of party policy platforms by introducing a party list electoral system which designates the whole country as a single constituency with a proportional voting rule. This system incentivized political parties to design a national level policy platform in order to maximize votes and, at the same time, discouraged specific, particular, regional or locally focused policies or 'club goods'. Since the first general election held under these new rules in 2001, political parties have responded enthusiastically, with their policy manifestos becoming increasingly important for winning an election.

It can even be claimed that the new electoral system is extremely successful in generating national level policy platforms, especially in terms of redistributing the state's resources to the new middle class at the expense of the old middle class. This is because the new middle class comprises the majority of the voters, while the old middle class represents a minority. And, as expected, this redistribution leads to political conflicts between the two classes. Since Thaksin's party policy platform did promise material improvements to the voters and since the state's resources were redistributed to the voters after the election, one might argue that Thaksin and his party mobilized votes through clientelism.

However, this argument misses the point. Focusing on clientelism as a method of electoral mobilization, Stokes $(2009)^{14}$ points out that it is the distributive criterion of electoral support that distinguishes clientelism from other materially oriented political strategies, namely the programmatic redistributive politics. She defines clientelism as 'the proffering of material goods

14 Strokes, S.C. (2009) 'Political Clientelism' The Oxford Handbook of Comparative Politics http://www.oxfordhandbooks.com/search?siteToSearch=aup\&q=Political+Clientelism+ \&searchBtn=Search\&isQuickSearch=true. Last accessed on 3 March 2014. 
in return for electoral support, where the criterion of distribution that the patron uses is simply: did you (will you) support me?,'15 while the criterion for benefitting from redistributive programmes is: do you occupy a given class of beneficiaries (such as the unemployed, or the retired)? Programmatic benefits, therefore, redistribute resources from classes of non-beneficiaries to classes of beneficiaries. But within a class of beneficiaries, particular people who qualify cannot be excluded.

By contrast, clientelist redistribution always involves exchange. The benefit is only available on the condition that the client complies with the request to provide political support. As pointed out above, the social policies of Thaksin's government, especially universal healthcare, debt rehabilitation and village funds, are the main sources of his popular support. All of those policies' criterions for beneficiaries are non-discriminating, and therefore it cannot be argued that the rise of Thaksin was completely due to a narrow interpretation of clientelism as a method of electoral mobilization.

Consequentially, the practice of vote-buying, although still widespread, is no longer the decisive factor in winning general elections. As argued by Pasuk Phongpaichit (2013), a respected political economist, the pattern of election results has changed. In the past, vote-buying became manifest in election results of adjacent constituencies, showing different parties as winners by highly varying margins. However, in the last decade, this pattern has disappeared. Presently, because mass sentiment is driving the result, constituency after constituency across whole regions are choosing the same party, and by huge margins. This new pattern first appeared in the south in the 1980s, especially after Chuan - the former prime minister - became the Democrat Party leader. The southerners decided that the party was 'their' party, and voting Democrat became part of their regional identity.

Since then, the same pattern has emerged in the northeast and upper north. At the 2011 poll, in constituency after constituency in the northeast and upper north, Pheu Thai - the successor of the Thai Rak Thai party - won 50-60\% of the vote, while the second-place candidate won only $10-20 \%$. If vote-buying is determining the election results, then the question remains: why would the parties buy far more votes than they need to win? Moreover, the survey of the project Re-examining the Political Landscape of Thailand (Apichat et al., 2013) also found that $60-70 \%$ of the correspondents stated that the money they received from politicians had no effect on their decision to choose candidates, both at the national and local election.

15 Emphasis in the original. 
To sum up, political changes, especially the 1997 constitution, have incentivized politicians to change their parties from clientelistic parties into programmatic ones; only by adopting this strategy would they have a chance to win. As a result, voters were able to choose between competing party policy platforms of parties. While a large number of voters still accepted vote-buying money, policies turned out the decisive factor in their electoral choice. We might therefore conclude that it is no longer appropriate to consider the combination of vote-buying and clientelism as a method of electoral mobilization, as the winning strategy of electoral politics in Thailand.

\section{Conclusion}

In this chapter, I have proposed to understand the current political conflict between the Red and Yellow Shirts as a class conflict: not in the traditional meaning of a class struggle between the working class without the means of production and an oppressive capitalist class, or between the rich and the poor, but as a conflict between the newly emerging lower middle class (the Red Shirts) and the old middle class (mid-middle class and higher), known as the Yellow Shirts.

The Red Shirts are the representatives of a new middle class which emerges in both urban and rural spaces, both within and outside the agricultural sector, and in both the formal and informal sector. These people became the new lower middle class as their income rose above the poverty line. This chapter has shown how the conception of Red Shirts as non-poor rural Thais - 'urbanized villagers' (Naruemon Thabchumpon and McCargo 2011) or the 'middle income peasants' (Walker 2012) - does not hold, as a significant number of Red Shirt supporters can be found in non-farm sectors and urban areas. Currently, this new class forms the majority of the population in Thailand.

Even though economic growth in the past two decades has lifted these people out of poverty, inequality of income and assets between this new and the old middle class has remains consistently high. Red Shirts continue to lack social and economic security. Political developments, especially the establishment of electoral politics over the past ten or more years, have created their political consciousness and notion of citizenship. This means that they began to see themselves as stakeholders in society with the right to participate in crafting their own future. However, despite being the majority in Thai society, they still have limited political space and bargaining tools. Elections is their only effective political tool to negotiate state policies that benefit the new middle class citizens. In this sense the emergence of the Red Shirt movement is not 
directly related to economic inequality. The disparity of wealth and income between classes in Thailand has been consistently high since the late 1970s (see Figure 12.1 above). The Red Shirts' emphasis on a 'right to have rights' was mainly a response to political changes, such as the enactment of the 1997 Constitution which made their right to vote meaningful for the first time ever. In this regard, the disparity of wealth may be viewed as a secondary factor that reminds the Red Shirts of the injustices they have suffered, and are still suffering to a certain degree, and that propels them to exercise their rights in order to rectify them.

The 2006 coup d'état and the political developments that followed temporarily negated their citizenship and destroyed their only political tool. It made the Red Shirts realize that they have a 'right to have rights', especially the right to vote and to be counted as equal a citizen as the Yellow Shirts. From this perspective, the aim of the political struggle of the Red Shirts is to guard electoral politics, which is the political institution that protect their interests best.

In contrast, the establishment and expansion of electoral politics at both the national and local levels has reduced the political influence of the old middle class. Elections have never been important or meaningful in the daily lives of this group. Not only are they, in quantitative terms, a minority in Thai society, they also have other political mechanisms and spaces that, in their hands, are more effective than elections for negotiating with, and pressuring governments to promote the policies they benefit from. The mass media is one of these 'spaces' that the Yellow Shirts deploy to further their cause. As a faithful mouthpiece of the old middle class, the media propagates a Thai politics that protects the political influence of the old middle class at the cost of democratic electoral politics.

The political conflict between the Red and Yellow Shirts is about distributive politics. The Reds are staunch protectors of the democratic elections since it is their weapon to pressure the government to allocate resources for their benefit, while the Yellows are threatened by these same elections as they reduce their political role and influence. In these terms, this chapter argues against the perception that this clash is an elite conflict, with both movements as mere political pawns of the elite (as suggested by Crispin 2012). It proposes, instead, to understand the conflict as a class struggle.

The political divide is stemming from the fact that the Yellow Shirts are attempting to deny the Red Shirts political equality as citizens. Socio-economic and political changes have lifted them out of poverty and their old clientelistic exchanges with politicians, and they now realize that they have a 'right to have rights'. And they are ready to fight for that right. Thus, it can be said that the Red Shirts have become 'new Thai citizens'. In this light, I agree with the 
conclusion by Wolfram Schaffar (Chapter 10 in this volume) that 'any concept of citizenship in postcolonial countries that operates with the dichotomy of a rights-conscious, urban middle class versus clientelistic rural poor runs into difficulties with regard to the dynamics of citizenship in Thailand'. I propose to use the term 'new Thai citizen' for the Red Shirt supporters in order to emphasize that they are 'newcomers' who are fighting for effective rights to participate meaningfully in the polity, especially via their voting rights. The Red Shirts are not fighting for the legal recognition of their right to vote as universal suffrage has been granted since the revolution in $193^{2}$ - but for their right to participate in a meaningful way in the democratic politics of their nation.

\section{References}

Ammar Siamwalla (2004). 'The Old Age of the Agricultural Sector: the Past and Future of Thai Rural Areas.' Paper presented at the 2004 TDRI Year-end conference, Pattaya, 27-28 November, 2004 (in Thai).

Ammar Siamwalla and Somchai Jitsuchon (2012). The Socio-Economic Bases of the Red/Yellow Divide: A Statistical Analysis. In M.J. Montesano, Pavin Chachavalpongpun, \& Aekapal Chongvilaivan (Eds.), Bangkok May 2010: Perspectives on a Divided Thailand (pp. 64-71). Singapore: ISEAS Publishing.

Apichat Satitniramai (2011). 'Constitution, Decentralization and Popular Participation.' Paper presented at the Annual Conference of the Faculty of Economics, Thammasat University, Bangkok, 20 July 2011 (in Thai).

Apichat Satitniramai, Yukthi Mukdawijit, Niti Pawakapan, Wanwipang Manachotipong, Praphat Pintoptang, and Naruemol Thapchumpol (2010). Preliminary Report of the Project on Socio-Economic Changes of the New Emerging Class.' Research report for the Thai Health Promotion Foundation, funded by the Thai Universities for Healthy Public Policy (TUHPP), Public Policy Studies Institute (PPSI), Chiang Mai University (in Thai).

Apichat Satitniramai, Yukthi Mukdawijit, Niti Pawakapan, Wanwipang Manachotipong, Praphat Pintoptang, Viengrat Netipho, Jakrit Sangkamanee, Pinkeaw Leang-aramsri, and Anusorn Unnol (2013). 'Re-examining the Political Landscape of Thailand.' Research report for the Thai Health Promotion Foundation, funded by the Thai Universities for Healthy Public Policy (TUHPP), Public Policy Studies Institute (PPSI), Chiang Mai University (in Thai).

Crispin, S.W. (2012). Thailand's Classless Conflict. In M.J. Montesano, Pavin Chachavalpongpun, \& Aekapal Chongvilaivan (Eds.), Bangkok May 2010: Perspectives on a Divided Thailand (pp. 108-119). Singapore: ISEAS Publishing. 
Food and Agricultural Organisation of the United Nation (FAO) (2006). Rapid Growth of Selected Asian Economies: Lessons and Implication for Agricultural and Food Security, Republic of Korea, Thailand and Vietnam. Policy Assistance Series 1/3, Bangkok: FAO Regional Office for Asia and the Pacific.

Forsyth, T. (2010). Thailand's Red Shirt Protests: Popular Movement or Dangerous Street Theatre? Social Movement Studies:Journal of Social, Cultural and Political Protest, 9 (4), 461-467.

Hewison, K. (2012). Class, Inequality, and Politics. In M.J. Montesano, Pavin Chachavalpongpun, \& Aekapal Chongvilaivan (Eds.), Bangkok May 2010: Perspectives on a Divided Thailand (pp. 141-160). Singapore: ISEAS Publishing.

Hicken, A.D. (2006). Party Fabrication: Constitutional Reform and the Rise of Thai Rak Thai. Journal of East Asian Studies, 6 (3), 381-407.

Keyes, C. (2010). From Peasant to Cosmopolitan Villagers: Refiguring the 'Rural' in Northern Thailand. Special lecture organized by the Anthropology Graduate Program, Bangkok: Thammasat University, on 15th November 2010.

Kitschelt, H. (2000). Linkages between Citizens and Politicians in Democratic Polities. Comparative Political Studies, 33 (6/7), 845-879.

Naruemon Thabchumpon and McCargo (2011). Urbanized Villagers in the 2010 Thai Redshirt Protests: Not Just Poor Farmers? Asian Survey, 51 (6), 993-1018.

Nithi Eawsriwong (2008). 'The reformulation of the political system.' Matichon Raiwan, 25 August 2008, 31, 111125 (in Thai).

Nithi Eawsriwong (2010a). 'Who are the Yellow Shirts and why have they emerged?' Matichon Online, 12 July 2010 [cited 26 May 2012]. Available from http://www .matichon.co.th/news_detail.php?newsid=1278919534\&grpid\&catid=02 (in Thai).

Nithi Eawsriwong (2010b). 'Political Space that Cannot be Closed Off.' Matichon Online, 29 November 2010 [cited 26 May 2012]. Available from http://www .matichon.co.th/news_detail.php?newsid=129101680o\&grpid\&catid=02\&subcatid= 0202 (in Thai).

Pasuk Phongpaichit and Baker, C. (2012). Thailand in Trouble: Revolt of the Downtrodden or Conflict among Elites? In M.J. Montesano, Pavin Chachavalpongpun, \& Aekapal Chongvilaivan (Eds.), Bangkok May 2010: Perspectives on a Divided Thailand (pp. 214-229). Singapore: ISEAS Publishing.

Pasuk Phongpaichit and Pornthep Benyaapikul (2012). Economy of Tomorrow: A Technical Note on Thailand. Paper presented at the FES (Friedrich Ebert Stiftung) Regional Forum on the Economy of Tomorrow, 1-2 March 2010, Pullman Hotel, Bangkok: organized by FES and TDRI.

Pasuk Phongpaichit and Pornthep Benyaapikul (2013). Political Economy Dimension of a Middle Income Trap: Challenges and Opportunities for Policy Reform Thailand. In Adam Burke (Eds.), Middle Income Trap: Economic Myth, Political Reality: Case Studies from Malaysia and Thailand, Bangkok: The Asia Foundation. 
Pasuk Phongpaichit (2013). Vote-buying claims nothing but dangerous nonsense. BangkokPost, 6 Dec 2013, Retrieved from http://www.bangkokpost.com/opinion/opinion/ $383418 /$ vote-buying-claims-nothing-but-dangerous-nonsense, last accessed on Jan 16th 2014 .

Pattana Kittiarsa (2012). From Red to Red: An Auto-ethnography of Economic and political Transitions in a Notheastern Thai Village. In M.J. Montesano, Pavin Chachavalpongpun, \& Aekapal Chongvilaivan (Eds.), Bangkok May 201o: Perspectives on a Divided Thailand (pp. 230-247). Singapore: ISEAS Publishing.

Strokes, S.C. (2009). Political Clientelism. The Oxford Handbook of Comparative Politics Retrieved from http://www.oxfordhandbooks.com/search?siteToSearch=aup\&q=P olitical+Clientelism+\&searchBtn=Search\&isQuickSearch=true, last access on 3 rd March 2014.

Taylor, J. (2012). No Way forward but Back? Re-emergent Thai Falangism, Democracy, and the New "Red Shirt" Social Movement. In M.J. Montesano, Pavin Chachavalpongpun, \& Aekapal Chongvilaivan (Eds.), Bangkok May Strokes, 20og: Perspectives on a Divided Thailand (pp. 286-312). Singapore: ISEAS Publishing.

Thai Development Research Institute (TDRI) (2011). 'Report on the Life of Thais in Two Decades of Development: the Significance of Public Policy Changes on the Livelihoods of Thai Households'. Research report for the Thai Health Promotion Foundation, funded by the Thai Universities for Healthy Public Policy (TUHPP), Public Policy Studies Institute (PPSI), Chiang Mai University, September 2011 (in Thai).

Ungpakorn, G., (2009). Class struggle between the coloured T-shirts in Thailand. Journal of Asia Pacific Studies, 1(1), 76-100.

Walker, A. (2012). Thailand's Political Peasants: Power in the Modern Rural Economy. Madison: The University of Wisconsin Press. 


\section{Index}

“von Lieres" B. 243

AA Gym 183

ABIM (Angkatan Belia Islam Malaysia) 182, $185,190-194$

Abrams, P. $\quad 131$

Aburizal Bakrie 138

Aceh $179,187,198$

Africa $8,15,161,258$

Agusan del Norte 157

Agusan del Sur 157

Ahirudin Attan 221

Ahmadiyah $\quad$ 187-188

Ahmadiyahs 129

AIDS temple 257

Ambiga Sreenevasan 219

American 240, 253, 255, 259, 158, 159-160

Amina Wadud 196

Ammar Siamwalla 291-292, 294-295

Amnesty International $\quad 276$

Angkatan Belia Islam Malaysia (АВIM) 182

Anis Hidayah 281

Anwar Ibrahim 185, 190-191, 213-214, 227

Apichat Satitniramai $\quad 22,289$

Arab 'Spring' 212

Arendt, H. 4, 239

Arifin Ilham $\quad 183$

Aristotle 6

ASEAN 156, 279, 296

Aseme Gede $\quad 97,106$

Asia $\quad 9,20,22-23,158,212,244$

Asian Development Bank (ADB) 35

Asian Human Rights Commission 125

Aspinall, E. 114, 126

Assembly of the Poor $\quad 245,247$

Ati Nurbaiti 283

Austin, M. 21, 265

Aymara movements 247

Baby Nasution 279

Badan Pelindung Hak Kemanusiaan (вРнк) 106

Bagdad 142

Bakker, L. $\quad$ 18, 125, 240

Bakrie Group 138
Bali 147, 275

Balikpapan 142-145, 147

Bandung $56,59,62,97,282$

Bangkok 22, 238, 245, 248, 255, 257, 290-291, 293-295, 300-301, 305

Bangsmoro 158

Banjar 144

bantay bloke (neighbourhood watch group) 41

bantay ilog (river watch) 44

barangay $\quad 39-41,43,160-161,169$

Barangay 40

BARET 133, 135, 137-138, 144, 150

Barisan Alternatif 190

Barisan Nasional 190, 195, 211, 217, 219

Barnabas Sebilang $\quad 136$

Beijing 266

Berenschot, W. 19, 116, 240

Bersih (Coalition for Clean and Fair

Elections) 220

Bersih (Coalition for Clean and Fair

Elections) 20, 211-215, 217-225, 227-233

Bimber, B. 214

Blackburn, S. 270

blogosphere 217, 221-222

Boediono 125

Boeung Kak 80,86

Bogor 144

Bolivia 247

Borey Keila 80,86

B PHK (Badan Pelindung Hak

Kemanusiaan) 102, 107-108

Brazil 5, 17, 98, 256

Brigade Manguni $\quad 125,127-130,145^{-148,} 15^{0}$

Bristol-Myers Squibb $\quad 251,253,257$

British Empire 213

Brosius, P. $\quad 155$

Bukidnon $\quad 157$

Bun Rany 73

Bureau of Labour Export $\quad 268$

Buyers' Clubs 248

CADC (Certificate of Ancestral Domain

Claim) 168-169

Cambodia $\quad 17,68-73,75^{-7} 78,83^{-86}, 92$ 
Cambodian Citizenship Party (Konâbâk Sânheat Kampuchea) $\quad 70$

Cambodian League for the Defence and Promotion of Human Rights (LiCADHO) 84

Cambodian National Rescue Party (CNRP) 68

Cambodian People's Party (CPP) $\quad 68,72,79$

Cambodian Red Cross (CRC) 73, 87, 90, 92

CARAm Asia 280

Catholic 125,156

CENRO (City Environment and Natural Resources Office) 43

Central Intellectual Property and International Trade Court of Thailand 252

Central Java 57

Certificate of Ancestral Domain Claim (CDAC) 168

Chabal, P. $\quad 3,9,15$

Chairul Tanjung 138

Chandra, K. $\quad 126$

Chatterjee, P. $\quad 3,15,71,98,243,245^{-247}$

Chea Sim 86

Chea Sophara 89

Chiang Mai 244, 248, 255, 300

Chinese 106, 186, 190-192, 221, 228-229, 255, 275

Christian 20, 145-147, 158, 159-16o, 180

Christianity 190

Christians $\quad 145,148,186-188$

Chuan 307

Cikini 130

Cirebon 200

Citarum River 57

City Environment and Natural Resources Office (CENRO) 43

CNRP (Cambodian National Rescue Party) $68,76,79-87$

Coalition for Clean and Fair Elections (Bersih) 211, 218

Cokroaminoto Street 111

Connors, M. 78

Consultation on Planning of Annual Development Activities (MPKT) 59

Consumer Association of Penang (CAP) 193

Cornwall, A. 243

CPP (Cambodian People's Party) 68-69, 72-76, 79-87, 89-90, 93
CRC (Cambodian Red Cross) 73, 90, 93

cyberspace $\quad 215,231$

Da'i Bachtiar $\quad 265$

dakwah organizations $\quad 184$

Daloz, J. 15

DAP (Democratic Action Party) 191

Darul Arqam $\quad$ 182, 184

Darul Islam 57

datu $156,165^{-169,171-174}$

Datuk Seri Hishammuddin Hussein 221

Dayak 125, 136, 143

Dayak Customary Council of

Kalimantan 136

Democratic Action Party (DAP) 191, 229

Democrat Party 304

Depok 140-141

De Tocqueville, A. 6

Dewan Perwakilan Rakyat (DPR) 278, 28o, 282-283

digital media $\quad 212-214,217,220,228,230-231$, 233-234

Doctors without Borders $\quad 248-249,251,253$

dumagat $\quad 158-159,162-164,169,172-175$

dusun (village division) $\quad 58$

Dutch $10,54,57,134-136,148$

East Java 274

Edidani 199

Egypt 181, 212, 224, 227

Engel, D.M. $\quad 244$

Engel, J.S. 244

England 5

EU 239

Europe $7,19,180,212,257$

Euroseas 10

EU-Thai Free Trade Agreement $\quad 238$, 243, 257

Facebook $80,84,102,187,212-213,220-224$, 227-228, 232-233

Fadlulah Jamel $\quad$ 191-192, 194

Fahmina 200

Fary Malunda $\quad 127,149$

Fatayat NU $\quad 282$

Fazlur Rahman 196

Ferdinand Marcos 32

Fidel Ramos 32

Flores $\quad 125$ 
Food and Agricultural Organisation of the United Nations (FAO) 294

Forkabi 130

Formaci (Forum Mahasiswa

Ciputat) $\quad$ 196-197

Forsyth, T. $\quad 290-291$

Forum Komunikasi Putra-Putri

Purnawirawan Indonesia (FKPPI) 138

Forum Mahasiswa Ciputat (Formaci) 196

Freedom Park $\quad 68,80,87,90$

French 11, 75

Front Betawi Rempug 125, 129

Front Pembela Islam $\quad$ 125, 128-130, 147, 189

FTA Watch $\quad 255^{-257}, 259$

FUNCINPEC $\quad 68,74,89$

Garda Pemuda Nasional Demokrat (GP NasDem) 125, 132

Garut 265

Gasser, U. 231

Geneva 279

Gerakan Pemuda Asli Kalimantan (GEPAK) 125

Gibbings, S.L. $\quad$ 13, 17, 96

Gill, W. 250

Gingoog City 163

Global Bersih $\quad 228$

Global North 246, 259

Global South 71, 92, 241-243, 246, 248, 257,259

Golkar $56,58,100,134,137,138-139$, 140,187

Government Pharmaceutical Organization 250

GP NasDem (Garda Pemuda Nasional Demokrat) 125, 132-133

Green Police 44

Guevara, M. 33

Gupta, A. $\quad 98$

Habermas, J. 259

Haryanto $\quad 267$

Hary Tanoesoedibjo 138

Hatta Rajasa 102

Hefner, R. 179

Heng Samrin 86

Hercules 129

Herry Zudianto $\quad$ 96, 109

Hewison, K. 290-291
Higaunon $19,156,157,158,160,162,163,164$, $165,166,167,168-169,170,171,172,173$, 174,175

Hindman, M. 214

Hindraf (Hindu Rights Action Force) $\quad 216$

Hizbut Tahrir Indonesia (HTI) $\quad$ 188, 282

Hodgson, D. 161

Holmes, R. 33

Hong Kong 255

HTI (Hizbut Tahrir Indonesia) 184, 189, 197

Hughes, C. 78

human rights $8,70,83,141,179,185,191-192$, 199, 201, 216, 218, 220, 241-242, 244, 252, 255, 266, 271, 280

Human Rights Watch $87,104,276$

Hungary 253

Hun Sen $\quad 68,73-74,77,79,83-87$

Ibrahim 186

ICMI (Ikatan Cendekiawan Muslim Indonesia) 186

Ikatan Cendekiawan Muslim Indonesia (ICMI) 186

Ikhwanul Muslimin Indonesia $\quad 182$ ILO (International Labour

Organization) 274, 279, 281

IMF (International Monetary Fund) 19

Independence Square 219

Independent 106, 110

India $\quad 20,35,98,248,253-254$

Indian 194, 216, 221, 250

Indigenous peoples 155

Indonesia $1-2,13,15-16,18,20,22,51-54$, 65, 96-101, 104, 106-107, 116, 125-136, 139, 142, 145, 147, 150, 178-186, 188, 190-191, 197-198, 200-202, $213,243,265-270,272-278$, 281-283

Indonesian Environmental Forum (WALHI) 101

Indonesian Justice and Unity Party

(PKPI) 141

Indonesian Street Vendor Association

(APKLI) 102

Internal Security Act (ISA) 190

International Labour Organization

(ILO) 274

internet $84,212,214-216,220,227,229-230$, 233, 256 
IPSI (Islamic Propagation Society

International) $\quad$ 192-193

Iranian $\quad 213$

Islam $281,127,129,130,178,179,180,181-182$, $183,184,185,186,187-188,189,192-193$,

194, 195, 196-197, 198, 199, 200, 201, 202

Islamic Propagation Society International (IPSI) 192

Islamic state $127,181-182,186,189-192$, 195,197

Ito, T. 16

Jabatan Agama Islam Wilayah Persekutuan (JAWI) 189

Jabatan Kemajuan Islam Malaysia

(JАKIM) $\quad 189$

Jakarta xi, 21, 96, 101, 105, 129-130, 136, 141, 146-147, 269, 271-272, 277, 282

Jakarta Legal Aid Institute 101

JAKIM (Jabatan Kemajuan Islam

Malaysia) 189, 195

Jamaah Islam Malaysia (JIM) 190

Jaringan Intelektual Mudah Muhammadiyah

(JIMM) 196

Jaringan Islam Liberal (JIL) 199

Java $16,51-54,63-65,99,129,268,279$

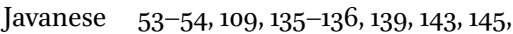
147,270

JAWI (Jabatan Agama Islam Wilayah

Persekutuan) 189, 195

Jemaah Tabligh $\quad 184$

Jenkins, H. 230

jihad 192

JIL (Jaringan Islam Liberal) 199, 202

JIM (Jemaah Islam Malaysia) 190

JIMM (Jaringan Intelektual Mudah

Muhammadiyah) $\quad 196$

John Kei 129

Johor 216

Johor Baru 224, 229

Join Action Committee for Electoral

Reform 218

Joko Widodo 22, 96, 102

Jones, C. 270

Jusuf Wanadi $\quad 267$

Kagan, J. 240

Kalimantan $\quad 271,125,129,130,139,142-143$, $144,147,148$, xi
Kamaruddin Abdullah 192

KAMм I (Kesatuan Aksi Mahasiswa Muslim Indonesia) 182, 185, 196-197

Kampuchean People's Revolutionary Party (KPRP) 68

karang taruna (youth group) $\quad 5^{8}$

Karsten, T. 99

Kartika Sari Dewi Shukarno $\quad$ 178, 201

Kartini 273-274

Kbal Thnal 80

Kelalawar Hitam $\quad 146$

Kelantan 178

Kelemen, R.D. 240

Kem Sokha 90

Kerukunan Keluarga Sulawesi Selatan (KKSS) 143

Kesatuan Aksi Mahasiswa Muslim Indonesia (KAMMI) 182

Keyes, C. $\quad$ 291, 295

Khmer Rouge $\quad 73,76-77$

Kieng Leak 89

Kitley, P. $\quad 272$

KKSS (Kerukunan Keluarga Sulawesi

Selatan) $\quad 143,148$

Klinken, G. van $\quad 126$

Kloos, D. 19

Komando Pertahanan Adat Dayak Kalimantan (KPADK) 125, 136

Kompas-Gramedia Group $\quad 267$

KPRP (Kampuchean People's

Revolutionary Party) 68

Kuala Lumpur $\quad 219,223-224,227,229,265$, 280

Kuncen 96-97, 110-111, 115

Kutai 144

Kyai Hussein Muhammed 200

La Galigo $\quad 143,147$

Laguna Lake $\quad 42$

Lanao del Norte $\quad 157$

Laskar Jihad $\quad 145^{-146}$

Legal Aid Institute 274

Leiden 10

Lembaga Ombudsman Daerah (LOD) 113

Lev, D. 12

Lim Kit Siang 221

Lim, M. 20, 211, 222

Lina Joy 190

Lindquist, J. $\quad 269$ 
Liow, J.C. $\quad$ 190, 195, 201

Lister, R. $\quad 266-267,283$

Lombok $\quad 269$

Lopburi 258

Lumad $\quad 157-158,164,166-167$

Lund, C. $\quad 16,71,93,99$

Luzon 157

Maengkom 146

Mahasarakham Province 295

Mahathir 213

Mahathir Mohamed $\quad 1,85,189,192-193,215$, 218, 227-228

Mahmood, S. $\quad 180$

Majalaya $\quad 57,59,62$

Majelis Ulama Indonesia (MUI) $\quad 185,187$

Makassar 142, 147

Makati 35

Malay $182,186,189,191,194-195,202,211$, $213-214,217,221$

Malays $178,189-190,192-195,202,217$, 229, 233

Malaysia $\quad 1,11,19-20,85,101,178-186$,

189-192, 194-195, 200-202, 211-217,

219-222, 228-229, 231, 265-269, $271-281,283$

Malioboro Street 102

Mandaluyong 33-35, 37-39, 47

Mangkubumi Street $\quad$ 105-106, 109, 111-115

Manila $\quad 33-37,42,47,161-162$

Margolis, M. 214

Marshall, T.S. 5

Masaai $\quad 161$

Mataram 54

McCargo, D. $\quad 156$

McKenna, T. 163

Mecca 186

Media Indonesia Group 138

Megawati Soekarnoputri 271

Melanesia 166

Merdeka Heritage Trust 223

Merdeka Stadium 223

Merry, S.E. 242

Metro Manila Development Authority (MMDA) 34

Metro TV 138

Mexico 247

Middle East 181, 212

Migrant Care $\quad 274$, 276, 280-281
Migrant Workers Placement and Protection

Agency 274

Minahasa $\quad x i, 129,145^{-146,148}$

Mindanao $\quad$ 156-159, 161, 163-164, 175

Ministry for Women's Empowerment 271,282

Ministry of Manpower and

Transmigration 268

Ministry of Public Health $\quad 251$

Misamis Oriental 157

mitra cai (irrigation association) $\quad 5^{8}$

MMDA (Metro Manila Development

Authority) 34

Modesta Rangga 274

Mohamed 'Cikgu' Azmi Abdul Hamid 193

Moluccas 145

Monas (Monumen Nasional) 132

Monkhol na Sonkhla $\quad 256$

Monumen Nasional (Monas) $\quad 132$

Moore, B. 20

Moros 157-159

MPR (Majelis Perwakilan Rakyat) 125, 132

Mueang District 295

Muhammadiyah $\quad 184,196,199$

MUI (Majelis Ulama Indonesia) 282, 187-188

Multimedia Super Corridor (MSC) 215

Munger, F. 244-245, 247

Muslim Brotherhood 181-182

Muslims $282,129,130,146,178,179,180$, 181-182, 183, 187-188, 189, 194, 197, 202

Myanmar 20

Nahdlatul Ulama (NU) $\quad$ 184-185, 282

Najib Razak 189, 219, 227

Napindan Channel $\quad 42$

Naruemon Thabchumpon 291

Nasr Abu Zayd 196

National Access to Antiretroviral Programmes for People living with HIV/AIDS 250

National Commission on Indigenous Peoples (NCIP) 159-160

National Democrats $125,137-138,144,150$

National Union of Malaysian Muslim

Students 191

NCIP (National Commission on Indigenous Peoples) 159, 169-170

Neuman, W.R. $\quad 214$

Newmont Mining Corporation $\quad 146$ 
New Order $22,269,280,55,56,58,63,98$, $99,101,103,104,115,116,126,127,133$, $134,135,137,138-139,148,149,150,185$, 186,188

New Zealand 142

Nguyen, V. $\quad 258$

Nithi Eawsriwong 292

Nong Tuen 295

Norén-Nilsson, A. 16

Norodom Marie 73

Norodom Ranariddh $\quad 73-75,89$

Norodom Sihanouk 75

North America 212

NU (Nahdlatul Ulama) 199

Nurul Wijayanti 274

Occident 7

Occupy Movement 212

Occupy Wall Street $\quad 218$

Ombudsman 111-112

Ong, A. 22

Ong Hok Ham 54

Ooi, J. 221

Oppenheimer, J. $\quad 141$

organisasi kemasyarakatan (ormas) $\quad 18,127$

Orient 7

ormas (organisasi kemasyarakatan) 18

ormas (organisasi kemasyarakatan)

127-128, 131, 133, 135, 137, 143-144,

$147^{-150}$

ormas (organisasi kemasyarakatan) 129-131

O'Russey market $\quad 68,89-91$

O'Shaughnessy, K. $\quad 269$

Padang 104

Pahang $\quad 178$

Pahang Syariah High Court $\quad 178$

Pakatan Rakyat 190, 211, 220, 229

Palfrey, J. 231

Pancasila 100, 125, 127, 129, 131-144, 148, 197

Paredes, O. 19, 155

Partai Keadilan Sejahtera (PKS) 182

Partai Nasional Demokrat 132

Partai Patriot Pancasila 139

Partai Persatuan Pembangunan (PPP) 186

Parti Islam seMalaysia (PAS) $\quad 182$

Parti Keadilan Rakyat (PKR) 191

PAS 182

Pasig $\quad 33-35,42,45^{-47}$
Pasig $\mathrm{C}_{3}$ (Pasig Command, Communications and Control Centre) 43

Pasig Command, Communications and Control Centre (Pasig C3) 43

Pasig Green City Programme 42, 45

Pasig River Rehabilitation Commission 44 PAS (Parti Islam seMalaysia) $178,182,186$, 189-190, 192-193, 195, 216, 229

PAS (Parti Islam seMalaysia) $\quad 185$

Pasuk Phongpaichit 307

Pattana Kittiarsa 291

Pattaya 248

Pawanteh, L. 230

Pedagang Klithikan Mangkubumi 96

Peletz, M. $\quad 189$

Pemuda Pancasila $100,125,129-130,134,137$, 139-144, 146, 150

Penang 191-192, 194-195, 216, 224, 229

People Power Party (PPP) 304

People Power Revolution 32

People's Alliance for Democracy (PAD) $\quad 255$, 289

People's Democratic Reform Committee 290

People's Republic of Kampuchea 74

People's Socialist Community 75

Pergerakan Pemuda Indonesia untuk

Perubahan (PPIP) $\quad 106$

Perlis $\quad 178$

Permesta Rebellion 145

Persatuan Pedagang Pinggir Jalan Yogyakarta

(PPJ-Y) $\quad 100$

Persatuan Ulama Malaysia $\quad 185$

Persiba $\quad$ 142-143

Pethikbumi 96, 97, 98, 106-108, 109, 110, $111-112,113,114,115,116$

Phay Siphan 88

Pheu Thai 307

Philippines $1,15^{-16}, 19-20,31-32,42,46,48$, $155^{-15} 8,160,213,268,275$

Phnom Penh $\quad 68,80,85^{-92}$

PKK (family welfare group) 58, 282

PKS (Partai Keadilan Sejahtera) 182, 185, 189,197

PLHA 243

PLHA (People Living with HIV and AIDS) 238-239, 247-248, 250-255, 258-259

PLHA(People Living with HIV and AIDS) 249

Pochentong Airport 68 
Porio, E. $\quad 16,31-32,34,160$

Poso 146

PPIP (Pergerakan Pemuda Indonesia untuk

Perubahan) 106-108

PPP (Partai Persatuan Pembangunan) 186

Prabowo Subianto 22

Pramesh Chandran $\quad 216$

preman groups 134

Priangan 57

Prim Haryadi 140

Purahong 248

Quezon City 34

Radio Free Asia $\quad 87-88$

Rahima 199

Rahim, S.A. 230

Rajadamdern Road 238

Raja Petra Kamaruddin $\quad 215$

Rayong 248

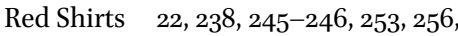
289-292, 295, 299-301, 308-309

Reformasi $51,56,59-60,65,97-98,107,116$, 149, 190-191, 213-214, 216, 219

RELA $\quad 269$

Resnick, D. 214

Rieke Pitaloka 280

Robinson, K. $\quad 269-270$

Robins, S. $\quad 242-243,245^{-247}, 25^{8}$

Robison, R. $\quad 54-55$

Roman 5

Rosaldo, R. 19, 157, 175

Royal Malaysia Police (Polis Diraja

Malaysia) 225

Rudi Samin $\quad$ 140, 144-145, 150

Sabah 147, 229

Sahlins, M. $\quad 166$

Samak Sundaravej 304

Samarinda 130

Sam Rainsy $\quad 68,76-77,91,93$

San Juan City 34

Sarawak 229

Saudi Arabia $\quad$ 275, 279, 281

Sayyid Abdul A'La Maududi 192

Schaffar, W. 17, 21, 71, 309

Schulte Nordholt, H. 116, 126, 240

Scott, J. 11, 217

Selangor 178
Shah 213

Shi'a $\quad 187-188$

Sibbitt, E.C. $\quad 240$

Siegel, J. 135

Silvey, R. $\quad 275$

Simandjuntak, D. 102

Singapore 85

SIS (Sisters in Islam) 200

Sisters in Islam (SIS) 200

Siti Hajar $\quad 265^{-266}, 272,274$

Smith, I 240

Soekarno 125-126, 131

Solidaritas Perempuan $\quad 271,280$

Somchai Jitsuchon 291-292

Somchai Phatharathananunth 247

Somchai Wongsawat 304

South Africa $\quad 239,241,252-253,258$

Southeast Asia $\quad 1-2,4,8-12,14-15,17,19-20$, 23, 116, 155-157, 159, 175, 185, 195, 197, 201, 212, 243, 266, 290

Southern Square 106

South Sulawesi 104, 143

Spanish $158,160,218$

Spivak, G. $\quad 175$

Sripen, T. 250

Stadium Negara 223

Steung Meanchey 80

Steven Gan 216

Stokes, S.C. 306

Straits of Malacca 191

Sufi 183,185

Suharto $55-56,98-100,106-107,111$, 115-116, 126, 128, 131, 134, 139,

$145,181,185^{-186,213, ~ 243, ~}$

$271-272,280$

Sulawesi $\quad 145^{-147}$

Sultan of Pahang 178

Sultan of Perak 215

Sulu 147

Sumasri 274

Sumatra 145

Surya Paloh $\quad$ 132-133, 137, 144

Susilo Bambang Yudhoyono $\quad$ 102, 278

Syahrir Taher 142-143, 145

Syed Abdullah Syed Hussein

al-Attas $\quad 216$

Taman Ismail Marzuki $\quad 280$

Tamil $\quad 221$ 
Tanod Sapa (creek security) 44

tarbiyah movement $\quad$ 181-184, 196

Taylor, J. $\quad 290-291$

Tenaganita 280

Teras Pengupayaan Malayu 193

Terengganu 178

Thailand $\quad 1,20-22,71-72,78,238-239$, 243-251, 253-259, 289-294, 296-298, 305-306, 308, 310

Thai Network of People Living With HIV and AIDS (TNP+) 243, 247-248

Thai Rak Thai 290, 293, 299, 301, 303, 307

Thaksin Shinawatra $\quad 238,245^{-246}, 249$, 254-256, 289, 299, 302-304, 306-307

Thonburi 300

Tilly, C. $\quad 5,240$

TNP+ (Thai Network of People Living With HIV and AIDS) 243, 247-249, 254-259

Tri Dharma 100

Turner, B. $\quad 180$

Twitter 102, 212-213, 220-221, 224-225, 227, 232-233

Typhoon Ketsana 43

UDD (United Front for Democracy against

Dictatorship) $\quad 289$

Ukraine 253

Ulil Absar Abdalla 199

UMNO (United Malays National

Organisation) 178, 186, 189-190, 192, 195,217

Ungpakorn, G. $\quad$ 290-291

United Arab Emirates 271

United Front for Democracy against

Dictatorship (UDD) $\quad 289$

United Kingdom $\quad 268$

United Malays National Organisation (UMNO) 178

United Nations Development Programme (UNDP) 241
United States of America $\quad$ 19, 212-213, 251, 253-254, 259, 268

University of Malaya Medical Centre 265 UN (United Nations) 35

Urban Poor Affairs Office (UPAO) 37

US-Thai Free Trade Agreement 255

Vietnam 11

Walker, A. $\quad$ 71, 83, 246, 291

Wan Azizah Wan Ismail 191

Wanwiphand 292

Wat Prahbat Namphu 257

Weber, M. $\quad$ 7, 131, 149

Weiss, M. 114, 219, 275

Welfareville $\quad 34-35,37,39-41$

Western $3,6,7,8,14,16,18,19,239,242,245$, $246,247,255,258,259,268,71,77,116$, 128, 180, 192-193, 196, 199, 201, 202, 224

West Java $\quad 57,97,140,265$

WH (Wilayatul Hisbah) 198

Wichelen, S. $\quad 272$

Wilayatul Hisbah (WH) 198

Wilson, I. 134, 136, 139

Winters, J. 2

Wiranto 137

World Bank 19, 35, 59, 217, 248, 268, 293

World Health Organisation 248

World Trade Organisation $\quad 251^{-252,254-255}$

Yapto Soerjosoemarno $\quad$ 138-139

Yazid, S. 270

Yellow Shirts $\quad 22,238,245^{-246}, 253^{-254}$, 289-293, 304-305, 308-309

Yogyakarta 96-97, 100-101, 104-107, 114

Yorrys Raweyai $\quad$ 139-140

YouTube 212

Zapatista movement $\quad 247$

Zudianto $\quad 112$ 